UNIVERSIDADE DE SÃO PAULO

FACULDADE DE FILOSOFIA, LETRAS E CIÊNCIAS HUMANAS

DEPARTAMENTO DE HISTÓRIA

PROGRAMA DE PÓS-GRADUAÇÃO EM HISTÓRIA SOCIAL

\title{
AS MARCAS DA LIBERDADE: \\ trajetórias sociais dos libertos em Mariana na segunda metade do século XVIII
}

RENATA ROMUALDO DIÓRIO

SÃO PAULO

2007 
UNIVERSIDADE DE SÃO PAULO

FACULDADE DE FILOSOFIA, LETRAS E CIÊNCIAS HUMANAS

DEPARTAMENTO DE HISTÓRIA

PROGRAMA DE PÓS-GRADUAÇÃO EM HISTÓRIA SOCIAL

\section{AS MARCAS DA LIBERDADE: \\ trajetórias sociais dos libertos em Mariana na segunda metade do século XVIII}

RENATA ROMUALDO DIÓRIO

Dissertação apresentada ao Programa de PósGraduação em História Social do Departamento de História da Faculdade de Filosofia, Letras e Ciências Humanas da Universidade de São Paulo, para a obtenção do título de Mestre em História.

Orientador: Prof. Dr. Rafael de Bivar Marquese

SÃO PAULO 
Aos meus pais, Milton e Maria do Carmo Diório. 


\section{AGRADECIMENTOS}

Ao meu orientador Rafael de Bivar Marquese, pelo apoio e valiosas sugestões no desenvolvimento deste trabalho.

Aos membros da minha banca de qualificação, professores Carlos Almeida Prado Bacellar e Maria Cristina Cortez Wissenbach, por suas leituras generosas e importantes contribuições.

Ao professor Renato Pinto Venâncio, incentivador deste e de tantos outros trabalhos iniciados em suas disciplinas ministradas no ICHS/UFOP.

Às funcionárias do Arquivo Eclesiástico da Arquidiocese de Mariana: Luciana, Adelma e Fabiana. Ao Cássio, Antero e Cida, pela assistência e momentos agradáveis durante a consulta aos documentos do acervo da Casa Setecentista de Mariana. À Maria Teresa Pereira e Maria José Ferro, pesquisadoras mineiras extremamente solícitas em suas informações sobre técnicas de pesquisa e os arquivos de Mariana. Ao Estêvam Costa Martins, no auxílio à pesquisa das fontes.

À minha família, pelo constante incentivo. Meus queridos pais, Milton e Maria do Carmo, que me apoiaram desde o início, quando a idéia da minha mudança para São Paulo ainda lhes causava estranheza. Meus irmãos Arlindo e Milton, pelo auxílio, conselhos e grande estímulo em momentos críticos. Agradeço também às minhas irmãs Patrícia e Cristina, minhas tias Ana e Terezinha, e minha querida avó Juraci Brandão Romualdo, por suas manifestações de carinho.

À família Brandão, que me acolheu em São Paulo nos primeiros momentos do mestrado.

Aos amigos especiais e colegas que aqui conheci e com os quais pude conviver: Clairton Rosado, Geórgia Prado, Érika Cavalcanti, Vanicléia da Silva Santos, Daniel Afonso da Silva, Elenita Martins (Kika) e Cícero João. Ao colega de graduação e também companheiro de mestrado, Aldair Carlos Rodrigues.

Ao querido amigo marianense, Moacir Rodrigo de Castro Maia, pelas longas conversas e grande estímulo.

Ao Paulo Costa Sobrinho, pelo companheirismo, incentivo e momentos especiais. 
À Fapesp, que viabilizou a realização deste trabalho por meio de seu importante apoio financeiro. 


\section{SUMÁRIO}

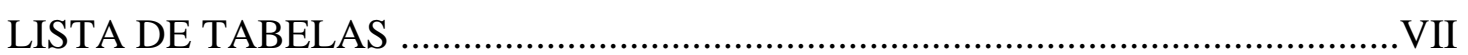

LISTA DE GRÁFICOS .....................................................................................

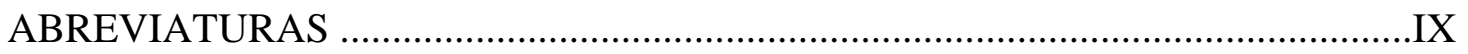

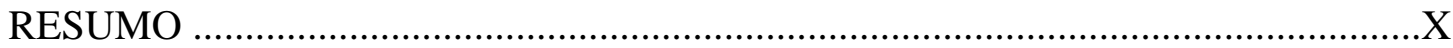

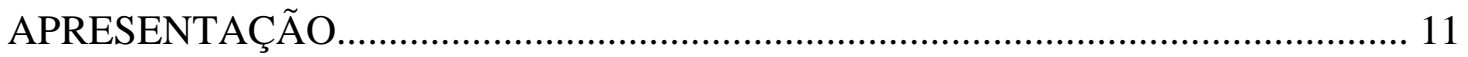

CAPÍTULO 1 - Escravidão, alforria e libertos em Mariana .......................................... 16

1.1. A geografia política de Mariana ……………………...................................... 16

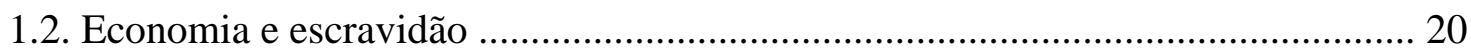

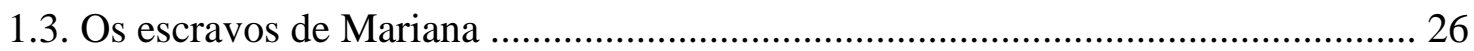

1.4. Tipos de alforria e estimativas da população …………………………………….... 31

1.5. Traços sobre a procedência da população liberta .................................................... 41

CAPÍTULO 2 - Sobrevivendo forro: indícios de pobreza e de propriedade .................. 48

2.1. O liberto na sociedade colonial .......................................................................... 48

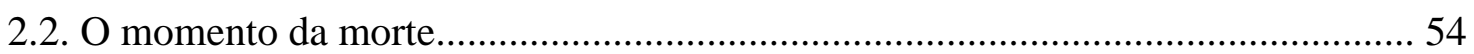

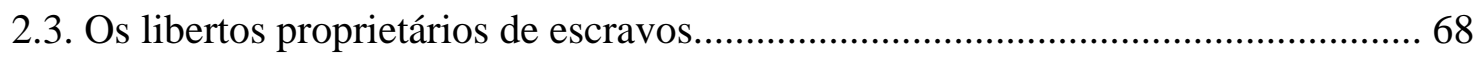

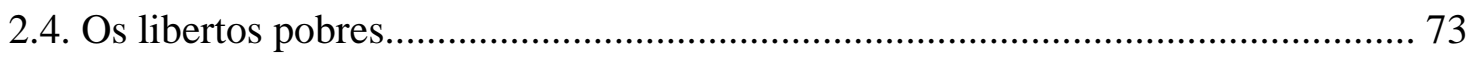

CAPÍTULO 3 - Endividamento dos libertos na Mariana colonial.................................. 86

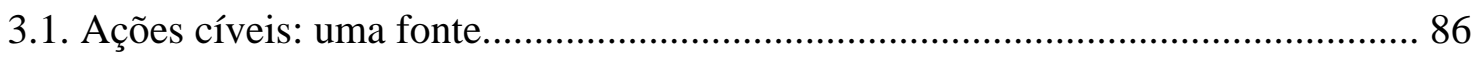

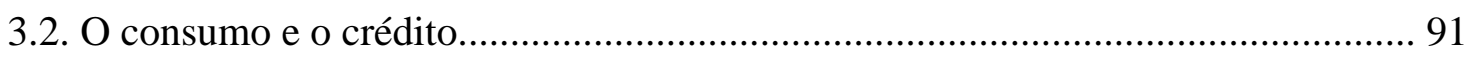

3.3. Despesas com a própria subsistência.................................................................... 98

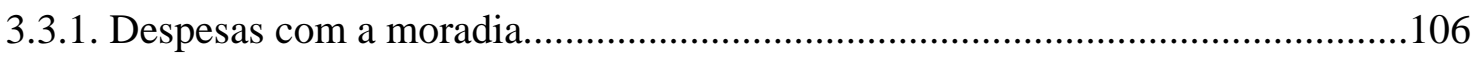

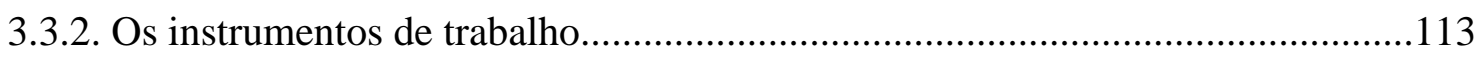

3.4. Outras dimensões para os negócios..................................................................116

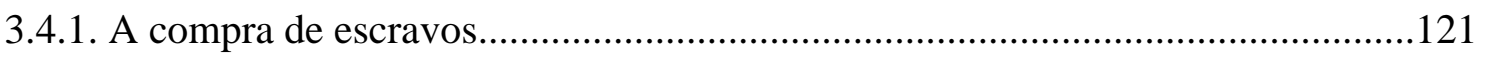

3.4.2. Negócios com o gado e com a terra................................................................132

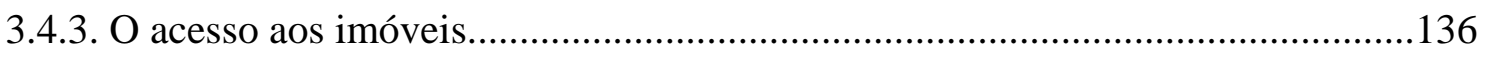

CAPÍTULO 4 - Forros: uma condição social instável....................................................144

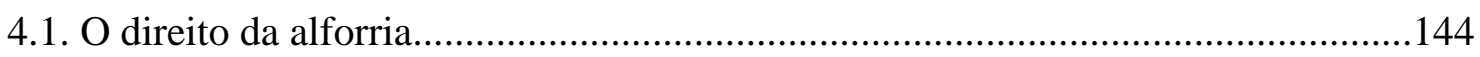

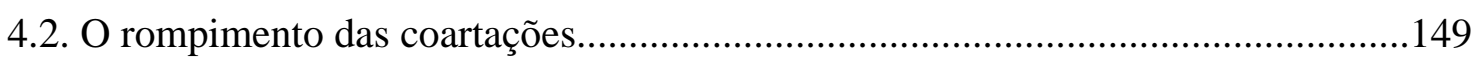




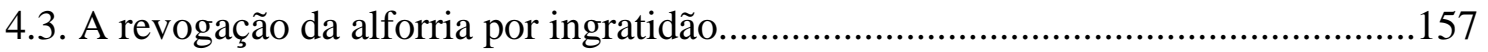

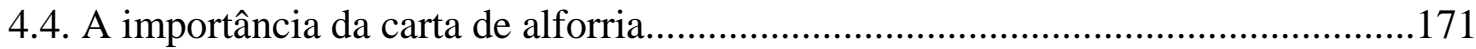

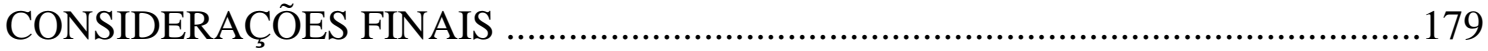

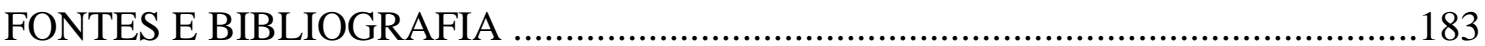




\section{LISTA DE TABELAS}

Tabela 1 - População Escrava em Mariana, 1717-1808 29

Tabela 2 - Alforrias em Mariana (1735-1740) e (1771-1775) ...........................................34

Tabela 3 - Alforrias gratuitas e condicionais em Mariana (1735-1740) e (1771-1775) ....38

Tabela 4 - Número de óbitos ocorridos em Mariana, 1751 a 1800 ...................................55

Tabela 5. Estado civil dos libertos falecidos em Mariana, 1751-1800 ..............................63

Tabela 6 - Óbitos de libertos pobres e registros que não especificavam nenhuma condição, 1751-1800 .66

Tabela 7 - Indicação da condição senhorial nos óbitos de escravos de Mariana, 1751 a 1800

Tabela 8 - Número de óbitos de libertos pobres em Mariana, 1751 a 1800 81 


\section{LISTA DE GRÁFICOS}

Gráfico 1 - População escrava de Minas Gerais, 1735-1749 . .27

Gráfico 2 - População escrava em Mariana .30 


\section{ABREVIATURAS}

ACSM - Arquivo da Casa Setecentista de Mariana

AEAM - Arquivo Eclesiástico da Arquidiocese de Mariana

AHCMM - Arquivo Histórico da Câmara Municipal de Mariana

AHU - Arquivo Histórico Ultramarino 


\title{
RESUMO
}

A dissertação analisa a trajetória social dos libertos de Mariana (MG) na segunda metade do século XVIII, período caracterizado pela reorganização da economia local, após o auge da mineração. Ao longo do século formou-se, naquela sociedade, um contingente significativo de egressos do cativeiro. O trabalho procura demonstrar, por meio do exame de diversos repertórios documentais (registros de óbitos, testamentos, inventários e ações cíveis), que o aspecto central daquelas trajetórias sociais foi a obtenção da liberdade. Ainda que a maior parte desses libertos contraísse dívidas e morresse na pobreza, a alforria representava o ponto de inflexão decisivo em suas vidas.

Palavras-chave: Alforria, Libertos, Trajetória social, Pobreza, Século XVIII.

\begin{abstract}
This work analyses the social trajectory of the freedmen in Mariana (MG) in the second half of the eighteenth century, a period characterized by the reorganization of the local economy, after the mining peak. Throughout the century, a significant contingent of people released from captivity was formed in that society. This work aims at demonstrating, through the exam of several documents, death records, testaments, inventories e civil actions, that the central aspect of such social trajectories was the conquest of freedom. Although most of the freedmen obtained debts and died in poverty, the manumission represented the turning point in their lives.
\end{abstract}

Key-words: Manumission, Freedmen, Social trajectory, Poverty, $18^{\text {th }}$ Century. 


\section{APRESENTAÇÃO}

Os primeiros contatos com fontes setecentistas sobre os egressos do cativeiro na cidade de Mariana, realizados ainda durante a graduação, despertaram surpresas e estimularam o interesse pela pesquisa de suas trajetórias sociais. ${ }^{1}$ A intenção inicial era compreender o que se pensava ser a história de um grupo reduzido de escravos que chegaram a conquistar a liberdade e puderam reestruturar suas vidas. Ao longo do levantamento de dados, percebemos que esse conjunto não era tão restrito, e que as ações que permearam suas experiências cotidianas, por vezes fortuitas e instigantes, indicavam algumas das marcas da liberdade na sociedade marianense setecentista.

O ponto de partida para a investigação desse objeto foram os trabalhos sobre as alforrias no Brasil e, de maneira especial, em Minas Gerais. Percebemos que, até a década de 1970, pouco se escreveu sobre o tema; a partir desse período, surgiram pesquisas voltadas à compreensão dessa prática e seus desdobramentos. Os estudos atualmente disponíveis abrangem regiões diversificadas e contemplam os períodos colonial e imperial, mas há predominância para as décadas posteriores à Independência e os anos que antecederam a abolição. Basicamente tiveram como objetivo verificar a incidência de concessões, o perfil do escravo alforriado e, principalmente, as formas encontradas para adquiri-las. Os resultados desses trabalhos abriram discussões sobre os motivos que impulsionavam a prática da manumissão, bem como reflexões acerca da relação entre senhores e escravos e do papel desempenhado pelos últimos na conquista da liberdade. De maneira geral, essas pesquisas mostraram que houve no Brasil uma difusão das manumissões, que, por sua vez, acabou gerando um significativo contingente de egressos do cativeiro durante a vigência do regime escravista.

As primeiras menções feitas pela historiografia sobre os egressos do cativeiro antecederam os estudos a respeito das manumissões. Caio Prado Júnior, por exemplo, propôs em 1942 que a sociedade colonial era composta por dois grupos, um de senhores e outro de escravos. Os primeiros representavam uma minoria de dirigentes coloniais, enquanto os últimos compunham a grande massa de trabalhadores. Para além deste segmento, orgânico em

\footnotetext{
${ }^{1}$ A pesquisa de Iniciação Científica, intitulada “A ambígua liberdade: riqueza e pobreza entre os libertos de Mariana, 1750-1800”, orientada pelo Prof. Dr. Renato Pinto Venâncio (ICHS/UFOP), foi realizada com auxílio financeiro da Fundação de Amparo à Pesquisa do Estado de Minas Gerais - FAPEMIG (Código do Processo: SHA 85068/01) - e desenvolvida entre os meses de março de 2002 e fevereiro de 2003.
} 
seu antagonismo, haveria um grupo crescente de indivíduos que formavam uma subcategoria, denominada como "inorgânica” e onde se inseriam, dentre outros, os pretos e mulatos forros. ${ }^{2}$

A linha interpretativa inaugurada por Prado Jr. encontrou desdobramentos nas décadas seguintes, sendo seguida por pesquisadores importantes até o presente momento. Geralmente baseados em fontes de natureza administrativa, tendem a definir os libertos como uma categoria crescente de pessoas desclassificadas e temidas socialmente. ${ }^{3}$ Segundo essa vertente historiográfica, foram criadas políticas de controle das manumisões, bem como de absorção dessa população, com o objetivo de mediar possíveis conflitos sociais. Esses sujeitos foram recrutados para executar funções a cargo do Estado, como os corpos paramilitares, ${ }^{4}$ mas também estiveram sob controle das autoridades eclesiásticas na medida em que se inseriam nas irmandades, corporações de práticas religiosas definidas pelo catolicismo. ${ }^{5}$

Estudos mais recentes, contudo, defendem que tais agrupamentos tendiam a consagrar as identidades africanas criadas a partir da diáspora, unindo povos na América Portuguesa, que, por vezes, eram separados cultural e geograficamente em seu território de origem, a África. ${ }^{6}$ Dessa forma, serviam como espaços cotidianos coletivos dos interesses dos homens de cor e permitiam a sua integração na sociedade.

\footnotetext{
${ }^{2}$ PRADO JÚNIOR, Caio. Formação do Brasil contemporâneo. 13ª ed. São Paulo: Brasiliense, 1973, p. 281-286.

${ }^{3}$ SOUZA, Laura de Mello e. Desclassificados do ouro: a pobreza mineira no século XVIII. Rio de Janeiro: Graal, 1982. Em prefácio à nova edição do livro, revista e ampliada, a autora arrola uma série de trabalhos acadêmicos e publicações que seguiram a perspectiva analítica por ela proposta. Ver SOUZA, Laura de Mello e. Desclassificados do ouro. A pobreza mineira no século XVIII. $4^{\text {a }}$ edição revista e ampliada. Rio de Janeiro: Graal, 2004, p.9-15. Ver também: RIBEIRO, Núbia Braga. Cotidiano e liberdade: um estudo sobre os alforriados em Minas no século XVIII. Dissertação de Mestrado, FFLCH/USP, São Paulo, 1996; LARA, Sílvia Hunold. Fragmentos setecentistas: escravidão cultura e poder na América Portuguesa. Tese de Livre-Docência, IFCH/Unicamp, Campinas, 2004.

${ }^{4}$ As atividades destacadas por Laura de Mello e Souza foram: "constituição dos corpos que se aventuravam pelo sertão em entradas; a guarda, defesa e manutenção dos presídios; o trabalho nas obras públicas e na lavoura de subsistência; a formação de corpos de guarda e polícia; a composição de corpos de milícia e de outros recrutados esporadicamente para fins diversos; a abertura e povoamento de novas áreas, as fronteiras". SOUZA, Desclasificados do ouro, p.74; LARA, Fragmentos setecentistas, p. 333; SILVA, Luiz Geraldo. "Da festa à sedição. Sociabilidades, etnia e controle social na América Portuguesa (1776-1814)". In: JANCSÓ, István; KANTOR, Íris (orgs.). Festa: Cultura \& Sociabilidade na América Portuguesa. São Paulo: Hucitec: Editora da Universidade de São Paulo: Fapesp: Imprensa Oficial, volume I, 2001, p.313-335.

${ }^{5}$ Ver, a respeito, os trabalhos de: BOSCHI, Caio César. Os leigos e o poder. Irmandades leigas e política colonizadora em Minas Gerais. São Paulo: Ática, 1986. SCARANO, Julita. Devoção e escravidão. A Irmandade de Nossa Senhora do Rosário dos Pretos no Distrito Diamantino no século XVIII. São Paulo: Nacional-Coleção Brasiliana, 1976. AGUIAR, Marcos Magalhães de. Vila Rica dos Confrades: A sociabilidade confrarial entre negros e mulatos do século XVIII. Dissertação de Mestrado, Universidade de São Paulo, 1993.

${ }^{6}$ REIS, João José. Identidade e diversidade étnicas nas irmandades negras no tempo da escravidão. Tempo, vol. 2, nº3, 1996, p.11. BORGES, Célia Maia. Escravos e libertos nas Irmandades do Rosário: devoção e solidariedade em Minas Gerais, séculos XVIII e XIX. Juiz de Fora: Editora da UFJF, 2005. SILVA, "Da festa à sedição", SOARES, Mariza de Carvalho. "Descobrindo a Guiné no Brasil colonial”. RIHGB, Rio de Janeiro, 161(407) 71-94, abr./jun. 2000. SOARES, Mariza de Carvalho. "A 'nação' que se tem e a 'terra' de onde se vem: categorias de inserção social de africanos no Império português, século XVIII”. Estudos Afro-Asiáticos, Ano 26, n²6, 2004. PINHEIRO, Fernanda Aparecida Domingos Pinheiro. Confrades do Rosário: sociabilidade
} 
Os trabalhos sobre os libertos também abordaram suas condições econômicas. Por um lado, foram associados à marginalidade e à condição de pobreza ${ }^{7}$, por outro, foram vistos como sujeitos ativos que, a partir da errância, buscaram encontrar alguma ocupação que viabilizasse a sobrevivência e acúmulo de posses. ${ }^{8}$ Com a investigação de características da vida material, outros pontos foram apresentados como a importância das relações familiares, as crenças e, principalmente, atitudes tomadas diante da morte iminente. ${ }^{9}$

Nas duas últimas décadas, as pesquisas deram maior destaque ao papel econômico das mulheres forras na sociedade, talvez por serem mais representativas nos corpus documentais examinados. ${ }^{10}$ Essas investigações priorizaram a análise das posses arroladas em testamentos ou em inventários post-mortem, e elucidaram a possibilidade de ascensão econômica e social. Foi possível perceber que as libertas adquiriram objetos de valor como escravos, imóveis e jóias, mas também tiveram apreço por artigos mais sofisticados de uso cotidiano, no que adotaram costumes da classe dominante da sociedade na qual se inseriram. ${ }^{11}$

e identidade étnica em Mariana - Minas Gerais (1745-1820). Niterói: ICHF/UFF, Dissertação de Mestrado, 2006.

${ }^{7}$ SOUZA. Desclassificados do ouro, p.144.

${ }^{8}$ Ao analisa "os andarilhos da sobrevivência", Sheila de Castro Faria constatou que a maior parte da população pobre que tendia a se movimentar em busca de melhores condições de vida, constituía de pessoas originadas do sistema escravista ou de seus descendentes. FARIA, Sheila de Castro. "Histórias esquecidas: Os andarilhos da sobrevivência”. In: A colônia em movimento: fortuna e família no cotidiano colonial. Rio de Janeiro: Nova Fronteira, p. 101-162.

${ }^{9}$ LEWCOWICZ, Ida. "Herança e relações familiares: os pretos forros nas Minas Gerais do século XVIII". Revista Brasileira de História. V. 9, n ${ }^{\circ} 17$, set.88/fev.89, p. 101-114; OLIVEIRA, Maria Inês Cortes de. O liberto: o seu mundo e os outros, Salvador, 1790-1890. São Paulo: Corrupio, 1988. Em trabalho posterior, a autora verificou como a reconstrução das identidades étnicas foi fundamental para a dinâmica dos africanos na sociedade, redefinindo relações familiares, de parentesco ou laços de afinidade. OLIVEIRA, Maria Inês Côrtes de. "Viver e morrer no meio dos seus. Nações e comunidades africanas na Bahia do século XIX". Revista USP, São Paulo (28), dez/fev. 95/96, p. 176.

${ }^{10}$ PAIVA, Eduardo França. Escravidão e universo cultural na colônia - 1716-1789. Belo Horizonte: UFMG, 2001; FARIA, Sheila de Castro. "Mulheres forras - riqueza e estigma social". Tempo, Rio de Janeiro, 2001, n⿳9, p. 65-92; FARIA, Sheila de Castro. "Sinhás pretas: acumulação de pecúlio e transmissão de bens de mulheres forras no sudeste escravista (séc. XVIII-XIX)”. In: FRAGOSO, João (Org.). Escrito sobre História e Educação: uma homenagem a Maria Ieda Linhares. Rio de Janeiro: Mauad/SAPERJ, 2001, p.289-329; LARA, Sílvia Hunold. "Sedas, panos e balangandãs: o traje de senhoras e escravas nas cidades do Rio de Janeiro e de Salvador (século XVIII)”. In: SILVA, Maria Beatriz Nizza da (Org). Brasil: colonização e escravidão. Rio de Janeiro: Nova Fronteira, 2000, p. 177-191; MÓL, Claudia Cristina. Mulheres forras: cotidiano e cultura material em Vila Rica (1750-1800). Dissertação de Mestrado, FAFICH/UFMG, Belo Horizonte, 2002; MÓL, Cláudia Cristina. "Entre sedas e baetas: o vestuário das mulheres alforriadas em Vila Rica". Varia História, n³2, julho, 2004, p.176-189; FURTADO, Júnia Ferreira. Chica da Silva e o contratador de diamantes. O outro lado do mito. São Paulo: Companhia das Letras, 2003; FARIA, Sinhás Pretas, Damas Mercadoras. As pretas minas nas cidades do Rio de Janeiro e de São João Del Rey (1700-1850). Tese apresentada ao Departamento de História da Universidade Federal Fluminense, Concurso para Professor Titular em História do Brasil, Niterói, 2004.

${ }^{11}$ Articulando ainda com a idéia de que a população liberta era temida pela sociedade, e, sobretudo, pela classe dominante, em artigo porterior, Eduardo França Paiva concluiu que "não foi o fato de burlarem a lei que os transformava em indivíduos indesejáveis, mas ao contrário, era o fato de ascenderem economicamente e de conquistarem certo status social, sem que ao menos infringissem as leis e os costumes vigentes”. PAIVA, Eduardo França. Libertos no Brasil: africanos e mestiços nas Minas Gerais do século XVIII. Disponível em: http://geocities.yahoo.com.br/silvanifanni/EduardoFPaiva-TextoLibertosnoBrasil.pdf, p. 1. 
Em que pesem seus méritos, essas pesquisas tendem a se restringir a dois aspectos específicos e antagônicos: a vida em pobreza (com a conseqüente desclassificação social) ou a ascensão econômica. Enquanto a primeira vertente faz, em geral, uma leitura desses sujeitos a partir da documentação administrativa, adotando, por vezes, a visão da elite dominante da colônia, a segunda tende a se restringir a um grupo específico de libertos que legaram posses.

Talvez o quadro dicotômico se explique pela dificuldade de se encontrar fontes que retratem a vida de pessoas libertas e pobres e, que, no mais das vezes, não deixaram registros próprios. Optou-se, aqui, pela busca de informações de origens diferenciadas para examinar a trajetória desses sujeitos na cidade de Mariana na segunda metade dos setecentos, usando estratégias de pesquisas já consagradas, mas também adotando outras relativamente pouco exploradas pela historiografia.

Os documentos pesquisados foram registros de óbitos, testamentos, inventários postmortem e ações cíveis. O tratamento dado a essas fontes foi diferenciado. Lançamos mão de métodos da Demografia Histórica para quantificar os óbitos registrados entre os anos de 1751 a 1800, existentes em oito livros que se encontram no Arquivo Eclesiástico da Arquidiocese de Mariana, com o intuito de conhecer o contingente de libertos e os indícios de pobreza ou de posse por parte dos falecidos. Esses registros, pouco explorados com esse propósito, são elucidativos no que se refere à caracterização de uma população pobre que dificilmente aparece em outros repertórios documentais.

As outras fontes trabalhadas se encontram no Arquivo da Casa Setecentista de Mariana. Os testamentos e inventários tiveram algumas informações quantificadas, mas o objetivo mais geral do trabalho com esses dados foi apontar os aspectos econômicos que os libertos apresentavam no período próximo à morte, além de outras características importantes que marcaram suas vidas. Foram pesquisados 41 inventários e 69 testamentos. O número de testamentos foi ampliado para 91 a partir das cópias encontradas nos inventários analisados.

Em contrapartida, utilizamos as ações cíveis com o propósito de conhecer os principais conflitos cotidianos em que estiveram envolvidos no decorrer de suas vidas e quais as ações que marcaram suas trajetórias sociais. Essa documentação se divide basicamente em dois tipos, o primeiro relacionado às questões que envolviam o acesso à liberdade e o outro à cobrança por inadimplência ou descumprimento de alguma condição firmada em contrados verbais ou mesmo escrituras privadas. Para o primeiro tipo foram encontrados 41 processos e para o segundo 642, mas, destes, privilegiamos 50 a partir da variação tipológica disponível. Essas ações foram analisadas qualitativamente, priorizando o estudo de casos por meio da reconstituição de experiências individuais dispostas nas informações a que tivemos acesso. 
A presente dissertação pretende contribuir para o campo dos estudos sobre alforrias ao delimitar os diferentes aspectos que marcaram a vida dos libertos no que tange às conquistas inerentes à emancipação como o direito à propriedade, à mobilidade e à inserção na sociedade colonial marianense. A dissertação pretende também mostrar que, mesmo quando engrossaram o universo da pobreza, os libertos não estiveram fadados à desclassificação social. Ainda que a condição de pobreza predominasse, isso não impediu que grande parte deles optasse pelo acesso à liberdade e posteriormente se envolvesse em diferentes atividades comerciais. O status adquirido com a alforria foi, sem dúvida alguma, a característica mais importante e aquela que unificou trajetórias de vida tão diversificadas.

O primeiro capítulo visa apontar os aspectos administrativos, econômicos e sociais da região de Mariana no século XVIII, com o objetivo de elucidar os processos de alforria e o surgimento da população forra incorporada na dinâmica do sistema escravista ao longo desse mesmo século.

O segundo capítulo inicia a abordagem das mudanças ocorridas com a passagem da escravidão para a liberdade, discorrendo principalmente sobre o direito de acesso à propriedade. Buscou-se mostrar a inserção de alguns no conjunto de proprietários de escravos, bem como a inserção de outros na pobreza.

Ao considerar que o endividamento era generalizado na sociedade colonial mineira, procuramos, no terceiro capítulo, entender quais eram os negócios em que os libertos se envolveram na cidade de Mariana, e em que medida contraíam dívidas que poderiam levá-los a resolver suas contendas nas instâncias justiciais. A partir do endividamento, buscamos conhecer alguns dos motivos que poderiam ter gerado ou exacerbado a condição de pobreza entre pessoas desse segmento social.

O quarto capítulo visa mostrar outra experiência que permeou a vida dos libertos: a dúvida quanto à emancipação e o risco de retornarem à condição de cativos. Nesse momento buscou-se perceber quais circunstâncias levavam os senhores a anularem um contrato de libertação, ou mesmo reaver a posse de um emancipado. 


\section{CAPÍTULO 1}

\section{Escravidão, alforria e libertos em Mariana}

\subsection{A geografia política de Mariana}

A ocupação e o povoamento de Minas Gerais se deram em fins do século XVII e início do XVIII, com a descoberta de grandes jazidas auríferas na região. O acentuado fluxo de pessoas que se dirigiu para essas terras promoveu a expansão do território e a rápida exploração de suas riquezas. Os povoados foram se formando e transformando em centros da vida civil, religiosa, social e econômica. ${ }^{1}$ Nesses locais se encontravam pessoas das mais diferenciadas origens, como portugueses, africanos, ameríndios, dentre outros, que desempenharam diversificados papéis na formação da sociedade mineira.

Em 1709, “já se tornara necessária a criação de uma capitania independente, desmembrada do Governo do Rio de Janeiro”. Por meio de uma Carta Régia, datada de 9 de novembro daquele, estabeleceu-se a Capitania de São Paulo e Minas do Ouro, sob o governo de Antônio de Albuquerque Coelho de Carvalho. Em 1711, foram criadas as primeiras vilas nos locais onde a exploração do ouro mais se desenvolveu. Uma Provisão de 6 de abril de 1714 ainda dividiu a Capitania em três comarcas: "a de Vila Rica, a do Rio das Velhas, com sede em Sabará, e a do Rio das Mortes, em São João Del Rei.” Alguns anos mais tarde, em 2 de dezembro de 1720, a Capitania de Minas foi desmembrada da Capitania de São Paulo, "sob o governo de D. Lourenço de Almeida, e com o nome que lhe ficou de Minas Gerais”. ${ }^{2}$

A exploração aurífera representou a principal atividade econômica devido ao seu potencial produtivo e acesso fácil à riqueza. Entre os anos de 1700 a 1820, foram arrecadadas 7.129 arrobas e 162 marcos de ouro. ${ }^{3}$ Não obstante, essa produção não se manteve de maneira contínua no decorrer do século XVIII; a primeira metade caracterizou-se pelo auge de sua produção, e, a segunda metade, pelo período de declínio.

Nessa corrida desenfreada em busca de riquezas se deu a ocupação do Ribeirão de Nossa Senhora Carmo, a partir de 1696, por Miguel Garcia e Salvador Fernandes Furtado, em

\footnotetext{
${ }^{1}$ LIMA JÚNIOR, Augusto de. A Capitania das Minas Gerais: origens e formação. $3^{\text {a }}$ Edição. Belo Horizonte: Edição do Instituto de História, Letras e Arte, 1965, p. 59.

2 LIMA JÚNIOR, A Capitania das Minas Gerais, p.61-62.

${ }^{3}$ Dados estipulados por Von Eschwege e apresentados por Augusto de Lima Júnior. Ibdem, p.75. Virgílio Noya Pinto considera esse cálculo inferior ao correspondente a Minas Gerais e calcula que, entre os anos de 1700 e 1799, foram arrecadados cerca de 8.764 arrobas de ouro na região. PINTO, Virgílio Noya. O ouro brasileiro e o comércio anglo-português: uma contribuição aos estudos da economia atlântica no século XVIII. São Paulo: Ed. Nacional, 1979, Tabela 3, p. 114.
} 
um território que viria a se tornar uma das principais regiões da Capitania de Minas em função da profusão de suas riquezas minerais. Sua expansão também se tornou significativa desde o início da ocupação, conformando, já em 1701, uma zona composta por “vários pequenos arraiais que se formavam no serviço de minerar”. 4

A importância desse território se tornou tão evidente que logo houve a implantação do aparato administrativo por parte da Coroa Portuguesa, e, mais tarde, da administração eclesiástica, com o propósito de obter um controle maior sobre a população existente.

Em 1711, quando foram criadas as primeiras vilas, o arraial foi o primeiro a receber a instalação da Câmara Municipal e a se denominar como Vila de Nossa Senhora do Carmo, compreendendo a seguinte delimitação:

(...) sua primitiva jurisdição limitada pela sua posição geográfica, próxima a Vila Rica, cabendo-lhe as vertentes do Rio Doce, desde as nascentes, formadas entre outros pelos rios Piracicaba, Carmo, Piranga e Casca, até Cuieté; e ao Sul, os rios Pomba e Muriaé, até os limites com a antiga província do Rio de Janeiro. ${ }^{5}$

A região era composta por várias localidades caracterizadas tanto por áreas rurais como urbanas. Dos 46 distritos que pertenciam à sua jurisdição, eram os mais importantes: Passagem, Morro, Antônio Pereira, Camargos, Inficionado, São Sebastião, Catas Altas, São Caetano, Furquim, Barra, Sumidouro, Brumado, Pinheiro, Bacalhau, Guarapiranga e Itacolomi. ${ }^{6}$ Sua conformação permaneceu extensa até o final do século XVIII, quando ocorreu o desmembramento de alguns distritos devido à desagregação da organização política colonial. $^{7}$

A administração local era representada pelo Senado da Câmara, que cuidava das principais questões políticas, administrativas e econômicas. O Senado estava subordinado ao Governo da Capitania, mas possuía total autonomia para se comunicar com a Metrópole.

\footnotetext{
${ }^{4}$ LIMA JÚNIOR, A Capitania das Minas Gerais, p.35.

${ }^{5}$ COSTA, Joaquim Ribeiro. Toponímia de Minas Gerais. Belo Horizonte: Imprensa Oficial do Estado, 1970, p.78.

${ }^{6}$ COSTA, Toponímia de Minas Gerais, p.62.

${ }^{7}$ A criação das vilas na Capitania de Minas Gerais, entre os anos de 1711 e 1730, passou a ser vista em anos recentes pela historiografia como um aparato controlador e centralizador da política administrativa da Coroa Portuguesa na colônia, em especial nos distritos mineradores. Apesar do surgimento de diversos arraiais ao longo do século XVIII, e das constantes tentativas de emancipação, a maior parte não adquiriu autonomia política, permanecendo sob o controle do pólo minerador ao qual pertencia. Apenas em 1789, iniciam-se novas instalações. FONSECA, Cláudia Damasceno. Mariana, gênese e transformação de uma paisagem cultural. Dissertação de Mestrado em Geografia e Organização Humana do Espaço, Universidade Federal de Minas Gerais, Instituto de Geociências, 1995, p.88; e Des Terres Aux Villes de L'Or: Pouvoirs et territoires urbains au Minas Gerais (Brésil, XVIII ${ }^{e}$ siècle). Paris: Fundação Calouste Gulbenkian, 2003, p. 25-27.
} 
Seguindo as determinações da Coroa Portuguesa quanto à aplicação de suas leis, decretos e bandos, a Câmara Municipal era o órgão responsável por gerenciar todas as questões relacionadas à vida cotidiana, voltadas principalmente para a disciplina no âmbito urbano. Os principais membros que a compunham se dividiam entre os cargos de juízes, vereadores e procurador. Além desses, havia ainda os empregados que se encarregavam do cumprimento das leis e posturas, abastecimento da população, fiscalização, etc. ${ }^{8}$

A ocupação dos cargos administrativos mais importantes, a princípio, se restringiria a um determinado grupo de pessoas, geralmente formado pelas elites locais, denominados como "homens bons". Entre os indivíduos que gozavam de maiores privilégios, os portugueses e seus descendentes predominavam, geralmente por apresentarem maior poder econômico. Mas, na Capitania de Minas no século XVIII, também houve a presença de descendentes de africanos ocupando alguns cargos públicos no início desse mesmo século. Segundo Boxer, “pela lei, sangue negro era obstáculo para ocupar qualquer cargo cívico ou oficial, tal como uma cadeira na Câmara Municipal, mas essa barreira de cor era frequentemente transposta”. Isso se deu em função do aumento dos mulatos naquela região, que, por vezes, tornavam-se pessoas de posses. ${ }^{9}$ Era a prevalência do critério da riqueza sobre o da cor.

A região também se destacou por sua importância religiosa. Em 6 de dezembro de 1745 a vila foi elevada à categoria de cidade para acolher a sede do primeiro arcerbispado de Minas Gerais, recebendo então o nome de Leal Cidade de Mariana. ${ }^{10}$ Antes desse período, “a atuação da Igreja (...) era feita através das visitas diocesanas dos bispos do Rio de Janeiro”,11 mantidas pela população laica já estabelecida naquela localidade.

Instalada a paróquia, passaram a pertencer à sua jurisdição 56 freguesias localizadas nas Comarcas de Vila Rica, Sabará, Serro e São João Del Rei. ${ }^{12}$ Além de cuidar das questões espirituais e de promover a fé católica, a igreja detinha ainda importantes obrigações civis,

\footnotetext{
${ }^{8}$ ANDRADE, Francisco Eduardo de. Poder local e herança colonial em Mariana: faces da revolta dos “Ano da Fumaça” (1833). Termo de Mariana. Mariana: Imprensa Universitária da UFOP, 1998, p.127.

${ }^{9}$ BOXER, Charles R.. A Idade do Ouro no Brasil: dores de crescimento de uma sociedade colonial. Tradução de Nair Lacerda. $3^{a}$ Edição. Rio de Janeiro: Nova Fronteira, 2000, p.192. Cf. RUSSELL-WOOD, A.J.R. “O Governo Local na América Portuguesa: um estudo de divergência cultural”. Revista de História, São Paulo, nº109, v.50, 1997, p. 38.

${ }^{10}$ MATOS, Raimundo José da Cunha. Corografia histórica da província de Minas Gerais. Belo Horizonte: Itatiaia, 1981, p.101.

${ }^{11}$ SILVA, Marilda Santana da. Dignidade e Transgressão: mulheres no Tribunal Eclesiástico em Minas Gerais (1748-1830). Campinas: Editora da Unicamp, 2001, p.53.

${ }^{12}$ LEWKOWICZ, Ida. Vida em família: caminhos da igualdade em Minas Gerais (séculos XVIII e XIX). São Paulo, Tese de Doutorado, FFLCH/USP, 1992, p. 51.
} 
trabalhos esses que simbolizavam a união das sociedades civil e católica, e consolidavam ainda mais a dominação metropolitana. ${ }^{13}$

A base de funcionamento do Bispado de Mariana se encontrava nas Constituições Primeiras do Acerbispado da Bahia, assim como para todos os bispados do Brasil colonial, e era exercido pelo Juízo Eclesiástico. Esse órgão, também regularizado pela justiça clerical da colônia, cuidava das questões referentes aos julgamentos. Era formado por três esferas que correspondiam a um corpo local, composto pelo bispo e sua câmara episcopal; ao tribunal do arcerbispado da Bahia, denominado Relação Metropolitana; e por último, ao Tribunal Metropolitano de Portugal. A câmara episcopal era composta por vigário-geral, promotor, advogado, escrivão, meirinho e vigário da vara, e se dividia entre membros predominantemente com formação canônica, mas também indivíduos da sociedade civil. ${ }^{14}$

Além das reconhecidas funções de dominação espiritual e civil exercidas pela Igreja em Mariana no século XVIII, a função educacional também teve seu destaque a partir da instalação do Seminário de Nossa Senhora da Boa Morte, em 1750, que acabou atraindo pessoas de diferentes regiões interessadas em lecionar ou estudar. A educação na Leal Cidade, antes desse período, restringia-se apenas ao ambiente domiciliar devido à ausência de escolas régias, que somente surgiram a partir de 1774.

A consolidação do aparato religioso e administrativo, na primeira metade do século XVIII, foi concomitante ao processo de urbanização, que atribuiu à região central de Mariana funções muito importantes associadas à vida cotidiana, transformando-a no

(...) local onde todos os habitantes do município tinham que resolver seus problemas com a administração. Lá estavam os tabeliães e os advogados que registravam e resolviam os conflitos e também tornavam legítimos testamentos e inventários, terras, ajustes, processos crimes. ${ }^{15}$

Várias atividades se desenvolveram no espaço urbano, ocasionando crescente demanda por mão-de-obra. As funções relacionadas aos serviços burocráticos exigiam, em grande medida, profissionais qualificados; as que se ligavam ao setor econômico, mais voltado às áreas que deveriam atender às necessidades da crescente população local, atrelavam-se a um número maior de trabalhadores, nem sempre dotados de atributos

\footnotetext{
${ }^{13}$ Faziam parte das principais funções desenvolvidas por vigários e demais funcionários que compunham o corpo da administração eclesiástica, a confecção de "listas dos jurisdicionados e fregueses" e os "lançamentos relativos a nascimentos, casamentos e óbitos”. LIMA JÚNIOR, A Capitania das Minas Gerais, p. 151.

${ }^{14}$ Marilda Santana esclarece que o oficial que não tivesse como requisito a formação canônica, deveria, ao menos, ser cristão velho. SILVA, Dignidade e Transgressão, p. 64.

${ }^{15}$ LEWKOWICZ, Vida em família, p. 49.
} 
específicos. Mas nenhuma atividade econômica desenvolvida nas proximidades do ambiente urbano despendeu tanta mão-de-obra como a mineração.

\subsection{Economia e escravidão}

A enorme atenção conferida pelos estudiosos da economia colonial à região de Minas Gerais se justifica pela dinâmica da mineração. Diferenciadas atividades econômicas foram desenvolvidas a partir da ocupação das regiões auríferas com o objetivo de atender às necessidades condizentes com o cotidiano das pessoas que viviam nas proximidades das lavras minerais. Caracterizadas pela agricultura, comércio, prestação de serviços, dentre outros, essas atividades geralmente eram executadas por escravos ou pessoas livres e auxiliavam a manutenção da principal atividade econômica. Dessas, a que mais gerou polêmica entre os estudiosos foi aquela relacionada à agricultura de subsistência. ${ }^{16}$

As abordagens da historiografia tradicional sempre conferiram à agricultura voltada ao abastecimento um papel secundário na economia colonial. Os trabalhos publicados entre os anos 1940 e 1960 revelaram que a extensa atividade aurífera foi acompanhada por essa atividade, em menor escala, e pela intensa importação de bens de consumo. ${ }^{17}$

Em 1942, Caio Prado Júnior elucidou a diferença entre "grande lavoura” e “agricultura de subsistência”, destacando que a primeira se caracterizava pela produção do “açúcar, algodão e outros gêneros de menor importância”, destinados ao mercado externo, enquanto que a agricultura de subsistência se limitava à produção de bens para o consumo interno. ${ }^{18}$ Ainda assim, Celso Furtado, em 1959, e Sérgio Buarque de Holanda, em 1960,

\footnotetext{
${ }^{16}$ Segundo Carla Almeida, há "desde autores que apontam a existência e mesmo formulam questões a respeito da importância dessas atividades, até aqueles que negam ou subestimam a presença da agricultura”. ALMEIDA, Carla Maria Carvalho de. Alterações nas atividades produtivas mineiras, Mariana, 1750 a 1800. Dissertação de Mestrado, Universidade Federal Fluminense, Niterói,1994, p.63.

${ }^{17}$ PRADO JÚNIOR, Caio. Formação do Brasil Contemporâneo. São Paulo: Brasiliense, 1942; FURTADO, Celso. Formação econômica do Brasil. 15a ed. São Paulo: Ed. Nacional, 1977; HOLANDA, Sérgio Buarque de. "Metais e pedras preciosas". In: História Geral da Civilização Brasileira, A Época Colonial, Administração, Economia, Sociedade. Tomo 1, V.2, $1^{\text {a }}$ Edição. São Paulo: Difel, 1973. BOXER, Charles R. A idade do Ouro no Brasil: dores de crescimento de uma sociedade colonial. Tradução de Nair Lacerda, $3^{\mathrm{a}}$ Edição, Rio de Janeiro: Nova Fronteira, 2000 e LUNA, Francisco Vidal. Minas Gerais: escravos e senhores - análise da estrutura populacional e econômica de alguns centros mineratórios (1718-1804). São Paulo: Publicado para o Instituto de Pesquisas Econômicas, 1981.

${ }^{18}$ PRADO JR., Formação do Brasil Contemporâneo, p. 142.
} 
apontaram para a formação de um dinâmico mercado interno, em Minas, que articulou diferentes regiões do centro-sul do país. ${ }^{19}$

Para Charles Boxer, o desenvolvimento da agricultura vigorou a partir do crescimento da população que se instalou nas regiões mineradoras, demandando volumes cada vez maiores de bens de consumo. Logo, a importância dessa atividade foi percebida por diversos colonos que passaram a se ocupar da função. Conforme constatou esse autor,

Pequenas granjas e fazendas depressa se foram instalando ao longo das estradas, e mais atenção mereceu o plantio de hortaliças, milho e a criação de rebanhos nas vizinhanças dos principais campos auríferos, que se iam, lentamente, transformando em vilas. ${ }^{20}$

Anos mais tarde, novas revisões acerca da economia mineira foram levantadas, apresentando diferenciadas opiniões dos pesquisadores no que tange à importância da agricultura e outras atividades auxiliares à mineração. ${ }^{21}$ Com relação à região de Mariana sabemos que a população movida pela busca incessante de riqueza pareceu descuidar-se das atividades de subsistência nos primeiros tempos da exploração, dedicando-se de maneira mais acentuada ao trabalho aurífero. Vários são os relatos que abordam a freqüência das crises de fome enfrentadas pelos primeiros desbravadores. Esses relatos também nos informam sobre o conseqüente abandono de algumas das áreas inicialmente ocupadas. ${ }^{22}$ Não obstante, as pesquisas desenvolvidas a partir da década de 1980, que incluem a região de Mariana, mostram que a exploração aurífera conviveu com a agricultura de subsistência desde o início de sua ocupação. Algumas zonas de Minas chegaram até mesmo a apresentar um importante caráter mercantil, em determinados momentos.

Analisando 1.247 cartas de sesmarias de Minas Gerais, Carlos Magno Guimarães e Liana Maria Reis verificaram que as informações contidas nestes papéis traziam demasiadas referências com relação à simultaneidade das atividades exercidas, tanto de "roças como de minerar”, ou seja, a agricultura e a mineração. Quando havia a indicação de atividades agrícolas, perceberam ainda que essa agricultura foi exercida pela mão-de-obra cativa com o objetivo de prover o sustento das famílias existentes, além da própria escravaria. Também há referências ao transporte de mantimentos para as vilas, apontando para a dinâmica de um

\footnotetext{
${ }^{19}$ FURTADO, Formação econômica do Brasil, p.77; HOLANDA, “Metais e pedras preciosas”, p.309.

${ }^{20}$ BOXER, A idade do Ouro no Brasil, p.71.

${ }^{21}$ Para maiores informações sobre essas discussões ver: GUIMARÃES, Carlos Magno; REIS, Liana Maria. “Agricultura e escravidão em Minas Gerais (1700/1750)”. Revista do Departamento de História. BH, FAFICH/UFMG, n², jun. 1986, p.9-14; ALMEIDA, Alterações nas atividades produtivas mineiras, p.56-72.

${ }^{22}$ ALMEIDA, Alterações nas atividades produtivas mineiras, p. 43.
} 
mercado interno. ${ }^{23}$ Esses autores então concluem que "o objetivo da produção agrícola era o sustento de senhores e escravos, para que estes pudessem ser utilizados na atividade nuclear: a mineração”. Portanto, reconhecem que “a produção interna em momento algum, na primeira metade do século, possa ter satisfeito integralmente as necessidades de reprodução da sociedade mineira”. ${ }^{24}$ Os centros urbanos foram abastecidos de gêneros produzidos nas roças e sítios locais e também por produtos transportados a longas distâncias. ${ }^{25}$

Para a segunda metade do século XVIII, contamos com informações mais específicas sobre a região de Mariana. Analisando as unidades produtivas, entre os anos de 1750-1850, por meio de inventários post-mortem, Carla Almeida estabelece uma periodização para o desenvolvimento da economia mineradora marianense. Considera três subperíodos, a saber: auge da mineração entre os anos de 1750 a 1770, acomodação evolutiva entre 1780 e 1810, e por fim, economia mercantil de subsistência entre 1820 e $1850 .{ }^{26}$ Ao tratar da relação entre mineração e agricultura, a autora percebe um aumento dos instrumentos de trabalho no período de crise da mineração, fator que indica a manutenção da produção de subsistência e seu gradativo estabelecimento até as décadas consideradas como de acomodação evolutiva.

Os trabalhos supracitados contribuíram de maneira fundamental para a refutação das afirmações sobre a completa estagnação e involução econômica da agricultura em Minas no período de apogeu da mineração. Ao contrário dessa visão, percebemos que esta atividade foi significativa na economia mineira, durante a primeira metade do século XVIII, e, especificamente em Mariana, já se apresentava de maneira altamente diversificada, envolvendo ao mesmo tempo "atividades agrícolas, pecuaristas e manufatureiras, muitas vezes acompanhadas de alguma mineração", ${ }^{27}$ Todavia, não ocorreu uma substituição de uma atividade a outra; "o que houve foi um processo gradual de adaptação e acomodação que modificou estas mesmas estruturas". ${ }^{28}$

O período que se entende como de decadência da mineração pode ser explicado não pelo esgotamento do ouro, mas sim por uma fase em que o processo de extração se tornou

\footnotetext{
${ }^{23}$ GUIMARÃES; REIS, “Agricultura e escravidão em Minas Gerais”, p. 24.

${ }^{24}$ GUIMARÃES; REIS, “Agricultura e escravidão em Minas Gerais”, p. 33.

${ }^{25}$ CHAVES, Cláudia Maria das Graças. Perfeiros Negociantes: mercadores das minas setecentistas. São Paulo: Annablume, 1999, p.164.

${ }^{26}$ ALMEIDA, Alterações nas atividades produtivas mineiras, p. 85-101.

${ }^{27}$ ALMEIDA, Alterações nas atividades produtivas mineiras, p. 71.

${ }^{28}$ LIBBY, Douglas Cole. "Novas considerações sobre a protoindustrialização mineira dos séculos XVIII e XIX”. Revista do Departamento de História. BH, FAFICH/UFMG, nº9, 1989, p.155.
} 
mais dispendioso do que a economia poderia suportar. Não indica que a mineração deixou de ser praticada, tão só a maior valorização das atividades agropastoris. ${ }^{29}$

Estiveram envolvidos com o setor agrícola grandes mineradores por meio de seus escravos, mas também pequenos trabalhadores rurais com o auxílio de suas famílias. Os primeiros buscavam primordialmente a subsistência de seus cativos, em detrimento dos outros que viam nessa ocupação não somente um meio de sobreviver, mas de poder construir algum patrimônio diante da incessante demanda que a economia mineradora colocou.

O comércio local também foi uma atividade econômica desenvolvida em todo o período colonial que não sofreu diretamente as oscilações do mercado externo, como a mineração, contudo foi impulsionado pelas necessidades do cotidiano de um ambiente urbano. De um modo geral, esse comércio se apresentava de duas formas, fixo ou ambulante. Sobre Minas Gerais, sabemos que,

De início, estabeleceram-se lojas, vendas e tabernas, além de feiras e de uma rede comercial de abastecimento. Posteriormente, enquanto os rendimentos das empresas comerciais aumentavam, os mercadores fixaram-se nas áreas de mineração, como aconteceu com logistas e vendeiros. Esses grupos de comerciantes, negociando produtos básicos para a subsistência, passaram a controlar o mercado mineiro. ${ }^{30}$

Percebemos também que, na historiografia sobre esse assunto, há divergências quanto à classificação do comércio fixo em Minas Gerais. Encontramos três denominações, utilizadas pelos pesquisadores de forma diferenciada: vendas, lojas ou tabernas. ${ }^{31}$ Ainda que apresentem características distintas, de maneira geral, esses comércios eram pontos onde ocorriam as principais negociações referentes ao abastecimento da população. Dentre os produtos comercializados, encontravam-se gêneros alimentícios e objetos que fossem necessários para o cotidiano das pessoas, como tecidos e quinquilharias de maneira geral. ${ }^{32}$ Os gêneros eram classificados como da terra e do reino.

Respeitando a Postura da Câmara Municipal de Mariana de 1715, os proprietários desses comércios deveriam obter uma licença de funcionamento e ainda pagar um imposto bimestral denominado almotaçaria. Com esse procedimento, o estabelecimento passaria por

\footnotetext{
${ }^{29}$ ALMEIDA, Alterações nas atividades produtivas mineiras, p. 55. Cf. HOLANDA, "Metais e pedras preciosas", p. 306.

${ }^{30}$ MAGALHÃES, Sônia Maria de. A mesa de Mariana: produção e consumo de alimentos em Minas Gerais (1750-1850). São Paulo: Anablume/Fapesp, 2004, p.66.

${ }^{31}$ MAGALHÃES, A mesa de Mariana, p.66-70. Para uma discussão mais detalhada, ver também BORREGO, Maria Aparecida de Menezes. A Teia Mercantil: negócios e poderes em São Paulo colonial (1711-1765). Doutorado em História, FFLCH-USP, 2006, p.65-125.

${ }^{32}$ MAGALHÃES, A mesa de Mariana, p.66.
} 
uma inspeção com o objetivo de se ajustar balanças, pesos e medidas e, principalmente, os preços dos gêneros vendidos, para que não ocorressem abusos nos seus valores e os alimentos pudessem ser consumidos por toda a população. ${ }^{33}$ Portanto, o exercício do comércio no espaço urbano poderia se tornar uma prática muito promissora para quem quisesse obter propriedades. ${ }^{34}$ As atividades manuais também se apresentavam como uma boa opção em um ambiente onde o trabalho compulsório deveria atender às necessidades da sociedade formada pelo impulso das atividades da mineração.

Assim como o comerciante fixo, os comerciantes ambulantes, oficiais mecânicos, professores ou quaisquer profissionais que desejassem exercer sua profissão, deveriam anteriormente obter uma licença da Câmara Municipal. Essas eram as pessoas que de, alguma forma, estavam econômica ou profissionalmente envolvidas com o desenvolvimento da região.

A sociedade mineira do período colonial conheceu a importância do trabalho manual para o desenvolvimento da economia. Funções diversificadas exigiam também mão-de-obra variada. Mas nenhuma atividade careceu de maior volume de trabalhadores como aquela despendida com as funções da extração aurífera. O que incentivou a propriedade escrava na primeira metade do século XVIII foi a legislação que permitiu a ocupação e exploração das terras auríferas. Tais concessões deveriam ser proporcionais ao tamanho do plantel. ${ }^{35}$ Ainda que um faiscador obtivesse uma porção módica para explorar, o produto do seu trabalho certamente propiciaria lucro que o tornaria capaz de obter sua própria mão-de-obra cativa, gerando não somente o aumento de sua produção, mas acima de tudo a ampliação de suas

\footnotetext{
${ }^{33}$ A partir da constatação de numerosas correspondências oficiais das Câmaras municipais referentes à questão do abastecimento, Carla Anastasia e Flávio Marcus da Silva afirmaram acreditar que "desde o início do século XVIII, houve nas Minas uma política deliberada de estímulo à produção agropecuária nas proximidades dos centros urbanos, o que, aliado a uma intervenção constante no mercado interno, preveniu a ocorrência de crises de subsistência”. Essa prática objetivou ainda resguardar as regiões de maior concentração populacional, em especial as mineradoras, de possíveis tensões, ou até mesmo, sublevações populares, caso houvesse carência de alimentos. ANASTASIA, Carla Maria Junho e SILVA, Flávio Marcus da. "Levantamentos setecentistas mineiros”. In: FURTADO, Júnia Ferreira (org.). Diálogos Oceânicos: Minas Gerais e as novas abordagens para uma história do Império Ultramarino Português. Belo Horizonte: Editora UFMG, 2001, p. 318. Para Luciano Figueiredo, essa política, instaurada pelo exercício tributário, viabilizou ainda mais a possibilidade da Coroa avultar seus cofres públicos. FIGUEIREDO, Luciano Raposo. O avesso da memória: cotidiano e trabalho da mulher em Minas Gerais no século XVIII. Rio de Janeiro: José Olympio; Brasília, DF: Ednub, 1993, p.49.

${ }^{34}$ Os trabalhos são unânimes em afirmar a marcante presença dos libertos na atividade comercial, além de apresentar forte predominância de mulheres entre os proprietários de vendas e, principalmente, como vendedoras ambulantes, muito embora essa segunda categoria esteja associada à condição de pobreza desses indivíduos. Ver: FIGUEIREDO, O avesso da memória: cotidiano e trabalho da mulher em Minas Gerais no século XVIII. Rio de Janeiro: José Olympio; Brasília, DF: Ednub, 1993 e DIAS, Maria Odila Leite da Silva. Quotidiano e poder em São Paulo no século XIX. $2^{\mathrm{a}}$ ed., São Paulo: Brasiliense, 1995.

${ }_{35}$ RIBEIRO, Núbia Braga Ribeiro. Cotidiano e liberdade: um estudo sobre os alforriados em Minas no século XVIII. Dissertação de Mestrado, FFLCH/USP, São Paulo, 1996, p.28.
} 
posses territoriais. ${ }^{36}$ As primeiras técnicas baseavam-se apenas no manuseio de instrumentos rudimentares, como as bateias. O uso intensivo da força de trabalho na mineração passou a vigorar a partir do esgotamento do ouro aluvional, quando surgiu a necessidade da utilização de técnicas de exploração mais elaboradas, como as construções de barragens, perfurações de galerias e das encostas dos morros ou redirecionamento dos leitos dos rios. ${ }^{37}$

A mão-de-obra escrava tornou-se fundamental para o desenvolvimento das atividades econômicas na colônia, além de alimentar o vigoroso e lucrativo comércio transatlântico de africanos para a América Portuguesa. Grande parte dos africanos conduzidos a Minas Gerais era destinada à exploração mineral. ${ }^{38}$ Não obstante, essa importante força de trabalho não se restringiu apenas às atividades mineradoras e agrícolas, uma vez que o espaço urbano também direcionou algumas funções mais específicas à população cativa.

De maneira geral, os escravos e libertos, nas cidades, puderam suprir as demandas de mão-de-obra naqueles serviços que não eram bem vistos pela sociedade colonial. $\mathrm{Na}$ colônia, as atividades desenvolvidas por escravos eram aquelas que homens que alcançavam status jamais poderiam exercer; em outros termos, o trabalho era associado ao indivíduo escravo, pois “o não-trabalho era meio de nobilitação”. ${ }^{39}$ Mesmo se tratando de imigrantes que, por vezes, dirigiram-se para colônia por motivo de empobrecimento, ${ }^{40}$ os princípios da

\footnotetext{
${ }^{36}$ LUNA, Minas Gerais: escravos e senhores, p. 11.

${ }^{37}$ LUNA, Minas Gerais: escravos e senhores, p. 41-49. A aplicação dessas técnicas se deu a partir da chegada de práticos que se dirigiram para as Minas com forasteiros, ou que foram enviados por ordem das autoridades portuguesas, com o intuito de aperfeiçoar e otimizar a extração mineral no período de seu esplendor. HOLANDA, "Metais e pedras preciosas", p.273-275. Entretanto, a partir do momento em que ocorreu o esgotamento das jazidas, aumentou o número de faiscadores. Cf. PRADO JR., Formação do Brasil Contemporâneo, p.178-199 e FURTADO, Formação Econômica do Brasil, p. 84.

${ }^{38}$ Para Blackburn, a mineração, na América Portuguesa, impulsionou as importações anuais de africanos, chegando a duplicá-las em determinados momentos. BLACKBURN, Robin. A queda do escravismo colonial: 1776-1848. Tradução: Maria Beatriz Medina. Rio de Janeiro: Record, 2002, p.24. O comércio carioca de africanos contribuiu para a reprodução do escravismo no sudeste, sobretudo para a região das Minas Gerais a partir descoberta dos veios auríferos. No primeiro momento, calcula-se que houve o deslocamento de cerca de 2.300 escravos do Rio de Janeiro para essa região entre os anos de 1715 a 1727. A capitania continuou a absorver grande parte desses africanos - aproximandamente de 40 a $60 \%$ - durante todo o século XVIII, quando suas atividades se voltaram para a economia de abastecimento em localidades mais ao sul. FLORENTINO, Manolo Garcia Em costas negras: uma história do tráfico atlântico de escravos entre a África e o Rio de Janeiro: séculos XVIII e XIX São Paulo: Companhia das Letras, 1997, p. 37-39.

${ }^{39}$ SOARES, Lucas Jannoni. Presença dos homens livres pobres na sociedade colonial na América Portuguesa, São Paulo (1765-1775). Dissertação de Mestrado, São Paulo, FFLCH/USP, 2005, p.13.

${ }^{40}$ MESGRAVIS, Laima. "Os aspectos estamentais da estrutura social do Brasil colônia”. Estudos Econômicos, n ${ }^{\circ} 13,1983$, p.803. Jorge Pedreira também faz algumas ressalvas no que diz respeito à imagem de pobreza e condição social degradada dos imigrantes portugueses que se envolveram com o comércio na colônia, uma vez que não estiveram apenas associadas à carência de recursos, mas também ao fato de muitos partirem de suas terras com pouca idade, entre os quinze e vinte anos, chegando, portanto, com conhecimentos limitados. Em suas palavras, "não contavam certamente, porém, com os cabedais necessários para se se lançarem imediatamente no negócio por grosso, e na maioria dos casos começavam por baixo, pelos escalões inferiores da atividade mercantil". PEDREIRA, Jorge M. "Brasil, fronteira de Portugal. Negócio, emigração e mobilidade social (séculos XVII e XVIII)". Anais da Universidade de Évora, no 8 e 9, dezembro 1998/1999, p. 64. Eram esses comerciantes locais que ascendiam social e economicamente, que ocupavam os cargos oficiais oferecidos pelo
} 
hierarquização social permaneciam os mesmos, ou seja, "a afirmação dos valores aristocráticos do ócio e da ostentação e a condenação dos burgueses como o trabalho e o comércio, na prática revelava o predomínio da nobreza como estamento (...)”. ${ }^{4}$

Atividades como os serviços domésticos, ofícios mecânicos, trabalhos braçais, assim como atividades artísticas e produção de bens de consumo foram desenvolvidas tanto pelos escravos, como pelos coartados e libertos. No caso das mulheres, eram muito comuns os serviços domésticos, como o de lavadeiras e cozinheiras, além das funções como parteiras. Na escravidão urbana, a ocupação da mão-de-obra escrava e forra nessas atividades se deu em grande medida devido à maior flexibilidade e liberdade de movimentação em relação àqueles que trabalhavam no campo. O espaço urbano proporcionou a esses sujeitos maior abertura ao desenvolvimento de atividades que demandavam menor esforço físico e, principalmente, o lugar onde as mulheres puderam exercer ofícios que se distanciavam dos serviços domésticos, como o comércio.

\subsection{Os escravos de Mariana}

A economia mineradora contribuiu para a conformação da maior população escrava da América Portuguesa. Esse contingente se manteve predominante por todo o período colonial. Calcula-se, para a primeira metade do século, um contingente de 27.909 escravos em 1717, 31.500 em 1719 e 52.348 em $1728 .^{42}$ Os maiores índices seriam alcançados nas décadas seguintes, intensificados pelo crescente tráfico de africanos e, em menor grau, pela autoreprodução.

Não contamos com dados populacionais muito consistentes para o período colonial, e, sobre a população escrava, dispomos apenas de dois tipos de fontes documentais, como as listas de capitação, para a primeira metade do século XVIII, e os censos, para a segunda.

As listas de capitação resultam no levantamento da população escrava referentes aos anos de 1735 a 1750, com o objetivo de cobrar os impostos relativos à exploração aurífera. Essas listas eram produzidas pelas Intendências, órgãos localizados nos principais distritos

poder local. Tratava-se de mineradores, mercadores, comerciantes e produtores agrícolas. RUSSELL-WOOD, “O governo local na América Portuguesa”, p. 27.

${ }^{41}$ MESGRAVIS, “Os aspectos estamentais”, p.801-802.

42 BERGAD, Laird W. Escravidão e História Econômica: demografia de Minas Gerais, 1720-1888. Tradução de Beatriz Sidou. Bauru, SP: EDUSC, 2004, p.147. O autor afirma que quaisquer dados sobre a população escrava em Minas Gerais anteriores a 1730 são apenas estimativas. Somente a partir de 1730, com o imposto de capitação, é possível obter dados mais precisos. 
das Minas, entre os meses de janeiro e junho, e depois encaminhadas ao Governo da Capitania, que então as enviaria ao Conselho Ultramarino. ${ }^{43}$ Estava sujeita ao pagamento desse tributo grande parcela da população economicamente ativa da sociedade, como todas as pessoas relacionadas com a atividade de extração do ouro, prestações de serviços em geral, comerciantes, afora os proprietários de escravos e, por fim, os libertos, que deveriam pagar a taxa referente a si mesmos.

Não obstante as críticas quanto à natureza da fonte, essas listas são bastante difundidas entre as pesquisas sobre o quadro econômico e social do período colonial mineiro. Por meio delas, pode-se perceber o desempenho da produção aurífera, como também conhecer aspectos que envolvem a escravidão na primeira metade do século XVIII. Aqui nos interessa propriamente tentar estabelecer, a partir de dados trabalhados por outros pesquisadores, uma aproximação do que seria o contingente de escravos na primeira metade do século XVIII, como mostra o gráfico a seguir:

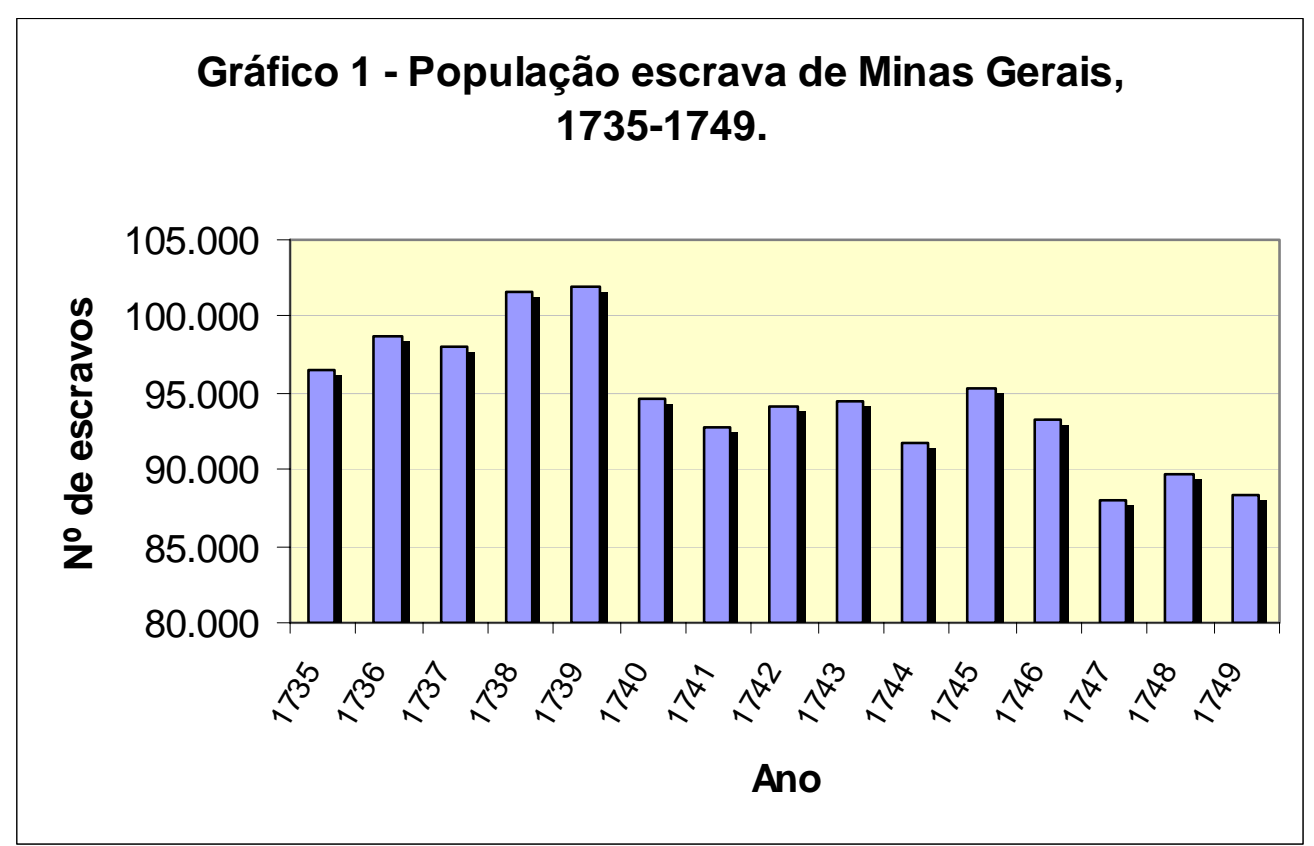

Fonte: BERGAD, Laird W. Escravidão e História econômica: demografia de Minas Gerias, 17201888, p. 149.

Nota: O gráfico contém informações das seguintes localizações: Vila Rica, Mariana, Sabará, Rio das Mortes, Serro do Frio, Sertões e Paracatu.

Percebemos que a maior concentração desses escravos se deu entre os anos de 1738 e 1739; a partir desse período há oscilações que indicam um decréscimo relativamente

${ }^{43}$ GONÇALVES, Andréa Lisly. "O Mapa dos negros que se capitaram e a população forra em Minas Gerais (1735-1750)”. Varia História, n²1, julho de 1999, p.145. 
moderado. O ano de 1739 apresenta o índice mais alto da população cativa com aproximadamente 102.010 escravos, enquanto o ano de 1749 mostra o menor valor, indicando 88.286. A média dos escravos para todo o período é de 95.618. Para tanto, é importante salientar que esses números apresentam apenas uma aproximação do que seria o contingente de escravos em Minas Gerais, na primeira metade do século XVIII, uma vez que é de fundamental importância consideramos as restrições inerentes às listas de capitação dada a evasão fiscal.

Para a segunda metade do século XVIII, contamos apenas com os censos referentes aos anos de 1776 e 1786. Em 1776 existiam cerca de 319.769 habitantes, sendo 163.240 escravos e 156.529 livres. Já em 1786 sabemos que se contou 326.847 habitantes, 174.135 escravos e 188.712 livres. $^{44}$

Os maiores índices de população cativa da Capitania de Minas Gerais se faziam presentes nas principais regiões auríferas e urbanas, como Vila Rica, Mariana e Sabará. Reafirmando essa constatação, Laird Bergad diz que

(...) as listas de capitação de escravos revelam que antes de 1750 quase metade de todos os escravos adultos, e por inferência, cerca de metade da população total viviam muito próximas dos locais onde ocorreram as primeiras descobertas de ouro no final do século 17, nos arredores de Vila Rica e Mariana. ${ }^{45}$

Mariana apresentou as taxas mais altas, totalizando 26.1\% dos escravos, seguida por Sabará com 22.6\% e Vila Rica com 21.6\%. Para compreendermos melhor a escravidão em Mariana, torna-se necessário verificarmos os dados da tabela abaixo, organizada por Laird Bergad, e que compreende as informações anteriormente apresentadas e ainda uma data não inserida no gráfico anterior.

\footnotetext{
${ }^{44}$ GORENDER, Jacob. O escravismo colonial. São Paulo: Editora Ática, 1985, p.454.

${ }^{45}$ BERGAD, Escravidão e História Econômica, p. 150-151.
} 


\begin{tabular}{|c|c|c|c|c|c|}
\hline \multicolumn{5}{|c|}{ Tabela 1 - População Escrava em Mariana, 1717-1808. } \\
\hline Ano & $\begin{array}{c}\text { População } \\
\text { Escrava }\end{array}$ & $\begin{array}{c}\text { \% dos escravos } \\
\text { de Minas Gerais }\end{array}$ & Ano & $\begin{array}{c}\text { População } \\
\text { Escrava }\end{array}$ & $\begin{array}{c}\text { \% dos escravos } \\
\text { de Minas Gerais }\end{array}$ \\
\hline 1717 & 6.834 & 24.5 & 1741 & 26.149 & 28.1 \\
\hline 1718 & 10.974 & 31.3 & 1742 & 25.491 & 27.1 \\
\hline 1719 & 10.937 & 31.3 & 1743 & 25.495 & 27.0 \\
\hline 1720 & 9.812 & 31.1 & 1744 & 24.448 & 26.7 \\
\hline 1728 & 17.376 & 33.2 & 1745 & 23.438 & 24.6 \\
\hline 1735 & 26.892 & 27.8 & 1746 & 22.891 & 24.5 \\
\hline 1736 & 26.752 & 27.1 & 1747 & 21.866 & 24.8 \\
\hline 1737 & 26.584 & 27.1 & 1748 & 21.331 & 23.8 \\
\hline 1738 & 26.532 & 26.1 & 1749 & 20.539 & 23.2 \\
\hline 1739 & 26.545 & 26.0 & $\mathbf{1 8 0 8}$ & 19.020 & 13.9 \\
\hline 1740 & 26.082 & 27.5 & & & \\
\hline
\end{tabular}

Fonte: BERGAD, Laird W. "Depois do boom: aspectos demográficos e econômicos da escravidão em Mariana, 1750-1808”. São Paulo: Estudos Econômicos, 24(3), Dez.1994, p. 499.

Em primeiro lugar, é importante considerarmos o percentual de escravos da região de Mariana com relação aos existentes na Capitania de Minas Gerais. Apesar das oscilações na primeira metade do século, concluímos que a queda mais brusca só acontece quando comparamos as primeiras décadas do século XVIII, em especial o ano de 1728, com uma taxa de $33.2 \%$, com o ano de 1808, que apresenta 13.9\% do total de cativos. A passagem do século XVIII para o XIX apresentou uma redução da escravaria em Mariana com relação ao restante da Capitania de Minas. A média de escravos na vila é de 27,1\% entre os anos de 1717 até 1749. O ano de 1808 apresenta uma porcentagem de apenas $13.9 \%$ com relação ao total dos escravos da Capitania.

A análise mais significativa é percebida quando se considera apenas os dados referentes à dinâmica interna dessa população, conforme verificamos no gráfico abaixo: 


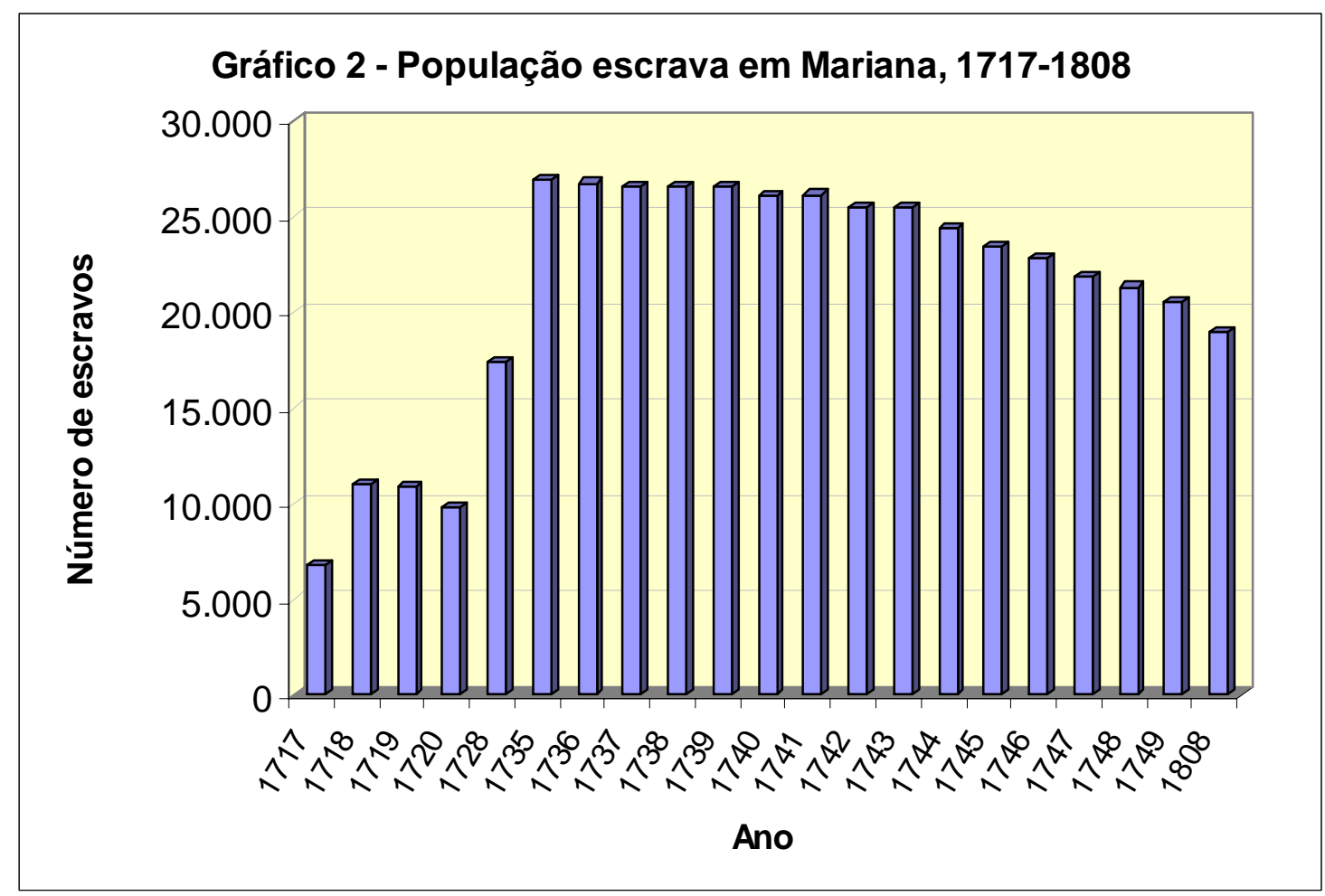

Fonte: BERGAD, Laird W. "Depois do boom: aspectos demográficos e econômicos da escravidão em Mariana, 1750-1808”. São Paulo: Estudos Econômicos, 24(3), Dez.1994, p. 499.

Os números comprovam que houve uma expansão da escravaria entre os anos de 1717 e 1735. O período compreendido entre 1735 e os primeiros anos da década de 1740 apresentam certa estabilidade nos dados. Esse quadro somente muda em meados da década de 1740, quando há uma queda gradual, representando uma diminuição de $20 \%$ do total dessa população. $^{46}$

Apesar da ausência de informações para a segunda metade dos setecentos, percebemos que o valor encontrado para os anos de 1749 e o de 1808 não se altera de forma brusca; há certa estabilidade entre a população escrava na passagem do século XVIII para o XIX, “com coeficientes anuais mínimos de declínio da população”. 47

Analisando os aspectos demográficos dos escravos, entre os anos de 1750 e 1808, Laird Bergad constatou certas mudanças estruturais no decorrer desse período. Em suas palavras,

\footnotetext{
${ }^{46}$ Bergad justifica esse fator se pautando nos estudos de Russell-Wood, que indicam a década de 1730 como o período em que se inicia a queda da exportação aurífera, resultando conseqüentemente na contração da atividade mineratória e na diminuição da importação de cativos para a região. Além disso, o autor salienta que a reprodução dos cativos foi encoberta pelo crescente número de alforrias no período em questão e "pela extrema distorção da razão de masculinidade em favor dos homens africanos importados para a capitania". BERGAD, Laird W. "Depois do boom: aspectos demográficos e econômicos da escravidão em Mariana, 1750-1808”. São Paulo: Estudos Econômicos, 24(3), Dez.1994, p. 498-500.

${ }^{47}$ BERGAD, “Depois do boom”, p. 500.
} 
No início da década de 1760, os africanos ainda compunham a esmagadora maioria dos escravos de Mariana (72\%), mas dali por diante os cativos nascidos no Brasil passaram a apresentar uma participação relativa constantemente crescente. Em 1795, os escravos crioulos estavam claramente em maioria (54\%), e ao entrar o século XIX mais de $60 \%$ dos cativos de Mariana eram nascidos no Brasil. ${ }^{48}$

Para esse autor, a hipótese mais plausível que explica o aumento de escravos nascidos na colônia em fins do século XVIII, é a reprodução natural desses sujeitos a partir da diminuição da importação de africanos, decorrente do declínio da mineração.

Outro processo concomitante ao crescimento da escravaria crioula é o aumento da população livre de cor na sociedade marianense em fins do século XVIII e início do XIX. Esse processo possivelmente teve seu primeiro impulso no período áureo da mineração, momento em que ocorreram as maiores taxas de alforria na região.

\subsection{Tipos de alforria e estimativas da população}

Os primeiros trabalhos sobre manumissão no Brasil surgiram a partir dos anos 1970 e hoje contamos com informações que abrangem as principais regiões da América Portuguesa e do Império do Brasil. ${ }^{49}$ As fontes investigadas são basicamente as cartas de alforria. Por

\footnotetext{
${ }^{48}$ BERGAD, “Depois do boom”, p. 501.

${ }^{49}$ MATTOSO, Kátia de Queiroz. "A propósito de cartas de alforria na Bahia, 1779-1850". Anais de História, Marília, n.4, p. 109-35, 1972, ver também "A Carta de Alforria”. In: Ser escravo no Brasil. São Paulo: Brasiliense, 1982; SCHWARTZ, Stuart B. "The Manumission of Slaves in Colonial Brazil: Bahia, 1684-1745". Hispanic American Historical Rewiew, v.54, n.4, p. 603-35, 1974. (Publicado também em Escravos, roceiros e rebeldes. Tradução: Jussara Simões. Bauru, São Paulo: EDUSC, 2001, p.171-218); MOTT, Luiz. "Cautelas de alforria de duas escravas na Província do Pará (1829-1846)”. Revista de História, São Paulo, 29 (I), p.3-24, 1976; SLENES, Robert. Demography and Economics of Brasilian Slavery: 1850/1888. 1975. Tese de doutorado, Universidade de Stanford; KARASCH, Mary Catherine. A vida dos escravos no Rio de Janeiro: 1808-1850. Tradução de Pedro Maia Soares. São Paulo: Companhia das Letras, 2000; KIERNAN, James. The manumission of slaves in colonial Brazil: Paraty, 1789-1822, Tese de Doutoramento em História (New York University, 1976); CUNHA, Manuela Carneiro da. "Sobre os silêncios da lei". In: Antropologia do Brasil. São Paulo: Brasiliense, 1986; CUNHA, Manuela Carneiro da. Negros, estrangeiros: os escravos libertos e sua volta à África, São Paulo: Corrupio, 1988; OLIVEIRA, Maria Inês Côrtes de. O liberto: o seu mundo e os outros, 1988; EISENBERG, Peter L. "A carta de alforria e outras fontes para estudar a alforria no século XIX” (cap. X, p.245254) e "Ficando livre: as alforrias em Campinas no século XIX" (cap. XI, p.255-314). Homens Esquecidos: escravos e trabalhadores livres no Brasil - Séculos XVIII e XIX. Campinas: Editora da UNICAMP, 1989; BELLINI, Ligia. "Por amor e por interesse: a relação senhor-escravo em cartas de alforria”. In: REIS, J. J. (org.). A escravidão e a invenção da liberdade: estudos sobre o negro no Brasil, São Paulo: Brasiliense, 1988, p.73-96; SILVA, Marilene Rosa Nogueira. Negro na rua. São Paulo: Editora Hucitec, 1988; ALGRANTI, Leila Mezan. O feitor ausente; estudo sobre a escravidão urbana no Rio de Janeiro de 1808 a 1822. Petrópolis: Vozes, 1988; LIMA, Lana Lage da Gama; VENÂNCIO, Renato P. "Alforrias de crianças escravas no Rio de Janeiro do século XIX”. Revista Resgate, n², 1991, p.26-34. FALCI, Miridan Britto Knox. "Alforrias de escravos: um estudo de relações sociais”. Revista da SBPH, Curitiba, n. 10, p.63-69, 1995; SOUZA, Laura de Mello e. "Coartação - problemática e episódios referentes a Minas Gerais no século XVIII". In: SILVA, Maria Beatriz Nizza da. (Org.). Brasil: colonização e escravidão. Rio de Janeiro: Nova Fronteira, 1999, p.275-295;
} 
meio de sua análise, é possível elucidar algumas das principais características dessa prática, bem como a sua incidência, as circunstâncias favorecedoras, o perfil do escravo libertado, e, principalmente, as formas encontradas para adquiri-las.

As abordagens sobre as alforrias são associadas às flutuações econômicas, às relações de poder e ao reconhecimento do escravo como agente negociador do processo. Muitos estudiosos também se baseiam em mais de um fator para tratar as questões da libertação. O ponto fundamental desses estudos é a compreensão da passagem da condição social de escravo para a de indivíduo livre.

Formas de alforria, concedidas por lei, só surgiram no final do século XIX. No período colonial e nas primeiras décadas do Brasil independente, as alforrias se davam no âmbito privado. A concessão da liberdade e sua revogação estavam diretamente submetidas ao consentimento dos proprietários. Isso não implica que o Estado estivesse alheio a esse processo, pois, de maneira geral, intervinha nas ocasiões que apresentavam atribulação à ordem social em questão. ${ }^{50}$ As circunstâncias se associavam a formas de amenizar possíveis revoltas escravas, ou até mesmo para espelhar laços de solidariedade frente às vítimas de maus tratos. ${ }^{51}$ Não havia nenhuma lei que obrigasse o senhor a ceder a carta de alforria a um escravo, ainda que o mesmo possuísse pecúlio para adquiri-la. ${ }^{52}$

Os elevados índices de população escrava em Minas Gerais, tanto na colônia como no império, atraíram também a atenção dos pesquisadores para os estudos relacionados ao processo de libertação. ${ }^{53}$ As pesquisas direcionadas à associação das taxas de alforrias com as

SILVA, Maria Beatriz Nizza da. “A luta pela alforria”. In: SILVA, Maria Beatriz Nizza da. (Org.). Brasil: colonização e escravidão. Rio de Janeiro: Nova Fronteira, 1999, p.296-307; FLORENTINO, Manolo. “Alforrias e etnicidade no Rio de Janeiro oitocentista: notas sobre pesquisa”. Topoi. Revista de História. Rio de Janeiro: Programa de Pós-Graduação em História Social da UFRJ/7 Letras, setembro 2002, n.5, p.9-40, SOARES, Márcio de Sousa. A remissão do cativeiro: alforrias e liberdades nos Campos dos Goitacazes, c.1750 - c.1830. Doutorado em História, Niterói, UFF, 2006.

${ }^{50}$ CUNHA, Manuela Carneiro da. "Sobre os silêncios da lei”, 1986, p.125. RUSSELL-WOOD, A. J. R. ““Acts of Grace': Portuguese Monarchs and Their Subjacts of African Descent in Eighteenth-Century Brazil.” Journal of Latin América Studies, Vol. 32, No.2, Maio 2000. p.309.

51 RUSSELL-WOOD, “Acts of Grace”, p.310-311. A interferência de monarcas não se restringe apenas aos casos de obtenção de alforria, mas em todas as situações de "conflitos de interesses dos grupos incoporados na colônia”. p. 324.

52 CUNHA, Antropologia do Brasil, p.123.

53 GONÇALVES, Andréa Lisly. “As margens da liberdade: Alforrias em Minas do século XIX”. Revista de História LPH, nº, 1996, p.200-208; RIBEIRO, Cotidiano e liberdade, 1996; PAIVA, Eduardo França. Escravos e libertos nas Minas do século XVIII; estratégias de resistência através de testamentos. São Paulo: Annablume, 1995; SOUZA, “Coartação”, 1999. HIGGINS, Kathleen J. “Licentious liberty” in a Brasilian gold-mining region: slavery, gender, and social control in eighteenth-century Sabará, Minas Gerais. University Park: The Pennsylvania State University Press, 1999; AGUIAR, Marcos Magalhães de. “A coartação: uma singularidade mineira no sistema de alforria colonial?” Revista da SBPH, Curitiba, n. 18, p. 77-91, 2000; MONTI, Carlo G. O processo da alforria; Mariana (1750-1779). Dissertação de Mestrado, FFLCH/USP, São Paulo, 2001; PAIVA, Eduardo França. Escravidão e universo cultural na colônia - 1716-1789. Belo Horizonte: Editora da UFMG, 2001. 
flutuações econômicas mostram que algumas regiões apresentaram características diferenciadas do restante da colônia. Contrariando as afirmações de Jacob Gorender ${ }^{54}$ sobre a multiplicação das alforrias em Minas Gerais no período de crise da mineração, os trabalhos de Andréa Lisly para Mariana, e o de Kathleen J. Higgins ${ }^{55}$, para Sabará, mostraram que essas duas regiões apresentaram dinâmica contrária, indicando números pouco mais elevados de libertações no período em que a exploração aurífera se encontrava em pleno vigor.

Cabe ressaltar que o período compreendido como de apogeu da exploração aurífera se deu entre os anos de 1735 e 1751, com um rendimento de 2.066 arrobas. ${ }^{56}$ Não há dúvidas quanto à riqueza gerada na região, porém, um conjunto de fatores associados às dificuldades com a manutenção dos escravos, às altas tributações e ao conseqüente investimento com técnicas extrativas, devido à exaustão do ouro de aluvião, definiu o que viria a ser a crise da mineração. Considerando que há disparidades quanto às delimitações desse período, adotaremos a seguinte indicação de Carla Almeida:

\begin{abstract}
Chamamos este período de auge minerador porque, apesar de a produção do ouro ter atingido seu ponto máximo entre 1735-1739, no decênio de 1750 a quota de 100 arrobas fora até excedida, na década seguinte a média anual caíra para 86 arrobas, mas somente entre 1774-1785 é que a queda seria de fato brutal: 68 arrobas de média anual. (...) apesar de decrescente, a produção aurífera ainda era suficientemente importante para manter a mineração como atividade principal e conservar a sua estrutura produtiva intacta, pelo menos até 1770 . Acreditamos que só em meados do decênio de 1770 esse declínio começa a provocar uma rearticulação econômica intencional que poderá ser percebida a partir de $1780 .^{57}$
\end{abstract}

O estudo de Andréa Lisly nos possibilita conhecer algumas das características das alforrias concedidas em Mariana em dois períodos específicos que marcam as alterações da economia mineradora - o momento de apogeu e o de decadência. Ao levantar 485 cartas de alforria correspondentes aos anos de 1735 a 1740 e 1770 a 1775, a autora se concentrou nas questões de gênero, origem do escravo e tipo de alforria. O período considerado por essa autora como o de decadência da mineração apresenta uma pequena divergência em relação à delimitação temporal adotada por Carla Almeida. Essa divergência, contudo, não se apresenta como obstáculo para o entendimento da dinâmica do processo de libertação. Apesar de não nos determos apenas aos aspectos econômicos que influenciaram as concessões de liberdade,

\footnotetext{
${ }^{54}$ GORENDER, Jacob. O escravismo colonial. São Paulo: Ática, 1980, p. 442.

${ }^{55}$ GONÇALVES, Andréa Lisly. As margens da liberdade: estudo sobre a prática de alforrias em Minas Gerais colonial e provincial. Tese de Doutorado, São Paulo: FFLCH/USP, 1999 e HIGGINS, “Licentious liberty”, 1999.

${ }^{56}$ SOUZA, Desclassificados do ouro: a pobreza mineira no século XVIII. Rio de Janeiro: Graal, 1982, p.22.

${ }^{57}$ ALMEIDA, Alterações nas atividades produtivas mineiras, p. 86-87.
} 
consideramos de fundamental importância o conhecimento de algumas das características desse processo. Para tanto, temos que nos reportar às amostragens levantadas pela autora no século XVIII:

\begin{tabular}{|c|c|c|c|c|c|c|c|}
\hline \multicolumn{7}{|c|}{ Tabela 2 - Alforrias em Mariana (1735-1740) e (1771-1775). } \\
\hline & \multicolumn{2}{|c|}{ Homens } & \multicolumn{2}{|c|}{ Mulheres } & \multicolumn{2}{|c|}{ Crianças } & Total \\
\hline Período & $\mathrm{N}^{\mathrm{o}}$ & \% Período & $\mathrm{N}^{\mathrm{o}}$ & \% Período & $\mathrm{N}^{\mathrm{o}}$ & $\%$ Período & \\
\hline $1735-1740$ & 32 & 13.2 & 123 & 50.8 & 87 & 36.0 & $\mathbf{2 4 2}$ \\
\hline $1770-1775$ & 68 & 36.4 & 101 & 54 & 13 & 6.9 & $\mathbf{1 8 2}$ \\
\hline
\end{tabular}

Fonte: GONÇALVES, Andréa Lisly. As margens da liberdade: estudo sobre a prática de alforrias em Minas Gerais colonial e provincial. Tese de Doutorado, São Paulo: FFLCH/USP, 1999, p.168, 169, 171 e 172.

Ao verificarmos esses resultados percebemos uma superioridade do número de alforrias para o primeiro período, o que nos leva a refutar as considerações acerca dessa prática como uma forma da classe senhorial se preservar do ônus gerado pelo declínio da atividade mineradora. Também reiteramos que as diferenças entre os valores não apresentam uma disparidade excessiva a ponto de considerarmos o fator econômico como determinante na concessão de liberdade.

A crise da mineração em Mariana não estimulou os senhores a concederem maior número de liberdade aos seus escravos. No levantamento das alforrias registradas em um período mais amplo (1750 a 1779), Carlo Monti define três momentos para essas concessões:

O primeiro terminou em 1755, encerrando uma tendência de crescimento nas concessões; o segundo momento teve seu fim em 1765 e foi marcado pela abrupta queda nas concessões, a partir do início do terceiro esboça-se uma pequena alta até 1770 , iniciadora do terceiro momento, para posteriormente retornar aos padrões de 1765, consumando a tendência de queda nas liberdades no termo e na cidade de Mariana. ${ }^{58}$

Sobre as questões de gênero, percebemos a superioridade do número de mulheres alforriadas em relação aos homens. No primeiro período a diferença se mostra ainda mais acentuada que no segundo. Essa tendência já foi registrada e explicada por outros pesquisadores para diferentes regiões e períodos, e no caso de Mariana, ela parece se confirmar.

\footnotetext{
${ }^{58}$ MONTI, O processo da alforria, p. 24. Em outro momento, esse mesmo autor nos dá referências mais precisas sobre a dinâmica das alforrias na segunda metade do século XVIII em Mariana. Constatou que no período compreendido entre os anos de 1750 a 1759 ocorreram na cidade um percentual de 36\%, enquanto 1760 a 1769 com $43 \%$, e 1770 a 1779 com $27 \%$ de alforrias.
} 
Tal incidência entre as mulheres se explicaria não apenas pela prostituição, concubinato ou matrimônio, sobretudo numa região carente de mulheres, como era o caso da capitania de Minas Gerais, mas também pelas oportunidades oferecidas pela economia urbana que ocupava um número significativo de pessoas do sexo feminino. ${ }^{59}$

É importante ainda considerarmos que as altas taxas de masculinidade nesse primeiro período são reflexo da complexa importação que privilegiava escravos como mãode-obra da economia mineradora. ${ }^{60}$ Já no segundo período, mesmo que inferior, o número de alforrias de homens parece se ampliar, diminuindo a disparidade entre os sexos. Para Andréa Lisly, um dos motivos que contribuiu para esse fator foi o "arrefecimento da capitania no tráfico internacional de escravos”. ${ }^{61}$

Os dados sobre as crianças são fundamentais aos estudos sobre as alforrias, mas nem todos os pesquisadores se dedicaram à análise desse segmento. Vale ressaltar que os valores encontrados para as três categorias (homens, mulheres e crianças), nos dois períodos, podem se aproximar do número real das concessões, mas não representam a sua totalização, uma vez que nem todas as libertações foram oficialmente registradas. Ao nos referirmos às alforrias de crianças, esses dados se tornam ainda mais imprecisos devido ao fato de muitas libertações em pia batismal ficarem restritas apenas aos registros dos livros eclesiásticos. Nesses casos, o assento de batismo é a única prova de que o escravo se tornou liberto quando criança. A partir dessas considerações, percebemos o quanto é expressivo o número de alforrias de crianças em Mariana, principalmente para o primeiro período, contabilizando 87 cartas, que representavam 36\% das concessões entre os anos de 1735 e 1740.

Com relação à origem desses alforriados, os dados corroboram com as observações da historiografia quanto à predominância dos escravos nascidos na colônia entre os indivíduos libertados. A classificação adotada para especificar a qualidade dos cativos foi a seguinte: africanos; crioulos - para os negros nascidos no Brasil; e mestiços - para mulatos e pardos. ${ }^{62}$ Para os anos de 1735 a 1740 foram concedidas 91 cartas de liberdade aos africanos, 31 para os crioulos e 84 para os mestiços. No segundo período, 1770 a 1775, contamos com 74 cartas para os africanos, 28 para os crioulos e 51 para os mestiços. Mesmo os africanos apresentando

\footnotetext{
${ }^{59}$ GONÇALVES, As margens da liberdade, p.166.

${ }^{60}$ GONÇALVES, As margens da liberdade, p. 168.

${ }^{61}$ GONÇALVES, As margens da liberdade, p. 171.

${ }^{62}$ Ver também MONTI, O processo da alforria, p. 39. Esse autor também adotou a mesma classificação para os alforriados encontrados e verificou um percentual de 35\% para os crioulos, $20 \%$ para mestiços e $43 \%$ para os africanos.
} 
um número menor de alforrias para os dois períodos, percebemos que "a nacionalidade do cativo pouco contou nos cálculos do proprietário”. ${ }^{63}$

Infelizmente não dispomos de dados mais precisos sobre a população liberta de Mariana no século XVIII. Apenas nos é permitido perceber o percentual de pessoas libertadas nas duas amostragens exibidas por Andréa Lisly. ${ }^{64}$ Observando os dados de 1735 a 1740, percebemos um total de 242 alforrias concedidas, que correspondem a uma aproximação de 40 alforrias anuais. Para o segundo período, 1770 a 1775 contamos com 182 alforrias, que correspondem a 30 alforrias concedidas anualmente.

Associando os dados sobre população escrava trazidos por Laird Bergad ao número de alforrias registrado por Andréa Lisly referentes à primeira metade do século obteremos uma aproximação da porcentagem das libertações concedidas em Mariana nesse mesmo período. Noutras palavras, considerando a média da população escrava (26.564 escravos), com a média das alforrias concedidas (40 alforrias), podemos inferir que a taxa de escravos libertados representou apenas $0,15 \%$ dos escravos existentes em Mariana. Mas essas são as alforrias registradas em cartório e que ainda se encontram nos arquivos da cidade; sabemos, por exemplo, que houve um elevado número de libertações concedidas em testamentos e pias batismais. Carlo Monti verificou entre os anos de 1750 a 1779, 243 alforrias concedidas em testamentos, o que representa 8,3 alforrias anuais.

Por falta de dados mais precisos não podemos inferir seguramente o percentual de indivíduos libertados, mas, pelas aproximações observadas com os dados da primeira metade do século, percebemos que a taxa de libertações em Mariana não se aproximou do cálculo fornecido por Kathleen Higgins para a colônia portuguesa. ${ }^{65}$ Não obstante, é importante reiterarmos alguns aspectos levantados anteriormente, como a perda de dados, a possibilidade de parte das alforrias não terem sido registradas em cartório e a presença de registros nos assentos de batismo, que podem contribuir para o aumento dessas taxas, mas que não foram apreendidos pelos autores aqui abordados.

\footnotetext{
${ }^{63}$ MONTI, O processo da alforria, p.178.

${ }^{64}$ Além de se tratar de uma amostragem, é importante salientarmos que os dados apresentados no referido trabalho condizem com uma aproximação das efetivas taxas de alforrias no século XVIII, uma vez que muitos desses papéis não chegaram a ser registrados em cartório, ou ainda se considerarmos a perda de muitos registros, realidade condizente com a maior parte dos arquivos brasileiros, seja administrativo, cartorário ou eclesiástico.

${ }^{65}$ Russell-Wood chamou a atenção para as taxas anuais apresentadas por Kathleeen Higgins sobre a incidência de libertações anuais no Brasil colônia, especificadas entre os valores de 0,33\% a 1\%, que segundo a autora, compunham uma fração exígua do total da população escrava da região. RUSSELL-WOOD, Escravos e libertos no Brasil colonial, p. 309; HIGGINS, Kathleen J. 'Gender and the manumission of slaves in Colonial Brazil: the prospects for freedon in Sabará, Minas Gerais, 1710-1809'. Slavery and Abolition, 18:2 (agosto de 1997), p.11, ver também nota 47, p. 26.
} 
Para entendermos melhor o processo da alforria no século XVIII, é imprescindível conhecermos as modalidades praticadas na região em questão. Não se trata aqui de analisar as relações de caráter paternalista ou de reconhecer o escravo como agenciador do processo de libertação; queremos apenas especificar os meios que permitiram ao cativo o acesso à sua liberdade.

Das alforrias registradas em cartório, a historiografia anota basicamente dois tipos: as incondicionais e as condicionais. ${ }^{66}$ As classificadas como incondicionais eram as “gratuitas”, realizadas sem a contrapartida monetária, geralmente concedidas como formas de "agradecimento" do senhor ao escravo, pelo fato desse último lhe ter servido conforme desejava, ou seja, pelos "bons serviços prestados”. Libertações concedidas sem ônus ao escravo também podem ser encontradas nos registros eclesiásticos, especificamente nos testamentos e nos assentos de batismos.

Em alguns testamentos, os senhores concediam alforria a seus escravos e ainda deixavam-lhes uma quantia em dinheiro. Mesmo que esse valor não fosse muito significante, grosso modo, essa prática representaria um auxílio no começo da nova vida desse liberto. No segundo caso, trata-se de alforrias de pia batismal, também muito freqüentes no período colonial. Quando padrinho, o senhor tendia a alforriar seu escravo, fosse como forma de se precaver das despesas com a criança, ou pelo reconhecimento de paternidade. ${ }^{67}$ Em outro casos, essas modalidades podem indicar relações de afetividade entre as partes, mas que não deixam de transparecer normas de comportamento de subserviência do escravo, ainda no período de cativeiro, que, por vezes, perpetuariam-se por toda a vida desse indivíduo enquanto liberto.

As alforrias condicionais encontradas em Mariana no período colonial eram marcadas pela presença do dinheiro, de serviços prestados, ou até mesmo pela presença das duas categorias simultaneamente. As alforrias "pagas” se caracterizavam pelo autopagamento, pagamento por terceiros ou coartação. Quando a escolha fosse pelo autopagamento, tudo indica que a economia amealhada por um cativo, no decorrer de toda a sua vida, seria entregue em troca da tão sonhada liberdade, apontando para um início de vida, sob nova condição social, bastante desprovido de recursos materiais. ${ }^{68}$

A modalidade compreendida como pagamento por terceiros é importante porque nos permite verificar a presença de laços familiares entre o pagador e o escravo que se queria

\footnotetext{
${ }^{66}$ GONÇALVES, “As margens da liberdade”, p.202-208. Ver também MONTI, O processo da alforria, p.124.

${ }^{67}$ LIMA; VENÂNCIO, “Alforrias de crianças escravas”, p.30.

${ }^{68}$ GONÇALVES, As margens da liberdade, p. 18.
} 
libertar, ou simplesmente a existência de relações afetivas entre os mesmos. Os casos mais comuns de manumissão envolvendo família em Mariana não se referiam à libertação simultânea de mães e seus filhos, mas sim de concessões de irmãos, prevalecendo a incidência de meninos contemplados. Conforme especificou Carlo Monti,

Alforrias dos infantes se caracterizaram por libertar aqueles que viviam com ou próximos às mães. Quando moravam com as progenitoras essas, na maior parte, eram escravas do mesmo senhor que somente libertou os filhos delas. Estes continuariam a viver próximo das mães cativas. ${ }^{69}$

Os dados levantados por meio das cartas de alforrias registradas em cartório nos permitem conhecer as principais modalidades utilizadas pelos escravos de Mariana na obtenção de sua liberdade, em dois períodos do século XVIII.

\begin{tabular}{|c|c|c|c|c|c|c|}
\hline \multicolumn{6}{|c|}{ Tabela 3 - Alforrias gratuitas e condicionais em Mariana (1735-1740) e (1771- } \\
1775). \\
\hline Período & Gratuita & $\begin{array}{c}\text { Auto } \\
\text { Pagamento }\end{array}$ & $\begin{array}{c}\text { Prestação de } \\
\text { serviços }\end{array}$ & Coartação & $\begin{array}{c}\text { Compra por } \\
\text { terceiros }\end{array}$ & $\begin{array}{c}\text { Sem } \\
\text { registro }\end{array}$ \\
\hline $1735-1740$ & 9 & 56 & 3 & 30 & 32 & 108 \\
\hline $1770-1775$ & 17 & 40 & 15 & 22 & 10 & 47 \\
\hline Total & 26 & 96 & 18 & 52 & 42 & 155 \\
\hline
\end{tabular}

Fonte: GONÇALVES, Andréa Lisly. As margens da liberdade: estudo sobre a prática de alforrias em Minas Gerais colonial e provincial. Tese de Doutorado, São Paulo: FFLCH/USP, 1999, p.371.

Contando que alguns registros não puderam ser catalogados por mau estado de conservação, conforme informou a autora, temos então 398 casos, sendo 241 para o primeiro período e 157 para o segundo. As alforrias sem registros são predominantes, seguidas pelo auto-pagamento e pelas coartações. É importante perceber que as modalidades que envolvem ônus ao escravo são superiores no período compreendido pelo auge da mineração, somando 118 para o primeiro período e 72 para o segundo. A predominância dessas modalidades nos indica que houve uma presença marcante de escravos que foram capazes de acumular pecúlio suficiente para a compra de sua libertação. Esse aspecto guarda relações com as atividades que desenvolviam, e que, provavelmente, contribuíram de maneira imediata na obtenção de recursos que proveram suas necessidades básicas, enquanto libertos. Apesar do autopagamento representar a modalidade mais escolhida pelos escravos, sabemos que a coartação também foi muito difundida no período colonial.

\footnotetext{
${ }^{69}$ MONTI, O processo da alforria, p. 49-50.
} 
O número de mulheres é predominante nas concessões de alforrias, mas, ainda assim, os homens se apresentavam como os maiores negociadores, ou seja, aqueles que mais se libertaram por meio de alforrias onerosas. As mulheres eram mais contempladas com as alforrias gratuitas. Para Carlo Monti,

Provavelmente os senhores recompensaram suas serviçais de casa, dando a liberdade, eram elas mulheres com as quais tinham mais contato. Para os homens que foram libertos a relação demonstrou-se mais comercial como o desenrolar de um acordo, onde o escravo não geraria problemas ao desenvolver o seu trabalho e o senhor aceitaria um pagamento legítimo. ${ }^{70}$

Os altos índices de alforrias pagas nas regiões urbanas mineiras também foram associados à maior facilidade que o escravo tinha em juntar o pecúlio para a quitação de sua liberdade. Em confrontação com a sociedade escravista rural, os artifícios encontrados no ambiente urbano privilegiavam os escravos na conquista da alforria por meio do desenvolvimento de atividades associadas ao ambiente em questão. $\mathrm{O}$ indicativo predominante das alforrias onerosas guarda alguma relação com a atividade desenvolvida pelo indivíduo ainda no período de cativeiro. No caso das coartações, essa relação se torna ainda mais aproximada, uma vez que a liquidação do valor estipulado poderia variar entre dois e oito anos, sendo os períodos mais freqüentes de quatro a seis anos. ${ }^{71}$

A historiografia nos permite perceber nos casos em que os próprios escravos foram os responsáveis pela compra de sua liberdade, ou auto-pagamento, a existência dos artifícios que facilitaram a acumulação de bens por parte desses indivíduos. Os recursos usados eram, basicamente, a comercialização de alimentos e execução de atividades extras. Esses eram os negros de ganho e as negras de tabuleiro. O negro de ganho era aquele considerado “autônomo”, que trabalhava por conta própria e, no fim do dia, retornava à casa de seu senhor levando uma quantia pré-determinada. ${ }^{72}$ Essa quantia era parte daquilo que havia conseguido com o esforço de seu trabalho; o que sobrava do pagamento ao senhor pertencia a ele.

As negras de tabuleiro eram aquelas mulheres que trabalhavam vendendo produtos comestíveis a mando de suas senhoras, quando escravas, ou por conta própria, quando libertas. Essas vendedoras poderiam ter um ponto específico ou ainda circular pela cidade, sobretudo nas áreas de extração de ouro e diamantes, oferecendo suas iguarias à população. Ainda que não se possa generalizar, sabemos que sérias acusações sobre elas pesaram desde o

\footnotetext{
${ }^{70}$ MONTI, O processo da alforria, p. 86.

${ }^{71}$ MONTI, O processo da alforria, p. 125.

${ }^{72}$ SILVA, Negro na rua, p.87.
} 
início do século XVIII. Em 1715, por meio das Posturas da Câmara da Vila do Carmo, foram proibidas de comercializarem seus produtos nas proximidades das lavras, pois eram suspeitas de incitação de desordem, desvio clandestino de ouro, além de servirem de intermediárias entre a população urbana e os escravos fugidos, ou quilombolas. ${ }^{73}$ Seja como for, ela acabavam por avultar o comércio ambulante da região.

A historiografia também nos mostra que, com o processo de urbanização em Minas, a diversificação das atividades contribuiu para uma ampla flexibilidade social. ${ }^{74}$ A questão da liberdade de se movimentar e de praticar diferentes ofícios está diretamente relacionada às necessidades das atividades executadas no meio urbano. Tais atividades podem ter contribuído para que muitos escravos conseguissem meios de obter a alforria. Na Capitania das Minas, entre os anos de 1735 a 1749, estima-se que os libertos compunham aproximadamente 1,4\% dos indivíduos de origem africana, ao passo que, em 1786 representavam 41,4\% desses, e 34\% da demais população. ${ }^{75}$ Em consonância, a cidade de Mariana apresentou um aumento que pudemos verificar a partir dos óbitos das pessoas que faleceram na segunda metade do século. O percentual de libertos falecidos entre os anos de 1751 a 1800 foi de 11,2\% com relação ao restante da população, os escravos representaram 43,28\%. Esse conjunto de pessoas somou quase $55 \%$ do total de falecidos da cidade. Essas taxas de falecimento de libertos foram aumentando ao longo das décadas, representando consecutivamente $4,7 \%, 6,5 \%, 12,1 \%, 13,2 \%$ e $15,2 \%$ entre 1751 e 1800 , o que indica que essa população continuou crescendo no decorrer do século XVIII.

Ainda que os dados presentes na historiografia apontem para índices de libertações superiores na primeira metade do século, mais especificamente entre os anos de 1735 e 1740 do que entre 1770 e 1775, essas referências são amostragens de quadros bem específicos. Nossos dados dão conta de um período maior, mas se referem ao momento de morte dos emancipados. Sem dúvida alguma, os índices de manumissão da primeira metade dos setecentos contribuíram de maneira especial para o crescimento dessa classe e seus descendentes no período seguinte. ${ }^{76}$ Resta-nos, portanto, tentar traçar algumas características dessas pessoas que conpuseram o conjunto de egressos do cativeiro na mesma região.

\footnotetext{
${ }^{73}$ FIGUEIREDO, O avesso da memória, p.123.

74 LUNA, Francisco Vidal, COSTA, Iraci Del Nero da. “A presença do elemento forro no conjunto de proprietários de escravos”. Ciência e Cultura, 32: 1980, p. 836.

${ }^{75}$ RUSSEL-WOOD, Escravos e libertos no Brasil colônia. Tradução de Maria Beatriz Medina. Rio de Janeiro: Civilização Brasileira, 2005, p.166.

${ }^{76}$ Ao verificarmos o aumento do número de mortes de libertos, em fins do século XVIII em Mariana, conseqüentemente consideramos que também houve um crescimento desse segmento da população. Portanto, ainda que os dados de Andréa Lisly apontem para maior número de alforrias na amostragem que cobriu os anos
} 


\subsection{Traços sobre a procedência da população liberta}

Ao mencionarmos o termo "escravo", parece-nos, a príncípio, que estamos nos referindo basicamente a pessoas provenientes do continente africano que desembarcaram em portos coloniais brasileiros por motivo da imigração forçada, em um período que abarcou mais de 300 anos. No entanto, não podemos nos esquecer que muitos foram os escravos nascidos na América Portuguesa, que também se movimentaram em função do tráfico interno. A distribuição terrestre de cativos se caracterizou tanto pelo transporte de africanos dos portos coloniais brasileiros para o interior como de escravos crioulos vendidos a regiões distantes do local de seu nascimento. Para a província de Minas Gerais, essa foi a forma de abastecer as regiões do garimpo e mineração no decorrer do século XVIII, e das regiões do sul, quando a economia se voltou para a subsistência, no final desse mesmo século e decorrer do seguinte. ${ }^{77}$

No que concerne aos africanos, o movimento interno de escravos sempre esteve vinculado ao tráfico transatlântico. O destino desses homens estaria previamente traçado, ou simplesmente era definido nos próprios portos de desembarque e em mercados destinados a esse tipo de negócio. Nunca se saberá ao certo, quantos africanos foram desembarcados nas Américas. De maneira geral, adota-se como referência a aproximação de 9,5 a 10 milhões de pessoas que atravessaram o atlântico em um constante fluxo de navios negreiros destinados ao Novo Mundo, entre os séculos XVI e XIX. Desse valor, estima-se que 40\% foram enviados à América Portuguesa. ${ }^{78}$ A precisão das informações sobre esses traficados escapa devido a lacunas das informações referentes aos conjuntos dos registros existentes, mas sabe-se que em sua maioria eram homens, seguido de um número inferior de mulheres e crianças. $^{79}$ No entanto, a característica que se apresenta ainda mais controversa talvez seja a que se refere ao local de origem dessas pessoas.

Os primeiros contatos dos portugueses com a costa africana se deram ainda no século XV, embora não se possa traçar o conhecimento que os mesmos tinham sobre a

de 1735 a 1740, em detrimento dos valores encontrados para 1770 a 1775 , é importante considerarmos a necessidade de um estudo que aponte dados mais completos dessa prática na referida cidade.

${ }^{77}$ FLORENTINO, Em costas negras, p. 37-39.

78 Segundo informações adotadas por Manolo Florentino, ao Caribe inglês cabia a segunda maior área de recolhimento desses africanos, que ainda assim se referia a menos da metade do valor considerado para os portos coloniais brasileiros. FLORENTINO, Em costas negras p. 23.

${ }^{79}$ As informações sobre idades são muito limitadas, mas no que tange às crianças, houve referências mais específicas em determinados períodos, que pareciam se relacionar a questões inerentes aos impostos pagos pelo tráfico. Os registros as definiam como "crias de pé”, que por vezes se subdividiam em "meio direito" e "livres", para designar a isenção do pagamento dos impostos; e por fim, “crias de peito”. KLEIN, Herbert S. "A demografia do tráfico atlântico de escravos para o Brasil”. Estudos Econômicos. São Paulo, 17 (2):129-149, maio/ago. 1987, p.137-140. Ver tabela 8, página 140. 
extensão desse território. ${ }^{80}$ Foram primeiramente movidos pelo descobrimento da rota em direção às Índias, fator que não impediu que despertassem a curiosidade e interesse por uma região promissora quanto à sua potencialidade comercial. ${ }^{81}$ À medida que foram avançando e se instalando, também deram conta de que os nativos seriam uma das mais importantes mercadorias para negociações feitas naquele local.

O tráfico transatlântico mostrou-se a príncipio uma atividade substancialmente portuguesa, que remonta ao século XVI, mas até a sua definitiva proibição, em 1850, várias nações européias e comerciantes americanos, sobretudo baianos e cariocas, se incorporaram a essa atividade. Foram embarcados para a colônia portuguesa escravos da África Ocidental, denominados como sudaneses, e da África Central, como bantos, ${ }^{82}$ mas houve primazia de uns em detrimento dos outros em períodos específicos, que grosso modo podem ser explanados a partir de "ciclos". O primeiro ocorreu no século XVI e teve predominância de negros oriundos da região da Guiné; o segundo no século XVII, do Congo e Angola; o terceiro no século XVIII, da Costa da Mina; e o quarto, referente ao século XIX, de diversas procedências, com tendência maior para negros de Angola e Moçambique. ${ }^{83}$ Não obstante, os dados apresentados por Herbert Klein, sobre as origens dos africanos desembarcados no Brasil entre os anos de 1701 a 1810, apontam para 605.500 procedentes da Costa da Mina e 1.285.900 de Angola, perfazendo um total de $1.891 .400 .^{84}$

O porto carioca teria absorvido maior parte dessa importação, indicando aproximadamente 730 mil africanos entre os anos de 1701 a 1790, muitos dos quais foram distribuídos posteriormente para o interior da colônia. ${ }^{85} \mathrm{O}$ que proporcionou a introdução desse volume considerável de mão-de-obra escrava foi, certamente, a descoberta do ouro nas Minas Gerais, local para onde foi enviada grande parte desses adventícios. ${ }^{86}$

\footnotetext{
${ }^{80}$ SOARES, Mariza de Carvalho. "Descobrindo a Guiné no Brasil colonial”. RIHGB, Rio de Janeiro, 161(407) 71-94, abr./jun. 2000, p. 72.

${ }^{81}$ OLIVEIRA, Maria Inês Côrtes de. ““'Quem eram os “negros da Guiné?” A origem dos africanos na Bahia”. Afro-Ásia, 19/20, 37-73, (1997), p.38.

${ }^{82}$ Os primeiros eram os denoiminados como mina, nagô, cobu, lada, guiné, courano, sabaru, nagô, manding, tibu, dentre outos. Os povos bantos eram: angola, congo, benguela, cassange, rebolo, dentre outros.

${ }^{83}$ MATTOSO, Kátia de Queiroz. Ser escravo no Brasil. São Paulo: Ed. Brasiliense, 1982, p. 22-23. Maria Inês também emprega o termo ciclos, recuparando a idéia de autores como Viana Filho e Pierre Verger para o tráfico da Bahia. OLIVEIRA, “Quem eram os “negros da Guiné?”, p.40.

${ }^{84}$ KLEIN, “A demografia do tráfico atlântico de escravos para o Brasil”, p. 135. O autor informa que os dados por ele detalhados eram estimativas retiradas do trabalho de Philip Curtin de 1969, recuperados pelo trabalho de 1949 de Goulart e posteriormente modificados por Birmingham em 1966. BIRMINGHAN, David. Trade and Conflit in Angola: The Mbundu and their Neighbours under the Influence of the Portuguese 1483-1790. Oxford Press, 1966; CURTIN, Philip D. The Atlantic Slave Trade: A Census. Wisconsin, University of Wisconsin Press, 1969 e GOULART, Maurício. Escravidão Africana no Brasil. (das Origens à Extinção do Tráfico). $1^{\text {a }}$ ed. São Paulo, 1949.

${ }^{85}$ FLORENTINO, Em costas negras, p. 64.

${ }^{86}$ SOARES, “Descobrindo a Guiné no Brasil colonial”, p. 82; FLORENTINO, Em costas negras, p. 37.
} 
Escravos procedentes de várias regiões da África entraram em Minas Gerais, mas houve predominância daqueles da Costa da Mina, localizada na região ocidental. ${ }^{87}$ Alguns autores contemporâneos justificavam essa predileção a partir de fatores como a inteligência e resistência física. Acreditava-se que os mina eram mais aptos ao trabalho do que os bantos, não só pelas suas precedentes experiências com a mineração, mas ainda por serem mais robustos e conseqüentemente, mais resistentes às doenças que os acometiam na colônia portuguesa. Os bantos, por sua vez, eram vistos pelos mesmos como mais adaptáveis e menos inclinados a atitudes de rebeldia e inconformismo como os outros. ${ }^{88}$ Essas imagens podem ter se cristalizado ao longo dos séculos em função da conjuntura do tráfico predominante naquele período. Tratava-se da “propaganda” a cargo da oposição de valores entre os comerciantes baianos e os portugueses. Essa rivalidade surgiu no final do século XVII e persistiu em todo o século XVIII, quando os primeiros atuavam na Costa da Mina, comerciando fumo sem intervenção dos portugueses, e, esses então, controlavam o tráfico de Angola em condomínio com os cariocas. ${ }^{89}$ De todo modo, eram denominados como "minas" a partir de um costume português de "chamar todos os que vinham da África Ocidental ou da Costa da Guiné da Mina” ou "num sentido mais estrito, para escravos exportados da Costa da Mina”. 90

Ao desembarcarem na colônia portuguesa, geralmente eram identificados com nome de sua nação de origem, legitimado a partir da doutrinação cristã, quando era ministrado o primeiro sacramento, o batismo. Esse ritual poderia ocorrer ainda nos portos africanos, mas, ao que se sabe, seu registro garantia a posse sobre um escravo, antes mesmo de uma escritura pública. ${ }^{91}$ A legislação eclesiástica ordenava que todo proprietário levasse em pia batismal um cativo adquirido. O prazo para esse ato não poderia ultrapassar o período posterior a seis meses da compra efetivada. ${ }^{92}$ A denominação da nação, portanto, poderia se referir ao local de

\footnotetext{
${ }^{87}$ RUSSELL-WOOD, Escravos e libertos, p.55; BERGAD, Escravidão e História Econômica, p. 229.

88 ANTONIL, André João. Cultura e Opulência no Brasil. $3^{\mathrm{a}}$ ed. Belo Horizonte: Itatiaia; São Paulo: Edusp, 1982, p.89.

${ }^{89}$ OLIVEIRA, “Quem eram os negros da Guiné?”, p.45-47; REGINALDO, Lucilene. Os Rosários dos Angolas: irmandades negras, experiências escravas e identidades africanas na Bahia setecentista. Tese de doutorado. IFCH/Unicamp, Campinas., 2005, Capítulo 4.

${ }^{90}$ KARASCH, Vida do escravo no Rio de Janeiro, p. 63.

${ }^{91}$ Os escravos batizados na Vila do Carmo no ano de 1723 apresentam algumas designações que podem ser associadas nações, terras e outros designativos de origem, que são: Mina, Benguela, Angola, Congo, Crioula, Cabo Verde, Cobu, Monjolo, Moçambique, Courana, Carabari, Xamba, Massangano, Loango, Xará, Ganguela, São Tomé, Rebolo, Ardra, Barba, China, Nagô, Bamba, Clava, Baqua, Ambaqua, Foam, Mina Fon, Fon, Fula, Bandarra, Morangue, Nagoâ, Nagom, Anago, Garunga, Tibu, Mina Grande, Branu ou Buanu, Quissamã e Gola. MAIA, Moacir Rodrigo de Castro. “ ‘À moda de sua terra’: identidade étnica e parentesco espiritual entre escravos couranos na Mariana setecentista (1715-1750)”. Anais do XII Seminário sobre Economia Mineira, 2006, p.8.

92 CONSTITUIÇÕES primeiras do acerbispado da Bahia, feitas e ordenadas pelo ilustríssimo e reverendíssimo senhor Sebastião Monteiro da Vide bispo do dito arcesbispado, e do Conselho de sua magestade, propostas e
} 
origem, ou simplesmente indicar o porto de embarque na África, e não tratar propriamente de grupos étnicos. $^{93}$

Outra projeção se faz para além do âmbito do tráfico atlântico; acredita-se que a denominação “nação mina” também teria sido “incorporada pelos grupos organizados em cativeiro e servindo como ponto de referência para o reforço de antigas fronteiras étnicas e territorias, e ainda para novas configurações identitárias, sejam elas étnicas, ou não”. ${ }^{94} \mathrm{~A}$ partir desse viés interpretativo, a identificação construída na diáspora teria conduzido a organização de determinados grupos no quadro social da colônia, como, por exemplo, as irmandades leigas católicas, corporações paramilitares e até mesmo relações de parentesco. ${ }^{95}$ Essa seria uma reorganização possivelmente presente não só entre os cativos, mas também entre os grupos egressos do cativeiro.

É importante ressaltar que todo africano que desembarcasse nos portos coloniais receberia um prenome acompanhado de um termo indicativo de origem, enquanto um escravo nascido na colônia teria uma designação indicativa de sua cor. ${ }^{96}$ A partir do momento em que ocorresse a mudança de sua condição social, essa denominação também se alteraria, pois seria acrescentado um sobrenome, geralmente transplanatado daquele que pertencia ao seu último senhor. ${ }^{97}$

aceitas em o synodo diocesano que o dito senhor celebrou em 12 de junho do anno 1707. São Paulo: Typografia, 2 de dezembro, 1853. Livro I, Título XIV.

${ }^{93}$ KARASCH, Mary Catherine. A vida dos escravos no Rio de Janeiro, p. 50. BERGAD, Escravidão e História Econômica, p. 227. SOARES, Carlos Eugênio Líbano. Capoeira escrava e outras tradições rebeldes no Rio de Janeiro (1808-1850). Unicamp: Ed. Da Unicamp, 2001, p.125. RUSSELL-WOOD, A. J R. "Através de um prisma africano: uma nova abordagem ao estudo da diáspora africana no Brasil colonial.” Tempo, 12, 2001, p. $12-13$.

${ }^{94}$ SOARES, Mariza de Carvalho. "A 'nação' que se tem e a 'terra' de onde se vem: categorias de inserção social de africanos no Império português, século XVIII”. Estudos Afro-Asiáticos, Ano 26, n²6, 2004, p.308. O termo "grupos de procedência" é empregado a partir do conceito do antropólogo norueguês Fredrik Barth. Cf. BARTH, Fredrik. Os grupos étnicos e suas fronteiras. In: O guru e o iniciador e outras variações antropológicas. Rio de Janeiro: Contra Capa, 2000. p. 25-67.

${ }^{95}$ SOARES, “A 'nação' que se tem e a 'terra' de onde se vem”. SILVA, Luiz Geraldo. "Da festa à sedição. Sociabilidades, etnia e controle social na América Portuguesa (1776-1814)”. In: JANCSÓ, István; KANTOR, Íris (orgs.). Festa: Cultura \& Sociabilidade na América Portuguesa. São Paulo: Hucitec: Editora da Universidade de São Paulo: Fapesp: Imprensa Oficial, volume I, 2001, p.313-335. OLIVEIRA, Maria Inês Côrtes de. "Viver e morrer no meio dos seus. Nações e comunidades africanas na Bahia do século XIX". Revista USP, São Paulo (28), dez/fev. 95/96. PINHEIRO, Fernanda Aparecida Domingos Pinheiro. Confrades do Rosário: sociabilidade e identidade étnica em Mariana - Minas Gerais (1745-1820). Niterói: ICHF/UFF, Dissertação de Mestrado, 2006.

${ }^{96}$ FURTADO, Júnia Ferreira. Chica da Silva e o contratador de diamantes. O outro lado do mito. São Paulo: Companhia das Letras, 2003, p. 49-553.

${ }^{97}$ Para Manoela Carneiro da Cunha, essa prática tendia a "tranformar o escravo em um cliente". CUNHA, Negros, estrangeiros, p. 51. Essa prática ainda foi vista por Márcio Soares como uma apropriação de nova identidade assumida a partir da alforria, que de certa forma tendia a prestigiar os antigos senhores, SOARES, $A$ remissão do cativeiro, p.211 e 214. 
Algumas informações sobre a procedência dos libertos de Mariana da segunda metade do século XVIII também foram identificadas após a leitura dos assentos de óbitos, registros de testamentos e ações cíveis encontradas. Foram identificadas denominações diferenciadas, mas que, em alguns casos, estão relacionadas a lugares em comum. A indicação mais freqüente é a referência genérica "preta mina” e "preto mina”, muito utilizados tanto nos registros cartoriais, como administrativos e eclesiásticos.

Entre os que faleceram na segunda metade do século XVIII, percebe-se a predominância de pretos, que pode ser entendida como africanos. ${ }^{98}$ Do total de 795 registros de libertos, esses somam 461. No entanto, apenas 49 apresentam indicação de procedência, sendo 34 minas, 12 angolas, 2 couranos e 1 congo. Em seguida, vinham os pardos, com 138, os crioulos com 135 e cabras com apenas 9. Os 52 assentos restantes não traziam nenhum tipo de informação. ${ }^{99}$

Os libertos testadores totalizaram 91 pessoas $^{100}$; seus registros apresentam descrições mais detalhadas, por isso assinalam maiores variações das informações. Os procedentes da África Ocidental foram descritos como “da Costa da Mina”, “do Gentio da Guiné”, ou “da Costa da Mina e Gentio da Guiné”, “de nação da mina” e representam 70 casos. As demais áreas foram bem inferiores, sendo 3 de “Angola”, 1 da "Costa de Angola”, 1 de “Luanda” e 3 do “Cabo Verde”. Uma indicação se referia a Portugal e outra a Pernambuco. Apenas 4 registros indicavam libertos nascidos na região de Mariana, sendo 2 em Antônio Pereira, 1 em Itaverava e 1 em São Sebastião. ${ }^{101}$ Dos dados que não apresentavam informações mais precisas, dois são indicados como africanos, um "preto forro" e uma "preta forra”, em seguida uma era “crioula forra” e o restante sem referência que se possa considerar a procedência.

As informações levantadas a partir das ações cíveis apontam para resultados diferenciados no que tange à natureza da ação. Enquanto os pretos são mais freqüentes nas

\footnotetext{
${ }^{98}$ CASTRO, Hebe Maria Matos de. Das cores do silêncio: Os significados da liberdade no sudeste escravista. Rio de Janeiro: Nova Fronteira, 1998, p. 34-35. BARICKMAN, B.J. "As cores do escravismo: escravistas “pretos”, "pardos”, e “cabras” no Recôncavo baiano, 1835”. Revista CEDHAL (População e família), №2, 1999, p.7-59.

${ }_{99}$ As mulheres compunham 465 registros, enquanto os homens representavam 330.

100 Além do levantamento dos testamentos, consta nessa soma todas as cópias de testamento encontradas anexadas aos registros de inventários. Os registros de inventários somam 41, desses, apenas 12 não fizeram suas disposições testamentárias, ou não constava no inventário. Os testamentos somam 98 documentos, no entanto 6 haviam sido levantados no próprio inventário. No que diz respeito ao sexo, temos nos testamento 62 mulheres e 29 homens, e inventários de 26 mulheres e apenas 12 homens.

${ }^{101}$ Sete registros não traziam informações mais precisas e um não foi possível identificar por deterioração do documento.
} 
ações que envolviam questões referentes a cobranças, os nascidos na colônia predominavam naquelas relacionadas à questão da liberdade. ${ }^{102}$

Mesmo dispondo de informações limitadas, é importante lembrar que entre as existentes, há predominância de africanos, sobretudo da Costa da Mina. Apesar dos registros sobre o tráfico para o Brasil do século XVIII apontarem altos índices de africanos da África Central $^{103}$, houve predominância de africanos da África Ocidental nos registros sobre libertos. Podemos pensar que grande parte dos libertos de Mariana na segunda metade desse mesmo o século conheceu a experiência do tráfico. Algumas disposições testamentárias conduziam para esse fator.

Os testamentos certamente não eram registros que permitiam rememorar a dura experiência da viagem transatlântica; pelo contrário, seu conteúdo trazia informações declaradas em momentos que a morte lhes parecia iminente, e por isso, naquele momento, a experiência do tráfico compreendia apenas uma das diversas realidades pelas quais essas pessoas já haviam vivenciado.

Determinar o tempo entre a travessia do Oceano Atlântico e o registro de um testamento é simplesmente impraticável. Talvez em virtude disso traços muito pequenos fossem esboçados, como fez a preta forra Ângela de Souza Ferreira, moradora em Passagem, que declarou ser "natural da Costa da Mina de onde me trouxeram debaixo [do pejo] do cativeiro ainda em tenra idade"104. Essa declaração demonstra que a experiência havia sido muito remota. A preta forra Francisca da Conceição, moradora em Bento Rodrigues, declarou ter ido para as minas “ainda pagã”,105 e Antônia de Azevedo preta forra informou ter sido batizada na "freguesia da Caxoeira da cidade de Salvador, Bahia, de todos os santos” e não saber quem eram seus pais, “por serem da mesma terra, e vir dela de tenra idade”106.

Ter pouca idade certamente não contribuiria para que o africano apagasse da sua memória a imagem da viagem transatlântica; outros fatores certamente já haviam marcado a vida dessas pessoas. Prova disso foi a declaração de Natária Ribeira Ferreira, moradora em Catas Altas, que informou em seu testamento que já se encontrava no estado de liberta havia

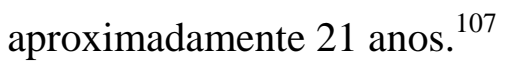

\footnotetext{
${ }^{102}$ Esses valores são apenas aproximações. Nas ações de cobrança aparecem cerca de 28 africanos e 18 nascidos na colônia, nas ações de liberdade 40 nascidos na colônia e 20 africanos. De maneira geral, não houve disparidades entre os envolvidos do sexo masculino e feminino.

${ }^{103}$ KLEIN, “A demografia do tráfico atlântico”, p. 135.

${ }^{104}$ ACSM, Inventário, Códice 101, Auto 2105.

${ }^{105}$ ACSM, Testamento, Livro 57.

${ }^{106}$ ACSM, Inventário, Códice 56, Auto 1231.

${ }^{107}$ ACSM, Inventário, Códice 88, Auto 1907.
} 
Essas pequenas trajetórias de vida declaradas, fossem de africanos ou não, buscavam sempre reforçar a legitimidade da liberdade alcançada. Muitas alforrias se deram a partir da quitação de "seu valor” e era importante esclarecer ainda a autenticidade desse documento, como enunciaram vários libertos, dentre eles, Tereza Gomes de Abreu, moradora em Bento Rodrigues, que, no momento daquele registro, “pela mercê de Deus” se encontrava "forra e liberta como melhor constar da minha carta de liberdade, que se acha em um dos cartórios da cidade de Mariana”. 108 Ou ainda, Tereza de Jesus, preta forra, "natural da Costa da Mina de nação cravari”, que se encontrava "forra e liberta” por carta de liberdade a ela passada, "lançada no livro de notas, em um dos cartórios da cidade de Mariana, dos tabeliães da mesma cidade”. ${ }^{109}$

No tocante às múltiplas experiências pelas quais passaram esses libertos, sem dúvida alguma a transição da escravidão para a liberdade foi a mais importante, e é exatamente essa ruptura que une povos de regiões e culturas tão diferenciadas. Se traços comuns relacionados às suas origens funcionaram como mecanismos de aproximação entre os mesmos na colônia, é necessário lembrar que antes disso viveram numa sociedade moldada pelo sistema escravista, demarcada pela cisão entre senhores e escravos. Contudo, uma comunidade também marcada pela presença de redes de solidariedade traçadas a partir de relações pessoais verticais e horizontais, que permitiu com que alguns alcançassem posições mais privilegiadas que outros.

As relações estabelecidas por esses grupos egressos do cativeiro certamente ultrapassavam os limites da progênie, da nacionalidade, ou das identidades étnicas criadas sob o regime escravista. Ainda que fossem unidos por um passado em cativeiro, protagonizaram diferentes trajetórias sociais após a emancipação.

\footnotetext{
${ }^{108}$ ACSM, Inventário, Códice 135, Auto 2731.

${ }^{109}$ ACSM, Testamento, Livro 47.
} 


\section{CAPÍTULO 2}

\section{Sobrevivendo forro: indícios de pobreza e de propriedade.}

A população liberta de Mariana no ano de 1742 não ultrapassou a soma de 260 pessoas. ${ }^{1}$ Mesmo considerando a possibilidade de aumento na segunda metade do século XVIII, os estudos dedicados à alforria nos mostraram que suas taxas ainda foram reduzidas se comparadas ao número de escravos na sociedade colonial mineira. Mas, se pensarmos em seu efeito cumulativo ao longo de décadas, percebemos que foram bem representativos para a região da pesquisa em questão. ${ }^{2}$ Mesmo que a maior parte das intenções de alforrias fosse legitimada, há indícios de entraves no decorrer do processo de libertação ou no que diz respeito à manutenção da condição alcançada.

Adquirir o status de liberto significava mudanças profundas. A possibilidade de “dispor de si” implicava direitos e deveres adquiridos, mas, sobretudo, autonomia, sendo a busca pela sobrevivência uma de sua mais importante faceta. Ainda que as perspectivas de melhores condições de vida fossem limitadas, esse fator não impediu que o sonho de liberdade fosse esquecido ou menosprezado pelos escravos. Assim, a investigação das estratégias de vida adotadas por esses sujeitos após a obtenção da alforria é de fundamental importância para a compreensão do seu papel na sociedade colonial mineira.

\subsection{O liberto na sociedade colonial}

Alguns escravos gozavam de certa autonomia, mas suas conquistas não se equiparavam às de um liberto. Os ganhos alcançados geralmente guardavam relações com uma modalidade específica de trabalho ou eram simples permissões ajustadas com o proprietário. Mas, de qualquer forma, uma atitude de favorecimento denotaria possibilidade de alteração de uma condição jurídica, ou do alargamento dos caminhos que conduziam a ela.

\footnotetext{
${ }^{1}$ Cf. CARRARA, Ângelo Alves. Agricultura e pecuária na Capitania de Minas Gerais, (1674-1807). Doutorado em História, UFRJ, 1997, p.65.

${ }^{2}$ Stuart Schwartz mencionou a evidência do número de negros a partir do aumento da população colonial rural da América Portuguesa, que possivelmente se deu em função do efeito cumulativo das manumissões e do conseqüente crescimento natural de seus descendentes. SCHWARTZ, Stuart B. Escravos, roceiros e rebeldes. Tradução de José Simões. Bauru: EDUSC, 2001, p.133.
} 
A legitimação dessa conquista, entretanto, se daria somente a partir da obtenção da liberdade, fosse ela comprada ou não. ${ }^{3}$

A mudança de status trazia capacidade civil ao liberto. Assim como para a maior parte da população livre da América Portuguesa, os direitos no plano político eram limitados, já que se tratava de um universo de Antigo Regime; a alteração desse quadro somente viria a ocorrer a partir do início do século XIX. ${ }^{4}$ Nas palavras de Kátia Mattoso, o liberto é “como um menor totalmente emancipado do pátrio poder. Pode até ser escolhido como curador ou tutor de pessoas civilmente incapazes. Mas uma série de restrições privam-no do pleno gozo dos seus direitos políticos”. ${ }^{5}$ As mudanças mais significativas para um escravo que alcançava a liberdade se deram a partir da autonomia adquirida com os direitos de propriedade, herança, família e mobilidade. O que nos parece mais relevante nessas concessões foi o direito à mobilidade espacial, pois, estando em posse da carta de alforria, competia apenas ao liberto a decisão de permanecer ou não próximo do lugar de onde vivera em cativeiro.

Para Kátia Mattoso, a mobilidade trouxe maior autonomia aos ex-escravos, por acreditarem que os vínculos com a servidão somente seriam cortados a partir do afastamento da região de servidão. ${ }^{6}$ Hebe Mattos concorda com a avaliação, considerando que a liberdade motivava a movimentação, que, por sua vez, promovia a reinserção dessa população em outros contextos de relações sociais. Não obstante, Mattos considerou ainda restrita a capacidade de afastamento de um liberto das proximidades de seu antigo senhor, uma vez que aumentaria a possibilidade de reescravização por falta de reconhecimento de sua verdadeira condição. Em suas palavras, “durante a maior parte do período colonial, (...), a mais elementar

\footnotetext{
${ }^{3}$ FLORENTINO, Manolo. "Sobre minas, crioulos e a liberdade costumeira no Rio de Janeiro, 1789-1871". In: FLORENTINO, Manolo (org.) Tráfico, cativeiro e liberdade. Rio de Janeiro, séculos VVII-XIX. Rio de Janeiro: Civilização Brasileira, p.338-341.

${ }^{4}$ Os libertos somente adquiriram direitos civis, mesmo que restritos, a partir da promulgação da Constituição de 1824, quando foram considerados cidadãos brasileiros todos os ex-escravos nascidos no país. A esse liberto caberia o direito ao voto nas eleições primárias desde que comprovasse uma renda anual de 100 mil réis "em espécie, em bens de raiz ou proveniente do trabalho de um cargo", também poderia servir "ao exército, à marinha ou à guarda nacional”, desde que fosse como soldado. MATTOSO, Kátia de Queiroz. Ser escravo no Brasil. $3^{a}$ Edição, São Paulo: Brasiliense, 1990, p. 201-202. Ainda assim, houve a exclusão dos africanos no corpo social da nação, uma vez que foram considerados "cidadãos brasileiros”, e, portanto, passíveis a direitos civis, como o de voto, apenas os libertos nascidos no Brasil. BERBEL, Márcia Regina; MARQUESE, Rafael de Bivar. A escravidão nas experiências constitucionais ibéricas, 1810-1824. Artigo originalmente apresentado ao Seminário Internacional "Brasil: de um Império a Outro (1750-1850)”, organizado pelo Projeto Temático Fapesp "A fundação do Estado e da Nação: Brasil c.1780-1850" no Departamento de História da FFLCH/USP em setembro de 2005, p.32. Cf. BERBEL, Márcia Regina; MARQUESE, Rafael de Bivar. A ausência da raça: cidadania e ideologia pró-escravista nas Cortes de Lisboa e na Assembléia Constituinte do Rio de Janeito (1821-1824). Artigo originalmente apresentado à Conferência "Slavery, Engightenment, and Revolution in Colonial Brazil and Spanish América”, organizado pela Fordham University, New York, 2006.

${ }^{5}$ MATTOSO, Ser escravo no Brasil, p. 201.

${ }^{6}$ MATTOSO, Ser escravo no Brasil, p. 204. Em nosso estudo aventamos essa possibilidade, uma vez que foram raríssimas as constatações de cruzamento das fontes documentais, podendo indicar o afastamento dos libertos da região de Mariana.
} 
decorrência da liberdade - a capacidade de mover-se - esteve violentamente restringida a grande parte dos libertos e de seus descendentes". 7

O caso de Francisco demonstra o peso dessa restrição na trajetória de vida de um egresso do cativeiro. Ele era morador em Mariana e teve sua liberdade ameaçada aos 17 anos de idade. Não possuía carta de alforria, mas, na cidade, todos pareciam reconhecer que era liberto de pia batismal, filho natural de José Manso, português, e de sua escrava Maria Mansa. Depois de libertado, Francisco viveu sob a guarda de seu pai, que logo tratou de sua educação, ordenando que lhe ensinassem a ler e escrever. Em uma viagem a Portugal, na qual o filho o acompanhava, José Manso acabou falecendo, e logo Francisco foi privado de sua liberdade e tratado com injúria em regime de escravidão. ${ }^{8}$

Essa experiência certamente gerou transtornos a Francisco em Portugal; no entanto, desconhecemos tais informações. É certo que, logo que retornou à colônia portuguesa, dirigiuse para as Minas com o intuito de procurar a justiça da cidade de Mariana para tentar comprovar sua verdadeira condição social. Isso não foi difícil, pois, além de apresentar o assento de batismo, algumas pessoas também testemunharam a seu favor, afirmando que tinha sido alforriado pelos seus padrinhos Francisco Martins da Silva e Maria Gomes preta forra, em 31 de janeiro de $1742 .{ }^{9}$ Diante disso, não teve problemas em comprovar sua liberdade, que foi reconhecida pela justiça em 04 de maio de 1759.

Esse liberto cresceu e passou muitos anos de sua vida sem que precisasse de uma carta de alforria para comprovar seu status social. Mas, a partir do momento que se afastou de sua região de origem e perdeu a proteção de seu antigo senhor e pai, foi ameaçado a viver sob um regime que jamais havia conhecido, a escravidão.

O reconhecimento da condição poderia ser mais evidente em algumas situações como a de Francisco, mas havia exceções. Em alguns casos, o simples fato de um liberto

\footnotetext{
${ }^{7}$ CASTRO, Hebe Maria Matos de. Das cores do silêncio: Os significados da liberdade no sudeste escravista. Rio de Janeiro: Nova Fronteira, 1998, p. 35. Sobre o risco de reescravização ver também CUNHA, Manuela Carneiro da. Negros, estrangeiros: os escravos libertos e sua volta à África, São Paulo: Brasiliense, 1985, p. 57.

${ }^{8}$ Por falta de informações no processo, não sabemos como se deu a viagem de Francisco de volta a Mariana; em sua apelação à justiça, restringiu-se apenas à preocupação de comprovar sua condição de liberto a partir de documentos e declarações de pessoas conheciam sua verdadeira condição social na cidade. Ação Cível, Códice 250, Auto 6203, $2^{\circ}$ Ofício, 1759, Arquivo da Casa Setecentista de Mariana. Sílvia Lara também abordou casos de pessoas que tiveram que recorrer a testemunhas para provar na justiça o verdadeiro status de libertos. Para essa autora, fatores como a cor da pele, a ruptura de laços herdados na escravidão contribuíram de maneira marcante para fatos como esses. LARA, Sílvia Hunold. Fragmentos setecentistas: escravidão, cultura e poder na América Portuguesa. Campinas: Instituto de Filosofia e Ciências Humanas/Unicamp, Tese de Livre-Docência, 2004, p. 158-161.

${ }^{9}$ Apesar de reconhecida a paternidade de José Manso, a liberdade do seu filho Francisco pardo não foi concedida gratuitamente. Os depoimentos de João Ferreira dos Santos e José de Barros confirmaram a declaração do Justificante feita no segundo item da justificação, referente ao pagamento de "uma quarta de ouro de mil e quinhentos, que a dinheiro importa em quarenta e oito mil réis", efetuados pelos padrinhos em troca da liberdade.
} 
circular pelas cidades poderia lhe trazer problemas, caso fosse confundido com algum escravo e não estivesse em posse do documento de alforria. Até mesmo diante da morte, poderia haver dúvidas quanto à condição social de uma pessoa, como percebemos nos registros de pessoas falecidas em Mariana na segunda metade do século XVIII, como Domingos preto, "que dizem era forro e pertencia a herança do defunto o Reverendo Manoel Francisco Pereira, e quem o mandou sepultar foi o Testamenteiro do dito, João da Costa Azevedo”. ${ }^{10}$ O mesmo ocorreu com outros indivíduos: Felis Dias, que faleceu "em casa de João da Costa Soares em Santana (...) dizem é forro", ${ }^{11}$ Thereza Alves, que "faleceu sem saber como (...) dizem forra”, ${ }^{12}$ ou o caso intrigante de Tomé, cujo registro anotava ser "escravo de Joana de Figueiredo, que diz ser forro" ${ }^{13}$ Isso nos mostra que, se para alguns houve reconhecimento, para outros sempre houve dúvidas quanto à verdadeira condição social de pessoas de cor.

Mas a liberdade seguida de mobilidade também poderia indicar problemas relativos à sobrevivência, por se tratar de um sujeito sem precedentes, tentando se inserir em uma população de diferente região. Enquanto escravo, permanecia sob a dependência do seu senhor, cuja relação era pautada em constantes obrigações e execuções de tarefas impostas, vivendo, contudo, sob alguma proteção. ${ }^{14}$ Mas, a partir do momento que se tornasse livre, poderia responder por si, teria que se manter e se adaptar às regras vigentes e impostas à sua nova condição social.

José era escravo do defunto João da Costa Santiago, que o deixou coartado em testamento pelo valor de 200 mil réis, para satisfazer no período de quatro anos. ${ }^{15}$ Após dois anos e quatro meses, João ainda não havia cumprido nenhuma parcela da coartação. Esse valor pertencia à herança dos dois filhos menores do falecido, que tinham como tutor Miguel Peixoto de Araújo. Depois de várias tentativas de cobrança, Miguel recorreu à justiça para tentar resolver aquela situação que era prejudicial aos seus tutelados.

Os principais argumentos que sustentaram essa demanda foram baseados em afirmações de que o coartado não poderia ser forro por não ter condições de se sustentar, ainda que se ocupasse do serviço de minerar. Essas limitações se davam "por serem as faisqueiras limitadas e muito diminutas há anos” e assim não realizava suas atividades, mas sim fazia "distúrbios e bulhas com outros negros onde quer que se acha por ir às causas de minerar”. As testemunhas que falaram à justiça em favor do autor do processo afirmaram que

\footnotetext{
${ }^{10}$ AEAM, Registro de óbito, Livro: Q-15, Data do óbito: 13/05/1760, p. 5.

${ }^{11}$ AEAM, Registro de óbito, Livro: Q-18, Data do óbito: 14/04/1788, p. 4.

12 AEAM, Registro de óbito, Livro: Q-17, Data do óbito: 29/06/1784, p. 86.

${ }^{13}$ AEAM, Registro de óbito, Livro: Q-17, p. 85v.

${ }^{14}$ MATTOSO, Ser escravo no Brasil, p.206.

${ }^{15}$ ACSM, Ação Cível, Códice 335, Auto 7969, 1766.
} 
o coartado José apregoava não querer ser forro, mas sim “escravo de um bom branco que lhe desse um bom cativeiro”. A defesa do réu não desmentiu as acusações feitas pelo autor e suas testemunhas, mas tentou argumentar sobre a cobrança feita ainda no prazo de vigência da coartação. Seus argumentos foram em vão, pois a justiça considerou João cativo e ainda o condenou a pagar as custas despendidas com a ação.

Não sabemos se as declarações supostamente feitas pelo coartado eram verdadeiras, nem mesmo contamos com informações deixadas por sujeitos dessa categoria social que indicassem a preferência por “um bom cativeiro” ao invés de desfrutar a própria liberdade. Júnia Furtado abordou o caso de Joana Batista da Capitania do Pará, nascida da relação de um escravo e uma índia, portanto, de ventre livre, que em 1780 renunciou à sua liberdade em troca de “uma velhice amparada, segura e honrada”. Segundo a autora, essa cafusa se vendeu por meio de um instrumento público que assegurava a isenção do cativeiro à sua prole, caso algum dia a tivesse. Sua intenção era de eximir-se da "insegurança diária de uma sobrevivência sem garantias” conferida a partir da aquisição da liberdade. ${ }^{16}$

De fato, esse coartado e essa cafusa podem ter preferido viver em cativeiro com a proteção de seus senhores, ao invés de se aventurarem em busca de angariar recursos para prover o próprio sustento. Mas esse tipo de relato, conforme mencionado, não é comum entre as informações que dispomos sobre os libertos. Essas pessoas quase não deixaram registros que indicassem mais detalhadamente essa experiência. Ainda assim, quando dispomos de alguma observação, estão relacionadas a situações de tensão, como as demandas judiciais; os documentos mais pessoais, como testamentos, não elucidam essa questão. Encontramos apenas um inventário de um liberto, que apesar de apresentar boas condições de vida, possuía distúrbios mentais que traziam à sua lembrança a realidade controversa do cativeiro.

Lourenço Fernandes, preto forro, morador na freguesia do Sumidouro, era considerado como demente na ocasião do seu falecimento, em fins do ano de 1788. Alguns moradores dessa freguesia afirmavam que ele apresentava a dita enfermidade havia mais de 4 anos, o que contribuía para a impossibilitade de administrar os bens que possuía, dentre eles, a sua própria casa, freqüentemente sujeita a furtos. Entre gritos e choros, seus desvarios faziam com que saísse da sua moradia com o intuito de "fugir” dos "Capitães do Mato”, de modo a evitar que o prendessem, lançassem a ferros e depois o matassem. Uma de suas crises foi tão séria ponto de provocar um corte no pescoço “que levou três a quatro pontos”. ${ }^{17}$

\footnotetext{
${ }^{16}$ FURTADO, Júnia Ferreira. Chica da Silva e o contratador de diamantes. O outro lado do mito. São Paulo: Companhia das Letras, 2003, p. 111-112.

${ }^{17}$ ACSM, Inventário, Códice 33, Auto 784.
} 
A condição de liberto não apagava o estigma da escravidão. Isso não significa que fosse impossível o acesso a melhores condições de vida, pois percebemos que suas trajetórias seguiram caminhos diferenciados. Mesmo se caracterizando por situações menos freqüentes que as de dificuldades, não raro esses indivíduos conseguiram ascender economicamente e até mesmo socialmente.

Um dos fatores que contribuiu para a melhoria de vida de um emancipado foi o direito à mobilidade, que potencializou o acesso à família e à propriedade. ${ }^{18}$ Basicamente duas perspectivas marcaram o acesso à família, uma, de natureza afetiva, que se refere à idéia de amparo por laços familiares, e outra, de ordem econômica, ligada à concepção de que o trabalho em conjunto favorecia o acúmulo de pecúlio. Maria Inês Côrtes de Oliveira afirmou que “a motivação básica para o casamento não era a legalização da prole, e sim o auxílio mútuo”. ${ }^{19}$ Segundo Ida Lewcowicz, os casamentos, em Mariana, também se apresentaram como forma de contribuir para o aumento das posses dos cônjuges. ${ }^{20}$ No entanto, parece mais ajustado afirmar que essas uniões não se definiram por esses tipos de tendências, mas sim por questões mais particulares, e, por vezes, imperceptíveis à nossa compreensão. Os libertos testadores de Mariana apresentaram deliberações variadas no que diz respeito à escolha de seus cônjuges e à destinação de suas posses. No caso das partilhas, essas não necessariamente tenderam a se concentrar nas mãos de seus respectivos cônjuges.

Adquirindo a liberdade, essas pessoas tinham que se enquadrar conforme as circunstâncias vigentes na sociedade escravista, exercendo funções que pudessem garantir sua sobrevivência. Núbia Braga Ribeiro resumiu bem as ocupações assumidas por esses indivíduos:

Os forros serviram às milícias, desbravaram sertões, lutaram contra o gentio, na função de capitão-do-mato perseguiram os quilombolas, contribuíram com os reais donativos, foram pequenos roceiros, lavradores, agregados. Donos de escravos, proprietários de pequenos comércios,

\footnotetext{
${ }^{18}$ Para Le Goff, as estruturas institucionais criadas pelas autoridades e a família atuaram como mecanismo de integração de um sujeito de modo a previnir sua inserção na marginalidade. LE GOFF, Jacques. A História Nova. São Paulo: Martins Fontes, 1995, p. 279. Sheila de Castro Faria observou em seu trabalho sobre Campos dos Goitacazes uma predominância de libertos entre a população que migrava e constituía família como forma de adquirir melhores condições de vida. FARIA, Sheila de Castro. A colônia em movimento: fortuna e família no cotidiano colonial. Rio de Janeiro: Nova Fronteira, 1998. p.120.

${ }^{19}$ OLIVEIRA, Maria Inês Côrtes de. O liberto: o seu mundo e os outros, Salvador, 1790-1890. São Paulo: Corrupio, 1988, p.61.

${ }^{20}$ LEWCOWICZ, Ida. "Herança e relações familiares: os pretos forros nas Minas Gerais do século XVIII". Revista Brasileira de História. V. 9, nº17, set.88/fev.89, p. 101-114.
} 
sapateiros, ferreiros, carpinteiros, alfaiates, artesãos, e tantos outros ofícios em busca de sobrevivência. ${ }^{21}$

Assim como os escravos, os libertos também puderam desfrutar de melhores oportunidades de trabalho no meio urbano desenvolvendo atividades favoráveis às necessidades das cidades, como aquelas relacionadas aos ofícios mecânicos e principalmente à produção de bens de consumo. Alguns tocaram seu próprio negócio, como no caso daqueles que se tornaram pequenos comerciantes. Sozinhos ou com seus familiares, puderam adquirir meios de sobreviver, ou mesmo alcançaram melhores condições de vida.

\subsection{O momento da morte}

Acompanhar a trajetória social de uma pessoa é uma tarefa muito difícil, principalmente no que se refere a uma época em que poucos deixavam registros, como o período colonial. Em se tratando da população liberta, essa restrição ainda é maior, pois os documentos mais trabalhados pela historiografia como os testamentos e inventários postmortem, caracterizam apenas uma pequena parcela dessa população em uma situação muito específica.

A história de vida de uma pessoa é composta por diferentes fases. Conforme afirmou Hebe Mattos, “um mesmo indivíduo podia ser duas coisas, em épocas diferentes de sua história de vida”. ${ }^{22}$ Os momentos capturados pela documentação não se estendem ao longo de uma existência. Analisar o momento da morte a partir dos assentos de óbitos pode nos esclarecer características que não estiveram presentes em toda a trajetória do liberto, indicando, contudo, características que outros repertórios documentais não puderam registrar.

Com base nos registros de óbitos do Arquivo Eclesiástico da Arquidiocese de Mariana, examinamos os assentos dos libertos que faleceram entre os anos de 1751 a $1800^{23}$, com o objetivo de conhecer elementos das condições de vida que apresentavam no momento da morte, como os de pobreza. Ao levantar os óbitos de escravos, percebemos igualmente os indícios de propriedade como a inserção no grupo de proprietários de escravos.

\footnotetext{
${ }^{21}$ RIBEIRO, Núbia Braga. Cotidiano e liberdade: um estudo sobre os alforriados em Minas no século XVIII. Dissertação de Mestrado, FFLCH/USP, São Paulo, 1996, p. 108.

${ }^{22}$ CASTRO, Das cores do silêncio, p. 32.

23 Foram incluídos todos os registros de óbitos das seguintes igrejas: Catedral da Sé, Nossa Senhora do Carmo, São Francisco, Confraria, Santana, Nossa Senhora do Rosário, Nossa Senhora das Mercês e São Gonçalo. Devemos considerar que a maior parte desses registros é procedente da Catedral da Sé, pois a maioria das outras igrejas foi construída em fins do século XVIII.
} 
Essa documentação traz basicamente informações como data do óbito, nome completo de falecido, condição social, os sacramentos recebidos, local de moradia, lugar em que o corpo foi sepultado e nome das pessoas que acompanharam o enterro. O assento também faz referência àquelas pessoas que deixaram testamento, em alguns casos, anexado ao documento.

Em primeiro lugar, torna-se necessário esclarecer que esses registros confirmam as considerações feitas sobre os estudos das alforrias, ao apresentarem um aumento considerável de óbitos de libertos na segunda metade do século XVIII. Os escravos que adquiriram liberdade no período de auge da mineração provavelmente faleceram no período posterior, engrossando os índices dos egressos do cativeiro naquela sociedade, como mostram os dados da tabela abaixo:

\begin{tabular}{|c|c|c|c|c|}
\hline \multicolumn{5}{|c|}{ Tabela 4 - Número de óbitos ocorridos em Mariana, 1751 a 1800.* } \\
\hline$\overline{\text { Data }}$ & $\begin{array}{c}\text { Total de óbitos } \\
\text { da população }\end{array}$ & $\begin{array}{c}\text { Óbitos de } \\
\text { libertos }\end{array}$ & $\begin{array}{c}\text { Óbitos de escravos } \\
\text { de proprietários } \\
\text { libertos } \\
\end{array}$ & $\begin{array}{c}\text { \% de fontes } \\
\text { documentais } \\
\text { analisadas } * *\end{array}$ \\
\hline $1751-1760$ & 987 & 47 & 44 & $9,21 \%$ \\
\hline $1761-1770$ & 1130 & 74 & 17 & $8,05 \%$ \\
\hline $1771-1780$ & 1491 & 181 & 22 & $13,61 \%$ \\
\hline $1781-1790$ & 1711 & 226 & 16 & $14,14 \%$ \\
\hline $1791-1800$ & 1752 & 267 & 30 & $16,95 \%$ \\
\hline
\end{tabular}

A Tabela 4 tem como objetivo destacar os principais registros analisados, que foram os óbitos de libertos, de maneira geral, e os óbitos de escravos que pertenciam a pessoas que apresentavam essa mesma condição social. Conforme podemos observar, o total de atas apresenta ainda os assentos de livres e escravos. Apesar de não terem sido especificados separadamente, podemos afirmar, de acordo com estudos já realizados, que a população escrava era predominante nesse período, ${ }^{24}$ o que torna as informações sobre os libertos, representados na dita tabela, ainda mais significativas.

É possível perceber igualmente que os registros aumentam ao longo dos anos. Outro aspecto de relevo é perceber a alteração dos números em relação às características estruturais

\footnotetext{
${ }^{24}$ BERGAD, Laird W. "Depois do boom: aspectos demográficos e econômicos da escravidão em Mariana, 1750-1800”. Estudos Econômicos, 24(3), Dez.1994, p.497.
} 
vigentes: enquanto o conjunto de forros falecidos aumenta, o de escravos de senhores libertos diminui sensivelmente. ${ }^{25} \mathrm{O}$ quadro apresentado nesse momento é de queda do número de importações de africanos para Minas Gerais, mas, ainda assim, os valores dos cativos permanecem estáveis até as primeiras décadas do século XIX, indicando talvez que esses fatores não favoreceram o acesso dos libertos à propriedade escrava. ${ }^{26}$

Tendo em vista que a população forra dos registros de óbitos geralmente é adulta, percebemos algumas características que marcaram a vida dessas pessoas nesse o momento. Sabemos que as pessoas mais abastadas, que completavam idades mais avançadas ou contraíam doenças, tinham uma preocupação muito grande em redigir seus testamentos. Apenas 10,3\% dos libertos falecidos na segunda metade do século XVIII, em Mariana, deixaram registros desse tipo. Considerando que alguns faleceram repentinamente e, portanto, $a b$ intestados, ainda é possível afirmar que uma parcela mínima possuía bens suficientes a ponto de se preocupar com a destinação dos mesmos na ocorrência da morte.

A feitura desses documentos se dava basicamente em função de sinalizar os últimos desejos no que se referia à distribuição da herança e ao cerimonial fúnebre. Toda a atenção dada ao cumprimento dessas determinações estava relacionada às crenças de salvação da alma, ${ }^{27}$ e, para isso, eram feitas revelações de caráter pessoal, reconhecimento de dívidas, de demandas, concessão de esmolas e, sobretudo, a solicitação de celebração de missas, que por vezes atingiram números bem elevados.

\footnotetext{
${ }^{25}$ Fenômeno semelhante é identificado em Vila Rica, onde o percentual de senhores forros, entre 1743 e 1811 , diminuem de 8,8\% para 3,0\%, ver COSTA, Iraci del Nero da; LUNA, Francisco Vidal. “A presença do elemento forro no conjunto de proprietários de escravos”. Ciência e Cultura, 32: p. 836-841, 1980. Em relação aos óbitos de pobres, Iraci del Nero da Costa revelou que, entre 1724 e 1728, eles respondiam por 3,0\% dos registros, ao passo que, entre 1809 e 1813, eles correspondiam a 25,6\% do total de óbitos da paróquia de Antonio Dias de Vila Rica, ver COSTA, Iraci del Nero da; LUNA, Francisco Vidal. Vila Rica: população (1719-1826). São Paulo: IPE/USP, 1979, p. 230-238.

${ }^{26}$ BERGAD, Laird W. Escravidão e história econômica: demografia de Minas Gerais, 1720-1888. Tradução de Beatriz Sidou. Bauru, São Paulo: Edusc, 2004, p.246-247. ALMEIDA, Carla Maria Carvalho de. Alterações nas unidades produtivas mineiras, Mariana - 1750 a 1850. Dissertação de Mestrado, UFF, 1994, 177-178.

${ }^{27}$ CAMPOS, Adalgisa Arantes. "Considerações sobre a pompa fúnebre na capitania das Minas - o século XVIII”. Revista do Departamento de História, FAFICH/UFMG, n4, 1987, p. 5-24.
} 
É certo que, à medida que a pompa barroca aumentava, o custo também era maior. ${ }^{28}$ O funeral de Mariana da Silva, preta forra, moradora na freguesia do Sumidouro, custou 56 oitavas de ouro, ou seja, $67 \$ 200$ réis. Os valores despendidos foram com ofício de corpo presente, acompanhamento, missas, direitos paroquiais e cera. Essa liberta foi amortalhada em hábito de São Francisco e sepultada dentro da matriz dessa mesma freguesia. ${ }^{29} \mathrm{O}$ funeral de Natária Ribeira Ferreira, moradora em Catas Altas, custou à sua testamentaria o valor de 34 oitavas, $3 / 4$ e 7 vinténs de ouro. ${ }^{30}$ Eram, portanto, valores consideráveis, relativos a praticamente metade do preço de um escravo em boas condições de trabalho, ou ainda de uma residência mais modesta.

Os registros de óbitos dos libertos de Mariana trazem informações muito sucintas, mas que denotam as preocupações desses sujeitos em momentos de aproximação da morte. Os dados mais gerais se referem aos sacramentos ministrados, às missas deixadas e ao acompanhamento do corpo à sepultura. A maior parte dos moribundos recebia os sacramentos de penitência e extrema-unção, alguns ainda confessavam. A ausência desses atos só se dava em casos de falecimento repentino, ou quando derivava de algum tipo de moléstia que os impedia de acontecer.

O número de missas deixadas oscilou entre 4 e 30. Josefa da Matta, preta forra, faleceu do dia 11 de outubro de 1766 e foi enterrada na Igreja do Rosário dos pretos, deixando 12 missas de corpo presente. ${ }^{31}$ Izabel Tereza Telles, preta forra, morreu sem testamento, mas também deixou 30 missas de corpo presente. ${ }^{32}$ João, preto forro, deixou 8 missas de corpo presente e 200 missas de $1 / 2 .{ }^{33}$ Outros deixavam também esmolas, como a preta forra Roza Maria de Carvalho, que faleceu em junho de 1762 e deixou quatro missas de corpo presente e uma oitava de ouro em esmola. ${ }^{34}$

\footnotetext{
${ }^{28}$ Após o falecimento de uma pessoa de posses, era aberto o testamento e posteriormente se dava a feitura do inventário. Uma parcela do montante desses bens era destinada aos gastos com a pompa fúnebre, mas a sua distribuição, segundo Eduardo França Paiva, se dava da seguinte forma: "Primeiramente deveria ser calculado o "Monte Mor" do qual seriam subtraídas as dívidas do casal e abatidos os gastos (provavelmente com alguma doença do falecido, embora não tenham sido especificados), chegando-se, assim, ao "Líquido". Este montante líquido deveria ser dividido em duas partes - "Meação" - sendo uma delas encaminhada integralmente à viúva. A outra metade seria dividida em três partes, sendo uma delas - a Terça - destinada ao cumprimento dos legados previstos em testemunho e as outras duas - "Dois Terços" - destinados aos herdeiros. Caso o pai lhes deixasse (em testamento provavelmente) o "Remanescente" - o que não de despendera da terça -, nova divisão entre os herdeiros deveria ser empreendida.” PAIVA, Eduardo França. "Os inventários mineiros: fontes para a história colonial”. Cadernos de Filosofia e Ciências Humanas, Ano I, Nº1, outubro/93, p.28.

${ }^{29}$ ACSM, Inventário, Códice 122, Auto 2456, 1755.

${ }^{30}$ ACSM, Inventário, Códice 88, Auto 1907.

${ }^{31}$ AEAM, Registro de óbito, Livro: Q-13, p. 60.

${ }^{32}$ AEAM, Registro de óbito, Livro: Q-13, p. 52.

${ }^{33}$ AEAM, Registro de óbito, Livro: Q-13, p. 50.

${ }^{34}$ AEAM, Registro de óbito, Livro: Q-13, Data do óbito: 09/06/1762, p. 53v.
} 
Informações mais detalhadas sobre as missas podem ser apreendidas a partir das

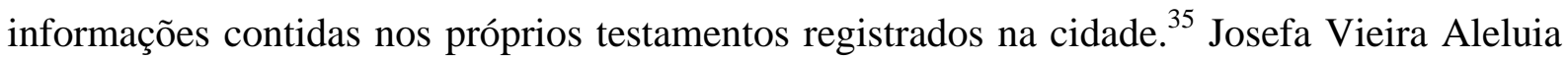
determinou que 70 missas fossem celebradas no "altar privilegiado de Nossa Senhora do Rosário” do arraial da Passagem. A cada uma se daria de esmola meia oitava de ouro, sendo 30 pela própria alma, 20 pela do seu patrono e 20 pelas almas do seu padrinho e madrinha. ${ }^{36}$ Muitos pedidos eram destinados a missas no Rio de Janeiro e até mesmo houve intenções de celebrações para “os religiosos da Terra Santa”. Além desses gastos, havia o desejo de deixarem esmolas a pessoas conhecidas, a afilhados e às irmandades.

Percebemos também nos óbitos grande envolvimento dos libertos com as irmandades. Essas organizações tinham implicações importantes na vida desses sujeitos, como conotações de assistencialismo, amparo material em vida ou diante da morte, além de representar distinção social aos confrades. Na segunda metade do século XVIII, a região urbana de Mariana e suas adjacências já contavam com um número considerável dessas confrarias, dentre elas Nossa Senhora do Rosário dos Pretos, Nossa Senhora de Santana, Nossa Senhora da Glória, Santa Ifigênia, São Benedito, São Miguel e Almas, Nossa Senhora do Monte do Carmo, Nossa Senhora das Mercês, Arquiconfraria dos Pardos, Confraria de São Francisco, Nossa Senhora da Boa Morte, dentre outras.

As irmandades tinham um papel importante na vida dos libertos, bem como dos escravos e mulatos na América Portuguesa. Eram entidades oficialmente reconhecidas, que ora poderiam ser vistas como instrumento de controle e dominação, ora como espaço de autonomia e integração dessa parcela da população. ${ }^{37}$ Seja como for, a inserção nessas associações lhes conferia “coesão e unidade de propósito e agir coletivamente no ambiente social econômico da escravidão”. ${ }^{38}$

Os forros que faleceram eram mais agregados à Irmandade do Rosário dos Pretos. Ainda que os escravos fossem predominantemente mais numerosos entre os confrades ${ }^{39}$, os libertos também tiveram uma grande participação, desempenhando funções e cargos

\footnotetext{
${ }^{35}$ Ao levantamos os nomes dos libertos que deixaram testamentos a partir da indicação dada nos assentos de óbitos, houve a tentativa de localizar esses documentos nos livros cartoriais. No entanto, foi insignificativa a correspondência entre os nomes, o que nos leva a concluir que a feitura dos testamentos por parte dos libertos foi muito maior do que o total de documentos de que dispomos.

${ }^{36}$ ACSM, Inventário, Códice 106, Auto 2183.

${ }^{37}$ LARA, Fragmentos Setecentistas, p.243.

${ }^{38}$ RUSSELL-WOOD, A.J.R. Escravos e libertos no Brasil colonial. Rio de Janeiro: Civilização Brasileira, 2005, p. 165.

${ }^{39}$ Especificamente entre os anos de 1750 a 1819, foram encontrados 581 escravos, sendo 419 homens e 162 mulheres, e 239 libertos, 93 homens e 146 mulheres. PINHEIRO, Fernanda Aparecida Domingos. Confrades do Rosário: sociabilidade e identidade étnica em Mariana - Minas Gerais (1745-1820). Niterói: ICHF/UFF, Dissertação de Mestrado, 2006, p.67.
} 
diferenciados que lhes garantiram grande liderança e prestígio social. Essas ocupações poderiam ser de cunho festivo ou administrativo, sobressaindo-se os de mesários, Reis, Rainhas, ou aqueles destinados a angariar recursos. ${ }^{40}$ Os cargos de escrivão e tesoureiro se tornavam mais restritos devido à alta taxa de analfabetismo entre esses sujeitos. ${ }^{41}$

Ainda que não tivessem redigido testamentos, muitos libertos foram assistidos por irmandades na ocasião da morte. Páscoa Magalhães, preta forra, casada com Vicente Pires, pardo forro, faleceu em 30 de janeiro de 1791, sem sacramentos por morrer “apressadamente”, evidentemente sem testamento; no entanto, “foi envolta em hábito preto, levada à sepultura em caixão, acompanhada pelo seu Reverendo Pároco e pelas Irmandades de Nossa Senhora do Rosário dos Pretos e da Boa Morte e mais alguns sacerdotes”. ${ }^{2}$ Marcela, crioula forra, casada com Domingos Duarte, também crioulo forro, foi sepultada em cova da Irmandade da Boa Morte e seu cortejo fúnebre se deu da seguinte maneira: "foi levada à sepultura em tumba da Irmandade de Nossa Senhora da Boa Morte, acompanhada pela mesma Irmandade e pela do Rosário dos Pretos e pelo seu Reverendo Pároco e dois sacerdotes". ${ }^{43}$

Eram freqüentes os anseios de assistência das irmandades nos rituais fúnebres, geralmente especificados em disposições testamentárias. Francisca da Conceição, preta forra, moradora em Bento Rodrigues, solicitou que seu corpo fosse amortalhado em "hábito de São Francisco, e na falta dele, em um lençol branco de pano de linho”. Depois da celebração de uma missa de corpo presente, deveria prosseguir o cortejo fúnebre, conduzido pelo reverendo pároco daquela capela, mais quatro sacertores, acompanhado pelas Irmandades do Santíssimo Sacramento e das Almas, e ainda carregada em Tumba “do glorioso São Benedito”, onde já havia exercido as funções de Rainha e Juíza. ${ }^{44}$ Quitéria Cardosa, moradora em Mata Cavalos, Mariana, esperava que seu corpo fosse "amortalhado em hábito de São Francisco e levado ao local de sepultamento em Tumba de Nossa Senhora do Rosário”, de que era irmã e havia sido Juíza. O cortejo fúnebre deveria ser acompanhado pelo reverendo cura, 11 sacerdotes e Irmandades de São Benedito, Arquiconfraria e Santa Efigênia. ${ }^{45}$

Além de exigirem o sepultamento na capela da Irmandade à qual pertenciam, não raro os libertos deixavam esmolas e até mesmo parte dos bens que possuíam para as mesmas, caso não houvesse um herdeiro. Luiza de Souza, que morava defronte a Sé, faleceu em 13 de

\footnotetext{
${ }^{40}$ PINHEIRO, Confrades do Rosário, p. 124-126.

${ }^{41}$ RUSSELL-WOOD, Escravos e libertos no Brasil colonial, p. 206.

${ }^{42}$ AEAM, Registro de óbito, Livro: Q-10, p. 29v.

${ }^{43}$ AEAM, Registro de óbito, Livro: Q-10, p. 28v.

${ }^{44}$ ACSM, Testamento, Livro 57.

${ }^{45}$ ACSM, Testamento, Livro 55.
} 
maio de 1782, “deixando as casas em que morava para a Irmandade de Nossa Senhora da Conceição". 46

A garantia de que a divisão de bens do falecido fosse consumada conforme havia determinado era outra característica importante dos testamentos. Se o forro morresse sem redigir esse documento, suas posses automaticamente seriam distribuídas entre os membros da família. Caso não os tivesse, seriam entregues ao Estado, como os de todos os homens livres sem herdeiros. ${ }^{47} \mathrm{O}$ que aconteceu com Maria Lopes Correa, parda forra, demonstra o primeiro caso. Ela faleceu no dia 30 de março de 1773, sem testamento, mas seus haveres acabaram ficando para a sua mãe. ${ }^{48}$ Já os bens de Ignácia Maria do Espírito Santo parecem demonstrar indícios do segundo caso, pois “foram arrecadados pelo Juízo dos Absentes” pelo fato dessa preta mina forra ter sido considerada demente. ${ }^{49}$

A justiça de Mariana interferiu na partilha dos bens de um liberto anteriormente mencionado, o preto Lourenço Fernandes, que somavam 225\$675 réis. Ele era viúvo e não tinha filhos, mas parecia ter instituído uma pessoa como herdeira, segundo informações contidas em seu testamento, supostamente redigido em 8 de março de 1788. Mas a distribuição dos pertences não seguiu suas determinações, pois foi comprovado o estado de demência em que já se encontrava no momento de feitura daquele registro, e o oportunismo de pessoas que o seduziram e induziram a fazer as declarações ali contidas. Em 17 de novembro de 1788, a justiça ordenou que fosse nomeado um curador para cuidar da destinação de suas posses. ${ }^{50}$

Um ponto fundamental para se compreender as relações dos libertos com a sociedade é a identificação das pessoas a quem confiavam a distribuição de seus bens - os testamenteiros. Essa pessoa deveria ser alguém de grande confiança dos testadores, fosse parente ou não, livre, forro, branco ou negro. O testamento era um documento que continha informações muito pessoais e, por vezes, sigilosas. Após o término da sua confecção, alguns procedimentos eram tomados com o intuito de manter as declarações em segredo. Na ocasião da abertura, seria importante que as marcas impressas na selagem estivessem intactas, sem qualquer indício de violação. Em 1782, foi aberto o testamento de Lauriana de Souza preta

\footnotetext{
${ }^{46}$ AEAM, Registro de óbito, Livro: Q-17, p. 51v.

${ }^{47}$ MATTOSO, Ser escravo no Brasil, p. 180.

${ }^{48}$ AEAM, Registro de óbito, Livro: Q-16, p. 27v.

${ }^{49}$ AEAM, Registro de óbito, Livro: Q-14, data do óbito: 28/08/1793, p. 95v.

${ }^{50}$ ACSM, Inventário, Códice 33, Auto 784.
} 
forra, e esse documento se apresentava "cozido com cinco pontos de linha vermelha, e outros tantos pingos de lacre por lado, sem vício algum”. 51

As indicações dos testamenteiros contidas nos registros de óbitos apontam para pessoas de variadas origens. Percebemos testadores que tinham escolhido pessoas da família, como irmãos, cônjuges ou filhos. O preto forro Miguel Fernandes, casado e morador no Rosário Velho, teve como testamenteira a sua esposa. Ele faleceu em 11 de março de 1757 e até efetuarem o seu registro de óbito não haviam lançado seu testamento, por demora na entrega. ${ }^{52}$ Os documentos registrados em cartório geralmente apresentam a indicação de mais de uma pessoa. Isso se dava geralmente pela impossibilidade do exercício dessa função pela primeira pessoa solicitada. Também foram freqüentes os casos de indicações de parentes, com forte predominância de indicação do cônjuge.

Muitos testamenteiros não tinham nenhum vínculo familiar com os testadores, mas, ainda assim, poderiam ser pessoas de mesma origem social, ou simplesmente sujeitos por quem cultivavam sentimentos de respeito e desvelo. Ilena Alves, preta forra, procedente da Costa da Mina, faleceu no dia 04 de abril de 1776 e indicou o preto forro João Carvalho. ${ }^{53}$ Josefa Martins escolheu o preto forro Miguel Pinto. ${ }^{54}$ José de Deus, preto forro, foi o testamenteiro de Domingos Dias Penido ${ }^{55}$, dentre outros. Por razão de não possuir herdeiros, Izabel Fernandes, preta forra, desejava que seu testamenteiro também fosse o sucessor de sua herança e, portanto, “este ou aquele que me for mais grato”. Possuía duas casas de morada em Catas Altas, que haviam sido adquiridas por seu "trabalho, serviço e indústria”. Assim, nomeou José Álvares de Matos, pessoa que considerava “como se fora meu parente e sendo necessário o nomeio e declaro por filho adotivo, tudo em remuneração e satisfação dos muitos benefícios que dele tenho recebido". 56

Eugênia, crioula forra, escolheu para ser seu testamenteiro o preto José Gonçalves da Matta. Não havia a indicação da condição social, o que nos leva a acreditar que era um homem livre, e não liberto. ${ }^{57}$ Por outro lado, a preta forra Tereza de Jesus, moradora em Mariana, parece ter escolhido um homem branco que, além de ser seu testamenteiro, também era seu herdeiro, o morador da Cachoeira Antônio da Costa Lopes. ${ }^{58}$

\footnotetext{
${ }^{51}$ ACSM, Testamento, Livro 57.

52 AEAM, Registro de óbito, Livro: Q-14, p. 95v.

${ }^{53}$ AEAM, Registro de óbito, Livro: Q-11, p. 71.

${ }^{54}$ ACSM, Inventário Códice 106, Auto 2183.

55 ACSM, Testamento, Livro 64.

${ }^{56}$ ACSM, Testamento, Livro 51.

${ }^{57}$ AEAM, Registro de óbito, Livro: Q-11, data do óbito: 21/04/1788, p. 78.

${ }^{58}$ AEAM, Registro de óbito, Livro: Q-13, p. 55.
} 
Independente da condição social, o que parecia mais importante era garantir a execução das disposições conforme estavam especificadas nos registros. A partir do conhecimento das indicações dos testamenteiros, podemos inferir que as relações dos libertos se estabeleciam com pessoas dos mais diferentes estratos sociais. O liberto Miguel Rosalis, “falecido nos arrabaldes” da cidade de Mariana, em 12 de junho de 1769, determinou em 7 de novembro do ano anterior que

nenhum juiz assim eclesiástico, como secular se entrometa na administração paga ou distribuição de missas e mais legados neste meu testamento declarados, porque é minha vontade que tudo seja por mão e disposição de meu testamenteiro. Este só poderá ser obrigado apresentar documentos para ante o Juiz da Conta para final cumprimento de tudo se lhe dar quitação geral. $^{59}$

Nota-se também a indicação de pessoas que exerciam certa influência na sociedade, como párocos, alferes, capitães, e até mesmo antigos senhores. Essas indicações certamente eram fruto de relações pessoais assimétricas que permeavam o cotidiano desses libertos. $\mathrm{O}$ Alferes João Pereira de Faria foi testamenteiro de Justa, preta forra; ${ }^{60}$ outro Alferes e procurador da Arquiconfraria, Vicente de Moraes foi indicado por Marcelina Soares, crioula forra, e viúva; ${ }^{61}$ o Padre Luis Antônio da Costa, por Ana Maria Pinta, preta forra. ${ }^{62}$ Antigos senhores foram testamenteiros dos libertos Antônio Dias Martins, preto, morador no Morro Santana $^{63}$ e do crioulo Diogo de Souza Coelho, morador em Mariana. ${ }^{64}$

Conforme afirmação anterior, apenas 10,3\% dos registros de óbitos de libertos apontam a existência de testamentos. Desses, 54 eram mulheres e 28 homens. Os que indicam o estado civil somam 5 homens e mulheres casadas; 2 viúvos e 2 viúvas; e 1 mulher solteira. Os demais não fizeram referências quanto ao estado civil do falecido. ${ }^{65}$

Nos assentos de óbitos, o número de mortes de mulheres forras é superior ao número de homens. Esses dados também confirmam a predominância de mulheres alforriadas em relação aos homens em Mariana colonial. Dos 795 registros encontrados, 465 são de mulheres, enquanto 330 são de homens. Poucos são os registros de óbitos de libertos que

\footnotetext{
${ }^{59}$ ACSM, Testamento , Livro 55.

${ }^{60}$ AEAM, Registro de óbito, Livro: Q-17, p. 95.

${ }^{61}$ AEAM, Registro de óbito, Livro: Q-10, p. 234.

${ }^{62}$ AEAM, Registro de óbito, Livro: Q-17, p. 23.

${ }^{63}$ ACSM, Inventário, Códice 68, Auto 1493.

${ }^{64}$ ACSM, Inventário, Códice 68, Auto 1493.

65 Trata-se, portanto de indicações referentes aos registros de óbitos, pois os testamentos registrados junto aos assentos somam apenas 12, sendo 6 homens e 6 mulheres.
} 
trazem a indicação do estado civil do falecido; apenas 96 possuem alguma indicação, que são mostrados na Tabela 6:

\begin{tabular}{lccc}
\hline \multicolumn{4}{c}{ Tabela 5. Estado civil dos libertos falecidos em Mariana, 1751-1800 } \\
\hline & Homens & Mulheres & Total \\
\hline Casado & 33 & 43 & 76 \\
\hline Viúvos & 5 & 7 & 12 \\
\hline Solteiros & 1 & 7 & 699 \\
\hline $\begin{array}{l}\text { Outros (sem } \\
\text { indicação) }\end{array}$ & 291 & 408 & \\
\hline $\begin{array}{l}\text { Fonte: Registros de óbitos - Arquivo Eclesiástico da Arquidiocese de Mariana - Livros: Q-10, Q-11, } \\
\text { Q-13, Q-14, Q-15, Q-16, Q-17 e Q-18. }\end{array}$
\end{tabular}

Em relação ao total de registros encontrados, esses números representam, para os forros casados, 9,6\%, viúvos, 1,5\%, e os solteiros, $1,0 \%$ do total de falecidos. Sobre os casados, foi possível levantar algumas informações, como no caso de Esperança Soares Pinta, preta forra, que morreu em fevereiro de 1784 e era casada com José Pinto, também preto forro. Seu sepultamento se deu na matriz da cidade e "foi amortalhada em hábito de São Francisco, acompanhada pelas irmandades das Almas e do Rosário dos Pretos e pelo Reverendo Pároco, que a encomendou e sepultou”. ${ }^{66}$ Em seu registro de óbito, há indicação de ter falecido com o seu "solene testamento", que poderia ser um indício de boa condição de vida material ou de posse de bens imóveis e de escravos, muito embora isso não seja uma regra em relação a todas as pessoas que deixaram testamentos, pois os inventários postmortem, com certa freqüência, continham apenas objetos de uso cotidiano ou de trabalho.

No caso de José Jorge da Cruz, pardo forro, casado com Esperança de Brito, falecido em 13 de maio de 1781, também existe referência de ter deixado seu "solene testamento". Além disso, consta a sua ocupação, que era oficial de ferreiro, informação muito rara nesse tipo de registro e que também pode indicar uma distinção em relação aos outros forros. ${ }^{67}$ Alguns registros apontaram ocupações como as de ferreiro, carniceiro, alfaiate carapina, barbeiro e até tesoureiro mor, que foi uma das profissões de Domingos, crioulo forro, falecido em 29 de abril de $1771 .^{68}$

A união de bens por meio do casamento pode ter sido uma expectativa frustada entre os libertos. Quando Ângela de Souza Ferreira se casou com João Monteiro crioulo forro, já

\footnotetext{
${ }^{66}$ AEAM, Registro de óbito, Livro: Q-10, p. 202v.

${ }^{67}$ AEAM, Registro de óbito, Livro: Q-17, p. 44.

${ }^{68}$ AEAM, Registro de óbito, Livro: Q-16, p. 142.
} 
estava com mais de sessenta anos, por isso não tiveram filhos legítimos e nem mesmo naturais. Esse matrimônio durou mais de dez anos, mas, ainda assim, Ângela nomeou como sua “universal herdeira nas duas partes” dos seus bens a crioulinha Francisca, filha de uma escrava chamada Juliana. Essa liberta demostrava certa insatisfação com o marido, ao declarar que "ficando sempre em minha casa e eu tratando dele e sustentando por rigorosa obrigação de casada, sem que o mesmo cooperasse para os teres e haveres de sua rigorosa obrigação de casado". 69

Embora os matrimônios tenham sido identificados pela historiografia como um artifício de se constituir uma vida melhor através da união de bens e da legalização da prole, ${ }^{70}$ percebemos que algumas condições especificadas nos testamentos não sustentam essas generalizações. Em primeiro lugar, é importante considerar que em alguns casos os casamentos dos libertos eram tardios, e, sendo assim, não geravam prole. Algumas libertas se casavam com idades bem avançadas, portanto, desprovidas de capacidade produtiva. Joana de Carvalho da Silva moradora em Mariana, que se casou em "face da Igreja na forma do Sagrado Concílio Tridentino com o senhor João Carvalho da Silva, preto forro”, ainda não havia completado 50 anos naquela ocasião, mas possuía 3 filhos tidos antes dessa união. ${ }^{71}$

Outro fator era a destinação dos bens. Alguns libertos deixavam bem definidas as intenções de que seus cônjuges não fossem herdeiros de seus cabedais. Mariana da Silva preta forra era viúva e se casou pela segunda vez com Luciano dos Santos carijó. Declarou em seu testamento que a maior parte dos bens que possuía havia sido adquirida depois do falecimento do seu primeiro marido, e os poucos granjeados depois, foram por "sua agência”, pois seu esposo era "filho do gentio da terra, incapaz por natureza de adquirir coisa alguma". ${ }^{72}$

Joana Paes Pena foi ainda mais enfática quanto à distribuição dos bens, declarando que

(...) hoje me acho solteira, mas no caso que ao futuro, ou ao tempo do meu falecimento eu estiver tomado estado de casada, mando e ordeno a meus testamenteiros que de tudo (...) o dito meu marido sairá com aqueles bens com que ele entrar para o casal, porque não é minha vontade que ele tenha meação do que é meu, e quando ele morra primeiro, também eu não quero entrar a bens que ele possa trazer; mas sim, cada um de nós sairá com

\footnotetext{
${ }^{69}$ ACSM, Inventário, Códice 101, Auto 2105, 1799.

${ }^{70}$ LEWCOWICZ, Ida. Vida em família: caminhos da igualdade em Minas Gerais (séculos XVIII e XIX). São Paulo, Tese de Doutorado, FFLCH/USP, 1992, p.108. OLIVEIRA, O liberto, p. 61.

${ }^{71}$ ACSM, Inventário, Códice 80, Auto 1693.

${ }^{72}$ ACSM, Inventário, Códice 122, Auto 2456.
} 
aquilo que era seu por assim o contratarmos, ou antes do nosso ajuntamento (...) cada um sairá com aquilo com que entrou. ${ }^{73}$

O esforço em função de adquirir posses talvez fosse um dos motivos que levaram libertos a demarcá-los e fazer conjecturas quanto às suas origens. O marido de Tereza Maria de Jesus vivia ausente e não a provia de nenhuma ajuda financeira, fator que a levou a declarar que ambas as casas que possuía tinham sido adquiridas apenas por sua "agência”, sem que o esposo concorresse em tempo algum para pagamento das mesmas. ${ }^{74}$ Josefa Vieira Aleluia também foi muito incisiva quando declarou que os bens que possuía foram adquiridos por sua “agência e indústria, e não herdados”. 75

Conforme vimos com a liberta e seu marido carijó, a condição social do cônjuge também pode ter influenciado na partilha do pecúlio. Por ser casada com um escravo, Rita de Freitas enunciou que não lhe tocava nada de seus bens, pois esses haviam sido adquiridos “por seu trabalho e indústria. O marido só teria direito à meação, caso estivesse liberto na ocasião da sua morte. ${ }^{76}$ João Pereira da Cunha, preto forro, morador em Bento Rodrigues, se casou com uma escrava e depois dessa união, passou uma carta de alforria à mesma com a condição de que não herdaria nada da sua "fazenda" ${ }^{77}$

A junção de bens não necessariamente funcionou como vetor para os casamentos dos libertos, mas isso não implica que esse elemento estivesse excluído de algumas das uniões, sobretudo aquelas em que foram instituídos como herdeiros os cônjuges. O marido de Luiza Ferreira Vale foi seu herdeiro e testamenteiro. ${ }^{78}$ Também foram herdeiros os maridos de Tereza Gomes de Abreu ${ }^{79}$ e Josefa Rodrigues da Silva ${ }^{80}$. No entanto, os maiores herdeiros eram, sem dúvida alguma, os filhos, fossem naturais ou legítimos, seguidos de nomeação da “alma”.

Algumas libertas tiveram filhos sem que houvessem contraído matrimônio. Natária Ribeira, moradora em Catas Altas, teve 5, mas admitiu que foram fruto de sua "miséria e grandes pecados” e pedia misericórdia a Deus por tais atos. ${ }^{81} \mathrm{Na}$ falta de algum parente, ou de outros herdeiros naturais, os libertos desejavam dividir suas posses entre pessoas de seu convívio, principalmente entre afilhados, filhos de conhecidos e de suas escravas. As crianças

\footnotetext{
${ }^{73}$ ACSM, Testamento, Livro 50, 1756.

${ }^{74}$ ACSM, Inventário, Códice 122, Auto 2541, 1790.

${ }^{75}$ ACSM, Inventário, Códice 80, Auto 1690, 1785.

${ }^{76}$ ACSM, Inventário, Códice 124, Auto 2603, 1775.

${ }^{77}$ ACSM, Testamento, Livro 51.

${ }^{78}$ ACSM, Testamento, Códice 55.

${ }^{79}$ ACSM, Inventário, Códice 135, Auto 2731.

${ }^{80}$ ACSM, Testamento, Livro 54.

${ }^{81}$ ACSM, Inventário, Códice 88, Auto 1907, 1751.
} 
cativas eram nascidas e criadas sob seus os olhares, algo que certamente contribuiu para uma relação de afeto que justificava algumas das concessões a elas conferidas, como a alforria e parte dos legados.

Essas características se referem apenas a situações apreendidas a partir de uma leitura mais minuciosa dos registros de óbitos e das disposições testamentárias. No que concerne aos óbitos, especificamente, foi possível identificar algumas situações vivenciadas pelos libertos com relação ao período final de suas vidas. Conforme mencionado anteriormente, observamos indícios de posses a partir da menção da existência de um testamento, ou de propriedade escrava, por meio dos assentos de escravos falecidos que pertenciam a indivíduos dessa categoria social. Também foi possível caracterizar traços de pobreza procedidos de algumas denominações dadas pelos párocos ou responsáveis pela feitura desses registros. Os resultados mais precisos podem ser apreciados na tabela abaixo:

\begin{tabular}{cccccc}
\hline \multicolumn{7}{c}{ Tabela 6 - Óbitos de libertos pobres e registros que não especificavam } \\
nenhuma condição, 1751-1800.
\end{tabular}

Fonte: Registros de óbitos - Arquivo Eclesiástico da Arquidiocese de Mariana - Livros: Q-10, Q-11, Q-13, Q-14, Q-15, Q-16, Q-17 e Q-18.

A Tabela 6 demonstra basicamente as classificações que puderam ser feitas a partir do levantamento dos óbitos dos libertos de Mariana. Foram considerados os forros que não possuíam nenhuma indicação que pudesse esclarecer a situação em que se encontravam no momento da morte, mas também aqueles que foram classificados como pobres. Conforme se apresentam os dados, percebemos que aqueles, cujos assentos não apontavam uma condição, representavam o grupo mais numeroso do universo que estudamos. A princípio, não podemos classificá-los como "pobres". Porém, há casos que podem apresentar indícios de condição de pobreza, como o da preta mina Joana Vieira, falecida em primeiro de maio de 1782, enterrada dentro da Capela de Nossa Senhora dos Pretos, moradora em casa de Lourenço Paio, preto 
forro, residente neste arraial. ${ }^{82}$ Essa forra, provavelmente, vivia como agregada de um preto forro, podendo indicar uma relação boa de convívio e auxílio entre esses indivíduos de mesma condição social, graças ao fato de um possuir melhor condição econômica do que o outro.

Os forros agregados somaram 12 pessoas nos registros de óbitos. Desses, 7 pareciam viver sob a proteção de pessoas de destaque na sociedade, como nos casos a seguir: Quitéria Maria da Silva, preta forra, agregada do Sargento Mor Antônio Alves Pereira, ${ }^{83}$ Jerônima, solteira, parda forra, do Doutor João de Souza Barradas, ${ }^{84}$ Francisca, forra, do Capitão José Ribeiro de Carvalho, ${ }^{85}$ Francisca, preta forra, do Capitão José Pinheiro, ${ }^{86}$ Luis, crioulo forro, do Reverendíssimo Cônego Jacinto Ferreira dos Santos, ${ }^{87}$ Cristóvão, forro, do Tenente Mor Cristóvão de Araújo $^{88}$ e Escolástica, do Doutor Francisco do Couto Godinho. ${ }^{89}$ Alguns registros também indicavam que o falecido era "assistente” ou morava "em casa de” pessoas com quem parecia não ter vínculos familiares. Esse é um claro indício das redes de clientelismo experimentadas pelos libertos em suas trajetórias sociais. Nas palavras de Richard Graham, “um agregado ou morador dependia de outra pessoa, especialmente para ter casa, ou pelo menos um espaço onde viver e, mais importante, um lugar social (...)”.90

Para Manuela Carneiro da Cunha, o grupo social que mais se adaptava à condição de "agregados" era o dos libertos. Conforme já nos referimos, para esses indivíduos, distanciarem-se do seu antigo senhor poderia lhes trazer dificuldades no que se referia à sobrevivência, bem como para comprovar a condição de alforriado. ${ }^{91}$ Se pensarmos nos termos mais estritos da agregação, sabemos que essa situação se deu basicamente em função da incapacidade de determinados sujeitos viverem de maneira autônoma. ${ }^{92}$ Isso pode indicar que, para aqueles que se sujeitavam a essa situação, o status conquistado com a alforria foi mais importante que os ganhos advindos da alteração da condição social. Mesmo que permanecesse sob o olhar e mando de seu antigo senhor, era um sujeito livre para poder se afastar daquela posição, caso lhe parecesse viável.

\footnotetext{
${ }^{82}$ AEAM, Registro de óbito, Livro: Q-10, p. 198.

${ }^{83}$ AEAM, Registro de óbito, Livro: Q-18, p. 99.

${ }^{84}$ AEAM, Registro de óbito, Livro: Q-18, p. 134.

${ }^{85}$ AEAM, Registro de óbito, Livro: Q-18, p. 149.

${ }^{86}$ AEAM, Registro de óbito, Livro: Q-18, p. 176.

${ }^{87}$ AEAM, Registro de óbito, Livro: Q-18, p. 183.

${ }^{88}$ AEAM, Registro de óbito, Livro: Q-17, p. 97.

${ }^{89}$ AEAM, Registro de óbito, Livro: Q-10, p. 183.

90 GRAHAM, Richard. Clientelismo e política no Brasil do século XIX. Tradução de Celina Brandt. Rio de Janeiro: Editora UFRJ, 1997, p. 37.

${ }^{91}$ CUNHA, Negros, estrangeiros, p. 57.

92 BACELLAR, Carlos de Almeida Prado. “Agregados em casa, agregados na roça: uma discussão”. In: SILVA, Maria Beatriz Nizza da. (Org.). Sexualidade, família e religião na colonização do Brasil. Lisboa: Livros Horizonte, 2001.
} 
Alguns dos registros citados anteriormente nos mostram características importantes da vida dos egressos do cativeiro de Mariana, na segunda metade do século XVIII. Uns trazem indícios que nos permitem considerá-los pessoas de vida simples e vivendo numa situação de dependência econômica em relação a terceiros. Outros nos induzem a pensar que conseguiram obter ascensão econômica, por meio de estratégias como o exercício de algum ofício ou desenvolvimento de outras atividades que pudessem lhes proporcionar a adquisição do próprio negócio e, conseqüentemente, a compra de escravos.

\subsection{Os libertos proprietários de escravos.}

A historiografia aponta a posse de escravos como elemento demarcador da estratificação social em determinada população. Para Iraci Del Nero e Vidal Luna, “a estrutura de posse de escravos apresenta elevada correlação com a própria forma como a riqueza se distribuía entre os mineradores". ${ }^{93}$ Mesmo se tratando de uma região onde as atividades agrícolas se desenvolviam em maior escala, conforme já observamos, os investimentos mais lucrativos ainda permaneciam nas atividades mineradoras. Os recursos adquiridos freqüentemente eram convertidos para a compra de escravos.

As particularidades da dinâmica das regiões mineradoras e urbanas puderam contribuir para o favorecimento de uma mobilidade social. Ainda segundo Iraci Del Nero e Vidal Luna, "ao escravo, obtida a liberdade, tornava-se fácil dedicar-se à faiscação; os resultados de seu trabalho, caso contasse com sorte, poderiam proporcionar-lhe os meios para fazer-se, ele próprio, um senhor de escravos". ${ }^{94}$ Uma forma do liberto negar sua antiga condição social, e lutar contra o estigma que carregava, ocorria por meio da compra de escravos. $^{95}$

O fato de um liberto tornar-se proprietário de escravos estaria relacionado à ascensão econômica, mas também a um artifício de adquirir meios para a sua sobrevivência, podendo viver dos lucros dos serviços de seus próprios cativos. Antônio Luiz preto forro, morador na freguesia do Sumidouro, faleceu deixando parcos bens que somavam apenas $167 \$ 800$ réis, dos quais fazia parte a quantia de 4 oitavas de ouro procedentes dos jornais de um escravo que trabalhou "na lavra de Manoel Antônio”. Ao que tudo indica, tratava-se de

\footnotetext{
${ }^{93}$ LUNA; COSTA, “A presença do elemento forro”, p. 836.

${ }^{94}$ LUNA; COSTA, “A presença do elemento forro”, p. 837.

95 PAIVA, Eduardo França. Escravos e libertos nas Minas Gerais do século XVIII; estratégias de resistência através de testamentos. São Paulo: Annablume, 1995, p. 100.
} 
Pedro benguela, de sessenta anos, único cativo arrolado entre as posses desse falecido. ${ }^{96}$ Joaquim Assunção crioulo forro era morador em Mata Cavalos e proprietário de Francisco Angola. Na ocasião da morte desse escravo, Joaquim se encontrava preso na cadeia da cidade de Mariana "por dívidas". 97

A posse de escravos, mesmo que não fosse uma característica definidora da ascensão econômica, também poderia indicar melhores condições de vida. Ainda assim, é importante lembrar que até aqueles libertos que vivenciaram melhores situações, que adquiriam fortunas mais avultadas, não tiveram um padrão de vida muito diferente daqueles vigentes na sociedade mineira colonial. ${ }^{98}$ Sem dúvida alguma, a aquisição de escravos foi marcante entre os que legaram posses. Por meio dos registros de óbitos, pretende-se verificar indícios da propriedade escrava dos egressos do cativeiro, no período compreendido como de queda da atividade aurífera e a reestruturação da economia a partir das atividades agrícolas. As limitações dessas fontes para esse tipo de estudo são conhecidas, mas, como demostram outros historiadores, elas são úteis para levantar alguns indicadores da incidência dos forros no conjunto de senhores de escravos. ${ }^{99}$

É importante ressaltar que os óbitos de escravos de proprietários livres foram coletados a partir do "levantamento abreviado" proposto por Louis Henry para os registros paroquiais. ${ }^{100}$ Optou-se por coletar apenas o número de mortes sem a preocupação com a denominação desses senhores, diante das possíveis dificuldades de correlação a partir dos homônimos. Estamos cientes das alterações desses números frente à possibilidade de repetição de nomes dos senhores livres. Não obstante, se considerarmos que os estudos sobre a posse de

\footnotetext{
${ }^{96}$ ACSM, Inventário, Códice 66, Auto 1421.

${ }^{97}$ Registro de óbito, AEAM, Livro: Q-15, Data do óbito: 02/02/1761, p. 38. A precariedade das cadeias das cidades coloniais levou presos a contraírem doenças que ocasionavam mortes. Além das péssimas das intalações que ocupavam, muitos eram pobres e, portanto, desprovidos de alimentos. SOUZA, Laura de Mello e. Desclassificados do ouro: a pobreza mineira no século XVIII. Rio de Janeiro: Graal, 1982, 118-119. Doenças como "tísica pulmonar", "hepatite”, "hidropsia", "aneurisma”, "congesto cerebral”, "congestão do sangue no coração", "grastrinterite", "crâncro no estômago", dentre outras, foram detectadas a partir de autos de exames de cadáveres de presos falecidos na cadeia de Mariana, no século XIX. SOUZA, Elizabeth Valéria Rouwe de; SOUZA, Marcos Aurélio Rouwe de. "Reconhecimento dos autos de exames de cadáveres". In: GONÇALVES, Andréa Lisly; OLIVEIRA, Ronald Polito. (Org.). Termo de Mariana: história e documentação. Mariana: Imprensa Universitária da UFOP, Volume II, 2004, p.189-191.

${ }^{98}$ LEWCOWICZ, "Herança e relações familiares”, p.107.

${ }_{99}$ Adotamos os mesmos métodos utilizados por Iraci Del Nero e Vidal Luna em estudo sobre a Freguesia de Antônio Dias e a Comarca do Serro Frio. Esses autores trabalharam com os óbitos para a Fregeusia e com os registros de capitação para a Comarca. Justificaram a utilização desses registros devido à escassez de informações quantitativas para o estudo da escravaria brasileira. Alertaram também para a falta de pretensão quanto ao estabelecimento de "quantidades, índices ou relações definitivas", propondo apenas indicadores "suficientes ao levantamento de tendências mais evidentes e marcantes". LUNA; COSTA, "A presença do elemento forro", p. 837.

${ }^{100}$ HENRY, Louis. "O levantamento dos registros paroquiais e a técnica de reconstituição de famílias.” In: MARCÍLIO, Maria Luiza. Demografia Histórica: orientações técnicas e metodológicas. São Paulo: Pioneira, 1977, (Coleção Novos Umbrais), p.41-63.
} 
escravos em Minas Gerais apontam para a tendência de números reduzidos, de 1 a 5 cativos por proprietário, ${ }^{101}$ não teríamos tantas alterações no que se refere à correlação entre os dados de senhores forros e livres. Com relação aos libertos, também foram encontrados homônimos. Ao longo desse período, apenas sete nomes se repetiram, sendo que, desses, quatro são indicados em datas aproximadas; os três restantes apresentam datas de vinte a trinta anos de diferença, sugerindo a possibilidade de não se tratar da mesma pessoa. Dessa forma, optamos por não alterar a totalização desses dados, pelo fato de os homônimos serem pouco significativos, quase não afetando os resultados.

Na Tabela 7 encontra-se o resultado dos óbitos de escravos falecidos em Mariana na segunda metade do século XVIII. Desses, destacamos o contingente de cativos pertencentes à população liberta, por meio da indicação “Escravos de Senhores Libertos”, e classificamos os demais assentos como de "Escravos de Senhores Livres”. O objetivo principal dessa tabela é verificar a incidência de escravos falecidos que pertenciam aos egressos do cativeiro, com o intuito de destacar seu percentual no conjunto de escravos falecidos de maneira geral.

Tabela 7 - Indicação da condição senhorial nos óbitos de escravos de Mariana, 1751 a 1800.

\begin{tabular}{cccccc}
\hline Data & $\begin{array}{c}\text { Escravos } \\
\text { de } \\
\text { Senhores } \\
\text { Libertos }\end{array}$ & $\begin{array}{c}\text { \% Escravos de } \\
\text { Senhores } \\
\text { Libertos }\end{array}$ & $\begin{array}{c}\text { Escravos } \\
\text { de } \\
\text { Senhores } \\
\text { Livres }\end{array}$ & $\begin{array}{c}\text { \% Escravos de } \\
\text { Senhores } \\
\text { Livres }\end{array}$ & $\begin{array}{c}\text { Total de } \\
\text { óbitos de } \\
\text { escravos }\end{array}$ \\
\hline $1751-1760$ & 44 & $7,62 \%$ & 533 & $92,38 \%$ & 577 \\
\hline $1761-1770$ & 17 & $4,14 \%$ & 393 & $95,86 \%$ & 410 \\
\hline $1771-1780$ & 22 & $3,25 \%$ & 654 & $96,75 \%$ & 676 \\
\hline $1781-1790$ & 16 & $2,27 \%$ & 686 & $97,73 \%$ & 702 \\
\hline $1791-1800$ & 30 & $3,64 \%$ & 792 & $96,36 \%$ & 822 \\
\hline $\begin{array}{l}\text { Fonte: Registros de óbitos - Arquivo Eclesiástico da Arquidiocese de Mariana - Livros: Q-10, Q-11, Q-13, } \\
\text { Q-14, Q-15, Q-16, Q-17 e Q-18. }\end{array}$
\end{tabular}

A partir desses dados, percebemos a presença maciça de óbitos de escravos de senhores livres em relação aos libertos; enquanto os livres foram representados entre 92 e

\footnotetext{
${ }^{101}$ LUNA, Francisco Vidal. Minas Gerais: escravos e senhores - análise da estrutura populacional e econômica de alguns centros mineratórios (1718-1804). São Paulo: Publicado para o Instituto de Pesquisas Econômicas, 1981, p.124; LEWCOWICZ, “Herança e relações familiares”, p.102.
} 
97\%, o percentual de proprietários forros não ultrapassou $8 \%$ dos registros encontrados. ${ }^{102}$ Os libertos somavam 129 pessoas, sendo 87 mulheres e 42 homens.

Conforme já mencionamos, em Minas Gerais, o número de escravos por proprietário era reduzido. A difusão do escravismo não implicou o ingresso de todos os ex-escravos na classe senhorial. Sua participação nesse grupo oscilou no decorrer da segunda metade do século XVIII, com uma tendência declinante, mesmo diante do aumento do número de mortes de escravos na sociedade, conforme já abordamos anteriormente.

É importante lembrar que, nas décadas de 1760 e 1770, segundo a historiografia, houve uma queda das concessões de alforrias, o que conseqüentemente deveria manter o índice de óbitos de escravos mais altos. Mas, percebemos um movimento declinante das mortes desses sujeitos com relação ao período anterior.

Os forros reproduziam os padrões de escravização dos brancos. Não foram mais benévolos no tratamento com os seus escravos; quando ocorriam alforrias, eram quase sempre seguidas de contrapartida pecuniária. ${ }^{103}$ Isso pode ser percebido a partir das principais dívidas ativas desses sujeitos, decorrentes em geral de libertação onerosa. Os valores poderiam ser revertidos ao pagamento de possíveis dívidas, ou simplesmente servir de dotes para as filhas nubentes $^{104}$.

As alforrias por coartações se faziam constamentemente presentes nas disposições testamentárias dos libertos e nas informações dos inventários. Talvez tenha sido a forma encontrada pelo preto forro Antônio Angola, “que foi de Quitéria de Faria preta forra”. Ele faleceu no dia 17 de abril de 1794, com todos os sacramentos, e foi sepultado no cemitério da matriz. $^{105}$

Muitos óbitos de escravos de proprietários emancipados também dizem respeito a crianças, o que, de certa forma, sugere a presença de vida familiar entre cativos desses senhores. Em 26 de março de 1781, faleceu Mariana “parvola”, filha de Ana mina escrava de

\footnotetext{
${ }^{102}$ Para a freguesia de Antônio Dias, em Vila Rica, foram encontrados percentuais que variaram entre 3\% e 14,6\% senhores forros para as amostragens do século XVIII (1743-45, 1760-62, 1799-1801, 1809-11). LUNA; COSTA, “A presença do elemento forro”, p. 837.

${ }^{103}$ Analisando testamentos e inventários de libertos de Mariana do século XVIII, Ida Lewcowicz percebeu que foram poucos os que deixaram escravos alforriados nesses registros. Em suas palavras, "apenas quatro receberam sua carta de liberdade, sem qualquer ônus pecuniário". LEWCOWICZ, "Herança e relações familiares", p.110.

${ }^{104}$ MÓL, Claudia Cristina. Mulheres forras: cotidiano e cultura material em Vila Rica (1750-1800). Dissertação de Mestrado, FAFICH/UFMG, Belo Horizonte, 2002, p. 32.

${ }^{105}$ AEAM, Registro de óbito, Livro: Q-10, p. 33v.
} 
Feliciana Lopes, crioula forra. Tudo indica que Feliciana seria proprietária de Mariana, que foi “batizada em casa por necessidade pelo Guarda Mor Martinho Ferreira dos Santos”. 106

A posse de escravos entre os libertos de Mariana variou entre 1 a 13, embora a predominância foi de menos de 5 por proprietário. ${ }^{107}$ Os cativos geralmente compunham a maior parte da soma do monte-mor desses sujeitos. Contudo, em alguns casos, a indicação de posse superior a um escravo geralmente tratava de uma mãe e seus filhos, não necessariamente envolvendo maior investimento na propriedade escrava. Dentre essas pessoas estão Antônia e Tereza. Antônia Rodrigues Lima, preta forra, possuía uma escrava de nação mina, chamada Felícia, de 30 anos, mais seus três filhos crioulos, Francisco, de 15 anos, Serafim, de 3 e Maria de apenas um mês. ${ }^{108}$ Tereza Tavares, preta forra, moradora no Rosário, era proprietária de Josefa Mina, provavelmente a mãe, e seus filhos, Manoel crioulo de dois anos e Vicente cabra de 10 meses. ${ }^{109}$

A propriedade escrava era responsável pela maior parte da soma do monte-mor desses sujeitos, mas, ainda assim, muitos cativos possuíam valores menores que os de mercado, por serem doentes ou apresentarem algum tipo de deficiência. Os dois escravos de Joana da Costa Meneses compunham o maior valor do seu patrimônio, $100 \$ 000$ réis, em uma soma de seus bens de 141\$200 réis. No entanto, tratava-se de Micaela Ladana, de 30 anos, “com moléstia” e Felipe crioulo, de 15 anos “aleijado dos pés”. ${ }^{110}$ Entre os sete escravos de Felipe de Godoi, dois apresentavam valores inferiores aos demais, Gonçalo de nação Angola, de 25 anos, que parecia apresentar algum problema alérgico, descrito como "um formigueiro" ou coceira, e Antônio de nação Angola, “por ter sido mal encanado quando foi quebrado, por cujo motivo não pode dar tão bom serviço como poderia sem o dito incoveniente”. ${ }^{111}$ Além desses fatores, havia também escravos com idades bem avançadas entre as posses dos libertos.

As características acima citadas tendiam a desvalorizar o preço e a serventia de alguns escravos pertencentes a esses senhores, o que eventualmente poderia ser secundário, haja vista que a inserção do egresso do cativeiro na categoria de proprietários de escravos se dava, em grande medida, pela demarcação de sua nova posição na sociedade colonial escravista.

\footnotetext{
${ }^{106}$ AEAM, Registro de óbito, Livro: Q-10, p. 228.

${ }^{107}$ Informações contidas nos testamentos e inventários.

108 ACSM, Inventário, Códice 101, Auto 2104, 1776.

109 ACSM, Testamento, Livro 64, 1753. Vimos que relações de afeto eram cultivadas pelos libertos com relação aos filhos de suas escravas.

${ }^{110}$ ACSM, Inventário, Códice 45, Auto 1018, 1758.

111 ACSM, Inventário, Códice 117, Auto 2336, 1786.
} 


\subsection{Os libertos pobres}

Na segunda metade do século XVIII, mesmo com a aparente diminuição das taxas de manumissão, houve uma representativa população forra e de seus descendentes, seguindo o padrão das importantes regiões mineradoras da Capitania das Minas. ${ }^{112}$ Eram africanos que alcançavam a carta de liberdade, crioulos nascidos livres ou igualmente alforriados, ou pardos e mulatos gerados a partir do intercurso sexual entre homens brancos e negras livres ou escravas, que acabaram por caracterizar o fenômeno da mestiçagem. ${ }^{113}$

Em se tratando dos libertos, depois de alcançarem a alforria, a sobrevivência era sem dúvida alguma, a principal preocupação desses sujeitos, pois “dispor de si” representava autonomia, mas também demandava constante afinco da parte de quem a conquistava. A sobrevivência, por sua vez, passava pela inserção econômica e social e pela certeza de que, optando ou não pela mudança do local onde vivera o cativeiro, o êxito das suas condições futuras estava relacionado ao exercício de alguma função e ao estabelecimento de determinadas conexões nas redes hierárquicas da sociedade na qual se pretendia fixar.

É certo que parte dos escravos alforriados já desenvolvia algum tipo de ocupação, geralmente associada à função executada enquanto cativos, ou ainda possuía vínculos com aqueles que os amparavam na iminência da alforria. No entanto, os contextos sociais e econômicos na colônia foram marcados pela instabilidade, fazendo com que a trajetória de vida de um sujeito também fosse engendrada por experiências diferenciadas. Uma pessoa que alcançava a liberdade poderia ascender economicamente, pois a pobreza não era inerente à condição de ex-escravo, mas, ao mesmo tempo, o fato de adquirir posses não representava barreiras para a decadência econômica.

Segundo Laura de Mello e Souza, a imagem de opulência criada nas Minas muito guardava da construção ideológica, pois a riqueza propriamente dita era privilégio de poucos. A posse de escravos, por exemplo, é que definia o tamanho do território a ser explorado, mas como a propriedade de escravos se deu de maneira pulverizada, foram poucos os senhores que concentraram maior número de cativos e datas minerais mais extensas. Nos termos da autora, “mais da metade das lavras estava concentrada nas mãos de menos de 1/5 dos proprietários de negros”, ou seja, nas mãos de pequenos garimpeiros e faiscadores. ${ }^{114}$

\footnotetext{
${ }^{112}$ SOUZA, Laura de Mello e. Desclassificados do ouro, p. 143.

${ }^{113}$ ALENCASTRO, Luiz Felipe de. O trato dos viventes. Formação do Brasil no Atlântico sul. Séculos XVI e XVII. São Paulo: Companhia da Letras, 2000, p.345-346.

114 SOUZA, Laura de Mello e. Desclassificados do ouro, p. 26-27.
} 
As regiões da mineração, portanto, apresentaram uma distribuição do capital mais ampliada que as regiões do açúcar, mas com maiores índices de homens com "baixo poder aquisitivo e pequena dimensão econômica”. Esse fator contribuiu para que houvesse "um maior número de pessoas que dividiam a pobreza", ${ }^{115}$ e que, sobretudo, poderiam se inserir nessa condição, uma vez que homens destituídos de recursos encontravam mais dificuldades para manter seus negócios.

Determinar o conceito de pobreza é uma tarefa complexa em qualquer sociedade; em se tratando da colonial, as dificuldades parecem aumentar. De maneira geral, era definida como o estado de nada possuir, ${ }^{116}$ ou simplesmente medida pelos legados materiais, como jóias, número de escravos, propriedade, etc. Seja como for, a ausência, ou presença, de bens permite que se avalie a "pobreza relativa”. ${ }^{117}$ Mas, segundo Bronislaw Geremek, as "noções de sucesso e insucesso material” não são os melhores mecanismos para se definir essa condição, pois, nas sociedades modernas, o estatuto social teve maior peso na vida dos indivíduos do que uma situação material desfavorecida. A pobreza esteve associada a um modo de vida que interagia com diferentes contextos de determinada população, como os políticos, econômicos e sócio-culturais. ${ }^{118}$

Do ponto de vista político, a administração colonial em geral veiculou uma imagem negativa dos libertos. Essa idéia foi recuperada pelos autores que estudaram a sociedade colonial pelo viés da ideologia da dominação, afirmando que os egressos do cativeiro tendiam a se inserir na pobreza por se mostrarem desconectados da ordem construída pelo escravismo, pois engrossavam a camada de mão-de-obra livre, pouco absorvida e sujeita a todo tipo de ocupação esporádica na economia. Esse caráter de instabilidade acabou gerando uma idéia de desclassificação dessa camada emergente por parte da elite local, que tentava consolidar a ordem pública gerenciando os aparatos administrativos. ${ }^{119}$

Segundo esse prisma, a desclassificação também foi entendida como vadiagem. O vadio, por sua vez, seria potencialmente qualquer indivíduo desprovido de trabalho. ${ }^{120}$

\footnotetext{
115 SOUZA, Laura de Mello e. Desclassificados do ouro, p. 29-30.

${ }^{116}$ CANABRAVA, Alice. "Uma economia de decadência: os níveis de riqueza na capitania de São Paulo, 176567”. Revista Brasileira de economia, v. 26, n²4, out-dez, 1972 p.95-123.

117 As pesquisas que utilizaram documentos como testamentos e inventários post-mortem tendem a tratar da riqueza relativa. Carla Almeida comparou as somas dos bens deixados para que fosse analisada a pobreza relativa, conforme resultados apresentados no quarto capítulo de sua tese de doutoramento, "Hierarquização social: a sociedade polarizada”. ALMEIDA, Carla Maria Carvalho de. Homens ricos, homens bons: produção e hierarquização social em Minas Colonial: 1750-1822. Tese de Doutorado, UFF, Niterói, p. 168-224.

${ }^{118}$ GEREMEK, Bronislaw. A piedade e a força: história da miséria e da caridade na Europa. Lisboa: Terramar, 1987, p.8-10.

${ }^{119}$ SOUZA, Desclassificados do ouro, 1986. LARA, Fragmentos Setecentistas, 2004.

120 SOUZA, Desclassificados do ouro, p.66.
} 
Poderiam ser homens livres de pele escura ou libertos, “que não tinham ofício” e "que podiam criar tumultos ou agir de forma ignorante”. ${ }^{121}$ Essas interpretações tendem a considerar que o estigma da escravidão associado à falta de ocupação atuava na vida dos libertos como vetor da degradação social, chegando mesmo a serem vistos como "suspeitos" de crimes e alvo de prisões. $^{122}$

Se seguíssemos à risca a documentação administrativa da Mariana colonial sem considerarmos outras informações que registram momentos de vida desses sujeitos, também tenderíamos a reproduzir essas interpretações, pois algumas tensões foram documentadas na década de 1750 indicando que parte da população liberta estava associada a distúrbios ocorridos e se transformou em motivo de preocupação por parte da vereança.

Em 1755, os oficiais da câmara da cidade enviaram a Portugal uma correspondência solicitando providências pelos “incômodos e desassossegos" que os vassalos estavam experimentado devido à má conduta de determinados grupos na sociedade. $\mathrm{O}$ documento de 5 de maio menciona os "contínuos insultos e vexames de que são vítimas os moradores por parte dos negros, negras e mulatos forros.” Associados aos negros fugidos, os libertos foram acusados de roubos, mas também de protegê-los, “facultando-lhes armas e pólvora para efetuarem assaltos”. ${ }^{123}$ As autoridades pediam providências à Coroa Portuguesa quanto às crescentes taxas de alforrias concedidas e à restrição dessas pessoas ao acesso às armas, por se sentirem temerosos com a possibilidade de ocorrerem revoltas. Sugeriram a adoção de livros que registrassem a movimentação dos libertos nas freguesias a partir da apresentação da carta de liberdade.

Outra queixa dessa natureza foi reproduzida nos anos seguintes. É o que indica o documento de 28 de janeiro de 1756, um "parecer do procurador da Coroa sobre as desordens praticadas pelos mulatos e negros forros no termo da cidade de Mariana”. ${ }^{124}$ A administração marianense colonial considerou que os libertos, aliados aos escravos fugidos, representavam insegurança para a população local. Esse discurso certamente mostra tensões entre esses sujeitos e os representantes da Coroa Portuguesa, que mais uma vez tentava propagar a imagem de uma classe sem ocupação, temida, associada à violência, desordem e envolvimento em atividades ilícitas. ${ }^{125}$

\footnotetext{
${ }^{121}$ LARA, Fragmentos Setecentistas, 2004, p. 186.

122 HUNOLD, Sílvia Lara. Campos de violência: escravos e senhores na Capitania do Rio de Janeiro, 1750-1808. Rio de Janeiro: Paz e Terra, 1988, p. 276.

${ }^{123}$ AHU, Projeto RESGATE/MINC-AHTT, caixa 67, documento n ${ }^{\circ}: 65,1755$.

${ }^{124}$ AHU, Projeto RESGATE/MINC-AHTT, caixa 69, documento no: 25, 1756.

${ }^{125}$ Esse tipo de imagem também era propagado em outras regiões da América Portuguesa. Em estudo sobre o Rio de Janeiro, Leila Mezan Algranti destacou que “(...) a vida dos forros era totalmente desequilibrada: ora
} 
É certo que libertos, assim como parte da população livre, envolveram-se em conflitos, pois alguns acabaram presos na cadeia da cidade de Mariana, local onde faleceram, como aconteceu com João Francisco, em $1775^{126}$, Valentim dos Santos, em $1779^{127}$, e Manoel da Silva, em 1796. ${ }^{128} \mathrm{E}$ ainda, aqueles que eram considerados criminosos, como Afonso ${ }^{129} \mathrm{e}$ Francisco $^{130}$. Perder a vida em brigas eventuais foi outra realidade que alguns conheceram, como Leandro Pinto crioulo forro, que morreu de facadas nas costas ${ }^{131}$ e com Manoel Botelho cabra forro, que foi achado morto em Mata Cavalos e foi sua morte provocada por "uma ferida mortal que lhe fizera". ${ }^{132}$ Além desses, foram localizados registros de homens encontrados mortos na região, cuja condição social era desconhecida, mas ainda assim, identificados por serem "pretos”, como um cadáver encontrado "com um pedaço de corrente no pescoço”, no ano de $1768 .^{133}$

Ainda que esses dados indiquem envolvimento dos libertos em conflitos, não sabemos quais motivos geraram a morte desses sujeitos. Esses casos, contudo, são apenas pontuais no universo de informações levantadas. Ademais, nenhuma indicação de pobreza teve associação direta com a desclassificação social ou com a marginalidade, mas sim com a impossibilidade de exercer algum tipo de ocupação, conforme veremos posterioremente. De maneira geral, os conflitos em que os libertos estiveram envolvidos não podem ser explicados unicamente pelo viés da desordem e violência; algumas demandas, ainda que fossem prejudiciais à sua honra, estariam ligadas apenas a questões de restrições financeiras ou incovenientes cotidianos. Essas eram, portanto, contendas de âmbito civil, e não de natureza criminal. Por vezes, muitas das acusações de desvios de conduta nem mesmo chegaram a ser comprovadas. $^{134}$

empregados, ora vadios, enfrentando constantemente a fome e a miséria, encontravam no crime, nas brigas e desordens uma válvula de escape, uma solução para os seus problemas”. ALGRANTI, Leila Mezan. O feitor ausente; estudo sobre a escravidão urbana no Rio de Janeiro de 1808 a 1822. Petrópolis: Vozes, 1988. p. 128.

${ }_{126}$ AEAM, Registro de óbito, Livro: Q-16, Data do óbito: 09/05/1775, p. 49.

${ }_{127}$ AEAM, Registro de óbito, Livro: Q-17, Data do óbito: 26/03/1779, p. 16.

${ }^{128}$ AEAM, Registro de óbito, Livro: Q-18, Data do óbito: 16/08/1796, p. 131v.

${ }^{129}$ AEAM, Registro de óbito, Livro: Q-17, Data do óbito: 30/07/1786, p. 97v.

${ }^{130}$ AEAM, Registro de óbito, Livro: Q-17, Data do óbito: 26/09/1781, p. 49.

${ }^{131}$ AEAM, Registro de óbito, Livro: Q-10, Data do óbito: 24/06/1766, p. 175.

${ }^{132}$ AEAM, Registro de óbito, Livro: Q-10, Data do óbito: 17/03/1767, p. 112v.

${ }^{133}$ AEAM, Registro de óbito, Livro: Q-10, Data do óbito: 13/03/1768, p. 62.

${ }^{134}$ Não obstante a esses fatores, é importante lembrar que estudiosos que investigaram aspectos da vida desses sujeitos demonstraram que uma parcela considerável adquiriu posses e certo destaque na sociedade, fatores que tenderiam de distanciá-los dos padrões de desclassificação supostamente identificados. MÓL, Mulheres forras. PAIVA, Eduardo França. Escravidão e universo cultural na colônia - 1716-1789. Belo Horizonte: UFMG, 2001, PAIVA, Eduardo França. Escravos e libertos nas Minas Gerais do século XVIII; estratégias de resistência através de testamentos. São Paulo: Annablume, 1995. 
Há uma grande dificuldade de se encontrar documentação que retrate a vida das pessoas pobres e libertas. A documentação utilizada é quase sempre oficial, pois, na maioria das vezes, esses indivíduos não deixavam registros próprios. A alfabetização nesse período também era muito restrita e, tratando-se da população liberta, a situação se agravava ainda mais, devido à dificuldade de acesso à educação comum a esse grupo ${ }^{135}$. Dessa forma, as informações existentes nos permitem determinar apenas indícios de “pobreza”, com possibilidades de análise limitadas.

As condições sócio-culturais que definiam a pobreza foram bem colocadas por Maria Beatriz Nizza da Silva, que percebeu uma variação quanto aos critérios adotados pelos recenseadores civis e eclesiásticos na sociedade colonial. Esses critérios foram definidos basicamente por três tipos: a pobreza oficial, a pobreza visível e a pobreza sentida. ${ }^{136}$

A pobreza oficial pode ser definida como aquela encontrada em documentos como as listas nominativas de habitantes, que distinguia pessoas pobres e pessoas que viviam de esmolar. Mas também havia uma tendência dos vigários das paróquias em classificar como pobre o indivíduo que se mantinha apenas com o que era produzido por seu trabalho. ${ }^{137} \mathrm{~A}$ pobreza visível foi constatada em outro tipo de documentação, pois se tratava de alguém que não fazia testamento, mas que tinham seus parcos bens recolhidos pelo provedor dos Defuntos dos Ausentes no caso do falecimento. Da mesma forma, foi percebida a pobreza das mulheres escolhidas pelos párocos para receber doações de falecidas ricas, fossem enjeitadas, órfãs e filhas de criação, que eram assistidas por pessoas de posses. ${ }^{138}$ A pobreza sentida se referia a indivíduos que possuíam bens e até mesmo ocupação, mas que por algum motivo, necessitavam de meios para sobreviver, como as mulheres abandonadas pelos maridos, que faziam queixas nos Tribunais Eclesiásticos por se encontrarem em situação pecuniária restrita. Certamente foi esse tipo de pobreza que Rita Botelha preta forra vivenciou. ${ }^{139}$

Depois de comprar o escravo Fernando, Rita com ele se casou e em seguida o alforriou. O contrato de casamento foi firmado com a condição de que os bens da liberta só entrariam para a divisão caso tivessem filhos. As posses englobavam um rancho coberto de capim, terras de mineração, ferramentas, escravos, roupas, acessórios, trastes de casa, além de ouro procedente das lavras que o casal explorava. Após algum tempo, Rita se afastou de sua

\footnotetext{
${ }^{135}$ SOUZA, Desclassificados do ouro, p.15.

${ }^{136}$ A autora de empenhou em destacar a pobreza feminina, uma vez que se mostrava mais explícita na documentação. SILVA, Maria Beatriz Nizza da. "Pobreza feminina no Brasil colonial”. Revista de Ciências Históricas, Universidade Portucalense, Vol. XI, 1996, p.91-100.

${ }^{137}$ Definições empregadas a partir da análise de uma lista de habitantes da freguesia de S. Pedro da cidade da Bahia, feita por um capitão-mor da região. SILVA, "Pobreza feminina no Brasil colonial”, p. 101.

${ }^{138}$ SILVA, "Pobreza feminina no Brasil colonial”, p. 97.

${ }^{139}$ ACSM, Ação Cível, Códice 303, Auto 7302.
} 
casa e se abrigou em residência de uma filha argumentando que o marido possuía amásias, e, além disso, a maltratava. Passados dois anos, essa liberta já havia entrado com um libelo de divórcio no Juízo Eclesiástico, mas também procurou a justiça de Mariana para cobrar do esposo a assitência de seis vinténs de ouro diários, para valores despendidos com alimentos, mais 32 oitavas, para despesas com o vestuário.

No primeiro momento, Fernando foi condenado pela justiça; no entanto, ele acabou apresentando embargos daquela primeira decisão. Seus argumentos se opunham aos da esposa, ao declarar que Rita o havia deixado por indução de pessoas “mal afeiçoadas dele”, e por outras argumentações infundadas. Queria mostrar à justiça que era um homem trabalhador, mas que seus rendimentos eram modestos, a ponto de serem quase insuficientes para cobrir os gastos com sustento e despesas gerais, a saber, dívidas, pagamentos feitos a escravos de aluguel, gastos com os próprios escravos, manutenção dos objetos de trabalho, alimentação, vestimentas, dentre outros.

Não conhecemos o desfecho dessa ação, mas sabemos que se associa a um caso de pobreza sentida por se tratar de uma mulher de posses, mas que passou por momentos de necessidade ao se afastar de seu marido.

A utilização desses critérios tendeu a proteger mais as mulheres, que contavam com instituições que costumavam mantê-las, ou simplesmente com pessoas que pudessem favorecê-las. É possível perceber que os conceitos mudavam de acordo com os interesses de quem produzia os registros que indicavam essa condição. Mas, para Maria Beatriz, alguns fatores foram definitivos, como a predominância da maior incidência de pobreza feminina em relação à masculina. Em suas palavras,

O homem só era pobre quando cego, aleijado ou velho sem família. Fora dessas situações, era simplesmente qualificado como vadio, vagabundo ou ocioso quando não obtinha os meios de sobreviver. A pobreza masculina era causada por uma natureza preguiçosa, enquanto a pobreza feminina não recebia uma conotação pejorativa por decorrer da fragilidade da mulher, da sua situação desprotegia na ausência de um apoio masculino. Se a pobreza decorrente de ociosidade estava do lado da marginalidade, a pobreza era uma realidade que a sociedade colonial aceitava e tentava remediar usando estratégias várias desde a proteção institucional via Misericórdias até à autorização para esmolar. ${ }^{140}$

A mendicância somente era permitida a pessoas incapazes de executar qualquer tipo de trabalho. Em Mariana, as condições de pobreza também foram definidas por instituições

\footnotetext{
${ }^{140}$ SILVA, “Pobreza feminina no Brasil colonial”, p. 99.
} 
como a Câmara Municipal, que, pelo menos do ponto de vista legal, deveria controlar a autorização para se pedir esmolas. É o que mostra uma "carta provisão", passada a um Juiz de Vintena:

(...) de suspensão para sempre, e de trinta dias na cadeia e debaixo da mesma pena prenderá a todo e qualquer pobre que no seu distrito andar pedindo esmola, exceto os cegos, aleijados, e velhos de idades que não possam trabalhar ou que trouxerem provisão para o dito efeito (...). ${ }^{141}$

As informações contidas nesse fragmento permitem formular outra caracterização para os pobres de Mariana, que confronta com a noção demonstrada no documento anteriormente mencionado. Aqui, o pobre estava totalmente integrado à sociedade de ordens e não localizado à sua margem e associado à vadiagem. A pobreza também era necessária à promoção da caridade autônoma, tão prezada à salvação da alma dos potentados, que se obrigavam a deixar esmolas aos necessitados, como forma de se eximirem de seus pecados. Era um mecanismo que propagava o dom, o sacrifício. ${ }^{142}$ Além desses fatores, a mendicância exercida nas cidades não necessariamente era indício de pobreza, pois, organizações como as irmandades geralmente incumbiam alguns dos confrades de praticá-la como instrumento de angariação de recursos, que seriam revertidos à assistência de irmãos necessitados, ou à contrução de seus templos.

De fato, percebemos que as doenças eram um atributo que associava as pessoas à pobreza. O auxílio no momento da morte geralmente era dado por conhecidos, familiares e ainda pelas irmandades. Em 13 de junho de 1778 faleceu Manoel Rodrigues Roza, crioulo forro, “doente sempre e pobre”, tratado “pelo amor de Deus” pelo Reverendo Inácio Lopes da Silva, com quem morava. ${ }^{143}$ Assim também faleceu Domingos, preto forro, aleijado que morava em casa do Capitão Manoel Camelo ${ }^{144}$ e Luiz, preto forro, cego. ${ }^{145}$ Roza Maria Machada, parda forra, “pobre entrevada”, também faleceu em 1778, e provavelmente sobrevivia com a ajuda de pessoas próximas que a apoiaram ainda no momento de sua morte, com a concessão de uma "sepultura que lhe deram pelo amor de Deus”. ${ }^{146}$

Conforme procuramos mostrar por meio dos registros de óbitos existentes no Arquivo Eclesiástico da Arquidiocese de Mariana, essa população liberta e pobre, durante a segunda metade do século XVIII, tendeu a crescer. Nessa documentação é bem clara a

\footnotetext{
${ }^{141}$ AHCMM, Livro 216, página 5, 1787.

${ }^{142}$ GEREMEK, A piedade e a força, p.289.

${ }^{143}$ AEAM, Registro de óbito, Livro: Q-17, p. 06.

${ }_{144}$ AEAM, Registro de óbito, Livro: Q-17, p. 101.

145 AEAM, Registro de óbito, Livro: Q-18, p. 12.

${ }^{146}$ AEAM, Registro de óbito , Livro: Q-17, p. 06.
} 
definição a respeito da condição social dos indivíduos, fato que nos possibilitou destacar a população forra falecida. É evidente que, como todos os tipos de registros, estes também apresentam problemas, principalmente se pensarmos na possibilidade de não terem sido registrados todos os óbitos, mesmo se tratando de uma região urbana, como é o espaço determinado no presente trabalho. Outro ponto a ser considerado é que, devido às restrições dessas fontes, não podemos caracterizar o nível de pobreza em que vivia essa população; apenas nos foi permitido saber os indícios de libertos pobres na sociedade marianense a partir da identificação feita pelo pároco.

No caso de pessoas mais pobres, o enterro era feito "pelo amor de Deus”, "por caridade”, "grátis”, ou, simplesmente, havia a indicação de "pobre” ou "mendicante”, como podemos perceber em um exemplo a seguir:

Aos dez de julho de mil setecentos oitenta e um faleceu confessado e ungido Francisco preto forro pobre; foi encomendado e sepultado na Capela do Rosário dos Pretos de que fiz este assento. ${ }^{147}$

Renato Pinto Venâncio, ao trabalhar com os registros de óbitos da Catedral do Rio de Janeiro, considerou como indigentes e vivendo em miséria absoluta as pessoas enterradas “pelo amor de Deus”, ao passo que os considerados como pobres, eram pessoas que viviam no limiar dessa condição. ${ }^{148}$

A partir do levantamento dos óbitos de Mariana foi possível perceber que não só os libertos, mas também pessoas livres eram indicadas nos assentos como pobres. A partir dessa característica destacamos o percentual de libertos entre o conjunto de falecidos que apresentavam essa condição no momento da morte, conforme especificado na Tabela 8:

\footnotetext{
${ }^{147}$ AEAM, Registro de óbito, Livro: Q10, p.230.

148 VENÂNCIO, Renato Pinto. "Pobreza carioca: uma proposta de avaliação quantitativa, 1750-1808”. Comunicação apresentada no II Seminário de História Quantitativa e Serial, IPEA/PUC/NEASPOC, Belo Horizonte, 2001, p.14.
} 
Tabela 8 - Número de óbitos de libertos pobres em Mariana, 1751 a 1800.

\begin{tabular}{cccccc}
\hline Data & $\begin{array}{c}\text { Libertos } \\
\text { Pobres }\end{array}$ & $\begin{array}{c}\text { \% de Pobres } \\
\text { Libertos }\end{array}$ & $\begin{array}{c}\text { Pobres } \\
\text { Livres }\end{array}$ & $\begin{array}{c}\text { \% Livres } \\
\text { Pobres }\end{array}$ & Total \\
\hline $1751-1760$ & 6 & $8,21 \%$ & 67 & $91,79 \%$ & 73 \\
\hline $1761-1770$ & 12 & $10,90 \%$ & 98 & $89,1 \%$ & 110 \\
\hline $1771-1780$ & 70 & $46,35 \%$ & 81 & $53,65 \%$ & 151 \\
\hline $1781-1790$ & 53 & $43,80 \%$ & 68 & $52,6 \%$ & 121 \\
\hline $1791-1800$ & 69 & $61,06 \%$ & 44 & $38,94 \%$ & 113 \\
\hline
\end{tabular}

Fonte: Registros de óbitos - Arquivo Eclesiástico da Arquidiocese de Mariana - Livros: Q-10, Q-11, Q-13, Q-14, Q-15, Q-16, Q-17 e Q-18.

É importante ressaltar que o número de pessoas enterradas como “pobres” teve um pequeno crescimento ao longo dos anos da segunda metade do século XVIII. No entanto, enquanto a categoria de livres diminuiu, a de libertos tendeu a crescer. Ainda que não tenhamos dados mais precisos sobre a população liberta nesse período, podemos considerar que a pobreza atingiu boa parte dos falecidos, pois os números são representativos para uma categoria que não era predominante entre a população de maneira geral (ver Tabela 4). A partir desses dados, tendemos a considerar que houve aumento da pobreza entre os indivíduos dessa mesma condição social.

De um total de 795 óbitos de libertos, os pobres somavam 210, representando 26,4\%. Na segunda metade dos setecentos, esses percentuais foram respectivamente, $12,7 \%, 16,2 \%$, 38,6\%, 23,4\% e 25,8\%. Percebemos que os anos de 1771 a 1780 apresentaram o maior índice, no entanto, podemos concluir que entre esse segmento, o aumento da pobreza não foi tão discrepante se comparado aos índices da população livre. Mas, ainda assim, essa condição foi representativa entre as pessoas dessa categoria social.

A diferença entre os sexos foi mínima entre os forros enterrados nessa condição 108 mulheres e 102 homens. Mas percebemos que a pobreza atingiu mais os homens, pois o número de mulheres falecidas era superior, 465 para 330. Dos 210 registros de pobres, encontramos apenas 11 pessoas casadas, sendo 5 homens e 4 mulheres, e 1 viúvo. Apesar da ausência de informações sobre os estado civil dos falecidos, podemos afirmar que a pobreza contribuiu para a ausência de relações conjugais legítimas. Além disso, é possível inferir que um liberto solteiro teria maiores possibilidades de morrer nessa condição do que aquele que possuía família. Proporcionalmente, os homens tinham maior propensão em incidir na pobreza. 
Mesmo sendo poucas as indicações de ofícios nos registros de óbitos analisados, retomaremos esse ponto anteriormente mencionado. Para alguns libertos, o domínio de um ofício viabilizou a ascensão econômica, mas também ocorreu o contrário. Antônio Teixeira da Costa, preto forro, natural da Costa da Mina, era proprietário de uma estalagem. Deixou seu solene testamento e foi sepultado na Igreja do Rosário, de onde era Irmão da mesma Irmandade. ${ }^{149}$ Outras atividades parecem indicar ascensão, como a de "oficial de ferreiro" do preto forro Thomas, que foi sepultado na Arquiconfraria de São Francisco, ${ }^{150}$ e do pardo forro José Jorge Cruz, casado com Esperança de Brito. ${ }^{151}$ Da mesma forma cabe sublinhar o caso de João Carvalho da Silva, preto forro, indicado na ata de óbito como "carniceiro"152 e falecido a 4 de julho de $1781 .^{153}$

No entanto, nem todos os libertos que possuíam profissão estiveram isentos de serem descritos em condições de pobreza no momento da morte. Francisco de Souza, pardo forro, casado com Josefa, parda forra, foi enterrado por esmola, por ser pobre, mesmo tendo sido "Guarda" em Mariana. ${ }^{154}$ O mesmo aconteceu com Pedro Borges, crioulo forro, "carapina"155.

Aos vinte e quatro de Agosto de mil setecentos e setenta e quatro faleceu com todos os sacramentos Pedro Borges crioulo forro carapina pobre foi encomendado acompanhado e sepultado na capella das Mercês de onde era Irmão e para constar fiz este assento. ${ }^{156}$

Ao ser indicado como pobre no momento da morte, não significa que um liberto vivenciou essa situação por toda a trajetória de sua vida, principalmente em se tratando de oficiais mecânicos, trabalhadores essenciais para a manutenção da vida na colônia.

Não seria correto afirmar que os dados encontrados, com a indicação de "pobre”, corresponderiam ao total da população carente existente nesse período. Em nosso levantamento, estamos tratando de uma parcela da população que poderia viver em condições de pobreza absoluta, ou simplesmente se enquadrava nas definições anteriormente abordadas, que lhes conferia o auxílio por meio da caridade, fosse em vida, ou no momento da morte. A

\footnotetext{
${ }^{149}$ AEAM, Registro de óbito, Livro: Q-16, Data do óbito: 04/12/1772, p. 145v.

${ }^{150}$ AEAM, Registro de óbito, Livro: Q-10, Data do óbito: 07/06/1771, p. 102v.

${ }^{151}$ AEAM, Registro de óbito, Livro: Q-17, Data do óbito: 13/05/1781, p. 44.

${ }^{152}$ Carniceiro, segundo Morais e Silva, é "o que mata, e vende carne no talho dou açougue”. SILVA, Antônio de Morais e. Dicionário da Língua Portuguesa: recopilado dos vocábulos impressos até agora. Lisboa: Tipografia Lacerdina, 1813, 2 volumes.

153 AEAM, Registro de óbito, Livro: Q-17, Data do óbito: 04/06/1781, p. 45.

${ }^{154}$ AEAM, Registro de óbito, Livro: Q-17, Data do óbito: 02/07/1782, p. 54v.

155 Carapina: “o mesmo que carpinteiro". SILVA, Antônio de Morais e. Grande Dicionário da Língua Portuguesa. 10a edição. Editorial Confluência, 1945.

${ }^{156}$ AEAM, Registro de óbito, Livro: Q-16, Data do óbito: 24/08/1774, p. 43.
} 
caridade era um dom concedido por parentes, vizinhos, mas também pelas irmandades, que sempre prestavam auxílio a um irmão necessitado. A preta forra Cosma Damiana recebeu todos os sacramentos e foi sepultada "pelo amor de Deus em sepultura que lhe deram os Irmãos de Santa Anna na sua Capela”. ${ }^{157}$ A parda forra Roza Maria Machada, entrevada e pobre, também foi enterrada em "sepultura da Irmandade do Santíssimo que lhe deram pelo amor de Deus”. 158

A solidariedade dos forros pode ser observada por meio dos registros de óbitos, que nos mostram a existência de forros residindo na mesma casa.

Ao primeiro dia do mês de maio do ano de mil setecentos e oitenta e dois faleceu com todos os sacramentos Joana Vieira preta mina forra, que morava em casa de Lourenço Payo preto forro morador neste Arraial. Foi sepultada dentro da Capela de Nossa Senhora do Rosário dos pretos. ${ }^{159}$

Mulheres forras podem ter usado o casamento com homens brancos como estratégia de enriquecimento e de ascensão social. ${ }^{160}$ Mas parece que nem todas se aproximaram somente dos homens mais abastados. Juliana de Mendonça, crioula forra, apesar de ser casada com Domingos Rodrigues Feliciano, foi enterrada como pobre em março de 1776:

Aos quinze de Março de mil setecentos e setenta e seis faleceu com todos os sacramentos Juliana de Mendonça crioula forra casada com Domingos Rodrigues morador no Inficionado foi sepultada e acompanhada na Capela das Mercês desta cidade. ${ }^{161}$

Uma situação ainda pior parece ter sido a da crioula forra Clara Francisca, mulher de Silvério Soares de Pinho, que estava preso na cadeia, ambos considerados muito pobres:

Aos vinte e seis de agosto de mil setecentos e noventa e cinco faleceu com todos os sacramentos, Clara Francisca crioula forra mulher de Silvério Soares de Pinho preso na Cadeia desta cidade muito pobres, foi encomendada e sepultada na Arquiconfraria dos Pardos de que fiz este assento. $^{162}$

Uma das características importantes dos óbitos de pobres é a indicação de que a pessoa era "mendicante”, ou simplesmente considerada como "mendiga”. Dos 18 registros

\footnotetext{
${ }^{157}$ AEAM, Registro de óbito, Livro: Q-10, Data do óbito: 29/09/1768, p. 67.

${ }^{158}$ AEAM, Registro de óbito, Livro: Q-17, Data do óbito: 14/06/1778, p. 6v.

${ }^{159}$ AEAM, Registro de óbito, Livro: Q-10, Data do óbito: 01/05/1782, p. 198.

160 PAIVA, Escravos e libertos nas Minas Gerais, p. 132.

${ }^{161}$ AEAM, Registro de óbito, Livro: Q-16, p. 56v.

${ }^{162}$ AEAM, Registro de óbito, Livro: Q-18, Data do óbito: 22/08/1795, p. 120v.
} 
encontrados que apontavam para essa condição, apenas 4 eram mulheres, havendo uma predominância de homens considerados como mendigos, como consta nos registros de Silvestre, preto forro, que foi sepultado no dia 23 de novembro de 1781, no Rosário, ${ }^{163}$ ou de Bento, preto forro, morador do Pinheiro, pobre mendicante que tinha sido escravo de Francisco da Silva. ${ }^{164}$ Entre as mulheres, encontramos Domingas de Pontes, preta forra, moradora no Rosário Velho, mendicante, que foi "posta de noite dentro da Sé e não se soube quem a tinha posto”165 e Maria, preta forra mendiga também sepultada no Rosário em 1787. ${ }^{166}$ Alguns registros de forros pobres apresentam essa condição. Apesar de reduzido, houve predominância do número de homens mendicantes corroborando com a afirmação de Maria Beatriz Nizza da Silva, sobre a maior assistência conferida às mulheres pobres.

Uma tendência nos óbitos de pobres é a indicação de que os corpos eram deixados nas portas das igrejas. Isso provavelmente era feito por conhecidos dos falecidos que não tinham como pagar as despesas com o sepultamento. Por falta de mais informações dos registros, não podemos concluir se esses sujeitos estavam incluídos nas condições exigidas pela Câmara que os permitisse esmolar.

Mesmo que os libertos conseguissem se estabelecer na sociedade, ou ainda adquirir status, parte deles parecia estar predestinada a acabar na pobreza ou a viver próximo a essa condição. Alguns registros, encontrados sobre os pobres, não indicam a condição de forro, porém havia a indicação de serem “pretos” ou "pardos”, o que demonstra que, mesmo que nunca tivessem vivenciado a experiência do cativeiro, descendiam de indivíduos que haviam sido escravizados. ${ }^{167}$

Grande parte das pesquisas sobre os libertos de Minas Gerais aborda características desses indivíduos por meio das informações encontradas em certas fontes documentais, como os testamentos ou inventários post-mortem. Entretanto, esses registros nos limitam a uma determinada parcela da sociedade, que, certamente, possuía bens e queria garantir sua distribuição com os herdeiros, ou simplesmente queria garantir as condições do seu sepultamento. Caso investigássemos somente os testamentos e inventários post-mortem, ficaríamos restritos apenas a uma parcela dessa população e seríamos privados de verificar as características daquelas pessoas menos abastadas, que por esse meio não foram registradas.

\footnotetext{
163 AEAM, Registro de óbito, Livro: Q-17, p. 48.

${ }^{164}$ AEAM, Registro de óbito, Livro: Q-16, p. 43.

${ }^{165}$ AEAM, Registro de óbito, Livro: Q-14, p. 83.

${ }^{166}$ AEAM, Registro de óbito, Livro: Q-17, p.105v.

${ }^{167}$ FARIA, Sheila de Castro. A colônia em movimento, p.103.
} 
O trabalho com os registros de óbitos nos possibilitou perceber características da dinâmica da população forra existente em Mariana na segunda metade do século XVIII. Muitos registros nos trazem informações que podem servir como indício de pobreza ou de ascensão econômica. Como vimos, não se trata de definir "status social", mas sim de investigar marcas que sugerem as diversas trajetórias dos forros após o cativeiro. É a partir desse prisma que a análise prossegue, destacando registros que nos possibilitam conhecer fragmentos da trajetória de vida dessas pessoas alforriadas.

Ao verificarmos que houve um considerável número de libertos falecendo em condição de pobreza, estamos cientes de que essa situação não necessariamante permeou todas as circunstâncias da sua vida. A trajetória de um sujeito poderia ser marcada por muitos caminhos que o conduziria a tal condição. Mesmo aquele que possuía bens ou uma ocupação que lhe garantisse o sustento, não estaria isento de terminar sua vida nessa situação. Vários motivos poderiam levar uma pessoa à pobreza, como o acometimento de uma doença ou deficiência física, mas acima de tudo limitações financeiras a partir de endividamentos. 


\section{CAPÍTULO 3}

\section{Endividamento dos libertos na Mariana colonial}

Adquirir a liberdade certamente foi um desejo de todos os africanos e crioulos escravizados. Para os brancos, a liberdade pode ter sido sinônimo de não trabalho, mas para os libertos isto se processou de maneira diferenciada. Sobreviver em uma sociedade escravista indicava, sobretudo, ter um trabalho, um ofício que permitisse angariar recursos para a própria manutenção. O principal caminho para adquirir uma ocupação talvez fosse apreender técnicas de alguma atividade especializada, mas isto apenas não bastava. Para se compreender a inserção social desses sujeitos, é importante, antes de tudo, lembrar das redes de solidariedades por eles criadas. Estabelecer vínculos pessoais e até mesmo hierárquicos foi o que permitiu a muitos, no começo de uma nova condição social, o acesso aos artifícios que possibilitassem ocupar um lugar na sociedade.

A dinâmica econômica desses libertos mostrou-se presente na sociedade colonial marianense na segunda metade do século XVIII. Adquirir posses foi uma realidade por eles vivenciada, pois estiveram envolvidos nos mais diferenciados ajustes comerciais. Mas o acesso a bens acabou gerando o endividamento, que, por sua vez, ocasionou conflitos cotidianos que não raro acabaram sendo resolvidos nas instâncias judiciais.

\subsection{Ações cíveis: uma fonte}

O exercício da justiça na América Portuguesa era atrelado às instituições que cuidavam da administração colonial, e apresentava as mesmas cadeias hierárquicas dos demais níveis vigentes de poder. Podia ser compreendida por dois tipos: a justiça concedida e a diretamente exercida. ${ }^{1}$

A justiça concedida se caracterizava pela delegação direta de poderes aos donatários das capitanias na colônia, por meio de cartas de doação e forais, que abrangiam as áreas cível

\footnotetext{
${ }^{1}$ WEHLING, Arno; WEHLING, Maria José. Direito e Justiça no Brasil Colonial: O Tribunal da Relação do Rio de Janeiro (1751-1808). Rio de Janeiro: Renovar, 2004, p. 37.
} 
e criminal. ${ }^{2}$ A justiça real diretamente exercida compreendia as mesmas áreas da justiça concedida, porém possuía uma completa rede que caracterizava as instâncias, sob as quais faziam parte “os tribunais da relação, ouvidores e juízes de fora”. Essas instâncias cuidavam tanto de questões administrativas como judiciais e se diferenciavam pelo poder de atuação, que poderia ser regional ou local. A justiça colonial exercida buscava se adequar à realidade condizente com a população da América Portuguesa, muito embora seguisse os matizes da legislação aplicada na metrópole, recorrendo por diversas vezes ao Conselho Ultramarino. ${ }^{3}$ É, portanto, sobre o segundo tipo que vamos nos deter a seguir.

Na colônia, os tribunais da Relação eram os órgãos superiores localizados primeiramente na Bahia e Rio de Janeiro, cujas atribuições judiciais se referiam, em sua maior parte, em julgar os recursos, agravos ou apelações procedidas de instâncias inferiores, quando da insatisfação de uma das partes interessadas no processo. As Relações se pautavam pelas “Ordenações Filipinas, pelo regimento da Casa de Suplicação e pelos próprios regimentos, além de leis extravagantes, cartas régias, assentos e outros instrumentos que determinavam aspectos específicos". ${ }^{4}$

Os agravos e apelações das Câmaras de Vila Rica e Ribeirão do Carmo foram encaminhados à Relação da Bahia até o ano de 1751, quando se deu a instalação do Tribunal do Rio de Janeiro. Os vereadores dessas vilas expuseram, desde 1730, os problemas enfrentados com a Relação da Bahia, no que se referiam à demora das decisões, extravio dos autos, elevação dos custos e desistência das partes interessadas, o que acabava inviabilizando a prática da justiça. ${ }^{5}$ As relações exerceram ainda funções político-administrativas, além de fornecerem subsídios a governadores e vice-reis.

O poder da ouvidoria se limitava à esfera das comarcas, e era exercido pela figura do ouvidor, que atuava por três anos depois da nomeação concedida pelo monarca. ${ }^{6}$ Os ouvidores, segundo Marcos Magalhães de Aguiar,

(...) tinham a atribuição de conferir todos os processos julgados, acompanhar a manutenção dos registros de presos e as diligências

\footnotetext{
${ }^{2}$ Esse tipo de concessão equivalia à justiça senhorial difundida entre os países europeus no período medieval, somente abolida em Portugal a partir de 1790. Para Arno Wehling, “os braços mais importantes da justiça concedida, porém, foram a justiça eclesiástica, cuja normatização mais significativa é a das Constituições Primeiras do Acerbispado da Bahia (...)”.WEHLING; WEHLING, Direito e Justiça no Brasil Colonial, p. 40-42. Cf. FAORO, Raimundo. Os Donos do Poder: formação do patronato político brasileiro. $2^{\text {a }}$ Ed., Porto Alegre: Ed. Globo; São Paulo, Ed. da Universidade de São Paulo, 1975, p. 117-118.

${ }^{3}$ WEHLING; WEHLING, Direito e Justiça no Brasil Colonial, p. 32.

${ }^{4}$ WEHLING; WEHLING, Direito e Justiça no Brasil Colonial, p.83.

${ }^{5}$ WEHLING; WEHLING, Direito e Justiça no Brasil Colonial, p.126.

${ }^{6}$ PRADO JÚNIOR, Caio. Formação do Brasil contemporâneo. 13ª ed. São Paulo: Brasiliense, 1973, p. 319.
} 
realizadas para a prisão dos culpados, devassar os desvios cometidos pelos oficiais da justiça, conferir as condições carcerárias, além de julgar certas causas em primeira instância e recursos de causas oferecidas junto aos juízes ordinários e juízes de fora. ${ }^{7}$

A intervenção do ouvidor nos processos de instâncias subalternas ocorria em circunstâncias de solicitação de uma das partes envolvidas na devassa. Os agravos feitos às ouvidorias geralmente se davam por insatisfação da sentença proferida por um juiz de uma instância inferior, ou quando esses rejeitavam alguma ação. Também foram comuns as intervenções em casos de falhas graves na condução de processos, como atrasos e ausência de pronúncias. As decisões tomadas pelos ouvidores poderiam alterar por completo a primeira deliberação de uma ação judicial. Esses isentavam os acusados das culpas, ou até mesmo anulavam processos. As anulações geralmente ocorriam em casos considerados como improcedentes, cujas provas pareciam insuficientes, ou simplesmente nos casos de equívocos por parte dos oficiais da justiça. ${ }^{8}$

As comarcas eram divididas em termos. O Termo de Mariana pertencia à Comarca de Vila Rica, local por onde passavam as apelações ou agravos, quando da falta ou problemas na resolução da instância local. Mas parte das ações parecia se resolver na esfera municipal, muito embora “a própria legislação maior previa as formalidades do processo, inclusive as possibilidades de recurso a outras instâncias”. 9 .

O Senado da Câmara representava o poder local e exercia funções judiciais, executivas e legislativas, simultaneamente. As leis municipais se pautavam nas Ordenações Filipinas, na legislação extravagante, além do "direito comum, o costume e a jurisprudência”. ${ }^{10}$ Sua aplicação se dava em casos de conflitos de natureza cível envolvendo “família, sucessões, propriedade e obrigações contratuais”, e de natureza criminal, também das práticas fiscais, políticas e administrativas, sob as quais se incluía a supervisão da ação de vereadores e demais funcionários oficiais, que deveriam assegurar a manutenção da boa ordem local. Os executores da justiça municipal eram basicamente os juízes de fora, magistrados nomeados pela Coroa, e os juízes ordinários, elegidos anualmente nas câmaras municipais, afora o procurador e demais subordinados.

Os juízes de fora e ordinário tinham competência de jurisdição criminal e cível, mas suas atribuições se distinguiam no que se referia aos julgamentos de suas sentenças. Enquanto

\footnotetext{
${ }^{7}$ AGUIAR, Marcos Magalhães. Negras Minas Gerais: uma história da diáspora africana no Brasil colonial. Tese de Doutorado em História Social, FFLCH/USP, São Paulo, 1999, p. 54.

${ }^{8}$ AGUIAR, Negras Minas Gerais, p.57-58.

${ }^{9}$ WEHLING; WEHLING, Direito e Justiça no Brasil Colonial, p.44.

${ }^{10}$ WEHLING; WEHLING, Direito e Justiça no Brasil Colonial, p. 44.
} 
o juiz ordinário sentenciava na Câmara Municipal, com a participação dos demais vereadores, o juiz de fora sentenciava sempre de forma independente. ${ }^{11}$

A qualificação dos juízes ordinários foi uma preocupação constante para as câmaras municipais, que recorriam frequentemente às contratações de assessores como forma de amenizar os problemas gerados pela falta de atributos desses homens para o exercício dos julgamentos. Assim se torna mais evidente a intervenção das instâncias superiores como forma de amenizar as disparidades das sentenças. Aguiar sugeriu que, "quanto maior a gradação do magistrado, maior o rigor na atividade de julgar”. ${ }^{12}$ Mas, no decorrer do século XVIII, essa situação parece ter sido sanada com a freqüência de juízes eleitos que apresentavam formação jurídica. ${ }^{13}$

Em um primeiro momento, no período da criação da vila em 1711 até sua elevação à categoria de Leal Cidade de Mariana em 1745, a estrutura do Senado da Câmara, e, conseqüentemente, do poder judiciário, apresentou-se de forma simplificada. ${ }^{14}$ Suas atribuições englobavam os encargos de natureza econômica, judiciária, política e fiscal. A partir de 1746, essa estrutura recebeu outros postos condizentes com as necessidades da região em constante expansão, como os de natureza territorial e assistencial. ${ }^{15}$ Mas em se tratando exclusivamente da questão judicial, Mariana pode ser considerada como uma região de destaque, pois, nas palavras de Aguiar,

Entre as vilas mineiras, durante boa parte do período colonial, apenas Mariana contou com o magistrado indicado pela coroa para administração da justiça em primeira instância, o juiz de fora. Nas demais vilas, o exercício da função cabia a juízes ordinários eleitos. ${ }^{16}$

Outra questão que influenciou o desempenho da justiça colonial foi o acúmulo de atribuições dos oficiais, que variou de acordo com a extensão da região de vinculação.

\footnotetext{
${ }^{11}$ WEHLING; WEHLING, Direito e Justiça no Brasil Colonial, p. 73.

12 AGUIAR, Negras Minas Gerais, p. 66.

${ }^{13}$ AGUIAR, Negras Minas Gerais, p.53.

${ }^{14}$ Para maiores informações sobre o Senado e a estrutura de funcionamento do poder judiciário em Mariana, ver: VENÂNCIO, Renato Pinto. “Estrutura do Senado da Câmara”. Termo de Mariana: história e documentação. Mariana: Imprensa Universitária da UFOP, 1998, p. 139-141.

${ }^{15}$ Conseqüência dessa expansão foi o surgimento de vários problemas que assolavam as autoridades locais, como o comércio ilícito de escravos, de gêneros alimentícios e mercadorias em geral. Os calhambolas e negros fugidos que permaneciam nos arrabaldes das vilas e cidades também ameaçavam a segurança da população e dos viajantes nas estradas. A justiça punia os crimes cometidos por meio de multas, castigos, exílio, galés; e, em se tratando de escravos acusados de fuga, poderiam até mesmo serem marcados a ferros. SCHWARTZ, Stuart B. Burocracia e sociedade no Brasil colonial. São Paulo: Ed. Perspectiva, 1979, p. 197-198. Sobre o castigo de escravos fugidos em Minas Gerais, ver SOUZA, Laura de Mello e. "Tensões sociais em Minas Gerais na segunda metade do século XVIII”. In: Norma e conflito: aspectos da História de Minas no século XVIII. Belo Horizonte: Editora UFMG, 1999, p. 83-110.

16 AGUIAR, Negras Minas Gerais, p.53.
} 
Segundo Arno e Maria José Wehling, “quanto menor e mais incipiente o núcleo populacional, mais mescladas e indiferenciadas revelavam-se suas instituições”. ${ }^{17}$ Mas, em se tratando das freguesias que se distanciavam da autoridade municipal, foi necessária a presença de um juiz de vintena, responsável por manter a ordem e a aplicação das leis no ambiente paroquial. Dentre suas principais funções podemos citar a feitura de testamentos, julgamentos de casos cíveis menores, cobrança de multas e apreensão de criminosos. ${ }^{18}$ Na região de Mariana, que englobava a uma ampla extensão territorial, foram nomeados muitos homens para ocupar esses cargos no período setecentista.

A freqüência das audiências judiciais também variou de acordo com as dimensões da população local. Nas regiões com mais de sessenta mil habitantes, poderiam ocorrer até duas semanais, mas, nas localidades menores, uma por semana era capaz de atender às demandas da comunidade. Não há referências na historiografia sobre os procedimentos completos dessas audiências; ${ }^{19}$ apenas conseguimos perceber, a partir da análise da documentação, como se davam os trâmites de um processo. Nessas ocasiões, os juízes proferiam sentenças de questões de natureza cível ou criminal, geralmente iniciadas em ambiente privado, mas que aí não se resolviam. Recorrer à justiça era uma das formas de garantir os direitos de quem se sentisse ofendido ou lesado em determinada situação.

A abertura de um processo cível produzia uma série de comprometimentos de valores éticos, como também a obrigação de arcar com o ônus do poder judiciário. O primeiro contato com a justiça se dava por meio de uma petição entregue aos oficiais em um dia de audiência. Essa petição era registrada pelo escrivão para dar origem ao processo, que também era denominado como devassa. Essas devassas podem ser classificadas como especiais, por tratarem de delitos específicos e determinados; mas havia também as devassas gerais, que se caracterizavam pelo caráter coletivo e produziam uma série de interrogatórios na região. As devassas gerais igualmente eram conhecidas como “janeirinhas”, por serem realizadas geralmente no início do ano. ${ }^{20}$

\footnotetext{
${ }^{17}$ WEHLING; WEHLING, Direito e Justiça no Brasil Colonial, p. 54.

${ }^{18}$ RUSSELL-WOOD, A.J.R.. "O Governo Local na América Portuguesa: um estudo de divergência cultural”. Revista de História, São Paulo, nº109, v.50, 1997, p. 62.

${ }^{19}$ Por meio de atas da Câmara da cidade de São Paulo, Arno Wehling observou as condições em que essas audiências ocorriam na casa de vereação: “(...) o juiz dispunha de mesa, com três palmos e meio de comprido por dois de largura, com degrau para os pés; o escrivão tinha mesa própria. Havia lugar previsto para o meirinho e bancos para os litigantes, testemunhas e assistentes”. WEHLING; WEHLING, Direito e Justiça no Brasil Colonial, p.55. Sobre o acúmulo de funções exercidas pelas autoridades judiciais ver também RUSSELLWOOD, “O Governo Local na América Portuguesa”, p. 48.

${ }^{20}$ Essas definições foram mais específicas para os processos crimes, conforme abordagem de Aguiar, mas também podem ser entendidas para as ações cíveis. AGUIAR, Negras Minas Gerais, p.51.
} 
As devassas especiais eram iniciadas por qualquer pessoa livre ou liberta, e sua conclusão dependia do desempenho das partes envolvidas, e, consequentemente, de seus advogados. Os escravos, quando recorriam à justiça, tinham seus representantes legais, e, quando acusados de algum delito, eram representados por curadores nomeados pela justiça. A importância da justiça no período colonial se dava, sobretudo, na estruturação da vida social, estabelecendo espaços e dando margem de conciliação para os mais diversos setores que compunham a população.

A justiça em Mariana parece ter atuado de maneira determinante nos delitos cíveis no século XVIII, apresentando grande número de ações dessa natureza, principalmente entre os anos de 1750 e 1800. Das 22.976 ações existentes no Arquivo da Casa Setecentista de Mariana $^{21}$, 19.546 se referem aos setecentos, sendo 13.543 correspondentes à segunda metade do século. Ou seja, 85\% dos processos existentes se referem ao século XVIII, tendo a maior parte desses delitos (69\%) ocorrido na segunda metade. Desses processos, interessam-nos, neste capítulo, as ações de cobrança de crédito que envolviam libertos. No próximo capítulo serão analisadas aquelas que impediam a legitimação de um processo de alforria, ou as ocasiões em que levavam libertos a sentirem sua liberdade ameaçada. De maneira geral, essas ações eram denominadas como redução ao cativeiro ou ação de liberdade. No momento, cabe analisar os conflitos cotidianos que envolveram os libertos de Mariana na segunda metade do século XVIII, relacionados às práticas de consumo ou de acesso à propriedade.

\subsection{O consumo e o crédito}

Sabemos que a dinâmica econômica mineradora gerou não somente a sistematização dos fluxos abastecedores, mas também a articulação da produção local. As regiões das Minas Gerais que mais se desenvolveram, contaram desde cedo com "uma rede de abastecimento interna, baseada na agricultura de alimentos, pecuária, engenhos de cana e aguardente e até mesmo na produção de tecidos grosseiros”. ${ }^{22}$

\footnotetext{
21 Esse volume é correspondente aos documentos do $1^{\circ}$ e $2^{\circ}$ Ofício, divisão ainda não explicada pela historiografia, mas que pode ser entendida pelo encaminhamento das devassas a diferentes juízes.

${ }^{22}$ FURTADO, Júnia Ferreira. Homens de Negócio: a interiorização da metrópole e do comércio nas Minas setecentistas. São Paulo: Hucitec, 1999, p.199-200.
} 
Ao tratar de questões relativas ao abastecimento da população dessa região no século XVIII, Mafalda Zemella ${ }^{23}$ ressaltou que não foi apenas o número de habitantes que influenciou o consumo, mas também a qualidade da população que viveu nesse período. Sendo a sociedade marianense diversificada, composta por portugueses e descendentes, sobretudo, por escravos e a crescente população de libertos africanos e crioulos, é certo que o consumo se processou de maneira diferenciada.

Em meados dos setecentos, a cidade de Mariana já apresentava uma dinamização comercial capaz de atender à população local, mesmo diante da crise econômica que a partir desse período começou a se instalar. Enquanto os ricos mineradores despendiam seus lucros com artigos de luxo, a classe servil e os pobres se desdobravam em função de adquirir meios para satisfazerem suas necessidades.

Os ricos deveriam sustentar toda a luxúria vislumbrada em seus pomposos sobrados mobiliados, que conjugavam o conforto com o requinte da decoração. Seus trajes sobressaíam pelos delicados tecidos de seda e linho, adornados com acessórios e jóias em ouro e prata. Para completar toda a distinção, bastava observar a alimentação, geralmente composta por variados artigos importados, que foram se tornando cada vez mais presentes nos mercados da região. $^{24}$

O que provia toda essa riqueza era o poder de negociação. Negociava-se aquilo que se podia pagar, ou seja, aquilo que era condizente com determinada situação. Não obstante as restrições de consumo vivenciadas por grande parte da população, africanos, portugueses, pobres ou ricos, possuíam necessidades comuns como alimentação, vestuário e habitação.

\footnotetext{
${ }^{23}$ ZEMELLA, Mafalda P. O abastecimento da capitania das Minas Gerais no século XVIII. 2aed. São Paulo: Hucitec: Editora da Universidade de São Paulo, 1999, p.172. Para Cláudia Chaves, o consumo nas Minas esteve também associado à sociedade ali instalada. No período de apogeu da mineração houve grande procura por mercadorias produzidas na região como das importadas. A transformação dessa tendência se deu a partir da crise dessa atividade econômica, quando "houve uma retração nas importações, sobretudo nos artigos de luxo, e uma gradativa sustituição dos demais produtos com a produção de similares na própria colônia, beneficiando o desenvolvimento do comércio interno de Minas e das demais capitanias”. CHAVES, Cláudia Maria das Graças. Perfeitos negociantes: mercadores das minas setecentistas. São Paulo: Annablume, 1999, p.40.

${ }^{24}$ Pessoas mais abastadas da Capitania de Minas consumiam produtos "secos" e "molhados" que não eram produzidos na região. Os "secos" eram basicamente "camisas, lenços, ceroulas calções, tecidos de linho, meias, saias, toalhas, chapelaria, brochas de sapateiro, carros de lauguel, pacotes de ferramentas, alavancas, almocafre (pequena enxada de ponta utilizada na mineração), cavalos e escravos". Já os "molhados" eram "vinho tinto, vinho branco, vinagre, guardente do reino, azeite do reino, azeitonas de Elvas (Portugal), azeitonas miúdas, bacalhau, peixe de barril do reino, peixe seco do reino, queijo flamengo, manteiga de Flandres, presunto, biscoito do reino, passas, coco da Bahia, nozes, farinha do reino, gengibre, sabão do reino, pêra seca, chouriço do reino, marmelada de São Paulo, camarões, ovos de tainha, badejo, mero, castanhas piladas, e sal do reino". CHAVES, Perfeitos Negociantes, p.90.
} 
Segundo Mafalda Zemella, podemos classificar para o período colonial, especialmente nas regiões das Minas, três tipos de necessidades: a primeira caracterizada por gêneros essenciais à subsistência, a segunda por utilidades indispensáveis ao trabalho e a terceira por artigos de vestimenta. ${ }^{25}$ Esses eram os elementos fundamentais adquiridos pela população colonial mineira a partir das transações econômicas vigentes, e que definiam ainda a estabilidade econômica das pessoas então inseridas nesse meio.

Uma das formas mais difundidas para a aquisição de bens, fosse de consumo ou não, era o crédito. Sua utilização tornava possível a circulação de mercadorias sem a quitação imediata nas transações comerciais. Sabemos que nas Minas do século XVIII, como também nas demais regiões da América Portuguesa, o ouro, medido em oitavas, era a "moeda” que movia as transações. ${ }^{26}$ A partir de 1725 , para se evitar as fraudes em sua circulação, foram criadas as casas de fundição, quando foi proibida a utilização do ouro em pó e definida a circulação em barras. ${ }^{27}$ Mas diante da dificuldade da acumulação desse metal para formação de uma barra por grande parte da população, a circulação em pó ainda foi tolerada dentro da capitania de origem.

A restrição ao acesso da moeda em circulação pode estar associada à ausência de instituições bancárias, ${ }^{28}$ mas também guarda relações com a sazonalidade das atividades locais; tanto roceiros como mineradores estariam mais aptos a saldar suas dívidas nos momentos em que tinham retorno de sua produção. ${ }^{29}$ Conforme afirmou Mafalda Zemella,

(...) grande parte da população das minas era formada por faiscadores, cada um dos quais extraía, dos córregos e ribeiros, dois, três ou quatro vinténs de ouro por dia. Essa gente miserável, quando encerrava o dia de trabalho, passava pelas vendas para adquirir o necessário ao sustento cotidiano. ${ }^{30}$

\footnotetext{
${ }^{25}$ ZEMELLA, O abastecimento da capitania das Minas Gerais, p.174.

${ }^{26} \mathrm{O}$ valor do ouro sofreu constantes alterações ao longo do século XVIII. As informações são de que a oitava de ouro valeu $1 \$ 500$ réis até 1725 , de 1725 a 1730 passou para $1 \$ 200$, de 1730 a 1732 para $1 \$ 320$, de 1735 a 1751 para $1 \$ 500$ e de 1751 a 1823 para $1 \$ 200$. Dados encontrados por Echwege e reproduzidos na historiografia. ZEMELLA, O abastecimento da capitania das Minas Gerais, p. 144-145.

${ }^{27}$ Segundo Simonsen, o ouro que circulava nas Minas passava por uma inspeção quando era abatida a tributação, pois depois de fundido, "eram essas barras pesadas e, verificado o toque, registravam-se sobre as mesmas o seu grau de finura, o peso, a data de sua confecção, tudo autenticado com as armas reais. Acompanhava cada barra a respectiva guia, sem a qual ela não poderia ser negociada”. SIMONSEN, Roberto C. História Econômica do Brasil. 1500-1820. São Paulo: Companhia Editora Nacional, Coleção Brasiliana, 1969, p. 278.

${ }^{28}$ FURTADO, Homens de negócio, p.122.

${ }^{29}$ SANTOS, Raphael Freitas. "Devo que pagarei”: sociedade, mercado e práticas creditícias na Comarca do Rio das Velhas - 1713-1773. FAFICH/UFMG, Dissertação de Mestrado, 2005, p.180.

${ }^{30}$ SANTOS, “Devo que pagarei”, p. 151.
} 
A liquidez da economia e a sazonalidade das atividades de produção parecem ter influenciado a prática do crédito. $^{31}$ Essa modalidade de negociação foi apontada pela historiografia como artifício basilar da economia colonial e imperial, atingindo os mais diferenciados níveis da população. Em um primeiro momento, as práticas créditícias estiveram associadas ao comércio transatlântico; ${ }^{32}$ no entanto, com a consolidação da economia interna, essa modalidade econômica também foi utilizada por outros segmentos da sociedade. $^{33}$ No contexto geral, o crédito foi adotado pelos fornecedores de mercadorias e pelos consumidores finais, fato que acabou generalizando o endividamento dos diversos setores da sociedade colonial.

A prática creditícia foi utilizada por grandes comerciantes marítimos e terrestres, auxiliando igualmente a dinâmica do comércio em pequena escala. Nas Minas, lançaram mão desse artifício a Fazenda Real, fiando os pagamentos do imposto das "entradas” dos comerciantes de grande porte, os pequenos comerciantes que circulavam "pelos caminhos” da capitania, os mineradores, mas também a população que adquiria grande parte de seu sustento nas vendas das cidades. ${ }^{34}$ Se, por um lado, favoreceu o dinamismo comercial desenvolvido

\footnotetext{
${ }^{31}$ FURTADO, Homens de negócio, p.121; SANTOS, “Devo que pagarei”, p.39.

${ }^{32}$ FRAGOSO, João Luís Ribeiro. Homens de grossa aventura: acumulação e hierarquia na praça mercantil do Rio de Janeiro (1790-1830). Rio de Janeiro: Arquivo Nacional, 1992; FRAGOSO, João Luís Ribeiro; FLORENTINO, Manolo G. O arcaísmo como projeto: mercado atlântico, sociedade agrária e elite mercantil no Rio de Janeiro, c.1790-c.1840. Rio de Janeiro: Diadorim, 1993; SAMPAIO, Antônio Carlos Jucá de. Na encruzilhada do império: hierarquias sociais e conjunturas econômicas no Rio de Janeiro (c.1650 - c.1750). Rio de Janeiro: Arquivo Nacional, 2003; SAMPAIO, Antônio Carlos Jucá de. "Crédito e circulação monetária na colônia: o caso fluminense, 1650-1750”. Anais do V Congresso Brasileiro de História Econômica. Belo Horizonte, ABPHE, 2003.

${ }^{33}$ ZEMELLA, O abastecimento da capitania das Minas Gerais; FURTADO, Homens de negócio, SILVEIRA, Marco Antônio. O universo do indistinto. Estado e sociedade nas Minas Setecentistas (1735-1808). São Paulo: Hucitec, 1997; MARANHO, Milena Fernandes. A opulência relativizada: significados econômicos e sociais dos níveis de vida dos habitantes da região do Planalto de Piratininga 1648-1682; Campinas, Dissertação de Mestrado, 2000; ESPÍRITO SANTO, Cláudia Coimbra do. Economia da palavra: ações de almas nas Minas Setecentistas. São Paulo: FFLCH/USP, Dissertação de Mestrado, 2003; OLIVEIRA, Maria Luiza Ferreira de. Entre a casa e o armazém: relações sociais e experiência da urbanização. São Paulo, 1850-1900. São Paulo: Alameda, 2005; SANTOS, "Devo que pagarei”. Analisando inventários da Comarca de Vila Rica dos anos de 1750 a 1822, Carla Almeida revelou a "constatação de baixos percentuais de moeda, que variaram de um insignificante $0,07 \%$ a um modesto $4,37 \%$, apontam para uma economia com baixa liquidez e pequena circulação monetária. A pequena presença de metais preciosos também confirma essa caracterização. Em uma região onde a extração aurífera fôra a razão de ser de sua ocupação, causa espanto uma escassez tão grande de moeda e metais preciosos em circulação". ALMEIDA, Carla Maria Carvalho de. Homens ricos, homens bons: produção e hierarquização social em Minas Colonial: 1750-1822. Tese de Doutorado, Niterói: UFF, 2001, p.173. ${ }^{34}$ ZEMELLA, O abastecimento da capitania das Minas Gerais, p. 152-161. Segundo Milena Maranho, os créditos dos pagamentos de impostos arrecadados pela Coroa eram cobrados pelos "provedores da Real Fazenda e pelos corregedores", enquanto as dívidas comuns eram cobradas por "juízes de órfãos e juízes ordinários". MARANHO, A opulência relativizada, p. 88.
} 
no interior da Capitanina das Minas, por outro, acabou gerando endividamento a partir de sua má aplicação. ${ }^{35}$

As cadeias de endividamentos criadas a partir da utilização do crédito revelam a intricada reprodução da economia mercantil na colônia, conforme define Raphael Santos:

(...) no cume da pirâmide mercantil estavam aqueles que João Luís Fragoso chamou de "homens de grossa aventura" - sejam eles do Reino, da Inglaterra, ou do Rio de Janeiro - que emprestavam ou adiantavam produtos aos seus comissários, responsáveis por abastecer e/ou fornecer empréstimo para uma casa comercial de alcance regional. Esta, por sua vez, financiava a crédito seus produtos às lojas e vendas, nas quais o proprietário negociava fiado o produto com os consumidores finais. Os lucros obtidos pelos negociantes por grosso eram os maiores, por que se tratava da acumulação do sobretrabalho de uma série de pessoas a ele subordinadas. ${ }^{36}$

É no âmbito das práticas cotidianas que envolviam os libertos de Mariana que pretedemos nos deter nessa análise, haja vista que a utilização do crédito estava ligada à possibilidade de adquirir um bem que não se podia quitar imediatamente, mas ao mesmo tempo revelava o tipo de negociação que uma pessoa se permitia realizar. Se a prática facultou o acesso a bens de consumo, também possibilitou certa abertura a homens e mulheres que vislumbraram a ascensão econômica e social. ${ }^{37}$

O crédito, contudo, não pode ser abordado apenas como uma negociação de cunho comercial. As trocas geradas a partir dessa modalidade revelam não somente aspectos da vida econômica dos envolvidos, mas também definições das suas relações sociais. Em uma sociedade marcada por valores relativos à tradição das relações hieráquicas e assimétricas, como a mineira colonial, “o crédito tinha menos a ver com os negócios e ganhos financeiros do que com um mercado de obrigações sociais e de relações de poder”. ${ }^{38}$ Noutras palavras, sua aplicação apresentava uma conotação social na medida em que se concretizava a partir de uma relação de confiança entre o credor e a pessoa a quem se iria favorecer.

As relações estabelecidas entre pessoas que travavam algum tipo de trato comercial poderiam denotar certa aproximação, como laços sociais ou mesmo familiares, simplesmente

\footnotetext{
${ }^{35}$ Ao tratar das questões referentes ao endividamento, os autores basicamente falam do abuso da utilização do crédito pelos mineradores, que a todo custo procuravam otimizar sua produção, investindo, em grande medida na propriedade escrava. BOXER, Charles. A idade do ouro no Brasil: dores de crescimento de uma sociedade colonial. $3^{\mathrm{a}}$ ed. Rio de Janeiro: Nova Fronteira, 2000; ZEMELLA, O abastecimento da capitania das Minas Gerais; FURTADO, Homens de Negócio; SILVEIRA, O universo do indistinto.

${ }^{36}$ ROCHA, Maria Manoela Ferreira Marques. Crédito privado num contexto urbano. Lisboa, 1770-1830. Florença: Tese de doutorado apresentada ao Departamento de História e Civilização do Instituto Universitário Europeu, 1996, apud SANTOS, "Devo que pagarei”, p.39. FURTADO, Homens de Negócio, p.216.

${ }^{37}$ SANTOS, "Devo que pagarei".

${ }^{38}$ OLIVEIRA, Entre a casa e o armazém, p. 135.
} 
por inexistir qualquer tipo de registro que legitimasse a operação a ser realizada; apenas era empenhada a palavra em função de se efetivar um negócio. ${ }^{39}$ A existência de uma descrição, ainda que se tratasse de documentos privados e de próprio punho, poderia indicar algum distanciamento da relação entre os interessados. Nesse caso, referendava-se uma espécie de contrato, por meio de um bilhete passado e assinado pelo devedor, informando o valor da mercadoria creditada, as condições de pagamento e a possibilidade de cobrança pelo credor ou por quem estivesse em poder do registro, caso não se cumprisse com as determinações especificadas naquele papel. Não obstante, interessa-nos perceber que o custo gerado não era necessariamente financeiro, mas acima de tudo social, prevalecendo a presteza e gratidão entre as partes. ${ }^{40}$ Alguns especialistas consideram essas práticas como manifestações de uma “economia do dom”, uma forma de reforçar os laços clientelares com iguais, garantindo contrapartida de uma pessoa a quem havia favorecido anteriormente, ou simplesmente de ampliação das redes de aliança e dependência, ao beneficiar alguém hierarquicamente diferente. $^{41}$

É certo que, na presença ou não de um documento que comprovasse uma negociação, a justiça acatava a execução de toda e qualquer petição que solicitasse a citação de um suposto devedor. Muitos foram os casos em que essas negociações acabavam gerando processos judiciais por motivo de descumprimento das condições previamente estabelecidas. Não havia restrições quanto ao tipo de negociação, as cobranças estavam previstas nas Ordenações Filipinas e envolviam

(...) todos os contratos, avenças, convenças, pactos, composições, compras, vendas, escambos, permutações, dotes, arras, doações, estipulações, promissões, aforamentos, arrendamentos, empréstimos, encomendas, guardas, depósitos, e quaisquer outros contratos de qualquer natureza e condição que sejam (...... ${ }^{42}$

Os credores eram basicamente "os artesãos, os jornaleiros, os boticários e os produtores de alimentos, que adiantavam seus produtos ou seus serviços a crédito". ${ }^{43} \mathrm{Na}$ cidade de Mariana, percebemos que os principais transtornos comerciais se davam em função

\footnotetext{
${ }^{39}$ FURTADO, “A palavra e a letra”. In: Homens de Negócio, 104-119; SILVEIRA, Marco Antônio. O universo do indistinto, p.87-111; ESPÍRITO SANTO, Economia da palavra; SANTOS, "Devo que pagarei”, p.42-48.

${ }^{40}$ SANTOS, "Devo que pagarei”, p. 146.

${ }^{41}$ MAUSS, Marcel. "Ensaio sobre a dádiva”. In: Sociologia e antropologia. Tradução de Paulo Neves. São Paulo: Cosac \& Naify, 2003, p.187-313. HESPANHA, Antônio Manuel e Xavier, Ângela. "As redes clientelares”. In: MATTOSO, José (Org). História de Portugal; o antigo regime. V4. Lisboa: Editorial Estampa, 1993, p.339-349; FURTADO, Homens de Negócio, p.74-79; SANTOS, Devo que pagarei, p. 107.

${ }^{42}$ ORDENAÇÕES FILIPINAS, ordenações e leis do reino de Portugal recopiladas por mandato d'el Rei D. Felipe, o primeiro, editado por Cândido H. Mendes de Almeida. 5 vol. São Paulo: Edição Saraiva, 1960, p. 651.

${ }^{43}$ SANTOS, Devo que pagarei, 154.
} 
da inadimplência com as vendas, empréstimos de dinheiro ou objetos, prestações e solicitações de serviços, dentre outros, o que denota a importância de se satisfazer um negócio, seja pelas limitações econômicas dos próprios credores, ou pela valorização da honra presente naquela população. ${ }^{44}$

Não havia restrição ainda quanto às mercadorias e seus valores, e nem mesmo no que tange à estratificação social na abertura desse tipo de ação. Segundo Marco Antônio Silveira, não eram somente homens ricos e de patentes que tinham acesso à justiça local: "licenciados e reverendos, gente módica como sapateiros ou pedreiros, vendedores de toucinho e trabalhadores em cortes de carne iam a juízo pedir o que era seu”. ${ }^{45}$ Assim, como as pessoas livres, escravos e libertos também participaram de transações de cunho econômico que envolviam o crédito. ${ }^{46}$

Um processo geralmente seguia certo rigor. Depois entregue uma petição à justiça por parte do credor, o suposto devedor seria informado em sua própria casa sobre o conteúdo da ação, solicitado a comparecer em audiência pública “para jurar em sua alma” se era ou não a pessoa a quem o credor dirigia a quantia pedida na demanda judicial. ${ }^{47}$ Caso o réu não comparecesse para jurar, iria correr o processo "a sua revelia", o que ocasionaria no julgamento em favor desse mesmo autor, ou credor. A condenação decorria desse juramento, pois a legislação previa que,

[...] se esta parte citada por juramento dos Evangelhos negar o que lhe o autor demanda, absolva-o logo o Juiz desta demanda, e condene o autor nas custas, que lhe por causa desta citação fez citar. E se o citado não quiser jurar, e recusar o juramento, e o autor jurar, que o réu lhe é obrigado, em aquilo, que lhe demanda, o Juiz condene o réu por sentença no em que o autor jurar, que o réu lhe é obrigado pagar, pois o réu, em cujo juramento o autor deixava, não quis jurar. ${ }^{48}$

O que cabe ressaltar é a intricada relação entre as atividades econômicas cotidianas e o catolicismo difundido na América Portuguesa. Se jurar em falso significaria a absolvição do

\footnotetext{
${ }^{44}$ SILVEIRA, O universo do indistinto, p. 106.

${ }^{45}$ SILVEIRA, O universo do indistinto, p. 102.

${ }^{46}$ Os estudos sobre o crédito na sociedade colonial associam a compra da alforria pela modalidade da coartação a uma prática creditícia. Além disso, indicava também uma forma de ascensão social. SANTOS, Devo que pagarei, 133-137.

47 Apesar do conteúdo das ações encontradas em Mariana para a segunda metade do século XVIII apresentarem em petição a solicitação de juramento da alma para o reconhecimento de uma dívida, esses processos não receberam a denominação de "ações de alma”, conforme percebemos nos estudos anteriormente citados, para Vila Rica (Marco Antônio Silveira e Cláudia Coimbra) e para Sabará (Raphael Santos). Ainda assim, acreditamos que tratam de ações da mesma natureza, não havendo maiores distinções entre as mesmas.

${ }^{48}$ ORDENAÇÕES FILIPINAS, p. 653.
} 
pagamento da dívida, por outro lado também implicaria o comprometimento da salvação da alma, valor cristão de grande relevo àquela população. ${ }^{49} \mathrm{~A}$ crença no Purgatório como um local onde seriam redimidas as culpas, certamente contribuiu para que devedores levassem a cabo o cumprimento de seus compromissos financeiros, como também impediu a exacerbação das cobranças por parte dos credores. Nas palavras de Rapael Santos, "as práticas creditícias foram tomando forma, tendo a usura como o limite moral para a sua atuação". ${ }^{50}$ Disposições civis e eclesiásticas previam a lícita cobrança de juros para as práticas econômicas executadas por parte daquela população. ${ }^{51}$

Nosso objetivo, ao analisar esse tipo de ação, é compreender o poder de negociação da população egressa do cativeiro e os rearranjos cotidianos que permitiram sua inserção em atividades dessa natureza, o que certamente ajudará a iluminar aspectos fundamentais de suas trajetórias sociais.

\subsection{Despesas com a própria subsistência}

A atuação dos libertos de Mariana se deu em variados tipos de negócios. Se, por um lado, o envolvimento nas demandas judiciais revela certo poder de negociação, por outro também nos mostra que sua participação esteve mais associada à inadimplência ou descumprimento de alguma condição, pois, na maior parte dos casos encontrados, esses sujeitos apareciam como réus ou devedores nas transações. ${ }^{52}$ Isso não significa necessariamente que viviam em situação de pobreza, haja vista que o endividamento era generalizado nas Minas colonial. Conforme afirmou Júnia Furtado, embora muitos mineiros

\footnotetext{
${ }^{49}$ SILVEIRA, O universo do indistinto, p. 103.

${ }^{50}$ SANTOS, "Devo que pagarei”, p. 122.

${ }^{51}$ CONSTITUIÇÕES primeiras do acerbispado da Bahía, feitas e ordenadas pelo ilustríssimo e reverendíssimo senhor Sebastião Monteiro da Vide bispo do dito arcesbispado, e do Conselho de sua magestade, propostas e aceitas em o synodo diocesano que o dito senhor celebrou em 12 de junho do anno 1707. São Paulo: Typografia, 2 de dezembro, 1853, p. 329. Ver ORDENAÇÕES FILIPINAS, Título LXVII, "Dos contratos dos usuários”. ORDENAÇÕES FILIPINAS, Livro IV, "Dos contratos dos usuários”, p. 871-876.

${ }^{52}$ Foram consultadas as ações do $1^{\circ}$ e $2^{\circ}$ ofício, sendo que as do $2^{\circ}$, referentes à segunda metade do século XVIII, foram levantadas a partir do manuseio de 22.976 fichas, quando foram encontrados 642 processos relativos aos libertos, que foram analisados a partir da diferenciação tipológica encontrada. Apesar de não alnalisarmos todas as ações de que dispúnhamos, o levantamento nos possibilitou perceber que, em 93,5\% dos casos, os libertos estiveram envolvidos como devedores ou réus, e apenas em 4,6\% como autores. Os conflitos entre libertos perfazem $1,7 \%$ das ações levantadas, ou seja, nesses pouquíssimos casos tanto autores como réus eram pessoas egressas do cativeiro.
} 
tivessem acesso ao ouro, por se tratar de referência universal de troca, comprava-se tudo fiado. ${ }^{53}$ Entretanto, é de fundamental importância considerar o tipo de mercadoria que gerou a negociação e, posteriormente, aquela ação, pois isto permite perceber em que tipo de transações comerciais esses sujeitos estiveram envolvidos.

Ao que tudo indica, grande parte das dívidas poderiam ser contraídas na aquisição de gêneros essenciais à subsistência, ou materiais de uso cotidiano. O inventário de Ana Maria Gonçalves preta forra nos permite afirmar isso; nas dívidas que se arrolou, lê-se

Declaro que devo a Antônio Pinto dos Santos desta cidade, 72 oitavas de ouro por crédito.

Declaro que devo a Manoel Teixeira Ribeiro de fazenda que lhe comprei, 9 oitavas e 1 cruzado.

Devo a Paulo Rodrigues Ferreira, Boticário desta cidade, o que constará em suas Receitas, que abaterá o que se deve abater.

Devo a Teodózio Soares, 5 oitavas e um cruzado de empréstimo e obras de Alfaiate.

Devo a José da Mota, preto forro, 2 oitavas e meia e 2 vinténs de carne que lhe comprei no seu corte nesta cidade.

Devo a Josefa da Mota, no mesmo corte, três quartos e três vinténs de ouro de carne.

Devo a Francisco preto forro no mesmo corte 4 vinténs de ouro.

Devo a Luíza Rodrigues do Couto, três quartos de ouro de um leitão.

Devo ao Alferes Sebastião Pereira Leite, seis oitavas e quarto de telha que lhe comprei e falta de me dar 22 telhas para esta conta.

Devo a Domingos Pereira Carvalho oitava e meia e três vinténs de gastos de sua venda.

Devo a Custódia crioula lavadeira, duas oitavas e três quartos de várias coisas.

Devo a Custódio Fernandes de Souza um cruzado de ouro de conserto de uma parede de minhas casas.

Devo a Francisco José Gonçalves (sic), seis oitavas e quarto de ouro de fazenda que lhe comprei.

Devo às almas santas seis oitavas que lhe prometi.

Devo o padeiro e outras mais de pão e broas, e quero se lhe pague logo.

Declaro que se dever mais alguma coisa e sendo pena de verdade se lhe pague, menos Manoel Carvalho de Matos, que quer cobrar uma dívida de mim, a qual lhe não devo nada, digo, devo coisa alguma. ${ }^{54}$

\footnotetext{
${ }^{53}$ FURTADO, Homens de Negócio, p.119.

${ }^{54}$ ACSM, Inventário, Códice 18, Auto 523. Dados retirados de cópia do testamento anexada ao inventário.
} 
Muitas das dívidas acabavam gerando demandas judiciais, que eram cobradas pelos próprios credores ou seus testamenteiros, no caso da ocorrência do falecimento do primeiro. As demandas referentes a valores - mesmo que módicos - com a aquisição de gêneros para subsistência como "alimentos, tecidos e calçados" 55 podem ser indícios de limitações econômicas sofridas por parte da população liberta de Mariana. Alguns puderam abastecer suas despensas a partir de práticas creditícias, mas foram citados pela justiça por não conseguirem arcar com as dívidas então contraídas.

Em 29 de março de 1783, Antônio Machado preto forro, morador na freguesia da Piranga, foi citado para comparecer em audiência pública do dia 10 de abril na cidade de Mariana, quando deveria jurar em sua alma se era ou não devedor da quantia de 32 oitavas, três quartos e seis vinténs de ouro, procedidas de mantimentos com que Joaquim Pereira de Sá o assistiu e à sua mulher, em período que necessitavam. Antônio se apresentou e fez o juramento, que consistia em colocar a mão direita em um livro dos “Santos Evangelhos” e jurar pela própria alma sobre o conteúdo da ação. Afirmou ser devedor da quantia pedida, sendo logo condenado a pagar, no período de 24 horas, aquele valor mais seis mil, duzentos e nove réis, quantia então referente aos gastos despendidos com a ação. A justiça determinou ainda que se não pagasse no tempo determinado, poderia ser executado e posteriormente ter alguns bens que possuísse penhorados, para a satisfação do valor em questão. ${ }^{56}$

A falta do pagamento de uma dívida, por mais irrisório que fosse o valor, seria prejudicial ao devedor, caso fosse cobrada em instância judicial. Reconhecido como culpado, o réu teria que pagar não apenas o valor anteriormente negociado, mas ainda a quantia despendida naquela demanda, que eram pagamentos aos oficiais de justiça e gastos com o procurador; com isso, corria o risco de se endividar ainda mais e também de perder parte de seus bens com a execução de uma penhora. ${ }^{57}$ Sem contar que um processo judicial denotaria a possibilidade de tornar-se uma pessoa que não inspirasse “confiança” em novas negociações, fato muito prejudicial a quem estivesse sujeito a garantir parte da sua alimentação por meio do crédito. Dessa forma, estaria abalada a "confiança”, que era um dos principais pilares de sustentação dos negócios firmados verbalmente. ${ }^{58}$

\footnotetext{
${ }^{55}$ CHAVES, Perfeitos Negociantes, p.91.

${ }^{56}$ ACSM, Ação Cível, Códice 453, Auto 41326.

57 Apenas nas cobranças de dívidas comuns é que ocorriam a penhora e leilão dos bens do devedor. MARANHO, Milena. A opulência relativizada, p. 88.

${ }^{58}$ SANTOS, Devo que pagarei, p.42.
} 
Joaquim Pereira de Sá poderia ser um comerciante de gêneros alimentícios, ou simplesmente proveu de alimentos por ele produzidos ou comprados a Antônio Machado e sua esposa, sem que pagamento algum fosse efetuado. Os comerciantes estavam entre os principais credores nas Minas colonial, pois “chegava às suas mãos grande parte do ouro extraído" 59 na região. Parte da população com quem mantinham laços sociais poderia ser favorecida em momentos de necessidade. Também eram os distribuidores de gêneros essenciais à alimentação, como o toucinho, os cereais, a carne, o sal, o açúcar, ${ }^{60}$ muito embora algumas dessas mercadorias nem sempre fossem acessíveis a todas as categorias da população.

Nesse período, já se encontrava estabelecida nas Minas um considerável circuito de gêneros alimentícios produzidos e consumidos pela população como legumes, hortaliças, frutas, grãos, milho, farinha de mandioca, tocinho, dentre outros. ${ }^{61}$ Eram artigos de uso cotidiano, e, portanto, altamente consumidos pela população local, fato que pode ter favorecido a estabilização de seus preços na capitania de Minas na primeira metade do século XVIII, pois somente sofreram alterações mais substantivas a partir de $1808 .^{62}$

Foi uma dívida com toucinhos que gerou a ação em que Maria da Silva preta forra foi condenada em 1758. Mesmo depois da sentença proferida, essa liberta não pagou a João de Azevedo Viana a quantia de seis [sic] oitavas, três quartos e três vinténs de ouro, sendo novamente citada pela justiça no ano de 1764 para que ocorresse a execução da sentença. ${ }^{63}$ Se pensarmos que os valores das mercadorias não tiveram grandes oscilações na segunda metade do século XVIII, é possível considerar que o toucinho era comprado por 2 e 3 vinténs de ouro. A quantia cobrada na ação era superior a 192 vinténs, o que nos leva a pensar que se tratava

\footnotetext{
${ }^{59}$ FURTADO, Homens de Negócio, p.122.

${ }^{60}$ ZEMELLA, O abastecimento da capitania das Minas Gerais, p.174.

${ }^{61}$ Segundo Sônia Magalhães esses gêneros eram basicamente laranjas, bananas, quiabos, couves, ovos, pães, leite, azeite de mamona, farinha de mandioca e de milho, grão-de-bico, cevada, arroz, feijão miúdo e fradinho (p. 71). Mas o consumo básico de alimentos dos internos do Seminário de Nossa Senhora da Boa Morte, foi "o feijão, a farinha de milho, o fubá e o arroz” (p. 89). MAGALHÃES, Sônia Maria de. A mesa de Mariana: produção e consumo de alimentos em Minas Gerais (1750-1850). São Paulo: Anablume/Fapesp, 2004. Ver também CHAVES, Perfeitos Negociantes, p.91-92.

${ }^{62}$ CARRARA, Ângelo Alves. Agricultura e pecuária na Capitania de Minas Gerais, (1674-1807). Doutorado em História. UFRJ, 1997, p. 82. SILVA, Flávio Marcus da. "Estratégias de mercado e abastecimento alimentar em Minas Gerais no século XVIII”. Anais do IX Seminário de Economia Mineira 2000, p.114.
}

${ }^{63}$ ACSM, Ação Cível, Códice 444, Auto 13865. 
de uma dívida acumulada, ou seja, que a mercadoria foi fornecida por um longo período sem a contrapartida do pagamento. ${ }^{64}$

A prática cotidiana de disponibilizar uma mercadoria com a condição de receber depois pode revelar "as conexões e as redes de apoio que aquelas pessoas formaram entre si e com outros agentes da cidade.”65 Mas deixar de cumprir esses compromissos firmados a partir da confiança devotada pelo credor e deixar a cobrança correr a juízo, pode ser um indício de restrição financeira por parte do devedor, principalmente para aqueles que recorriam ao crédito para abastecer suas despensas.

A tolerância ao pagamento da dívida, no entanto, ocorreu nesse caso; passados seis anos em que havia sucedido a condenação, o credor novamente levou sua solicitação à instância jurídica para que a decisão anteriormente proferida fosse mais uma vez acatada pelos meios legais. Não sabemos o motivo que impediu a efetivação do pagamento, mas o acúmulo de dívidas poderia ser prejudicial para as partes envolvidas em um negócio, pois para o devedor indicaria a perda de credibilidade na praça local, impossibilitando futuros negócios, enquanto para o credor, indicaria ônus com o valor acumulado.

A população colonial se endividou com os comerciantes de suas localidades, não somente por se apropriarem dos bens por eles fornecidos, mas ainda pelas possibilidades que esses abriam a empréstimos a partir da maior facilidade que tiveram em deter moeda em suas mãos, sobretudo nas regiões urbanas e mineradoras. A ausência de contrapartida de uma pessoa favorecida, fosse por empréstimo ou por concessão de mercadorias, ocasionaria uma cadeia de endividamentos, principalmente em se tratando de bens que diariamente deveriam ser repostos.

Os comerciantes geralmente possuíam listas que possibilitavam a identificação de seus devedores, que poderiam ser encontradas em seus estabelecimentos comerciais ou simplesmente faziam parte de um repertório de anotações mantidas em ambiente privado. Muitos desses registros foram citados nos testamentos ou trasladados em inventários, na ocasião do falecimento de credores. ${ }^{66}$ Foi o que permitiu a cobrança e condenação de três libertos, moradores na Piranga, Freguesia da cidade de Mariana, depois da morte do

\footnotetext{
${ }^{64}$ Não sabemos a quantidade de toucinho que gerou a dívida; as informações de que dispomos sobre preços de mercadorias nos permite apenas saber que o toucinho custava entre 2 a 3 vinténs entre março e abril de 1778, em Vila Rica. O valor mencionado na ação é de seis oitavas, três quartos e três vinténs de ouro, que poderia corresponder a mais de 7200 réis. Cada vintém de ouro correspondia, nesse período, a 37,5 réis. CARRARA, Agricultura e pecuária, p. 43. SILVA, "Estratégias de mercado”, p.116.

${ }^{65}$ OLIVEIRA, Entre a casa e o armazém, p. 134.

${ }^{66}$ FURTADO, Homens de Negócio, p.108-109.
} 
comenrciante Antônio Pereira dos Santos, que forneceu fazendas secas aos mesmos a partir da promessa verbal de pagamento.

Uma condenação de 1767 e outras duas de 1769 indicam que o testamenteiro do comerciante, o capitão Manoel Pereira da Silva, a viúva Gertrudes Bernarda Rosa e o tutor da filha menor, Antônio João Bellas, tentaram garantir os pagamentos, que faziam parte da herança do falecido por meio de bilhetes de crédito assinados e reconhecidos pelos devedores. Isso nos permite perceber que não se tratava mais da relação direta com o negociador, mas de pessoas por ele escolhidas para interceder, no momento que percebeu que sua morte se aproximava. Se as relações mantidas com os libertos permitiram a garantia de recebimento por meio da confiança na palavra, a partir do envolvimento de terceiros, a garantia se daria com a negociação registrada, mesmo que fosse uma escritura privada.

Josefa Dias forra da Piranga ${ }^{67}$ e Euzébio pardo forro ${ }^{68}$ assinaram seus créditos em 1764, o primeiro no valor de 15 oitavas, três quartos e 5 vinténs de ouro e o segundo no valor de 5 oitavas e 5 vinténs de ouro. Josefa foi condenada em 1767 e Euzébio em 1769. Antônia parda forra ${ }^{69}$ em 1769 por ter jurado ser devedora da quantia de 5 oitavas e um tostão. As fazendas secas podiam ser consideradas como produtos de consumo, por se tratar de matéria prima utilizada na feitura de artigos pertencentes ao vestuário.

O financiamento do consumo também foi viabilizado por meio do crédito em momentos de extrema necessidade, como nos casos de valores despendidos com medicamentos e tratamentos referentes à recuperação da própria saúde ou de parentes. Nessas ocasiões, até mesmo propriedades eram empenhadas para garantir a cura de uma moléstia. Os libertos, assim como outros setores da população marianense colonial, tiveram acesso a essas mercadorias e serviços em situações de emergência, com adiamento do pagamento para uma ocasião posterior.

A venda de remédios e drogas parece ter sido difundida entre os padres na América Portuguesa, que não somente se restringiam a receitá-los à população. ${ }^{70}$ Em 06 de junho de 1783, Maria Jacinta crioula forra foi citada em sua casa na Rua Direita por oficiais de justiça para comparecer na audiência do dia 12 do mesmo mês, para jurar pessoalmente se era ou não

\footnotetext{
${ }^{67}$ ACSM, Ação Cível, Códice 464, Auto 10292.

${ }^{68}$ ACSM, Ação Cível, Códice 465, Auto 10308.

${ }^{69}$ ACSM, Ação Cível, Códice 468, Auto 10384.

${ }^{70}$ LIMA JÚNIOR, Augusto de. A capitania das Minas Gerais. Belo Horizonte: Editora da Universidade de São Paulo: Livraria Itatiaia Editora, 1978, p.205; ZEMELLA, O abastecimento da capitania das Minas Gerais, p.165
} 
devedora da quantia de duas oitavas e quarto, procedidas de remédios comprados na botica do Padre Alexandre Gomes Carneiro. ${ }^{71}$

Conforme mencionado anteriormente, esses gastos também implicavam despesas com a assistência de um doente. Luiza era moradora em Mariana "entre as casas do Tenente Miguel Martins e de Manoel Gonçalves de Souza”. Na ocasião da moléstia do seu filho Manoel, da qual ficara "entrevado", Luiza ficou devendo ao Cirurgião Mor José Pinto de Souza a quantia de 8 oitavas de ouro por pagamento de seus cuidados. Assim, em audiência de 16 de junho de 1791, a ré foi citada pelo autor para "jurar de sua alma ou vir jurar na do autor se era ou não devedora da quantia declarada”. ${ }^{72}$ Apesar desses processos não trazerem sentença final, é certo que comprovada a dívida pelo autor, ou mesmo sendo jurada pelo réu, a justiça acabaria por condená-lo. Se o acesso ao crédito dependia das relações estabelecidas entre os negociantes, em momento de conflitos a justiça se mostrava sempre favorável ao credor.

Manoel Carneiro Pereira era boticário em Passagem e havia fornecido remédios para a esposa enferma de Miguel Pinto Álvares preto forro. O valor da dívida somava "setenta e [tantas] oitavas de ouro”, mas Miguel e outras pessoas que por ele intercederam, conseguiram diminuir a quantia para "quarenta oitavas de ouro, ficando o mais excesso de rebate". Segundo Manoel Pereira, foram oferecidas "umas casas"73 para assegurarem o pagamento, caso não fosse feito no termo de dois anos. Essa condição se encontrava declarada em um documento assinado por Miguel e sua filha Luiza Pinta crioula forra. Mas, ao serem citados pela justiça, os réus negaram os fatos apresentados por meio do procurador que cuidou de defendê-los, e que ainda jurou de calúnia a matéria apresentada pelo autor naquela ação. ${ }^{74}$

Luiza afirmava ter sido induzida quando assinou o documento, pois as casas jamais poderiam servir de pagamento de uma dívida contraída por seu pai, uma vez que pertenciam somente a ela. Acusava Manoel Pereira de armar um enredo para enganá-la, dizendo que, em certa ocasião, fora chamada à casa do Guarda Mor Manoel Coelho, “onde se achava o autor e

\footnotetext{
${ }^{71}$ ACSM, Ação Cível, Códice 553, Auto 20290 .

${ }^{72}$ ACSM, Ação Cível, Códice 528, Auto 18720.

${ }^{73}$ Sheila de Castro Faria já fez uma ressalva sobre a utilização do termo “casas de morada” sempre no plural. Para essa autora, o termo representaria não somente o local que ocupado pelo proprietário, mas seria "um complexo de moradia e beneficiamento como também um lugar onde dormiam pessoas diferenciadas”, como possivelmente escravos e agregados. No entanto, sua análise se apresenta mais adequada às regiões rurais. Na documentação analisada, percebemos a utilização do termo para todos os tipos de residência, no entanto, alguns casos apresentam características que diferenciam umas das outras, como "casas térreas”, "casa de sobrado", dentre outros. FARIA, Sheila de Castro. A colônia em movimento: fortuna e família no cotidiano colonial. Rio de Janeiro: Nova Fronteira, 1998, p. 368.

${ }^{74}$ ACSM, Ação Cível, Códice 413, Auto 8995.
} 
seus apaixonados”. Ao se dirigir ao local, passou pela residência de José Gonçalves Pardelhas, onde se achava o Padre Antônio Pinto Álvares, quando solicitou ao mesmo que a acompanhasse naquele momento "para que a não enganassem por ser mulher”. Segundo seu procurador, logo “chegando à casa do dito Guarda Mor, lá fabricaram a obrigação (...), que onde fizeram assinar até, sem que esta soubesse o que assinava, nem o dito Padre lhe dizer coisa alguma”. Dizia-se iludida por ser "preta, rústica e ignorante, alheia nos termos de justiça e fácil de ser enganada pela razão de ser preta”. Em contrapartida, o autor do processo, Manoel Pereira, a acusava de ser “liberníssima [sic], astuta e esperta, e em demanda sagaz”.

Luiza se tornou a principal pessoa a responder pelo processo e pela dívida a partir da morte de seu pai. Surpreendentemente, depois de várias acusações proferidas contra o autor e “seus apaixonados” e de várias audiências em que os procuradores das partes eram citados para se correr dilação, essa liberta apresentou uma petição anunciando a desistência da ação. Nesse mesmo documento confessou ser verdadeira a quantia pedida pelo autor, prometendo arcar com o valor pedido e com as custas da ação.

É interessante perceber os argumentos utilizados pela ré na tentativa de desmerecer a obrigação assinada. Teriam esses libertos a concepção de serem “rústicos” e “ignorantes” por serem “pretos”, ou esse seria um argumento utilizado pela defesa em função de desmerecer o conteúdo da ação? O fato de ter assumido a dívida remeteria mesmo a veracidade do compromisso, ou teria sido a liberta induzida a assumi-la?

Apesar do desfecho da ação, as perguntas são válidas. O que nos importa ressaltar é uma questão mais prática, como a presença de um parente doente, gerando dívidas e conseqüente empobrecimento das pessoas menos abastadas. A situação apresentada revela claramente a condição de pobreza em que se encontrava a família de libertos envolvida nesse processo. Além de não conseguirem pagar o valor devido no termo de dois anos, a casa empenhada parecia ser o único bem de que dispunham naquela ocasião. Mas as condições econômicas que precederam o momento da ação para essa família, não aparentavam ser mais satisfatórias, pois, apesar de possuírem uma casa, o valor da propriedade equiparava-se a uma quantia módica para um imóvel. Seja como for, a relutância em desmerecer o conteúdo da ação revela a difícil promessa de se desfazer de seu próprio “chão”.

Esses poucos casos encontrados a partir da seleção de uma amostragem mais ampla de ações de cobrança são importantes para demonstrar que os libertos tiveram assistência em momentos de necessidade, com gastos referentes ao cotidiano, como alimentos, tecidos e medicamentos, assim como o restante da população. Isso implica que estavam totalmente 
inseridos na sociedade, na medida em que criavam relações clientelares que pudessem favorecê-los em suas atividades cotidianas.

Não é possível conhecer a realidade finaceira dos libertos envolvidos em ações de cobranças; nem mesmo saber se o rompimento dos contratos firmados com seus credores se deu em função de restrição financeira. Estamos apenas tratando de fatos pontuais que marcaram as trajetórias de vida desses sujeitos. Cabe lembrar que ter uma cobrança dessa natureza em juízo pode ter iniciado um processo de empobrecimento, ou ainda acirrado uma situação já estabelecida. Mas, acima de tudo, a ação colocava em risco a honra, princípio ético imprescindível, sobretudo aos egressos do cativeiro, que buscavam a todo custo um espaço naquela sociedade.

\subsubsection{Despesas com a moradia}

Vimos que para garantir o tratamento de um parente doente em uma família de libertos chegou a envolver o empenho da própria casa. Se o desfecho lhes fosse desfavorável, uma nova preocupação haveria de rondar a vida dessas pessoas, a busca de um local onde pudessem se instalar. O financiamento da moradia também se deu por meio de práticas cotidianas creditícias na sociedade mineira colonial, fossem em função de adquirir um imóvel, ou simplesmente alugar. Mas o compromisso com o pagamento dos aluguéis dos locais ocupados também se mostrou inatingível para alguns dos libertos residentes em Mariana na segunda metade do século XVIII. Essas dívidas foram contraídas no período de ocupação do imóvel, mas por vezes permaneceram em aberto mesmo depois de o inquilino desocupar o local.

Adquirir um imóvel na sociedade mineira colonial tinha conotações sociais e econômicas. No primeiro caso, poderia indicar uma forma de ascender socialmente, na medida em que possuir bens e ostentá-los era um valor inerente aos traços culturais e ideológicos da sociedade mineira setecentista. A conotação econômica também se dava pelo viés da ostentação, pois ter acesso a uma propriedade indicava, acima de tudo, a possibilidade de dispor de valores, ainda que fossem utilizados em função de novos investimentos. 
Para os que possuíam mais de uma propriedade, o aluguel parecia ser uma fonte importante de renda. Isso ocorreu mesmo com alguns libertos. Entre os bens citados em testamentos e inventários, 39 pessoas indicaram possuir até 1 casa, 11 pessoas adquiriram 2 e 3 tiveram mais de 2 propriedades registradas nesses documentos. ${ }^{75}$ Francisca Ferreira Machado crioula forra era moradora em Antônio Pereira e possuía duas casas no Morro Santana. ${ }^{76}$ A moradora de Mariana, Ana da Conceição preta forra, possuía duas moradas de casas “citas no Rosário Velho", ${ }^{77}$ outra, Rosa Maria de Carvalho preta forra era proprietária de 2 casas rústicas em que vivia com seu marido, “umas térreas e outras assoalhadas, citas na Rua dos Monsus". ${ }^{78}$ O casal de forros Antônio Teixeira da Costa e Luiza Ferreira Vale possuía uma estalagem que parece ter sido adequada para garantir fonte de renda para os mesmos. Em 1769, Luiza declarava, em seu testamento que era proprietária de uma "casa que de duas se fez uma”. ${ }^{79}$ Já em 1772, seu marido declarou ser viúvo e possuir "uma morada de casas que serviam de estalagem”. 80

A possibilidade de alforriados viverem de rendas de um imóvel alugado potencializou conflitos com inquilinos igualmente forros que não cumprissem com o compromisso firmado em uma negociação. Em 1769, Manoel Luis pardo forro morava em casa alugada por Felix da Costa Chaves preto forro, mas não estava pagando os aluguéis e nem manifestava a intenção de entregar as chaves. A dívida já somava duas oitavas e quarto de ouro, fato que levou o proprietário a cobrar na justiça o valor determinado no momento da negociação. $^{81}$

A cobrança judicial das quantias relativas aos aluguéis, mesmo que se referissem a valores baixos, pode indicar que a honra e valorização da palavra eram fundamentais nas transações entre credores ou inquilinos. A condenação de Paulo Carneiro crioulo forro em 5 de novembro de 1772 apresenta um dado intrigante. Em janeiro desse mesmo ano, o liberto alugou uma casa de morada de Eleutério Caldeira de Resende, em Antônio Pereira, com o compromisso de pagar pela ocupação do local uma oitava de ouro por mês. Em setembro, o locatário recorreu à justiça para cobrar os aluguéis vencidos até julho, pois apenas havia recebido duas parcelas, faltando ainda quatro oitavas de ouro. Além de não cumprir o compromisso, Paulo “ainda alugou as ditas casas a outras pessoas” sem o consentimento do

\footnotetext{
${ }^{75}$ ACSM, Testamentos e Inventários de libertos.

${ }^{76}$ ACSM, Testamento, Livro 46, 1791.

77 ACSM, Testamento, Livro 41, 1791.

${ }^{78}$ ACSM, Testamento, Livro 69, 1762.

${ }^{79}$ ACSM, Testamento, Livro 55.

${ }^{80}$ ACSM, Testamento, Livro 51.

${ }^{81}$ ACSM, Ação Cível, Códice 364, Auto 9442.
} 
proprietário, sendo logo condenado pela justiça em 5 de novembro de $1772 .^{82}$ Esse liberto já seria condenado somente pela falta de comprometimento com a quitação da quantia pedida pelos aluguéis, mas ter alugado a casa para terceiros pode ter agravado ainda mais a sua situação.

Por falta de manifestação do réu, não sabemos se ele permaneceu morando no local, se afastou ou continuou alugando a terceiros. O fato é que, mesmo com a presença de outras pessoas no imóvel por ele alugado, não repassou a quantia pedida pelo proprietário no momento da negociação. A presença constante de bilhetes anexados a esse tipo de ação pode indicar que essas transações não necessariamente se deram entre pessoas com algum laço social. Nessas situações, o documento escrito e assinado poderia favorecer o credor, caso necessitasse levar a juízo as cobranças dirigidas a um locatário.

O casal Maria Pereira Leite preta forra e Manoel Antunes crioulo forro, também foi cobrado pelo testamenteiro de Rita Antunes, preta forra, Agostinho Pereira Braga, pela quantia de doze oitavas, três quartos e um vintém de ouro procedidos do aluguel de casas da falecida. O testamenteiro, advogado na cidade, estava cuidando da testamentaria de Rita, quando informou ao casal "bocalmente” sobre a dívida em 1795, sendo logo assinado o bilhete de crédito anexado à petição da abertura do processo feita em 21 de junho de 1798 . Não sabemos qual motivo contribuiu para a cobrança tardia do valor. Talvez essa liberta tenha protelado a cobrança por possuir vínculos de solidariedade com o casal. Muitas práticas creditícias se deram em função de ajuda mútua entre as partes envolvidas. ${ }^{83}$ Mas em audiência do dia 13 de julho do mesmo ano o solicitador de causas Tomé Dias Montes apresentou procuração dos réus para confessar a dívida, quando foram condenados pela justiça. ${ }^{84}$

Essas dívidas foram parar na justiça em função da falta de pagamento, mesmo diante de tentativas de recebimento a partir da cobrança verbal. Isso comprova que conflitos gerados em âmbito privado somente se aplainavam diante da interferância das autoridades locais.

A preta forra Eugênia Correia de Crasto ficou devendo apenas resto do aluguel da casa de José Álvares Pinto, segundo bilhete de crédito assinado em 21 de agosto de 1754. O valor correspondia a nove oitavas, três quartos e três vinténs de ouro, mas provavelmente só foram pagos em 1756, depois de ter sido cobrada por meio de ação judicial. Eugênia

\footnotetext{
${ }^{82}$ ACSM, Ação Cível, Códice 425, Auto 12748.

83 SANTOS, “Devo que pagarei”, p. 148-149.

${ }^{84}$ ACSM, Ação Cível, Códice 367, Auto 9585.
} 
confessou a dívida em 19 de janeiro e foi condenada a pagar a quantia pedida e as custas do processo em 21 de janeiro. ${ }^{85}$

As dívidas de valores referentes a despesas com moradia podem revelar traços de dificuldade em manter os gastos com sustento e habitação. Seria mais fácil deixar pendentes as quantias procedidas de aluguéis do que aquelas despendidas com a alimentação. A movimentação das pessoas no âmbito urbano foi favorecida em ciscunstância disso. ${ }^{86}$ Essa dificuldade enfrentada pelos libertos pode justificar o fato de alguns terem falecido em residências alheias, conforme percebido nos registros de óbitos analisados no segundo capítulo. Uma opção era abrir mão de suas casas e passar a viver de favor ou como agregados.

Sabemos que nas zonas rurais a agregação guardou certa relação com a preservação de um espaço adquirido por um sesmeiro ou comprador, que logo via a efetivação da posse a partir da ocupação das adjacências do território por terceiros. ${ }^{87}$ Essa ocupação geralmente se dava por pessoas que tinham ligações de consangüinidade ou de laços de afinidade, mas por vezes também indica o amparo a pessoas necessitadas. Nesse sentido, é possível associar agregados a pobres, uma vez que experimentaram a impossibilidade "de viver temporariamente ou definitivamente de um modo autônomo" 88 Ocupar um terreno com o intuito de produzir bens necessários ao sustento foi uma das estratégias adotadas pelos libertos.

$\mathrm{O}$ acesso à terra foi restrito a muitas pessoas da sociedade colonial ${ }^{89}$, e se tratando de alguém que havia acabado de comprar a carta de alforria, as limitações poderiam ser ainda maiores. A permissão para trabalhar em terras alheias seria um bom começo para um sujeito nessa condição; ganhar a vida com a ajuda de terceiros, contudo, poderia gerar uma situação de controle e submissão.

Antônio Fernandes preto forro, morador da Piranga, parecia ocupar as terras pertencentes a Antônio Lopes sem haver qualquer tipo de negociação com pagamentos

\footnotetext{
${ }^{85}$ ACSM, Ação Cível, Códice 401, Auto 11381.

${ }^{86}$ Ao trabalhar com Rol de Confessados dos anos de 1804 e 1809, Ida Lewkowicz percebeu certa mobilidade entre os moradores da Rua do Pisarrão. Em 1804, 37 casas eram ocupadas, enquanto que em 1808 esse número passou para 33. A maior movimentação se deu entre as pessoas que alugavam imóveis, pois $16,6 \%$ delas permaneceram no mesmo local, enquanto a permanência de quem morava em casa própria foi de $50 \%$. A população móvel era de pessoas livres que viviam em condições de agregados, e eram basicamente "parentes, pobres, ex-escravos, às vezes mães viúvas”. LEWKOWICZ, Ida. Vida em família: caminhos da igualdade em Minas Gerais (séculos XVIII e XIX). Tese de Doutorado, FFLCH/USP, São Paulo, 1992, p. 76.

${ }^{87}$ FARIA, A colônia em movimento, p. 365.

${ }^{88}$ BACELLAR, Carlos de Almeida Prado. "Agregados em casa, agregados na roça: uma discussão”. In: SILVA, Maria Beatriz Nizza da. (Org.). Sexualidade, família e religião na colonização do Brasil. Lisboa: Livros Horizonte, 2001, p. 187.

${ }_{89}$ BACELLAR, “Agregados em casa, agegados na roça”, p. 196.
} 
referentes à sua instalação. Mas, em fins de 1790, o proprietário manifestou a intenção de despejá-lo, recorrendo à justiça em 10 de janeiro de 1791 e exigindo que saísse no prazo de 30 dias, sem receber qualquer valor de "benfeitoria que tinha feito, e nem as faça”.

Esse preto forro vivia como agregado de Antônio Lopes, ou então teve sua permissão para cultivar em seu território gêneros necessários à alimentação. Ficou clara a intenção do proprietário de não querer mais aquele liberto morando em suas dependências, mas o acesso ao local seria permitido para que pudesse "colher as frutas das plantas que tiver plantado quando as tiverem maduras”, carregando-as para fora da propriedade. O réu nada opôs àquela determinação e ainda assinou o termo judicial, em 16 de julho do mesmo ano, que significava estar ciente daquela situação. Ficou a cargo do juiz Antônio dos Santos Ferreira apenas a ordenação do pagamento das custas do processo por parte do autor daquela ação. ${ }^{90}$

Ainda que pudesse colher os alimentos que foram plantados no terreno de Antônio Lopes, a partir daquele momento, Antônio Fernandes, preto forro, passaria despender recursos com a habitação, caso não conseguisse se agregar a outra propriedade para exercer sua profissão. Fatores como esse levariam os libertos a recorrerem a pessoas que os pudesse favorecer, fosse em busca de auxílio ou mesmo empréstimo para um novo investimento.

Os créditos referentes ao aluguel também poderiam ser acompanhados de outras dívidas, como mostra a ação de cobrança de Antônio Carvalho dos Santos contra Antônia da Silva preta forra, moradora na Passagem. Antônio Carvalho era o cobrador, mas essa liberta ficou devendo a José da Cunha Basto a quantia de vinte e uma oitavas e doze vinténs de ouro, sendo dez oitavas referentes ao aluguel e onze oitavas e doze vinténs a empréstimos. ${ }^{91}$

A ajuda a libertos necessitados foi uma prática presente na cidade de Mariana, o que pode ter agravado ainda mais as condições de um sujeito que buscava reverter uma situação de limitação econômica. Nem todos os empréstimos puderam ser saldados, como aconteceu com Rita Maria parda forra. Em momento de necessidade, essa liberta recorreu a Miguel Alves de Mesquita, que emprestou a quantia de sete oitavas de ouro. Essa transação revela a possibilidade de uma relação mais estreita entre Miguel e Rita, pois não foi passado nenhum bilhete de crédito no momento da negociação. Rita foi cobrada várias vezes sem que a dívida fosse quitada, o que determinou sua citação para jurar em audiência se era ou não devedora da quantia pedida pelo autor. $^{92}$ Pessoas que tinham a intenção de ajudar acabavam recorrendo à

\footnotetext{
${ }^{90}$ ACSM, Ação Cível, Códice 385, Auto 10447.

${ }^{91}$ ACSM, Ação Cível, Códice 442, Auto 13712.

92 ACSM, Processo sem desfecho. Ação Cível, Códice 362, Auto 9285.
} 
justiça por se sentirem lesadas por aqueles a quem um dia haviam auxiliado em momento de necessidade.

Em janeiro de 1781, João mulato forro, que era oficial de ferrador, se viu obrigado a mudar dos “chãos” que ocupava com seu trabalho, por pertencerem ao Reverendo Padre Francisco Correia, que os queria tapar. Por intermédio de João José Correia, "beneplácito” padrasto de Mariana Francisca Baracho, foi concedida a "graça” ao mulato de colocar seu banco de ferrador em “uns chãos da rua da Olaria”, pertencentes à mesma Mariana, até que encontrasse outro local para se acomodar. ${ }^{93}$ Nessa área se encontravam fincados uns esteios que preparavam o terreno para a construção de uma moradia.

João se instalou naquele lugar, onde fez uma "coberta de telha e debaixo formou a sua tenda, ficando o seu banco e bigorna do ofício em que fazia suas precisas ações”. E ali permaneceu até abril, quando Mariana começou a se incomodar com a demora de sua estadia e com o incômodo que seu ofício causava. Isso justificou a solicitação feita pela proprietária para que o liberto se retirasse daquele local, mas, diante da expressão de pobre e desvalido daquele liberto, Mariana se sentiu comovida e permitiu que ficasse na condição de lhe pagar o aluguel de meia pataca por mês, enquanto não mudasse.

O mulato permaneceu no local sem pagar os aluguéis atrasados até o mês de novembro, quando, em um dia de feriado, aproveitando a ausência da autora e de seu padrasto, desmontou sua tenda e se retirou daqueles chãos. Indignada com a atitude do mulato, Mariana recorreu à justiça para que esse saldasse a dívida que somava uma oitava e três quartos de ouro, procedentes dos aluguéis atrasados. A única parcela quitada foi repassada por Francisco José França, sendo esse valor referente a um serviço que João lhe havia prestado, de umas ferraduras que colocou em seu cavalo. Ainda assim, faltavam uma oitava e quatro vinténs que Mariana pretendia receber.

Em contrapartida, João afirmava dever apenas 1 cruzado de ouro. Dizia ser a quantia pedida pela autora exorbitante com relação ao espaço de terra por ele ocupado, que não passava de dez palmos. Alegava ter começado o aluguel a correr em julho, e não em maio conforme se afirmava. João tentou evitar a ação, quando procurou a autora,

[...] e a esta falou dizendo-lhe que o que devia era meia oitava e quatro vinténs de ouro, porque só estivera cinco meses, e que era o que estava restando, que o recebesse, e mais os quatrocentos réis da diligência do

\footnotetext{
${ }^{93}$ ACSM, Ação Cível, Códice 301, Auto 7255.
} 
oficial e que estava concluída a dívida, e citação para que o queria chamar e não quis a autora receber todo o sobredito, como dirão as testemunhas que o presenciaram. $^{94}$

Mas sua tentativa de pagamento foi em vão; Mariana não quis mais receber o valor das mãos de João, somente o queria em juízo. Isso acabou gerando uma série de conflitos entre as partes, que tentavam à sua maneira desmerecer os argumentos do lado contrário, o que levou à nomeação de testemunhas com o intuito de resolver o impasse em que se encontrava aquela ação. As declarações das testemunhas da autora revelaram que João não só ocupou o lugar para exercer seu trabalho, mas também ali passou a morar, causando grande bulha com o exercício de sua profissão. Reforçaram ainda sobre sua retirada dissimulada do local concedido de boa intenção. ${ }^{95}$ Já as testemunhas do réu insistiram nos argumentos de que o mesmo havia tentado efetuar o pagamento sem que Mariana quisesse receber. ${ }^{96}$

O procurador de João, Manoel da Guerra Leal, acusou Mariana de se apelidar indevidamente de Dona na petição entregue à justiça, uma vez que nem ela, nem seus familiares possuíam qualquer atributo para utilizar tal denominação. Seus argumentos tentaram reforçar o uso indevido desse privilégio, por "ser filha de um Mercador, que vendia fazenda a vara e côvado no Arraial da Piranga, e nem sua mãe nunca se tratou senão por Roza Dias”. Mas em depoimento, Mariana prometia mostrar a razão porque fazia uso e assim podia assinar com Dom.

Muitas foram as tentativas de desmerecimento do depoimento de lado a lado. Mas, em 30 de abril de 1784, a sentença final favoreceu a autora, com base na justificativa de ter sido provado pelas testemunhas da mesma o valor e período que o réu devia de aluguel do lugar ocupado. Quanto à denominação de Dona, a justiça argumentava ser uma pena criminal e, portanto, não adequada à natureza daquela ação.

O procurador do réu acabou embargando a conclusão, o que adiou ainda mais o encerramento da ação. O principal fato que merece destaque foi a argumentação de que o estigma da escravidão por parte do réu havia sido determinante na satisfação da autora. Era a

\footnotetext{
${ }^{94}$ Artigo 4 de contrariedade dos artigos do autor.

${ }^{95}$ Por parte da autora, foram indicados o negociante Francisco José França, Luiz Pinheiro de Souza oficial de entalhador, o oficial de alfaiate, Joaquim dos Santos Miranda crioulo forro e João José Correia da Silva, que era o companheiro da autora.

${ }^{96}$ Em defesa de João falaram à justiça o presbítero secular João Batista Soares, o oficial de sapateiro Manoel dos Santos Silva pardo forro, o corretor do cartório da Câmara Manoel Pereira de Sales, o oficial de carpinteiro Antônio José da Silva, o negociante de venda de molhados Jerônimo Gonçalves pardo forro, Luiz Correa da Silva, que vivia de sua chácara nos subúrbios da cidade, Paula Ribeira de Andrade parda forra que vivia de fazer rendas e Antônio de Souza Ferreira, morador da Freguesia de Guarpiranga, que vivia de sua roça.
} 
palavra desacreditada de um ex-escravo em função da argumentação de uma mulher branca e nascida em melhores condições. Assim, fez agravo ao Ouvidor Geral e Corregedor da Comarca, Tomás Antônio Gonzaga, que foi aceito em 30 de abril de 1785, mas não constam mais informações sobre o processo. Nota-se aqui um forte indício de uma relação clientelar, onde uma pessoa recebeu a "graça” de ocupar um espaço alheio, mas que, ao causar trantornos ao doador ou não corresponder às suas espectativas, teve logo sua concessão negada.

Os libertos envolvidos em questões judiciais por falta de pagamento das moradias ocupadas poderiam possuir restrições econômicas que impossibilitaram o cumprimento de suas obrigações. Isso não impediu que encontrassem pessoas que os favorecessem no decorrer de suas vidas. No entanto, muitas dessas relações podem ter se caracterizado por subordinação da parte que era favorecida. Isso fica claro no caso de Antônio Fernandes preto forro e de João mulato forro. Esses libertos pareciam apresentar todos os atributos para cuidar de sua sobrevivência, mas não dispunham de local onde pudessem se estabelecer. João, além de possuir uma profissão, ainda dispunha de objetos para exercê-la, o que talvez indique que esse liberto passou por momentos econômicos mais favoráveis do que aquele apresentado no momento da ação.

\subsubsection{Os instrumentos de trabalho}

Possuir um ofício e conseguir desenvolvê-lo era algo que contribuiria para tirar os libertos do caminho da pobreza. Mas apenas isso não bastava; outras limitações acabariam por restringir suas possibilidades de trabalho. Um exemplo pode ser demonstrado por parte daqueles que não detinham os instrumentos necessários para o exercício da sua profissão.

O ferro era a matéria-prima básica para a fabricação dos instrumentos de trabalho utilizados na mineração, nos ofícios mecânicos e nos serviços ligados à agricultura. Mas, devido aos altos tributos cobrados para sua importação, os valores dos objetos de ferro na América Portuguesa acabavam elevados, ocasionando na restrição do seu acesso a boa parte 
da população. ${ }^{97}$ Mas, diante da utilização do crédito, tornou-se possível adquirir também esse tipo de mercadoria.

Francisco Machado morreu em Mariana ab intestado, deixando entre outros bens que possuía, ferramentas do seu ofício de carapina. Sua herança foi arrecadada pelo Juízo dos Ausentes e depois arrematada por João Dias Batista, quando as ditas ferramentas foram vendidas “fiado" a Antônio da Costa pardo forro, pelo valor de "cinco oitavas de ouro". Depois de receber esses instrumentos, Antônio parece ter se mudado para a Freguesia do Inficionado, onde passou a utilizá-los sem satisfazer o valor porque os “ajustou e comprou”. Dessa forma, foi citado em audiência de 23 de janeiro de 1764 para que assumisse a dívida e efetuasse o pagamento. ${ }^{98}$

O fato dessa e de outras cobranças terem chegado à justiça indicam a relutância dos libertos às investidas de seus credores. A falta de pagamento, nesse caso, pode indicar a ausência de oferta de trabalho para Antônio, ou simplesmente insuficiência de renda. Caso a ausência de pagamento se desse em função disso, é possível concluir que o exercício de um ofício mecânico nem sempre funcionou como uma via para preservar os libertos de limitações econômicas e até mesmo de endividamentos que os conduziam à condição de pobreza. Mas, ainda assim, não podemos inferir que a inadimplência nesses casos estivesse ligada somente a restrições econômicas, pois a valorização da honra era importante em qualquer negociação comercial.

O acesso ao instrumento de trabalho foi possível a Antônio por meio do crédito, que poderia contribuir para sua melhoria de vida, embora a posse definitiva somente se daria a partir do pagamento da dívida contraída.

É importante considerar também que exercer um ofício poderia implicar investimentos na atividade a ser executada. O liberto que não obtivesse meios de adquirir material para o trabalho, deixaria pendente a prestação de serviços, tornando-se passível de

\footnotetext{
${ }^{97}$ Segundo Mafalda Zemella, "Todos os gêneros ao penetrarem nas minas, tinham de pagar taxas de entrada. Essas taxas, em lugar de serem proprocionais ao valor da mercadoria, eram calculadas sobre o peso delas: pagava-se o imposto proporcionalmente às arrobas. Sendo assim, o ferro, que é material pesado, era excessivamente taxado e, por isso, seu custo nas minas atingia cifra correspondente a $300 \%$ da que se pagava no Rio de Janeiro. O ferro era importado da Europa. Os portugueses adquiriam-no dos fornecedores suecos, hamburgueses e biscainhos e faziam-se itermediários entre os colonos e aquelas praças européias. E naturalmente, a mediação era bem remunerada, acrescentando-se ao preço do ferro os lucros dos intermediários, bem como as taxas da várias alfândegas que o produto devia atravessar, até ser posto nas minas". ${ }^{97}$ ZEMELLA, O abastecimento da capitania das Minas Gerais, p. 178-179.
}

${ }^{98}$ ACSM, Ação Cível, Códice 613, Auto 23665. 
freqüentes cobranças, que por vezes também poderiam ocasionar demandas judiciais, prejudiciais à sua honra.

Outros casos, contudo, parecem indicar simplesmente má fé. O liberto Gabriel Ribeiro, oficial de seleiro, acabou sendo citado pela justiça por não prestar o serviço que havia se proposto a fazer. Em certa ocasião, Félix da Costa Chaves, preto forro, o procurou para colocar em sua sela um rabicho que faltava. Parecia um objeto de valor, pois o autor fez questão de descrevê-la como uma "sela com cochim [sic] de couro, peitoral e silhão [sic]". Depois de receber o valor pedido pelo serviço, Gabriel não fez o trabalho, nem mesmo queria devolver o objeto. ${ }^{99}$

Ainda que esse conflito aparentemente represente conotações de cunho econômico, envolvendo a cobrança de um objeto de valor e uma quantia em moeda, não podemos descartar a relação previamente estabelecida entre as pessoas envolvidas. Trata-se do rompimento de um serviço negociado, a princípio baseado na confiança, e posteriormente na tentativa de restituição de um valor material.

As restrições econômicas vivenciadas pelos libertos de Mariana podem ter contribuído para que os mesmos não conseguissem cumprir parte de seus comprimissos firmados. A dependência financeira poderia incitar o acúmulo de dívidas, que, por vezes, os conduziria à condição de pobreza. O endividamento, portanto, pode não ser considerado unicamente como sinônimo de restrição de suas finanças, pois, conforme mencionado anteriormente, os mineiros recorriam às atividades creditícias para adquirir variados artigos, inclusive os de próprio consumo. Mas o peso da cobrança judicial também não pode ser desconsiderado, pois tinha implicações diretas com os valores morais daquela sociedade. Se, por um lado, o crédito favoreceu a sobrevivência e os investimentos em atividades econômicas, feitas pelos libertos e população de maneira geral, por outro também pode ter causando danos ainda maiores com as demandas judiciais a eles dirigidas. Não cumprir com os compromissos firmados poderia representar ainda o rompimento dos laços de solidariedade marcados pelas relações pessoais, essenciais a quem pretendia se estabalecer socialmente.

\footnotetext{
${ }^{99}$ ACSM, Ação Cível, Códice 413, Auto 12079.
} 


\subsection{Outras dimensões para os negócios}

As situações até então abordadas indicam que os libertos estiveram inseridos nas atividades comerciais da Mariana colonial. Ainda que o endividamento fosse corriqueiro, o fato de uma pessoa ser cobrada em instância judicial por dívidas com mercadorias de uso cotidiano, pode sugerir uma situação financeira adversa. Investimentos mais ampliados também poderiam ocorrer em função das práticas creditícias vigentes nas cidades coloniais mineiras.

A abertura a aplicações mais dispendiosas não necessariamente implicavam uma condição econômica mais favorável das pessoas que se lançavam em tais operações, principalmente em se tratando dos egressos do cativeiro. A intenção de adquirir posses poderia servir como artifício de legitimação do status de liberdade e da tentativa de alcance de distinção. Certos valores implícitos à sociedade mineira colonial, sobretudo à urbana, tendiam a estimar a origem de um indivíduo, seus matizes de convívio e suas posses. ${ }^{100}$ Tais valores foram incorporados pelos libertos, que buscavam em seu meio de convívio a inserção social favorável. ${ }^{101}$ Prova disso foram os investimentos que geravam dívidas que se estendiam por longos anos.

Nas disposições testamentárias deixadas por Brás Moreira de Sampaio, em 1772, morador no Morro Santana em Mariana, havia a indicação da venda de todos os seus bens a Maria Alves crioula forra. Esse testador era português e teve certa distinção social e econômica naquela sociedade, que lhe garantiram privilégios ${ }^{102}$ como a obtenção do título de Cavalheiro Professo na Ordem de Cristo e habilitação como Familiar do Santo Ofício em 1771. ${ }^{103} \mathrm{O}$ comércio de escravos lhe proporcionou a aquisição de muitas propriedades, mas, no momento em que se aproximava da morte, parecia apresentar um patrimônio limitado, justificado pela declaração de “terem morrido nessas Minas muita escravatura” que lhe pertenceram. Seus bens somavam 921\$600 réis e foram comprados a crédito pela crioula forra

\footnotetext{
${ }^{100}$ FURTADO, Chica da Silva e o contratador de diamantes, p.236; SANTOS, Devo que pagarei, 57-58.

101 PAIVA, Eduardo França. Escravidão e universo cultural na colônia: Minas Gerais, 1716-1789. Belo Horizonte: Editora UFMG, 2001, p. 28.

102 ALMEIDA, Homens ricos, homens bons, p.81-82.

${ }^{103}$ IANTT, HSO, Brás, mç. 5, doc. 69. Agradeço a gentileza do colega Aldair Carlos Rodrigues, que me cedeu essa informação.
} 
Maria com a condição de efetuar pagamentos de 2 em 2 anos no prazo de 12 anos sem que pudesse ser executada antes desse período. ${ }^{104}$

Esse fato nos chama a atenção, pois o negócio em que se envolveu essa liberta abrangia a compra de todos os bens de um homem branco, que, mesmo apresentando certo declínio econômico, dispunha de posses que somavam quase um conto de réis, valor substantivo para o período em questão. Também nos chama a atenção o extenso período em que se arrastou a dívida, e ainda a condição de ser cobrada pelo testamenteiro do credor somente depois de 12 anos. Não há referência quanto à relação previamente estabelecida entre o credor e a devedora, mas nota-se que essa liberta não deixaria de ser percebida naquela sociedade a partir do momento em que estivesse em posse dos bens comprados de Brás Moreira de Samapaio.

A posse de bens por parte de um liberto ocorreu por meio de herança ou compra, e, nesse último caso, o crédito teve o seu papel. Em se tratando de propriedades que apresentavam valores mais avultados, a tendência era de que os credores fossem pessoas mais abastadas. O endividamento nas Minas, conforme mencionado anteriormente, foi generalizado, em função da utilização do crédito. Os credores poderiam ser vendedores ambulantes, pequenos comerciantes, arrendatários, boticários, prestadores de serviços, ou pessoas de amplo poder aquisitivo como grandes comerciantes e mineradores.

Os estudos que abordam características dessa modalidade comercial destacam a considerável incidência de dívidas ativas na composição da riqueza de parte da população. ${ }^{105}$ Ao analisar os inventários post-mortem das Comarcas de Vila Rica e do Rio das Mortes, em Minas Gerais, entre os anos de 1750 e 1822, Carla Almeida revelou que o percentual ocupado pelas dívidas ativas encontradas nessas fortunas foi de $19,63 \% .{ }^{106}$ Na Comarca de Vila Rica, a rubrica chegou perto de $25 \%$ da composição da riqueza da população daquela região. ${ }^{107}$ Isso implica que, muitas das pessoas que possuíam bens a ponto de serem inventariados tiveram o

\footnotetext{
104 ACSM, Testamento, Livro 51. Não há referências específicas sobre a denominação desses bens, as informações indicam apenas a compra de "todos os bens".

${ }^{105}$ Essa característica é observada a partir dos trabalhos de pesquisadores que se debruçaram sobre os testamentos e inventários post-mortem para entender a dinâmica do crédito e não pela análise de ações judiciais, documentos que já indicam uma situação de conflito entre as partes envolvidas em um negócio. MARANHO, $A$ opulência relativizada; ALMEIDA; Homens ricos, homens bons; SANTOS; "Devo que pagarei"; OLIVEIRA, Entre a casa e o armazém.

${ }^{106}$ ALMEIDA, Homens ricos, homens bons, p.185.

107 Não houve grande variação das dívidas ativas na composição da riqueza nos inventários post-mortem encontrados para a segunda metade do século XVIII na região. Entre os anos de 1750 e 1779 representaram 24,68\%, ao passo que entre 1780 e 1822 representaram 24,18\%. ALMEIDA, Homens ricos, homens bons, p. 172.
} 
crédito como um dos investimentos econômicos para seus negócios. Nas palavras dessa autora,

A grande parcela ocupada pelas dívidas ativas nas fortunas dos mais ricos $(31,99 \%)$ revela que era a atividade prestamista, qualquer que fosse a sua forma (concessão direta de empréstimos, venda de produtos secos e molhados, venda de escravos, fornecimento de víveres para serem comercializados por outros, transações de venda de imóveis, etc.), o investimento mais atrativo para este setor. Estes eram os homens que controlavam o crédito, elemento fundamental para a reprodução das atividades econômicas. ${ }^{108}$

Carla Almeida verificou ainda na análise dos inventários que os maiores credores também eram os mais afortunados ${ }^{109}$ e tinham como prioridades os investimentos em objetos valiosos de uso doméstico e pessoal, que eram "móveis do interior de suas casas, as vestimentas, as colchas, os talheres de latão ou ferro, os pratos quase sempre de latão, algumas vezes de estanho, as louças de “pó-de-pedra”, representavam uma parte considerável dos seus recursos (...)”. ${ }^{110}$ De certa forma, eram essas pessoas que permitiam que os menos afortunados investissem em atividades que contribuiriam para seu crescimento econômico, embora isso não fosse uma regra na sociedade colonial.

A partir da comparação das fortunas dos inventários então analisados pela mesma autora, foi verificado que, entre esses homens considerados mais ricos, nenhum liberto foi encontrado. Já na categoria dos mais pobres, apenas 10,1\% eram procedentes da África, ou tinham algum indício de relações com um passado escravista. Em suas palavras, "muitos eram homens de cor nascidos livres, filhos naturais de pretas forras; alguns ex-escravos que, por diversos caminhos, tiveram condições de escapar do cativeiro; outros eram descendentes de europeus que tiveram pouca sorte nas Minas”. ${ }^{111}$ O índice de pessoas de origem africana encontrado é modesto, além disso, se inseriram na classe que apresentou fortunas mais reduzidas. Dificilmente um liberto alcançaria posses suficientes para se classificar entre as pessoas mais ricas da região.

\footnotetext{
108 ALMEIDA, Homens ricos, homens bons, p. 215.

${ }^{109}$ A autora analisou inventários de moradores nas Comarcas de Vila Rica e Rio das Mostes, adotando faixas limites de fortunas que variavam entre 0 e 200 libras, e patrimônios com valores acima de 2000 libras. ALMEIDA, Homens ricos, homens bons, p. 190.

${ }^{110}$ ALMEIDA, Homens ricos, homens bons, p. 215-216. Raphael Santos verificou para a região do Rio das Velhas, investimentos em objetos pessoais, de uso profissional, escravos, imóveis, animais, dívidas passiva e ativas. As faixas de fortunas dos inventariados pelo autor analisados variou entre 0 e 249\$999 a 50:000\$000. SANTOS, Devo que pagarei, p. 82.

${ }^{111}$ ALMEIDA, Homens ricos, homens bons, p.222.
} 
Sobre as ocupações dos indivíduos mais pobres da Comarca de Vila Rica que, deixaram inventários, Carla Almeida percebeu que, de maneira geral, esses homens

(...) viviam de vender sua força de trabalho ou de seus escravos para outros proprietários. Muitos desenvolviam alguma atividade artesanal, eram sapateiros, carpinteiros, ferreiros e vários tecelões. Havia ainda alguns pequenos "transportadores" de uma ou duas bestas, soldados e faiscadores. ${ }^{112}$

Os investimentos feitos pelos homens da faixa de menores fortunas basicamente se davam em escravos e imóveis. Vários eram proprietários de uma casa apenas e um ou dois escravos. Por vezes, nem chegavam a possuírem escravos, pois suas atividades econômicas acabavam se restringindo ao âmbito familiar. ${ }^{113}$ Muitos dos investimentos desses homens menos afortunados se davam na melhoria das condições de trabalho. Possuir escravo, além de demarcar socialmente a posição do homem livre, também indicava maior rendimento na atividade econômica desenvolvida. Em se tratando dos libertos, apesar de representarem uma parcela pequena entre esses menos afortunados, nota-se que também investiram na mão-deobra escrava.

$\mathrm{Na}$ amostragem das ações de crédito analisadas, percebemos que os libertos de Mariana não estiveram muito presentes nas transações como credores; ainda assim, quando isso ocorria, geralmente eram negócios que envolviam pequenos investimentos ou simplesmente cobranças cotidianas de naturezas diversas. ${ }^{114}$ Nas disposições testamentárias e inventários encontamos algumas referências sobre dívidas e também sobre créditos. As dívidas eram mais comuns, mas os créditos mostraram relativa proprensão a casos de libertação de escravos por meio de alforria onerosa.

As informações dos inventários nos revelam grande oscilção entre as posses desses sujeitos. O maior monte-mor foi o de Mariana da Silva preta forra, moradora no Sumidouro, somando 1:661\$854 réis; ${ }^{115}$ o menor foi o de Justa Maria Gonçalves, também preta forra, moradora em Mariana, que deixou bens no valor de $85 \$ 575$ réis. ${ }^{116}$ Dos 40 registros, 28 eram

\footnotetext{
112 ALMEIDA, Homens ricos, homens bons, p. 217.

113 ALMEIDA, Homens ricos, homens bons, p.222.

${ }^{114}$ Parte das ações cíveis analisadas trata de questões relativas à liberdade, como as ações de redução ao cativeiro e cobranças de alforria, mas as ações mais representativas se referem a cobranças. Esses registros mostram a participação dos libertos em investimentos condizentes com uma série de práticas cotidianas adotadas pela sociedade marianense colonial.

${ }^{115}$ ACSM, Inventário, Códice 122, Auto 2456, 1755.

${ }^{116}$ ACSM, Inventário, Códice 82, Auto 1751, 1790.
} 
mulheres e 12 homens, desses, 11 moradores em Mariana, 9 em Passagem, 5 em Sumidouro, 3 em Catas Altas, 2 em Furquim, e as demais localidades encontradas se referiam a apenas 1 morador. Quanto ao estado civil, 22 eram casados, 15 solteiros, o restante não apresentando informação. É importante ressaltar que 8 libertos possuíam propriedades acima de um conto de réis, mas apenas 2 eram moradores em Mariana, os demais viviam em outros distritos pertencentes à cidade.

Salta aos olhos que, ainda que houvesse grande discrepância nas posses mencionadas, essas duas mulheres libertas apresentaram valores em comum, como o apreço por jóias. Esses objetos portavam diferentes conotações: por um lado, indicavam distinção econômica, por outro serviam como adornos ou amuletos. ${ }^{117}$ Justa Maria era proprietária de "um par de brincos com pedras encarnadas e falsas que custavam 1\$200" réis, possuía também um coração de ouro, de $\$ 600$, um rosário com “Padre Nosso" de ouro, de $1 \$ 800$ e dois fios de contas, que somavam $1 \$ 050$ réis. Suas jóias valiam $4 \$ 650$ réis, mas também possuía roupas de seu uso e de uso doméstico, além de trastes de casa, dentre eles uma colher de prata. Era proprietária também de uma morada de casas térreas cobertas de telha, localizada no Pissarrão, no valor de $60 \$ 000$ réis. Mariana da Silva possuía jóias que somavam $14 \$ 187 \frac{1}{2}$, dentre elas "uma cruz de ouro de filigrama", $3 \$ 237$ 1/2, "um par de brincos de Aljôfares", 5\$950, "um Espírito Santo de ouro", $1 \$ 400$ e “um fio de contas”, 3\$600. Era proprietária de objetos de cobre, estanho, madeira, ferramentas, roupas, escravos, criação, dívidas ativas e de uma morada de casas térreas com seu quintal e bananal, que valiam $150 \$ 000$ réis.

Essas libertas possuíam objetos com valores distintos e certamente padrões de vida distintos, mas basicamente valorizavam a aparência, característica predominante da hierarquizada sociedade colonial mineira. Os inventários mostraram grande propensão a adquirir vestimentas de estilos e tecidos variados, inclusive importados. ${ }^{118}$ Os homens também tendiam a valorizar adornos e vestimentas, estando presentes em seus testamentos e inventários pares de fivelas para sapatos, pares de botões e sobretudo peças de vestuário em bom uso.

A região de Mariana tendia a concentrar um considerável contingente de pessoas que se ocupavam de cargos eclesiásticos ou administrativos e que adotavam práticas cotidianas

117 MÓL, Cláudia Cristina. Mulheres forras: cotidiano e cultura material em Vila Rica (1750-1800). (Dissertação de Mestrado, História) - FAFICH/UFMG, Belo Horizonte, 2002, p. 132.

${ }^{118}$ Cláudia Mól enfatizou a importância que o traje possuía na demarcação social de um sujeito, que buscava distinguir-se da gente oriunda da terra ao compor sua vestimenta com tecidos importados como "sedas, veludos, baetas, tafetás, dentre outros”. MÓL, Mulheres forras, p. 98-99. 
mais sofisticadas, inspiradas em ideais aristocratizantes. ${ }^{119}$ Os egressos do cativeiro tendiam a seguir parte desses valores, na medida em que incorporavam algumas das práticas dessa elite dominante. O patrimônio dos mineiros revela a valorização de bens como escravos, imóveis e dívidas ativas. ${ }^{120}$ Essa tendência fazia com que libertas como Catarina Correia, moradora em Mariana, possuísse escravos, trastes de casa, objetos de ouro, prata, cobre, estanho, e ainda louças da Índia, mesmo com um monte-mor que somava apenas $456 \$ 500$ réis. ${ }^{121}$ É a partir desse enfoque que analisaremos algumas das ações de cobrança nas quais os libertos envolvidos adquiriam alguns desses bens, fosse em busca de melhores condições de vida ou simplesmente de distinção.

\subsubsection{A compra de escravos}

O investimento em escravaria foi marcante na Minas colonial. No início da ocupação e nas décadas do auge da mineração, a aquisição de cativos era absolutamente fundamental para os mineradores, não somente pela atividade em si, mas também pela demanda da legislação. A Lei das Datas Minerais de 1702 assegurava ao explorador que possuísse mais de 12 escravos maiores possibilidades de explorar os veios auríferos descobertos. Segundo Simonsen,

Ao descobridor era assegurada a primeira data; a segunda à Coroa, e uma terceira ainda ao descobridor, sendo as demais repartidas pelos mineradores que tivessem mais de 12 escravos. Todas essas datas seriam de 900 braças quadradas, ou seja, 4.356 metros quadrados. ${ }^{122}$

Se tal legislação contribuiu para ampliar a aplicação em mão-de-obra escrava, a aquisição não parecia de acesso a toda a população. Os preços nos primeiros tempos da mineração eram exorbitantes, mas, a partir da intensificação das importações de africanos, esses valores foram diminuindo até a década de 1730, quando se iniciou uma fase de constante oscilação que perdurou até os anos 1750. A partir desse período, a tendência foi de queda. Um escravo de idade entre 15 e 40 anos, que custava até então cerca de $168 \$ 000$,

\footnotetext{
${ }^{119}$ ALMEIDA, Homens ricos, homens bons, p. 187.

${ }^{120}$ ALMEIDA, Homens ricos, homens bons, p. 174.

${ }^{121}$ ACSM, Inventário, Códice 124, Auto 2505.

122 SIMONSEN, História Econômica do Brasil, p.279.
} 
passou a valer $92 \$ 000$ réis. A crise no mercado de escravos somente terminaria nas primeiras décadas do século XIX. ${ }^{123}$

Segundo dados de Carla Almeida, sabemos que na região de Mariana também houve uma tendência de queda nos preços dos escravos na segunda metade do século, até o ano de 1850. ${ }^{124}$ No entando, encontramos valores bem altos entre as ações que envolviam conflitos no processo de libertação, que variaram de 60 mil réis a 400 mil. ${ }^{125}$ Algumas quantias avultadas levaram coartados a pedir a reavaliação na justiça, principalmente quando tratava de um escravo que não apresentava mais o vigor físico no momento da negociação da alforria.

Manoel Floriano Pinto era coartado e já havia quitado 200 mil réis, dos 300 mil pedidos pelo seu senhor, quando recorreu à justiça para se desonerar do restante do pagamento. Argumentava ser incoerente aquela avaliação por motivo de se encontrar “quebrado da virilha esquerda, falta de ouvir e tendido das cadeiras”. ${ }^{126} \mathrm{O}$ mesmo aconteceu com a parda Francisca Pereira da Conceição, moradora na Barra do Bacalhau, na Piranga, que, depois de passar por um exame feito por avaliadores do juízo, foi constatado que era portadora de uma “obstrução no fígado antiga e nas vias [misaraicas]”. ${ }^{127}$

Esses fatores devem ser destacados, pois não eram somente as flutuações econômicas que definiam o valor de um escravo: havia uma relação direta entre a variação dos preços, o estado de saúde em que se encontrava e a possível valorização daqueles dotados de algum conhecimento profissional. Escravos com algum problema físico ou com idade mais avançada poderiam ter maior acesso à alforria, ou simplesmente ser adquiridos por pessoas menos abastadas. $^{128}$

Ainda que os registros de óbitos tenham demonstrado queda de mortes de escravos pertencentes aos libertos de Mariana na segunda metade do século XVIII, aventamos a possibilidade de que a diminuição do custo tenha potencializado a aquisição por parte da

${ }^{123}$ Cf. BERGAD, Laird W. Escravidão e história econômica: demografia de Minas Gerais, 1720-1888. Tradução de Beatriz Sidou. Bauru, São Paulo: Edusc, 2004, p.246-247.

${ }^{124} \mathrm{O}$ preço médio que Carla Almeida encontrou para os escravos de 20 de 30 anos de idade girou de $101 \$ 214$ a $169 \$ 136$ mil réis entre os anos de 1750 a 1800 , embora tenhamos encontrado valores ainda mais elevados. ALMEIDA, Carla Maria Carvalho de. Alterações nas unidades produtivas mineiras, Mariana - 1750 a 1850. Dissertação de Mestrado, UFF, 1994, 177-178. As libertas de Vila Rica tiveram escravos africanos adultos com valores entre $60 \$ 000$ e $153 \$ 600$, os crioulos de $80 \$ 000$ a $110 \$ 000$. Os mais valorizados eram aqueles classificados como profissionais, barbeiro, lenheiro, roceiro, ferreiro e mineiro. Esses valiam 120\$000, $140 \$ 000$ e 150\$000. MÓL, Mulheres forras, p. 163 a 166.

${ }^{125}$ Nossa média ficou em torno de 205 mil réis.

${ }^{126}$ ACSM, Ação Cível, Códice 337, Auto 7994, 1766.

${ }^{127}$ ACSM, Ação Cível, Códice 396, Auto 11110, 1800.

${ }^{128}$ Os preços dos escravos doentes pertencentes às libertas de Vila Rica foram arrolados por Cláudia Mól a partir das seguintes indicações: Doente - $90 \$ 000$, Doente de gota - 65\$000, Com erisipela - 90\$000, Tem achaques 60\$000. MÓL, Mulheres forras, p. 163-166. 
população. ${ }^{129}$ O acesso a escravos tinha implicações econômicas, mas também sociais. Em princípio, tornar-se “senhor de almas” era uma forma de se distanciar do passado sob cativeiro, quando se legitimava a ascensão social ao se inserir na hierarquização vigente na sociedade colonial mineira escravista. ${ }^{130}$

A posse de um cativo poderia denotar a acumulação de bens ou inversões produtivas. O crédito possibilitou o investimento na escravaria, mas isso indicava a intensificação de custos, pois o dispêndio se daria em função de arcar com as prestações da dívida e com a manutenção do escravo adquirido.

Entre os libertos que deixaram testamentos ou que tiveram suas posses inventariadas, percebemos que parte substantiva era proprietária de escravos. Dos 102 registros levantados, 74 posuíam cativos. ${ }^{131}$ Isso não significa que o restante estivesse impossibilitado de se inserir nessa categoria social, uma vez que esses documentos tratam apenas de um momento específico da vida desses sujeitos, não impedindo, portanto, que já tivessem sido proprietários em períodos precedentes. Essas propriedades eram predominantemente pequenas, mas também há casos de mais de 10 escravos. ${ }^{132}$ Em algumas situações, tratava-se de mães e seus respectivos filhos, conforme aconteceu com a moradora no Rosário, Tereza Tavares preta forra. Essa liberta redigiu seu testamento em 1753 declarando possuir "uma morada de casas cobertas de telha” em que vivia e ainda uma escrava Josefa Mina, mãe das outras crianças escravas mencionadas, que eram Manoel crioulo de dois anos e Vicente cabra de 10 meses. Tereza os deixou coartados, sendo a escrava e o filho cabra em 1 libra de ouro, e o outro filho crioulo em "três coartas de ouro". 133

Os libertos moradores em Freguesias mais distantes do centro urbano, que exerciam ofícios ligados à mineração ou agricultura, pareciam ser aqueles com maior número de

\footnotetext{
${ }^{129}$ A posse de cativos por parte dos libertos não indicava apenas a possibilidade de fazer um empreendimento econômico, o propósito era reforçar o direito à propriedade e garantir status a partir da inserção no conjunto de proprietários de escravos. CASTRO, Hebe Maria Matos de. Das cores do silêncio: Os significados da liberdade no sudeste escravista. Rio de Janeiro: Nova Fronteira, 1998, p. 36.

130 COSTA, Emília Viotti da. Da senzala à colônia. São Paulo: UNESP, 1966, p.268. SOARES, Márcio de Sousa. A remissão do cativeiro: alforrias e liberdades nos Campos dos Goitacazes, c.1750 - c.1830. Doutorado em História, UFF, 2006, p.304.

${ }^{131}$ A soma indicada se deu a partir da consideração dos nomes dos libertos apontados nesses documentos. O número de testamentos inicialmente somava 69, mas acabou aumentando para 92 em função de cópias desses registros anexados aos inventários. Também foram encontrados separadamente os dois tipos de registros para uma mesma pessoa, quando foram subtraídos os homônimos, após a conferência da data e constatação de que se tratava da mesma pessoa.

${ }^{132}$ Nossa intenção não é de fazer uma análise mais detalhada desses casos, mesmo porque teríamos que distinguir esses dois tipos de repertórios documentais, que aqui foram tratados em conjunto. Nossa prioridade é apenas fazer apontamentos sobre a incidência desses libertos no grupo de proprietários de escravos.

${ }^{133}$ ACSM, Testamento, Livro 64, Página 57v.
} 
escravos. Rosa Maria da Conceição, moradora em Sumidouro, faleceu deixando um dos maiores legados encontrados para os libertos da região de Mariana; seu monte-mor somava 1:477\$100. Entre os bens declarados havia várias ferramentas como almocafres, foices, machados, que poderiam indicar os serviços de minerar e de cultivo executado por parte de seus 10 escravos. Entre esses, também havia uma família de escravos, composta pela crioula Domingas do Rio de Janeiro e seus dois filhos, Izabel e João. ${ }^{134}$

No testamento de Antônio Alves da Silva, redigido em 10 de fevereiro de 1756, constavam 11 escravos, mas na ocasião da abertura do seu inventário no ano de 1762, esse número havia diminuído para 8. Seu monte-mor somava o valor de 665\$562 1/2, portanto inferior ao da liberta Rosa, mas ainda assim composto por outros bens como uma casa térrea com quintal em Sumidouro, “casas citas em uma parte chamada Rocinha”, além de trastes de casa e outras ferramentas. ${ }^{135}$

O morador no arraial do Morro Santana, Julião do Couto preto forro, indicava em seu testamento possuir 6 escravos, Francisco Congo de 40 anos, Estevão crioulo de 15, Teodozia crioula com 12, 2 escravos com 4 anos, Benedito e outro crioulinho, e Feliciana, de 6 anos. A partir da descrição dessas idades, acreditamos que Julião provavelmente trabalhava ao lado do seu escravo Francisco no serviço de minerar, pois declarou ainda possuir "vários serviços de minas já lavradas no Morro de Santana na paragem chamada a Lavra Velha, e o onde mais constar". ${ }^{136}$ Dessa forma, é possível considerar que os investimentos em escravaria não se deram com o propósito de intensificar sua produção.

Os homens mais pobres, incluindo os libertos, eventualmente seriam mais cuidadosos com o tratamento dispensado a seus escravos, uma vez que seus lucros futuros poderiam ter relação direta com o desempenho desses sujeitos. A cautela com a compra revela a necessidade de se fazer um bom investimento.

Gonçalo da Silva preto forro e sua mulher Ana Maria da Costa se sentiram lesados na compra do escravo Antônio, nação Angola, moleque ladino que havia lhes custado cinco quartas e três oitavas de ouro. Antônio foi vendido ao casal por Pedro Antônio de Freitas em fins de 1765, permanecendo com os mesmos por um período de oito meses, até que não houvesse mais dúvidas sobre a doença que o acometia e que lhes acarretara tantos prejuízos.

\footnotetext{
${ }^{134}$ ACSM, Inventário, Códice 92, Auto 1987.

135 ACSM, Inventário, Códice 41, Auto 950.

${ }^{136}$ ACSM, Testamento, Livro 54, Página 23v.
} 
Depois de algum tempo em posse do escravo, Gonçalo e Ana perceberam que o moleque tinha o costume de comer terra “por o encontrar várias vezes comendo-a e a deixava pura quando fazia suas operações naturais, o que é público e notório e assim foi visto de várias pessoas”. Antônio nunca se curava por total; por vezes apresentava alguma melhora, mas logo aparecia inchado e impossibilitado de desempenhar suas funções. O casal acreditava que a doença já havia se manifestado enquanto o cativo ainda se encontrava em poder do seu antigo senhor. Por várias vezes o levaram a Pedro Antônio de Freitas com a intenção de devolvê-lo, mas esse sempre se recusava em aceitá-lo.

Por se sentiram enganados, recorreram à justiça para tentar resolver aquela situação que tanto os prejudicava. Suas intenções eram de que Pedro Antônio aceitasse a devolução do escravo doente, ou então fizesse nova avaliação, levando em consideração a doença, para que fosse reduzido o valor anteriormente negociado. ${ }^{137}$

Nos casos em que a compra de um escravo fosse também vinculada ao rendimento de uma atividade econômica, a impossibilidade de trabalho ou falta de desempenho geraria prejuízo a quem tivesse acabado de fazer esse tipo de investimento. Um escravo doente não significaria somente prejuízos nos lucros, mas ainda representaria gastos com os cuidados de que necessitava.

Adquirir um escravo, por vezes, exigiu grande esforço por parte do comprador, o que indica que muitos libertos acabaram labutando ao lado dos seus cativos, não somente com o intuito de obter maiores lucros, mas ainda com o objetivo de quitar as dívidas contraídas com a compra. As despesas com as atividades desenvolvidas, com os próprios escravos e com gastos pessoais deveriam ser condizentes com os lucros obtidos. Caso contrário, o comprador teria dificuldades em manter seus negócios, e, especialmente, em arcar com as dívidas contraídas com a aquisição de seu novo bem.

A compra de um escravo por meio do crédito se assimilava às liberdades reguladas pela coartação. Na aquisição da alforria, havia uma carta de corte que especificava o negócio firmado entre o proprietário e o escravo que iria se libertar, como, por exemplo, o valor da liberdade e as condições de pagamento. Na aquisição de um escravo, o bilhete de crédito é que garantia as determinações do negócio, também referentes ao valor do cativo e ao período determinado para quitação. Em alguns casos, a primeira parcela era debitada no momento da compra, quando se anexava a esse bilhete um recibo referente à prestação. Os pagamentos seguintes também seriam registrados nesse documento.

${ }^{137}$ ACSM, Ação Cível, Códice 382, Auto 10338. 
Nos casos em que os libertos não pagavam as prestações especificadas, o bilhete de crédito era anexado à petição que dava abertura à ação de cobranças por venda do escravo. É importante lembrar que vários fatores podem ter contribuído para que um liberto não conseguisse quitar essas parcelas. Em algumas situações, os acordos de pagamentos se estendiam por anos; talvez devido a isso, poderiam ser comprometidos a partir de alguma instabilidade econômica ocorrida com o comprador. Nesses casos, o credor geralmente exigia a devolução, e ainda os jornais referentes ao período em que o escravo havia permanecido em poder desse comprador.

Em 25 de novembro de 1760, Andreza de Castro Guimarães crioula forra passou um bilhete de crédito ao Tenente Francisco Machado de Magalhães pela compra de uma escrava angola chamada Maria. O valor era de duzentos mil réis, que deveria de ser satisfeito em três pagamentos iguais no período de três anos. Por não saber ler nem escrever, essa liberta rogou a Antônio Pereira Carneiro que escreveu e ainda assinou o registro como testemunha do compromisso firmado entre as partes.

Em 24 de setembro de 1761, Andreza quitou apenas parte do que deveria ser a primeira parcela, o valor de 30 oitavas de ouro. No entanto, para cumprir com as especificações do bilhete, a liberta teria que pagar em torno de 56 oitavas de ouro, o que corresponderia a um terço do valor da dívida. ${ }^{138}$ Acontece que nenhum valor posterior foi repassado a Francisco Machado, que somente recorreu à justiça no ano de 1769, quando a ré foi citada em 25 de fevereiro. ${ }^{139}$ Na audiência do dia 6 de março, Andreza confessou ser verdadeira a quantia pedida naquela ação, sendo logo condenada a pagar o valor pedido e as custas do processo. ${ }^{140}$

Embora o investimento em escravaria não se desse exclusivamente em função de intensificar uma atividade econômica realizada, e que não saibamos qual era a ocupação de Andreza, podemos levantar a hipótese da compra de sua escrava estar associada ao auxílio de afazeres domésticos, ou a outra atividade econômica que desenvolvesse, que poderia ser fiação, tecelagem, costura, produção de alimentos etc. ${ }^{141}$ Alguns trastes de casa descritos nos testamentos ou inventários das libertas da região de Mariana indicam atividades de âmbito doméstico, como a moradora da Passagem, Ângela de Souza Ferreira preta forra, que possuía

\footnotetext{
${ }^{138}$ Em medos de agosto de 1751 até os anos de 1823, a oitava de ouro valia 1.200 réis, o que o valor da dívida referente a 166 mil e 67 oitavas de ouro. As parcelas seriam em torno de 56 oitavas de ouro. ZEMELLA, $O$ abastecimento da capitania das Minas Gerais, p. 144-145 e SIMONSEN, História Econômica do Brasil, p.283.

${ }^{139}$ Na petição entregue à justiça, o autor cobra a quantia de 169 mil e oitocentos e doze réis referentes a "fazendas" que a ré teria comprado em sua loja, mas o bilhete de crédito se refere à compra de uma escrava.

${ }^{140}$ ACSM, Ação Cível, Códice 540, Auto 19481.

${ }^{141}$ LEWKOWICZ, Vida em família, 94.
} 
“fornos de fazer tabaco", ${ }^{142}$ ou então aquelas que possuíam chocolateiras, diversas bacias, pratos e frascos, o que pode revelar a produção de iguarias possivelmente vendidas em suas respectivas freguesias ou nas cidades. ${ }^{143}$

A preferência pela aquisição de mulheres derivou de motivos como a maior versatilidade do trabalho feminino, a tendência de apresentarem menores preços no mercado e a possibilidade de reprodução natural. ${ }^{144}$ No entanto, não podemos afirmar que no caso de Andreza esses fatores tenham prevalecido no momento da escolha, pois a escrava que adquiriu possuía um valor bem expressivo. A inadimplência por parte daquela liberta nos faz pensar em algumas hipóteses. Para firmar um compromisso de pagar parcelas anuais de aproximadamente 67 mil réis, Andreza provavelmente esperava contar com renda superior para arcar com a dívida, mas o fato de não conseguir quitar nem uma parcela integral referente ao preço da escrava, indica que no período de um ano, seus os ganhos não corresponderam às suas expectativas, impedindo que cumprisse com os pagamentos do investimento feito. Uma hipótese alternativa é a de que a aquisição ocorreu simplesmente em função de adquirir status a partir da inserção entre os proprietários de escravos.

A cobrança judicial, por parte do credor, o Tenente Francisco, foi adiada. Apesar de não sabermos quais os motivos levaram à demora, deduzimos que houve tentativas de receber o valor referente ao bem de que se havia desfeito, antes de recorrer aos meios legais. A cobrança poderia ter sido feita logo após o vencimento da terceira e última parcela, no ano de 1763, mas isso só veio a ocorrer em 1769, ou seja, seis anos depois. Esse fato pode ser atribuído ao caráter clientelista do crédito, onde prevalecia o comprometimento de ajuda mútua, fazendo com que o credor esperasse tanto tempo para levar a juízo o seu intento, principalmente pelo fato da quantia pedida ser muito próxima do valor negociado.

Outro caso que apresenta essa característica é o de Josefa da Costa crioula forra, moradora no Morro Santana. Em 18 de fevereiro de 1771, essa liberta comprou do Ajudante Francisco Pereira Freitas um “moleque novo por nome José de nação benguela”, no valor de cento e noventa e dois mil réis, que deveriam ser satisfeitos em pagamentos semestrais, no período de três anos. Ou seja, esse valor corresponderia a 160 oitavas de ouro, sendo cada

\footnotetext{
${ }^{142}$ ACSM, Inventário, 1798, Códice 101, Auto 2105.

143 Moradoras em Mariana, Tereza Maria de Jesus e Ana Maria Gonçalves; Josefa Martins residente na Passagem, dentre outras. Seguem indicações respectivas: ACSM, Inventário, 1790, Códice 122, Auto 2541; ACSM, Inventário, 1766, Códice 18, Auto 523; ACSM, Inventário, Códice 106, Auto 2183.

${ }^{144}$ Intrepretação de Carlos Bacellar recuperada por Márcio Soares. O segundo autor ainda atribuiu a opção por mulheres a outras escolhas, como as possibilidades de acirrarem os conflitos inerentes à escravaria de pequeno porte e da própria relação entre senhores e seus escravos. SOARES, A remissão do cativeiro, p.304. Cf. BACELLAR, Carlos Almeida Prado. “A escravidão miúda em São Paulo colonial”. In: SILVA, Maria Beatriz Nizza da (org.). Brasil: colonização e escravidão. Rio de Janeiro: Nova Fronteira, 1999, p. 243.
} 
prestação referente a pouco mais de 26 oitavas. Os pagamentos começaram a ser efetuados somente em 03 de janeiro de 1774, sendo o último recibo passado em 31 de julho de 1777. Foram dadas sete parcelas, mas nenhuma delas atingiu o valor empregado no bilhete. ${ }^{145}$

Em 15 de janeiro de 1778, Francisco recorreu à justiça para cobrar de Josefa o restante do valor, que somava quarenta mil e treze réis, correspondentes a quase 34 oitavas de ouro. No dia 27, a ré se dirigiu à “casa de morada” do escrivão que cuidava do caso, para reconhecer sua dívida, sendo logo condenada a pagar o valor pedido e custas do auto, que somavam $3 \$ 725$ réis, em audiência pública do dia $28 .{ }^{146}$

Nota-se que Josefa sempre entregou algum valor correspondente ao que deveria ser a parcela. No entanto, não conseguiu seguir à risca as condições determinadas no contrato. Se lhe faltaram meios financeiros de quitar a dívida, o credor também se mostrou tolerante nesse caso, pois somente cinco anos após o vencimento da última prestação recorreu à justiça para receber a quantia que lhe pertencia.

Alguns desses libertos amealhavam quantias que lhes davam acesso à compra de um escravo. Mesmo que não fosse possível quitar todo o valor, o crédito lhes proporcionava a posse imediata desse bem com a condição de seguirem os pagamentos espaçados. Poderiam fechar esses contratos contando com os lucros provenientes do trabalho do escravo adquirido para o pagamento das parcelas, embora nem sempre isso pudesse ocorrer. Afinal, tornar-se proprietário de escravo também era uma forma de legitimar a libertação e se distanciar do passado escravista.

Francisco Alves Coutinho preto forro e sua mulher Dionísia Alves preta forra compraram dois escravos de nação mina do Furriel João Ferreira da Rocha, Antônio e sua mulher Dorotéia, no valor de oitenta e oito oitavas, pagando metade à vista. Ficaram devendo a quantia de quarenta e quatro oitavas, declaradas em bilhete de crédito, em 11 de abril de 1782. Não sabemos qual a relação que o casal de libertos tinha com o casal de escravos, mas podemos inferir que essa compra não se dava somente por motivos de melhoria nos rendimentos dos trabalhos. O valor pedido era reduzido, de 88 oitavas de ouro, que condizem com apenas 105\$600 réis, indicando talvez a possibilidade desses escravos apresentarem idades mais avançadas.

Em junho de 1783 foram dadas mais trinta e duas oitavas, ficando de resto apenas onze oitavas, três quartos e seis vinténs, quantia não saldada e solicitada perante a justiça em

\footnotetext{
${ }^{145}$ Seguem as datas e valores correspondentes aos recibos anexados ao bilhete de crédito: 03/01/1774 = 21 oitavas e meia e i vintém, 15/12/1774 = 20 oitavas, 26/05/1776 = 17 oitavas e 3/4 e 1 tostão, 31/05/1776 = 14 oitavas e 3 vinténs, 21/08/177[6] = 20 oitavas, 04/03/1777 = [13] oitavas, 31/07/1777 = 20 oitavas.

${ }^{146}$ ACSM, Ação Cível, Códice 454, Auto 9850.
} 
24 de maio de 1784. Nesse caso, mesmo estando quase todo o valor quitado, o credor não foi muito tolerante com a inadimplência do casal. Independente da realidade econômica que enfrentavam, haveriam de buscar meios para garantir o pagamento da quantia pedida em ação judicial.

No decorrer do processo aconteceu algo inusitado. Em 25 de maio foi apresentada uma petição em nome do autor, absolvendo os réus da quantia pedida, mas no mesmo dia, o procurador de João Ferreira, Diogo Pereira Ribeiro de Vasconcelos, pediu vista do processo e declarou que seu constituinte não reconhecia aquele documento, afirmando ser o mesmo falso. Esse argumento foi aceito pela justiça, que ordenou que fossem assinados dez dias para os réus “alegarem e provarem os embargos”. Os réus acabaram não se manifestando, o que gerou a sentença do dia em 19 de junho de 1784 :

Condeno ao Réu pague ao Autor onze oitavas e três quartos e seis o de resto do crédito a folha 3 , visto no dez dias, que lhe foram assinados não alegar, nem provar matéria, que da condenação o revela-se e pague mais as custas em que outrossim o condeno.

Manoel da Guerra Leal de Souza e Castro.

Como podemos observar, os réus foram condenados por não haver nenhuma manifestação em defesa do documento de dispensa apresentado à justiça. Além da quantia pedida pelo autor, eles teriam que pagar mais $7 \$ 456$ réis das custas do processo. Não sabemos a origem desse documento, nem mesmo se os próprios libertos o forjaram.

A utilização do bilhete de crédito era uma forma de comprovar a existência de um negócio, embora ainda assim, a pessoa haveria de confirmar perante a justiça se a dívida era verdadeira ou não, ou seja, era necessário "reconhecer o crédito, sinal e obrigação”. A tolerância dos credores em receber os valores referentes às suas dívidas ativas revela características importantes da relação estabelecida com o devedor. O caso desse casal de libertos indica uma estrita relação de negócios em que nenhum deslize haveria de ser perdoado. Acreditamos, porém, que, na utilização do crédito, na maior parte das vezes, a aproximação entre as partes já teria ocorrido. O caso de Domingos Ladeira preto forro revela a possibilidade de pensamentos nesse sentido.

Outro caso é do falecido Capitão Manoel Manso, que deixou o liberto crioulo Domingos Ladeira trabalhar em suas terras minerais, "chamadas da Sociedade Grande de Antônio Pereira”, herdadas por um tio chamado Manoel Rodrigues Coelho. Nesse local só trabalhavam escravos que tinham o consentimento de todos os sócios, mas, com a intenção de favorecer o liberto, o Capitão Manso permitiu sua labuta naquelas paragens. Domingos 
começou a trabalhar "no rabo das Canoas ou nas Catas”, provavelmente no ano de 1769, em companhia de um escravo do Capitão, depois de firmar o aluguel no valor de uma oitava por semana.

Em certa ocasião, Domingos pediu ao Capitão que lhe comprasse um moleque, "pois tendo-o, certamente havia de fazer conveniência, e com muita brevidade lhe pagaria pelo mesmo preço porque o ajustasse e comprasse”. Diante “das choradeiras e grande lábia” e “por ser astucioso”, Manoel Manso ordenou que escolhesse um dos escravos que Antônio José de Castro Leite estava vendendo. Em fevereiro de 1770 foi comprado "um moleque bom, por nome Manoel de nação Benguela”, pelo valor de 125 mil réis. Manoel Manso havia advertido o liberto Domingos, que, na falta de pagamento, tomaria posse do escravo.

Domingos parece não ter cumprido com o trato firmado com seu credor, mas, ainda assim, o escravo não fora tomado, por motivo da sua esposa se encontrar "pejada”. Manoel Manso, com receio de que algo a acontecesse, disse a várias pessoas que aguardaria até que a criança nascesse, para tomar alguma providência quanto àquele fato.

Em fevereiro de 1771, Manoel Manso faleceu, deixando como seu testamenteiro Roque Afonso Monteiro, que, em julho daquele ano, recorreu à justiça para fazer as cobranças das dívidas ativas do falecido. O testamenteiro cobrava duas parcelas do aluguel do escravo, uma no valor de 20 oitavas de ouro, vencida em primeiro de fevereiro de 1770 e outra no valor de 62 oitavas, vencida em julho de 1771. Além disso, também queria receber pela compra do moleque Manoel. Roque Afonso argumentou que, depois da posse do escravo pelo liberto Domingos, esse nunca mais manifestou qualquer tentativa de pagamento da dívida contraída. Ao que tudo indica, Domingos permaneceu trabalhando com os dois escravos, sem cumprir o acordo firmado. O escravo alugado também ficou lhe servindo mesmo depois da morte de seu senhor.

Domingos negou a dívida alegando que se fosse verdadeira, não teria continuado o trabalho com o escravo alugado pelo Capitão Manso e esse tampouco lhe forneceria outro. Argumentou que o falecido é que lhe ficara devendo valores referentes a alguns serviços e viagens feitas a seu pedido. Diante desse impasse, coube à justiça ouvir as testemunhas das partes para tentar esclarecer o caso.

Em dezembro de 1771, se apresentaram as testemunhas do autor, que afirmavam ter Manoel Manso relatado a intenção de cobrar o liberto depois que seu filho nascesse, além de outras informações que desmereciam os argumentos do réu. Talvez por se encontrar em uma situação delicada, e tentando evitar prejuízos ainda maiores, em petição entregue à justiça em 26 de março de 1772, Domingos declarou que, 
(...) na causa de libelo que lhe move Roque Afonso Monteiro, se acham compostos ao suplicante fazer entrega de um escravo por nome Manoel de nação Banguela de que procede $124 \$ 000$ pedidas no libelo, e todas as custas que se contarem dentro do tempo de 3 anos em cinco pagamentos, o que por rata lhe tocar, e quanto ao escravo se lhe já faz entrega ao suplicado [sic].

Essa decisão foi tomada em vista do valor dos depoimentos das testemunhas. ${ }^{147}$

O caso desse liberto nos mostra que seus ganhos estavam totalmente vinculados à ajuda do Capitão Manoel Manso, homem de "boas contas e muito abundante de bens da fortuna”, que, mesmo se sentindo prejudicado, adiou as cobranças em decorrência da gravidez da mulher do liberto. Se fosse um homem com limitações econômicas, isso provavelmente não teria acontecido. Caso o Capitão não tivesse falecido, Domingos talvez pudesse contar com a chance de novas negociações, o que não haveria de acontecer com Roque, que, como testamenteiro, seria implacável em sua cobrança.

O desfecho dessa ação nos parece intrigante. Domingos mostrou a intenção de devolver o escravo e ainda de pagar toda a quantia referente à antiga dívida e à quantia do jornal do escravo alugado. Esse pagamento seria efetuado a partir de nova negociação. Talvez fosse uma tentativa de se manter trabalhando no local concedido por Manoel Manso. O que interessa é que Domingos acabou se desfazendo de um bem que possivelmente lhe traria maiores ganhos no trabalho. Se a opção de entregar o escravo fosse menos onerosa, ainda assim, permaneceu com uma dívida que lhe custaria alguns anos de esforço para quitá-la.

Esse caso nos mostra que a sociedade colonial marianense foi marcada por redes de solidariedade, e que os libertos souberam manejá-las na medida em que criaram laços pessoais com quem poderia favorecê-los. Conforme afirmou Hebe Matos, "um bom 'padrinho' era, na maioria dos casos, um recurso de sobrevivência absolutamente necessário”. ${ }^{148}$ A relação entre Domingos Ladeira e o Capitão Manoel Manso pode ser vista dessa forma, apesar de um desfecho contraproducente. O acesso ao trabalho e à posse de um escravo foi aberto a esse liberto a partir de um vínculo criado com uma pessoa influente.

O crédito abriu aos libertos uma via de acesso à propriedade de escravos, mas, entre os casos analisados, a manutenção da posse não foi possível por um período muito extenso. Isso não significa que a eventualidade de ampliação de seus negócios não fosse possível de se realizar. Alguns se arriscaram em diversificadas atividades comerciais com o intuito acumularem pecúlio que lhes proporcionasse melhoria na qualidade de vida. Os investimentos

\footnotetext{
${ }^{147}$ ACSM, Ação Cível, Códice 304, Auto 7313.

${ }^{148}$ CASTRO, Das cores do silêncio, p. 54.
} 
bem sucedidos nessas atividades implicariam ascensão econômica, experimentada por alguns desses sujeitos.

\subsubsection{Negócios com o gado e com a terra}

Sabemos que as atividades relacionadas à agricultura e à pecuária estiveram presentes em todo o período colonial mineiro. Desde os primeiros tempos da ocupação, a Coroa portuguesa já as incentivava ao distribuir sesmarias a quem dispusesse de meios necessários para desenvolvê-las. A princípio, o abastecimento de gado para as Minas Gerais proveio das regiões do norte da colônia, das planícies do sul, e também da extensão meridional dessa própria região. ${ }^{149}$ A partir da segunda metade do século XVIII, sobretudo com a da crise da mineração, as populações locais passaram a se dedicar mais a essas funções de maneira exclusiva ou conjugando-as com a mineração. ${ }^{150}$

A dinâmica do abastecimento de gado acabou desencadeando uma série de funções que envolveram criador, que poderia ser um grande homem de negócio, um pequeno produtor, ou simplesmente um negociante que comprava esse gênero para revender em um local onde já contava com um mercado estabelecido. Na Comarca de Vila Rica predominaram proprietários com pequenos plantéis, que possuíam em média 10 cabeças de gado, fato que pode ter contribuído para a permanência de um abastecimento externo, ainda que se apresentasse em declínio na segunda metade do século XVIII. ${ }^{151}$ Essa atividade contou então com a mão-de-obra de pessoas que "viviam de suas agências”, fossem tropeiros ou os próprios negociantes. $^{152}$

O crédito também movimentou essa categoria do abastecimento, financiando as atividades comerciais. As mercadorias oriundas do Reino pareciam ser negociadas com

149 ALMEIDA, Homens ricos, homens bons, p.114-115. Cf. PRADO JÚNIOR, Caio. Formação do Brasil Contemporâneo. $13^{\mathrm{a}}$ ed. São Paulo: Basiliense, 1973, 189.

${ }^{150}$ ZEMELLA, O abastecimento da capitania das Minas Gerais, p. 175. O estudo de Carla Almeida a partir de inventários dos moradores das comarcas do Rio das Mortes e Vila Rica destaca que entre 1750 e 1850 foram encontradas unidades produtivas classificadas como de agricultura, de pecuária, de mineração, de agropecuária, agricultura e mineração e agropecuária e mineração. ALMEIDA, Homens ricos, homens bons, p.10. Para a região específica de Mariana não ocorreu grande variação, sendo as unidades produtivas exclusivamente mineradoras, agrícolas-mineradoras, e pecuaristas mineradoras. As que não tinham mineração foram agrícolas, peciaristas e agropecuaristas. ALMEIDA, Alterações nas atividades produtivas mineiras, p.90.

${ }^{151}$ ALMEIDA, Homens ricos, homens bons, p.133.

152 BORREGO, Maria Aparecida de Menezes. A Teia Mercantil: negócios e poderes em São Paulo colonial (1711-1765). Doutorado em História. FFLCH - USP, 2006, p. 86. 
fornecedores da Bahia e do Rio de Janeiro, mas os produtos produzidos na colônia, ou ainda nas proximidades das Minas, tiveram a distribuição a partir de conexões internas estabelecidas entre os mineiros. ${ }^{153}$ As cobranças desses negócios referentes à distribuição de bens de consumo parecem ter sido mais rigorosas no que se refere ao âmbito das redes instituídas entre os comerciantes. Tratava-se de uma cadeia de endividamentos e não havia de se esperar muito pelos pagamentos de bens de consumo, uma vez que a utilização do crédito se deu de maneira sucessiva, ou seja, adquiria-se uma mercadoria com o prazo para o pagamento, mas também se vendia com a condição de receber depois.

O negociador de gados, José Gonçalves da Mata, preto forro, morador em Mariana, teve como seu fornecedor o Alferes Domingos José Rodrigues. Apesar da lida com tratos comerciais que despendiam valores mais elevados, José não sabia ler nem escrever. Nos momentos em que necessitava, recorria a terceiros para firmar seus negócios, conforme aconteceu em julho de 1792, quando solicitou a João Manoel Novais para que compusesse dois bilhetes de crédito em seu nome e ainda servisse de testemunha para a transação. O primeiro com data de 7 de julho e o segundo de 19 do mesmo mês. Cada bilhete correspondia à compra de doze cabeças de gado, sendo um no valor de 57 oitavas, que deveriam ser satisfeitas em dois meses a partir daquela data, e o outro de 56 oitavas de ouro, no termo de um mês e meio.

Por algum motivo não mencionado, José Gonçalves não conseguiu quitar sua dívida. Logo, em outubro de 1792, o Alferes Domingos o fez citar pela justiça para o cumprimento da negociação firmada entre os mesmos. Cobrava a quantia de noventa e quatro oitavas de ouro.

Essa ação parece não ter prosseguido normalmente. Depois de ser citado, somente em setembro de 1793 o réu apresentou uma petição à justiça. Nesse documento, solicitou o abatimento de dois recibos anexados, um de 17 oitavas quitadas em 17 de outubro de 1792, outro de três oitavas e seis vinténs de ouro em 16 de novembro do mesmo ano e outro de 12 oitavas quitadas em 21 de maio de 1793. É importante observar que mesmo estando a cobrança em juízo, as tentativas de recebimento do valor foram constantes. Encontram-se anexados ao processo alguns bilhetes, ou recados por escrito, em nome de João Gonçalves de Castro, um portador de bestas e suposto cobrador do autor, solicitando que lhe fossem enviados os pagamentos.

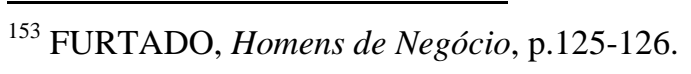


A relação de proximidade, inerente entre pessoas que se valiam do crédito para manter seus negócios, é percebida nesse caso a partir dos recados enviados ao devedor, sempre acompanhados de felicitações e desejos de saúde ao remetente; seu maior objetivo, contudo, era a solicitação da cobrança de pagamentos referentes a um bilhete de "nove oitavas e tanto” passado pelo filho do José Gonçalves, e a necessidade de recebimento, por motivo de “carência” por parte do destinatário. As respostas se davam a partir de promessas adiadas do pagamento, o que fez com que Domingos José Rodrigues lembrasse em um último bilhete que a obrigação do pagamento passaria a José Antônio de Freitas, possivelmente fiador do réu. As contas do processo pareciam somar $116 \$ 025$ mil réis. O pagamento se procedeu depois da audiência pública de 11 de setembro de 1793, quando,

\footnotetext{
(...) apareceu presente José Antônio de Freitas, que ele me foi dito em presença das testemunhas (...) que ele procurador bastante do Alferes Domingos José Rodrigues, (...) que se achava junto nestes autos dava plena e geral quitação ao Réu José Gonçalves da Mata dito deu principal [sic] e custas contadas nestes autos, pois mais lhe não ser pedido em tempo algum, pois da mesma quantia estava pago e satisfeito (...). ${ }^{154}$
}

Não sabemos qual o motivo levou José Antônio de Freitas a arcar com a dívida de José Gonçalves. Pode ter sido a partir de um empréstimo, fazendo com que o procurador do autor se tornasse o novo credor desse liberto. Caso tenha procedido dessa forma, é possível afirmar que a dívida ainda permanecia em aberto, mas agora o pagamento deveria ser dirigido a outra pessoa. Essa parecia ser uma prática comum na colônia.

Esse caso nos mostra a participação de um liberto em uma importante atividade comercial, que era a distribuição de gêneros alimentícios. Ainda que fosse apenas o atravessador de um tipo de mercadoria e não um produtor, esse sujeito estava totalmente integrado na dinâmica comercial da Mariana colonial.

Uma opção de ocupação para os egressos do cativeiro seria o desenvolvimento de atividades relacionadas ao cultivo de bens necessários à subsistência. Ainda que a produção pareça se dar apenas em âmbito doméstico, alguns indícios são percebidos a partir dos registros deixados em testamentos. Felipe de Godoy, morador na Barra do Bacalhau, era casado com Joana do Couto preta forra e arrolou vários bens em 1786, dentre os quais constavam tachos de cobre, uma chocolateira, roupas, ferramentas, móveis, cavalos e um

${ }^{154}$ ACSM, Ação Cível, Códice 347, Auto 8470. 
alqueire de milho plantado. A última informação indica que sua principal ocupação foi a agricultura; além disso, era proprietário de escravos e possuía ferramentas como enxadas, foices, machados, almocafres e cavadeira. ${ }^{155}$ Maria da Silva, casada com o preto liberto Manoel da Silva também indicou ter ferramentas e 20 alqueires de milho. ${ }^{156}$

Ter acesso a um território que servisse de moradia e possibilitasse o exercício de algum ofício simultaneamente favorecia a quem pretendesse adquirir bens com o esforço de seu trabalho. Parece que Manoel do Sacramento, preto forro, morador na freguesia de São Sebastião, tentou fazer isso no ano de 1745. Em 13 de julho, passou um bilhete de crédito ao Capitão Gonçalo Lopes Camargo, morador nas Águas Claras, freguesia de São Caetano. Nesse documento, Manoel se comprometia em pagar trezentas oitavas de ouro, "procedidas da compra de uma roça cita na freguesia de São Sebastião" na condição de quitar o valor "em seis pagamentos repartidos em seis anos a cinqüenta oitavas cada pagamento”.

Tratava-se da compra de uma roça "com casas de vivenda cobertas de telha e de capim, com águas, árvores de espinho, capoeiras e matas virgens e todos os mais pertences que parte de uma banda com terras de Pedro do Monte e Manoel do Couto, e de outra com Pedro José Aleixo, Manoel das Neves e de mais com quem de resto for”. Manoel parece ter dado “como fiador e principal pagador” a Manoel do Rego Tinoco. Em primeiro de setembro de 1746, procedeu-se à primeira quitação no valor de cinqüenta oitavas de ouro, conforme especificado no contrato. No entanto, os pagamentos seguintes, efetuados em São Sebastião, não seguiram o mesmo rigor. Em 11 de julho de 1747, quitou apenas 21 oitavas. Em 1748, foram dadas três parcelas, uma de dez oitavas de ouro, outra de 4 oitavas e 4 vinténs e por fim a de 11 oitavas e meia e um tostão. A última parcela repassada totalizou 55 oitavas e três quartos de ouro, em dois de maio de 1750, ano que venceria o período estipulado para o pagamento do valor total do bem comercializado.

Em audiência pública de primeiro de fevereiro de 1751, o Capitão Gonçalo Lopes Camargo resolveu entrar com uma ação de cobrança do crédito de "noventa e quatro oitavas e meia e três vinténs de ouro de 1500 réis ${ }^{157}$, resto dos primeiros cinco pagamentos vencidos”,

\footnotetext{
155 ACSM, Inventário, Códice 117, Auto 2336.

${ }^{156}$ ACSM, Testamento, Códice 71. ACSM, Testamento, Códice 50.

${ }^{157}$ Nota-se que há divergência entre o valor da oitava de ouro especificado na historiografia e o definido nessa ação. Em outro momento, informamos que a oitava de ouro sofreu alterações ao longo do século XVIII, mas que no período compreendido entre os anos de 1751 a 1823, esse valor teria se fixado em 1.200 réis.
} 
por argumentar que Manoel do Sacramento se recusava a quitar o restante do valor referente à propriedade por ele comprada. ${ }^{158}$

Não sabemos qual o conflito se procedeu entre Manoel e seu credor, o Capitão Gonçalo. Importa destacar que esse liberto tentou fazer um investimento que só foi viável pela utilização do crédito. A impossibilidade de amealhar recursos para a quitação seria compensada com os lucros provenientes do próprio trabalho. A alteração da forma de pagamento se procedeu a partir da dificuldade em se cumprir com as determinações previamente especificadas.

\subsection{3. $O$ acesso aos imóveis}

A residência para um liberto representava mais que o simples abrigo; este era um espaço onde a autonomia e o exercício de alguma função poderiam se realizar. Os testamentos e inventários nos mostraram até mesmo a adaptação desse local como forma de angariar recursos, algo que se percebe com o casal de libertos que dividiu a casa para montar uma estalagem.

A casa era também um recinto privado, local onde todas as tarefas cotidianas eram realizadas, onde relações familiares e de agregação eram estabelecidas. A sua localização nos remete a pensar nos vínculos estabelecidos com os vizinhos, com as pessoas com quem “partiam” seus quintais, suas posses. Em Passagem, por exemplo, Antônia Rodrigues Lima, preta forra, possuía "uma morada de casas téreas cobertas de telha com seu quintal e mais pertences”, no valor de $120 \$ 000$ réis, que partia “de uma banda com o Guarda-Mor Manoel Coelho Pereira e de outra com a rua que vai para o Rio". ${ }^{159}$ Outra moradora desse distrito, Josefa Vieria Aleluia, possuía uma chácara com bananal, que partia “com terras do Tenente Antônio Mendes e com terras do Padre Bernardino Marques”. ${ }^{160}$ Antônia Fernades, moradora no Bocão, "subúrbios" da cidade de Mariana, dividia uma de suas moradas com casas do Sargento Mor Antônio Luiz Pimenta. ${ }^{161}$ Justa Maria Gonçalves, a mesma citada anteriormente por possuir jóias mais modestas que outra liberta, tinha uma casa no Pissarrão que partia com

\footnotetext{
${ }^{158}$ ACSM, Ação Cível, Códice 469, Auto 15261.

${ }^{159}$ ACSM, Inventário, Códice 101, Auto 2104.

${ }^{160}$ ACSM, Inventário, Códice 80, Auto 1690.

${ }^{161}$ ACSM, Inventário, Códice 92, Auto 1918.
} 
“casas de Antônio José Leite e da outra com quintal do Padre Luiz Antônio da Costa. ${ }^{162}$ Manoel de Souza, morador na Rua Nova, partia sua casa pela "parte de cima com casas do Capitão Mor José Alves Maciel, e pela de baixo com as casas do Reverendo Cônego Domingos Fernandes”. 163

Esses libertos poderiam ter como vizinhos sujeitos de mesma origem social ou pessoas que tinham certo destaque naquela sociedade. Fossem na cidade, suas adjacências ou distritos mais distantes do espaço urbano, é certo que alguma relação de convívio havia entre os mesmos. Muitas das conexões clientelares estabelecidas pelos libertos poderiam ter início a partir dessa aproximação.

Os tipos de moradias adquiridas pelos forros da região de Mariana foram diversos, chácaras e sítos nas localizações rurais, ou casas térreas e assobradadas na região urbana. As descrições mais gerais eram de casas térreas cobertas de telhas com quintal, bananal, frutas em geral, ranchos e paiol. Muitas delas eram feitas de pedra, mas também havia casas de madeira. Os valores desses imóveis variavam de acordo com sua localização e suas condições de preservação. Diogo de Souza Coelho era proprietário de duas casas de morada no Monsus, uma era térrea, coberta de telha, que valia 60\$000 reís, a outra foi descrita como velha que valia apenas $12 \$ 000$. Os valores mais encontrados estão na faixa entre $50 \$ 000$ e $100 \$ 000$ ou $120 \$ 000$ réis, mas também apareceram imóveis com valores inferiores e superiores a esses.

A composição das casas era simples, ou até mesmo desprovidas de conforto, pois móveis e adornos eram parcos. É certo que houve quem se preocupasse com a aparência de suas casas, como Josefa Martins, que possuía entre mesas, tamboretes e caixas de guardar mantimentos, adornos como um oratório e imagens e um catre de Jacarandá. ${ }^{164}$ Manoel de Souza preto forro, morador na Passagem, possuía entre outros bens uma mesa de Jacarandá torneada, um banco com encosto, outro sem encosto, dois catres de Jacarandá torneados e dois catres de madeira branca, lisa. ${ }^{165}$ Itens de mobiliário mais sofisticados não apareciam com frenqüência nesses inventários. Muitas dessas peças eram de extrema importância ao mobiliário, mas foram comuns as descrições que as definiam como velhas ou de muito uso.

Ainda que representassem distinção, os objetos e tecidos de uso doméstico, adornos para casa, peças do vestuário e jóias não representavam os itens de maior valor nos inventários; as somas elevadas se davam sobretudo com os escravos, seguidos das casas de

\footnotetext{
${ }^{162}$ ACSM, Inventário, Códice 82, Auto 1751.

163 ACSM, Inventário, Códice 138, Auto 2792.

164 ACSM, Inventário, Códice 106, Auto 2183.

165 ACSM, Inventário, Códice 138, Auto 2792.
} 
morada. Talvez isso tenha contribuído para que dívidas com compra de casas tenham sido igualmente contraídas pelos libertos. Adquirir o próprio local de moradia representava grande empenho por parte do comprador, mesmo que se tratasse de instalações mais modestas. A quitação de um imóvel geralmente se estendia por um período longo, o que poderia acarretar no processo de endividamento do investidor.

As prestações com compra de casas eram dispendiosas aos libertos, que ainda assim se esforçavam por fazê-lo. Alguns entraram nesse tipo de aquisição apenas no final de suas vidas, e, portanto, faleciam sem que a quitação completa fosse efetivada. Quando Rosa da Silva preta forra, moradora no Rosário, fez suas disposições testamentárias em 1753, declarou ser proprietária de "uma casa de sobrado com seu bananal”, das quais ainda devia 77 oitavas de ouro ao antigo proprietário, Francisco Lopes. Essa dívida seria quitada por seu escravo Antônio Ganguela, pessoa que tomaria posse dessa moradia e de “todos os bens móveis" que lhe pertenciam, após a sua morte. A negociação entre os mesmos indicava o pagamento de 192 oitavas de ouro, “fiadas em 4 anos”. O primeiro valor dessa prestação deveria ser entregue ao testamenteiro, que logo o passaria ao credor da casa. ${ }^{166}$

Caso essa dívida não fosse quitada, o credor recorreria à justiça para tentar receber o valor que lhe era de direito. Foi isso que aconteceu com muitos que venderam imóveis a libertos e não tiveram a contrapartida no cumprimento da obrigação.

Em 1779, Maria Jorge Pinta preta forra comprou uma casa de morada pertencente ao Capitão Manoel Jorge Pinto pelo valor de duzentos e dez mil réis. Tratava-se de uma casa “térrea, assobrada, coberta de telhas com seu quintal”, que ficava na Rua Nova, cujas delimitações partiam com a casa do Capitão João Marques Pimenta. O primeiro pagamento foi passado nesse mesmo ano, no dia 5 de setembro, mas ao que tudo indica nenhum outro valor fora efetuado.

O Capitão Manoel acabou falecendo. Não sabemos qual o critério que havia adotado para receber as prestações com a venda da casa, mas nota-se que fora extremamente tolerante com a inadimplência da devedora. Sabemos que a abertura de um testamento e a feitura do inventário se procedia logo após a constatação do óbito. Dessa forma, inferimos que as cobranças mais rigorosas somente se processaram após a morte do credor, uma vez que suas relações com o devedor eram mais estreitas quando envolviam um testamenteiro.

\footnotetext{
${ }^{166}$ ACSM, Testamento, Livro 64.
} 
Para essa função fora escolhido Manoel Jorge Pinto, que fez questão de formalizar os contratos estabelecidos verbalmente pelo testador. Provavelmente foi a seu pedido que, em 03 de fevereiro de 1783, Maria, a rogo do ajudante Inácio Francisco Floriado, passou um bilhete de crédito afirmando dever ainda cento e setenta e um mil réis do valor da casa. As condições especificadas para a quitação daquele valor seriam de "pagamento cada ano por oitavas em trinta e seis oitavas e meia e três vinténs de ouro”. Nesse momento, parecia estar com todas as parcelas vencidas, motivo que levou o testamenteiro a recorrer à justiça com o objetivo de solicitar a quantia então determinada.

Maria não se encontrava morando na casa comprada no período em que a petição de citação foi entregue à justiça. Mas Manoel Jorge teve informações de que estava assistindo no Arraial do Camargos, em casa de Maria Coelha crioula forra. Não sabemos qual a relação entre essas libertas, mas as solicitações do autor eram de que, na ausência da ré, a crioula fosse citada "para a fazer ciente observando-se a forma da lei”. O mandado de citação foi despachado em 10 de setembro de 1782; no entanto, a citação só ocorreu em 9 de janeiro de 1783, para comparecer à audiência pública do dia 06 de fevereiro do mesmo ano. Por falta de apresentação da ré, o caso foi julgado à sua revelia, sendo condenada em 20 de fevereiro de 1783 ao pagamento da quantia pedida e às custas da ação. ${ }^{167}$

A casa comprada por Maria de Souza da Conceição preta forra custou cento e quarenta oitavas de ouro e também foi cobrada pelo testamenteiro Antônio Lourenço Correa, do vendedor Crispim Martins, já falecido. A residência ficava na Rua São Gonçalo e se localizava “de uma banda (...) com casas de Agostinho de Sá e da outra com casas de Antônio Coelho Lamas [sic]”. Segundo o contrato estabelecido na venda, em 1759, o valor deveria ser dividido em duas parcelas anuais, a primeira em 1760 e a segunda em 1761. Maria ainda apresentou como seu fiador Agostinho Dias de Abreu. Mas, conforme recibos anexados à ação, essa liberta só conseguiu fazer dois pagamentos, um no valor de quatorze oitavas e um quarto de ouro, em 20 de fevereiro de 1761, e outro de dez oitavam em 23 de março do mesmo ano.

Isso fez com que o Furriel Antônio Lourenço Correa recorresse aos meios legais para que pudesse dar conta da testamentaria do falecido Crispim. Em petição entregue à justiça em 24 de maio de 1762, Maria reconheceu a dívida e solicitou que fosse tomada sua confissão para evitar as custas com aquela ação, o que imediatamente foi feito. Contudo, não foram

${ }^{167}$ ACSM, Ação Cível, Códice 600, Auto 22881. 
poupados os gastos; em 6 de junho, foi condenada a pagar a quantia pedida e os custos despendidos com o processo, que somavam cento e trinta e oito mil e novecentos réis. ${ }^{168}$

Inácia Freire preta forra tentou comprar em 19 de março de 1747 uma moradia no valor de 100 oitavas de ouro, que foi de Maria Lopes do Anjos. Tratava-se de uma morada de casas térreas na "Ladeira da Senhora Santana" que partia de uma "banda de casas de Manoel da Silva e outra com Francisco da Silva Leite”. Em documento feito a rogo de Manoel de Almeida Perdigão, essa liberta se comprometia a efetuar o pagamento no período de dois anos e três meses, caso contrário poderia ser executada pela mesma ou por quem lhe mostrasse aquele papel. Nesse mesmo dia, foi efetuado um pagamento no valor de 36 oitavas e 12 vinténs de ouro, ficando o restante sem definição da condição de pagamento.

Em julho de 1750, Francisco Machado de Magalhães recorreu à justiça argumentando não ter recebido mais a conta daquele contrato. Não sabemos exatamente qual a ligação do autor com a vendedora da casa, talvez seu marido, ou alguém que estivesse intercedendo com seu consentimento. Mas Inácia logo conseguiu um fiador que lhe passou o valor pedido pelo autor. Trata-se de Luis da Silva Machado, morador no Sumidouro, que se apresentou à justiça em 16 de julho para fazer termo de fiança, quando foi dito que "muito de sua livre vontade e sem constrangimento de pessoa alguma, ficava (...) como fiador e principal pagador a quantia”. ${ }^{169}$ Apesar de quitar o valor pedido em juízo, Inácia não se livrou da dívida contraída com a compra da casa; suas pendências apenas se transferiam de uma pessoa a outra, das mãos do cobrador para o fiador.

As residências até então citadas não eram tão modestas, se considerarmos que valores bem inferiores a esses foram encontrados nos inventários. O valor das casas cobradas em instância juducial não ultrapassou 200 mil réis, quantia equivalente a um escravo em idade e condições favoráveis a bons rendimentos em qualquer ocupação. Mas, ainda assim, ficavam nas regiões mais centrais da cidade. ${ }^{170}$

Outra liberta investiu mais em sua futura moradia, pois gastaria quase o dobro que as mulheres até então citadas. Em 20 de agosto de 1749, Maria Cecília comprou uma casa de Domingos Ferreira de Azevedo, situada na Rua Nova, no valor de quatrocentos e vinte e cinco mil réis, tendo como seu fiador e principal pagador Domingos Álvares Aguiar. O pagamento

\footnotetext{
${ }^{168}$ ACSM, Ação Cível, Códice 498, Auto 16943.

169 ACSM, Ação Cível, Códice 452, Auto 9791.

170 Ida Lewkowicz percebeu que a pobreza e a riqueza conviviam muito proximamente dentro das áreas que analisou para o ano de 1819 na cidade de Mariana. Residências bem avaliadas e pertencentes a pessoas de destaque na sociedade eram margeadas por casas simples, de pouco valor, alugadas ou de propriedade de pessoas muitas vezes consideradas como indigentes nos recenseamentos analisados. LEWKOWICZ, Vida em família, p. 94.
} 
da casa seria dividido no termo de três anos em parcelas anuais, dando ainda como uma dessas parcelas um crédito, “de cento e dez oitavas que do Reverendo Padre Simão Peixoto de Faria para este se cobrar por minha conta o risco e cobrado que seja se receber neste a sua importância”.

Em fevereiro de 1751, sem receber qualquer valor, Domingos Ferreira de Azevedo entrou com uma ação judicial para cobrar a primeira parcela vencida e ainda protestar e entregar o crédito assinado pelo Padre Simão Peixoto.

O negócio entre a liberta e esse padre havia gerado alguns problemas, pois se tratava da venda de uma escrava que se encontrava penhorada. Devido a isso, o pagamento referente ao bilhete de crédito não foi feito. Somente depois de uma demanda judicial, a vendedora se viu livre de tal penhora e o comprador pôde tomar posse do seu bem. Foi quando Domingos Ferreira mandou um camarada seu ao Serro Frio, local onde Simão Peixoto estava residindo, com o intuito de receber a primeira parcela. Essa viagem acabou gerando uma despesa de quatorze oitavas de ouro, que, somada aos quatrocentos e vinte e cinco mil réis referentes à casa e às custas dos autos, representou a quantia em que ficou condenada a ré. ${ }^{171}$

Essa ação mostra uma característica importante da economia colonial, a circulação dos bilhetes de crédito como forma de pagamento. Percebe-se que não era somente a palavra empenhada que garantia a efetivação de um negócio, pois documentos de terceiros também poderiam ser aceitos como quitação, mesmo que exigissem esforço do credor para transformálos em moeda corrente. ${ }^{172}$

As condições econômicas dessa liberta não foram favoráveis a ponto de cumprir seus tratos comerciais sem que houvesse a interferência da justiça; no entanto, os indícios são de que esteve envolvida em outras negociações. Ainda que não desfrutasse de um padrão econômico estável, sua apresentação ao circular pela cidade parece ter sido mantida com algum rigor, pois lançava mão dos serviços de Manoel Antônio Pereira, oficial de cabelereiro, a quem também ficou devendo certa quantia no ano de $1751{ }^{173}$

Ao que tudo indica, Maria Cecília vivenciou certa restrição econômica nesse período, o que talvez a tenha levado à justiça para também requerer quantias em moeda. Em 1752 entrou com uma ação judicial para cobrar Manoel de Abreu Távora pela criação de uma

\footnotetext{
${ }^{171}$ ACSM, Ação Cível, Códice 393, Auto 10911.

172 Raphael de Freitas denominou esse tipo fenômeno como “cessão de dívida” ou "trespasse de dívida”, que consistia "no repasse de uma dívida contraída a um terceiro, que passaria a ser, a partir daquele momento, o novo devedor”. SANTOS, Devo que pagarei, p.130-131.

${ }^{173}$ Maria Cecília foi citada pela justiça depois que Manoel Antônio Pereira solicitou em petição que fosse jurar em sua alma se era ou não devedora da "quantia de dez oitavas de ouro procedidas de obras de seu ofício de cabelereiro”. ACSM, Ação Cível, Códice 622, Auto 241888.
} 
menina escrava; argumentava tê-la cuidado e ensinado por mais de sete anos, sem que houvesse qualquer pagamento ou ajuda financeira por parte do seu proprietário. Em contrapartida, o réu argumentava ser ele quem deveria receber os jornais pelo tempo em que havia ficado em posse da cativa, pois quando fora para o poder da autora ela já era dotada de alguns ensinamentos. Também acusou Maria Cecília de se aproveitar daquela situação por estar passando por dificuldades econômicas. ${ }^{174}$ As condições que essa liberta enfrentou a partir desse período é desconhecida por nós, mas em 1760 entrou com outra reivindiação de posse de um crioulo contra o Capitão Leonel de Abreu Lima. ${ }^{175}$ Fosse por restrição financeira ou por tentativa de manter a honra ao efetuar um negócio, a questão é que os libertos puderam levar às instâncias judiciais suas reclamações a partir dos direitos que a liberdade lhes conferia. Era também uma forma de se afirmarem na sociedade colonial.

Ao trabalharmos com as ações de cobranças não podemos nos esquecer de algumas limitações que essa fonte documental apresenta. Em primeiro lugar, é importante salientar a ausência do desfecho de grande parte dos processos consultados. Não sabemos se isso se deu pela desistência de uma das partes a partir da morosidade da justiça, ou por falta de recursos na manutenção da ação. A demora de algumas sentenças dessas ações ocorreu em grande medida nos casos em que as cobranças se dirigiam a pessoas residentes em outras freguesias. Quando se tratava de moradores de Mariana, desde que se apresentassem corretamente e reconhecessem suas dívidas, poderiam ser condenados no mesmo mês da citação judicial.

Havendo ou não o desfecho dos casos, deparamo-nos ainda com outra limitação: a falta de informações sobre a sua execução. Sabemos que a pessoa foi condenada, mas não conhecemos a conclusão do caso. Isso, no entanto, não compromete a riqueza das informações que esse corpus documental nos oferece.

A historiografia revelou que o endividamento era corriqueiro na sociedade colonial, pois se comprava tudo a crédito. Com os libertos, isso não se processou de maneira diferenciada, uma vez que lançaram mão dessa prática para os mais diferenciados tipos de negócios. Se, por um lado, adquiriam bens apenas para o consumo, por outro, tiveram a possibilidade de fazer investimentos que renderiam lucros e que eventualmente proporcionariam melhores condições de vida.

O acesso a diferentes recursos demonstra que o grupo dos libertos não pode ser visto somente pelo prisma da desclassificação. A utilização do crédito previa a existência de

\footnotetext{
${ }^{174}$ ACSM, Ação Cível, Códice 296, Auto 7145, 1752, Sem desfecho.

175 ACSM, Ação Cível, Códice 412, Auto 12000, 1760. Consta apenas abertura do processo.
} 
vínculos entre credores e devedores, e, em alguns casos, isso pode ser percebido a partir da tolerância que houve em relação aos atrasos dos pagamentos firmados em um negócio. Alguns processos eram iniciados anos depois que a dívida havia sido contraída, indicando a possibilidade de favorecimento do devedor. O mesmo não aconteceu quando as cobranças eram feitas por terceiros como testamenteiros e herdeiros desses credores.

O fato dos libertos terem adquirido posses fez com que alguns favorecessem indivíduos de mesma origem social, sendo credores nas transações comerciais. Mas a existência de ações judiciais de cobranças demonstra que nem todos os negócios eram resolvidos em âmbito privado. É importante destacar que, por mais que o crédito lhes proporcionasse recursos ou a garantia do próprio sustento, a utilização dessa prática gerava endividamento que, sendo agravado, poderia ocasionar em situação de pobreza. 


\section{CAPÍTULO 4}

\section{Forros: uma condição social instável}

Por maiores que fossem as dificuldades atreladas à conquista da liberdade, muitos foram os escravos que se empenharam e alcançaram a tão sonhada manumissão. Apesar da existência de estudos sobre as alforrias no período colonial, o resultado da maior parte desses trabalhos nos fornece apenas dados parciais sobre essa prática; as pesquisas disponíveis, por exemplo, mesmo que tragam estimativas, não quantificam de modo preciso o número de escravos libertados em Mariana ao longo do século XVIII. Afora isso, devemos lembrar que, uma vez que havia a potência legal da anulação de uma carta ou de um processo de libertação, para o liberto, coartado ou 'escravo sob condição', a possibilidade de retornar à escravidão era algo tangível.

\subsection{O direito da alforria}

Não nos surpreende a presença de conflitos nos processos de alforria, se pensarmos que, antes da década de 1860, as libertações se davam por meio de preceitos socialmente estabelecidos, denominados pela historiografia como "direito costumeiro”. ${ }^{1}$ Esses processos nos parecem muito mais intricados do que uma simples troca de favores ou uma operação de mercado; seus desfechos, quando não resolvidos no âmbito privado, transpunham as relações senhor - escravo em direção às instâncias judiciais. O Estado, nessas situações, interferiu em grande medida como mediador dos conflitos, muito embora suas ações tenham sido reconhecidas pelos pesquisadores como uma forma de reiteração da posição senhorial. ${ }^{2}$

\footnotetext{
${ }^{1}$ Termo utilizado por Manuela Carneiro da Cunha para definir o "espaço das relações privadas de dependência do poder”, ou seja, o espaço estabelecido no âmbito senhorial, que permitia aos escravos o acesso à liberdade. CUNHA, Manoela Carneiro da. "Sobre os silêncios da lei: lei costumeira e positiva nas alforrias de escravos no Brasil do século XIX”. Antropologia do Brasil: mito, história, etnicidade. São Paulo: Brasiliense, 1986, p.123141. Cf. GRINBERG, Keila. Liberata: a lei da ambigüidade: as ações de liberdade na Corte de Apelação do Rio de Janeiro, século XIX. Rio de Janeiro: Relume-Dumará, 1994, p.39. Cf. CASTRO, Hebe Maria Matos de. Das cores do silêncio: Os significados da liberdade no sudeste escravista. Rio de Janeiro: Nova Fronteira, 1998, p.193.

${ }_{2}^{2}$ Para explicar essa questão, Keila Grinberg faz uma discussão a respeito das vertentes historiográficas que tratam da influência exercida pelos oficiais da justiça nos julgamentos das ações de liberdade, uma vez que esses representavam simultaneamente a classe dominante e o Estado, que por excelência defendiam a escravidão. A autora expõe as críticas feitas por Jacob Gorender aos historiadores que vêem a atuação dos escravos nesses processos como atitudes de autonomia. Para Gorender não se pode falar em autonomia nas negociações, pois os escravos somente chegavam às instâncias judiciais pela intermediação dos representantes da elite colonial.
} 
A partir dos preceitos sociais estabelecidos, também é possível entender o fato de escravos em processo de libertação terem recorrido ao Estado, na vigência do sistema escravista, para reclamar o direito de liberdade negligenciado pelo senhor. ${ }^{3}$ Ainda que a maior parte das alforrias fosse registrada em cartório, como forma de impedir a ameaça de reescravização, o reconhecimento da liberdade, por vezes, também foi estabelecido socialmente, cabendo então à justiça julgar se um indivíduo era livre ou não.

As relações costumeiras concebiam a possibilidade de interferência da justiça no domínio senhorial, o acesso dos escravos às instâncias judiciais, por intermédio de uma pessoa livre, e o reconhecimento da condição social de um indivíduo. Não obstante, os argumentos daqueles que buscavam as instâncias judiciais eram conformados pelos protocolos e regras jurídicas. Se, por um lado, as Ordenações Filipinas resguardavam direitos aos proprietários de revogação da alforria de seus escravos, seja para as concessões onerosas ou incondicionais, por outro, também instituíam que eram fortes as razões que levavam à libertação. ${ }^{4}$ A legislação, contudo, não fez nenhuma menção às formas de libertação e tampouco descreveu o perfil do cativo mais apto à conquista da manumissão. As alforrias, mesmo que pagas, dependiam da disposição do proprietário em se desfazer de parte de suas posses.

Diante da legislação, as manumissões eram vistas como doações, termo que aparece repetidas vezes no item das Ordenações Filipinas que trata das revogações. ${ }^{5}$ Dádiva ou doação, essa prática reforçava ainda mais as relações de fidelidade entre doador e donatário, perpetuando-a para além do período do cativeiro. Nas palavras de Márcio de Sousa Soares, é importante

\footnotetext{
Thompson e Genovese também entendem o exercício do direito como instrumento de afirmação da classe dominante, mas em contrapartida, consideram sua atribuição mediadora exercida nos conflitos entre diferentes as classes, podia gerar diferentes desfechos, favorecendo ou não a classe dominante. GRINBERG, Liberata, p. 3336. Cf. GORENDER, "Violência, consenso e contratualidade". A escravidão reabilitada. $2^{\mathrm{a}}$ Edição. São Paulo: Editora Ática, 1991, p.19-43.

${ }^{3}$ Keila Grinberg explica esse fator a partir de uma adaptação da legislação, inicialmente não prevista para os escravos. O artigo do Livro $3^{\circ}$, Título 5, Parágrafos 3 a 5 das Ordenações Filipinas garantia a nomeação de curadores para os indivíduos incapacitados de administrar seus interesses; dentre eles órfãos, as viúvas e miseráveis. A justiça, portanto, adotou a última classificação para a nomeação de curadores aos escravos, a de miseráveis. Outra explicação que pode sugerir respostas a esse fato não se refere a leis, mas sim "das relações pessoais que um escravo mantivesse com homens livres e poderosos do local". Ou seja, quanto mais próximo do mundo dos livres, maiores seriam as chances de um escravo dispor de meios que o possibilitasse o acesso às esferas judiciais. GRINBERG, Liberata, p. 64-67. Cf. MATTOSO, Kátia de Queirós. Ser escravo no Brasil. $3^{\circ}$ Edição, São Paulo: Brasiliense, 2001, p. 179-180.

${ }^{4}$ ORDENAÇÕES FILIPINAS, ordenações e leis do reino de Portugal recopiladas por mandato d'el Rei D. Felipe, o primeiro, editado por Cândido H. Mendes de Almeida. 5 vol. São Paulo: Edição Saraiva, 1960, Cf. CASTRO, Das cores do silêncio, p. 201. Cf. GRIMBERG, Liberata, p. 31.
}

${ }^{5}$ ORDENAÇÕES FILIPINAS, Livro IV, título LV, p.863-867. 
Entender que, pela lógica da economia moral do dom, o doador continua a exercer direitos sobre a coisa dada e, por meio dela, sobre aquele a quem ela foi dada e que a aceitou, possibilita a compreensão da enorme naturalidade com que os doadores (não só de alforrias) estabeleciam diversas condições para a doação, previam motivos para revogação da mesma ou sobre o destino da coisa doada mesmo depois de efetivada a dádiva, como aparece em várias disposições testamentárias não só em relação às alforrias como também aos bens legados a terceiros. ${ }^{6}$

Parecia ser importante para um senhor que o caráter de benevolência estivesse presente nas intenções de alforria. Antônio Mina pagou pela sua coartação a quantia de 400 mil réis, mas seu antigo senhor Antônio Martins Corvo não quis passar o documento que garantiria sua nova condição. Argumentou que só o faria se o ex-escravo o servisse e confessasse "haver recebido dele a liberdade gratuita". ${ }^{7}$ Ainda que houvesse contrapartida do pagamento, a concessão da liberdade certamente tinha um peso importante nas relações estabelecidas entre o senhor e o liberto, reproduzindo traços característicos de poder. O doador era sempre visto como um sujeito potencialmente designado à proteção do donatário; em troca disso, a gratidão parecia ser uma dívida interminável. ${ }^{8}$

Rosa Maria de Carvalho manteve laços próximos com seu antigo senhor, o Alferes Joseph Carvalho de Andrade, pois em suas disposições testamentárias indicou dever ao mesmo sete oitavas de ouro de 1500 réis, além de lhe deixar de esmola mais dez oitavas. ${ }^{9}$ Miguel Rosalis, morador no Morro Santana, deixou esmolas de 10 oitavas de ouro ao seu antigo senhor Antônio Rosalis dos Prazeres; caso não estivesse mais vivo, esse valor deveria ser revertido a missas pela sua alma. ${ }^{10}$ Quitéria Cardosa preta forra deixou trinta missas pela alma do seu antigo senhor e mais trinta pela alma da sogra do mesmo. ${ }^{11}$ Josefa Vieira Aleluia deixou 20 missas pela alma de seu patrono, João Vieira Aleluia. ${ }^{12}$

Fosse por gratidão ou simples cumprimento de uma obrigação, importa ressaltar que os antigos senhores acabavam por serem lembrados. Tampouco podemos esquecer que, no caso das concessões de alforria, mesmo se tratando de um processo em que a soberania do senhor determinava a possibilidade de doação, desconsiderar o papel do escravo representaria

\footnotetext{
${ }^{6}$ SOARES, Márcio de Souza. "A dádiva da alforria e o governo dos escravos no Brasil colonial (Campos dos Goitacazes, c. 1750 - c. 1830)”. LPH - Revista de História. V.01, n.1. Mariana: Departamento de História, UFOP, 2004-2005, p.14.

${ }^{7}$ ACSM, Ação Cível, Códice 308, Auto 7394, 1756.

${ }^{8}$ HESPANHA, Antônio Manuel; Xavier, Ângela. “As redes clientelares”. In: MATTOSO, José (Org). História de Portugal; o antigo regime. V4. Lisboa: Editorial Estampa, 1993, p. 345.

${ }^{9}$ ACSM, Testamento, Livro 69.

${ }^{10}$ ACSM, Testamento, Livro 55, 1769.

${ }^{11}$ ACSM, Testamento, Livro 55.

${ }^{12}$ ACSM, Inventário, Códice 80, Auto 1690.
} 
um equívoco, uma vez que, "para receber a dádiva da alforria era necessário fazer por merecer". ${ }^{13}$ Conforme observamos na historiografia, variados foram artifícios utilizados pelos escravos na conquista da alforria. ${ }^{14}$

A partir do levantamento dos registros cartoriais, percebemos que muitos fatores associados ao "fazer por merecer" determinavam o desfecho de um processo de libertação. As ações cíveis que envolviam as questões relacionadas ao acesso à liberdade mostram, em grande medida, como a nova realidade das pessoas em processo de emancipação interferiu na sua efetivação. As cláusulas estabelecidas nos contratos eram especificadas nas cartas de corte ou em testamentos, e foram seguidas rigorosamente por parte dos proprietários ou pelos testamenteiros daqueles já falecidos. A infração de algumas dessas cláusulas foi o que gerou a série das ações que serão examinadas a seguir.

As ações cíveis julgadas em Mariana na segunda metade do século XVIII que envolveram escravos ou ex-escravos em conflitos somam 41 processos. Desses, 20 se denominam como ações de liberdade e 17 como redução ao cativeiro. ${ }^{15}$ Outras denominações, que se referem a embargos de ações de liberdade, comprovações de liberdade, dentre outros, são encontradas em menor número.

As ações de redução ao cativeiro eram iniciadas por proprietários de escravos, enquanto as ações de liberdade tendiam a tratar de libertos que buscavam na justiça manter a condição conquistada. Ainda foram encontrados casos de cobrança de liberdade ou reivindicação de escravo, que se referiam à compra da alforria por um cativo ou por uma terceira pessoa, ou simplesmente a casos em que não havia envolvimento direto de senhores e seus escravos.

As ações relativas à falta de pagamento da libertação geralmente foram negociadas pela modalidade denominada como coartação. A maior parte delas não remete a fatos ocorridos com os libertos, mas sim a escravos em processo de libertação, ou seja, aos "libertos

\footnotetext{
${ }^{13}$ SOARES, Márcio de Souza. "A dádiva da alforria”, p.12. Há alguns anos, a historiografia vem demonstrando que a carta de alforria, antes de representar um ato de generosidade, é uma concessão senhorial, que pode também pode ser lida como um ato comercial. Dessa forma, a arbitragem do senhor era reforçada no momento em que os escravos se empenhavam na busca pela liberdade. CASTRO, Das cores do silêncio, p.172-173; MATTOSO, Ser escravo no Brasil, p. 186.

${ }^{14}$ PAIVA, Eduardo França. Escravos e libertos nas Minas Gerais do século XVIII; estratégias de resistência através de testamentos. São Paulo: Annablume, 1995.

${ }^{15}$ Os casos classificados como redução ao cativeiro ou reversão à escravidão seguem essa denominação pelo fato desses termos aparecerem nas petições que davam início à ação cível. Em se tratando de escravos em processo de libertação, essa denominação nos parece adequada, uma vez que o "liberto sob condição" apresentava uma condição intermediária entre a escravidão e a liberdade. Mas, no que se refere aos libertos, o termo que nos parece mais adequado é o de revogação de liberdade, pois possuíam um documento que indicava esse status. Dois processos classificados como ações de liberdade apresentam características de redução ao cativeiro, pois foram iniciados por testamenteiros de antigos senhores que tentavam reaver escravos coartados que não pagavam as parcelas da alforria.
} 
sob condição”, termo empregado por Kátia Mattoso para tratar dos indivíduos que já não eram escravos, mas que também não haviam alcançado o status de liberto. ${ }^{16}$ Também há situações de anulação da alforria prometida por motivo de desrespeito ao antigo senhor ou a alguma cláusula ou condição prévia para a sua efetivação. Outras ações aludem mais a pessoas que “se diziam livres” da escravidão e que buscavam junto à justiça a sua comprovação. De qualquer forma, acreditamos na importância dessa documentação para o entendimento dos principais motivos que anulavam uma negociação de libertação, e até mesmo levavam forros de volta à escravidão.

Conforme se observa a partir desses dados, os conflitos que envolviam questões ligadas à liberdade são pouco representativos, se compararmos seus números com outros tipos de ações encontradas na amostragem para a segunda metade do século XVIII, pois perfazem apenas $0,33 \%$ do total desses processos. ${ }^{17} \mathrm{O}$ número reduzido pode ser explicado pelo fato de muitas situações terem sido resolvidas sem a interferência da justiça, ou de a maior parte das intenções de alforrias terem se consolidado. Mas, a existência dessas ações nos diz muito sobre o desencadeamento das negociações que buscavam a emancipação, e como isso pôde influenciar a relação senhorial e a vida do indivíduo que adquiria o status de liberto.

Pretendemos com a análise desses processos levantar alguns dos problemas encontrados por escravos e libertos no que tange à legitimação da alforria. Em vista das estimativas de manumissões concedidas na Mariana colonial, percebemos que as ações que serão apresentadas são restritas, ou seja, bem inferiores à consumação das concessões. Não obstante, elas nos reportam às principais regras que circundavam um processo de libertação, e, principalmente, nos permitem visualizar os entraves que marcaram a trajetória de vida daqueles sujeitos que buscavam a emancipação. Se, por um lado, as motivações econômicas poderiam influenciar os senhores a buscarem a justiça para resolver os conflitos com seus escravos, por outro a questão da manutenção da autoridade também esteve presente.

\footnotetext{
${ }^{16}$ MATTOSO, Ser escravo no Brasil, p. 180.

${ }^{17}$ Para Hebe Mattos, a ausência de uma "concepção plena de propriedade" contribuiu para a inexpressividade dessas ações no fim do período colonial, mas sua existência comprova a interferência no domínio senhorial, que se deu em nome do costume pelos representantes da justiça da administração portuguesa. CASTRO, Das cores do silêncio, p. 213.
} 


\subsection{O rompimento das coartações}

Algumas das ações encontradas referentes aos casos de alforrias onerosas foram movidas por senhores, que recorreram à justiça para tentar revigorar as condições negociadas em troca da libertação, principalmente no que diz respeito ao recebimento de valores atrasados, ou ao descumprimento de alguma cláusula mais específica. Os processos que se referem a réus coartados se originaram quase sempre por motivo de inadimplência com a quitação do valor referente à sua libertação.

A maior parte dos casos não traz o desfecho do processo, mas conseguimos perceber diferentes decisões da justiça quanto ao futuro desses escravos em processo de libertação. Há casos em que a redução se efetivou, mas também encontramos escravos que conseguiram manter o contrato com a ajuda de terceiros, como, por exemplo, de um fiador. Essas ações indicam que uma das dificuldades encontradas para um coartado manter em vigor seu contrato de libertação era a falta de pagamento. Se a negociação da liberdade significou uma conquista, essa não se mostrava tão legítima uma vez que havia condições específicas para concretizá-la, que estavam diretamente ligadas às decisões de seus senhores. A negociação não passava de uma tentativa que poderia dar certo, por vezes produzida a partir da coartação. Mas esses sujeitos, convictos de sua nova condição, lutaram na justiça tentando evitar o retorno à antiga condição de escravidão.

Quando estudada no quadro de recessões econômicas, a coartação apresentou significados diferenciados para senhores e seus escravos. Para os proprietários, foi associada às formas de reaver os custos despendidos com a compra e manutenção dos cativos. Para o escravo, representou uma importante oportunidade de alcançar a liberdade tão desejada, mesmo diante das dificuldades possivelmente enfrentadas com a escolha dessa opção.

As coartações foram representativas em algumas regiões de Minas Gerais no século XVIII, o que prova a sua aceitação tanto por parte dos escravos, como dos senhores. ${ }^{18}$ Consistia basicamente na compra da liberdade por um cativo, cujo pagamento deveria ser liquidado em parcelas estipuladas previamente pelo seu senhor. Essa forma de obter alforria não estava restrita a um grupo específico de escravos; "homens, mulheres e até crianças estiveram envolvidos nesse processo”. ${ }^{19}$ Depois de confirmada a negociação, o escravo

\footnotetext{
${ }^{18}$ PAIVA, Escravos e libertos, p.72-98. GONÇALVES, Andréa Lisly. As margens da liberdade: estudo sobre a prática de alforrias em Minas Gerais colonial e provincial. Tese de Doutorado, São Paulo: FFLCH/USP, 1999, p. 371.

${ }^{19}$ PAIVA, Escravos e libertos, p. 78.
} 
receberia um documento denominado "carta de corte” que comprovaria sua nova condição social.

A carta permitiria ao coartado certa mobilidade e a possibilidade de desenvolver atividades remuneradas que garantissem sua subsistência e ainda cobrissem as parcelas referentes à dívida adquirida com a libertação. Também teria função comprobatória nos casos em que divergências no decorrer do processo tendiam a mudar os rumos da tão sonhada emancipação, como nos que serão tratados a seguir. Qualquer ato de negligência poderia ser solucionado com o documento que continha as principais regras estabelecidas no momento da negociação. ${ }^{20}$ Tanto coartados como senhores se reportaram a esses registros nas situações em que tais conflitos geraram ações judiciais.

Há uma discordância na historiografia no que se refere ao momento de transferência da carta de corte ao escravo coartado. Laura de Mello e Souza parece associar esse documento à carta de liberdade, pois considera que o escravo somente seria possuidor desse registro a partir do momento que quitasse toda a sua dívida com a libertação. ${ }^{21}$ Eduardo França Paiva se refere a essas cartas como documentos muito raros nos processos que envolviam a alforria, por acreditar que geralmente não eram registrados em cartório. ${ }^{22}$ Andréa Lisly o vê como uma garantia ao proprietário do cumprimento do acordo estabelecido com o escravo. ${ }^{23}$ Apesar de não encontrar esses registros em seu trabalho, Carlo Monti parece definir melhor as funções desse documento.

O registro desses (...) servem para indicar a maior possibilidade de atuação de um escravo coartado, pois no início da manumissão uma carta de corte era entregue, possibilitando comprovar o processo de liberdade em futuras demandas judiciais, coisa essa impossível ao escravo que recebia a liberdade gratuita. Vale salientar que a carta de corte não encerrava o processo de liberdade, quando o pagamento estivesse quitado uma carta ou escritura de liberdade era redigida, ou mesmo a carta de corte podia ser copiada como escritura. ${ }^{24}$

\footnotetext{
${ }^{20}$ Marcos Magalhães Aguiar especificou os principais elementos que formavam o conteúdo do contrato, embora nem todos estivessem presentes nos "papéis de corte”: “o estabelecimento de período para a satisfação do valor, a regularidade e proporção dos pagamentos, as cláusulas de reescravização em situações de descumprimento do contrato e a exclusão da obrigatoriedade do escravo em satisfazer os jornais ao senhor durante a vigência do acordo”. AGUIAR, Marcos Magalhães. Negras Minas Gerais: uma história da diáspora africana no Brasil colonial. Tese de Doutorado, FFLCH/USP, São Paulo, 1999, p.21.

${ }^{21}$ SOUZA, Laura de Mello e. Norma e conflito: aspectos da História de Minas no século XVIII. Belo Horizonte: Editora UFMG, 1999, p. 158.

${ }^{22}$ PAIVA, Escravos e libertos, p. 81.

${ }^{23}$ GONÇALVES, Andréa Lisly. “Coartações na Comarca de Ouro Preto”. Pós-História, Assis, v.6, 1998, p.151.

${ }^{24} \mathrm{Em}$ nota, o autor faz referências a dois livros que demonstram que a carta de corte poderia ser registrada posteriormente como carta de liberdade, que são: Livro de testamentos, códice 61, p. 116, $1^{\circ}$ ofício; e Livro de Notas, códice 90, página 94, 1771. MONTI, Carlo. O processo da alforria; Mariana (1750-1779). Dissertação de Mestrado, FFLCH/USP, São Paulo, 2001, p. 154.
} 
O fator impulsionador dessa modalidade, conforme já abordamos, não guarda relações com a crise econômica ocorrida em meados do século XVIII, o que não implica que o fator lucro estivesse desvinculado de todas as negociações. Para Carlo Monti, também

Fica claro que com a diferença de valores pagos entre as liberdades registradas em cartórios e as consideradas em testamentos, e a diferença de valor dessas com a avaliação dos escravos feita nos inventários, podemos construir um forte indicativo de serem as alforrias onerosas, em especial as coartações, motivadas por um lucro significativo que os senhores podiam conseguir, muito maior do que se fossem vender o cativo no mercado. ${ }^{25}$

Uma indicação de que as questões econômicas estiveram associadas às concessões por meio de coartações pode ser percebida nos casos em que os senhores empregavam cláusulas no momento da negociação, como aconteceu com João Dias Ribeiro, que faleceu em 5 de março de 1757, deixando em seu testamento quatro escravos coartados, Felix Mina, João Ribibio, Lourenço Angola e André Mina. ${ }^{26}$

A condição para efetivação da libertação dos escravos era de que pagassem o valor de suas alforrias em parcelas semestrais durante quatro anos consecutivos, que variaram entre 300 mil réis, para Felix Mina e João Ribibio, 200 mil réis para Lourenço Angola e 100 mil réis para André Mina. ${ }^{27}$ Mas o falecido senhor parecia ter se resguardado da possibilidade de seus escravos não cumprirem as cláusulas da coartação. Em suas disposições testamentárias declarou que, na falta do pagamento, os mesmos deveriam ser “puxados” para o poder de seu testamenteiro para que pudessem ser vendidos. Dois anos após o falecimento de João Dias, que ocorreu em 27 de julho de 1759, os escravos ainda desfrutavam de plena liberdade sem cumprir com as cláusulas da coartação. Apenas João Ribibio e Lourenço Angola contribuíram com "algum ouro, o qual não se chegou a completar o primeiro pagamento"; os outros escravos não contribuíram com nenhum valor em espécie.

Condenando a negligência dos escravos e acreditando na impossibilidade de arcarem com o compromisso especificado pelo antigo senhor, o testamenteiro de João Dias Ribeiro, o Reverendo Domingos Soares, apelou à justiça para que os coartados fossem condenados a viver sob seu domínio, a fim de que a administração dos bens do testador pudesse prosseguir em pleno vigor. A justiça, em 26 de junho de 1760, deferiu seu pedido de embargo da coartação dos quatro escravos. Na sentença final, Felix Mina, João Ribibio, Lourenço Angola

\footnotetext{
${ }^{25}$ MONTI, O processo da alforria, p. 127.

${ }^{26}$ ACSM, Ação Cível, Códice 397, Auto 11132, 1759.

27 Por falta de maiores informações sobre esses escravos, não foi possível perceber o motivo que levou à variação de preço entre os mesmos.
} 
e André Mina foram julgados por servos por não efetuarem os devidos pagamentos despendidos com a libertação.

A ausência do senhor pode ter contribuído de forma definitiva para o cancelamento de um contrato de liberdade, uma vez que o papel do testamenteiro era apenas o de cumprir com as cláusulas especificadas, relativas à destinação de seus bens, impossibilitando, portanto, qualquer possibilidade de renegociação. Porém, também fica evidente que o fato desses coartados se apresentarem desfrutando de plena liberdade sem cumprirem com a principal cláusula da libertação, a quitação, foi o que determinou a abertura dessa ação.

O temor à perda da propriedade não se restringiu apenas à falta de pagamento; o medo de fuga também pode ser entendido como o elemento que moveu outra ação. Em 2 de janeiro de 1791, a escrava Ana crioula firmou um contrato de compra de liberdade com seu senhor, o morador do Inficionado, Diogo Cardoso de Souza. O prazo para o pagamento deveria ser de cinco anos, mas passado todo esse tempo, apenas parte do valor se encontrava quitado, a quantia de 27 oitavas, $1 / 4$ e 5 [vinténs]. Ao que tudo indica, desde que recebera a escritura de liberdade, ou o papel de corte, essa coartada se afastou da companhia de seu antigo senhor e passou a usufruir de sua liberdade, sem cumprir com as cláusulas da libertação. Essa informação foi dada por Diogo e confirmada por pessoas da região, que também testemunharam o contrato. ${ }^{28}$

Mas a situação se agravou em 1797, quando Diogo Cardoso passou a suspeitar que Ana crioula se afastaria daquela região. Acreditava que era "suspeita de fuga, tanto que costuma ocultar-se e andar erradia, e se distar vindo do sertão um seu Irmão por nome Simplício, talvez com o desígnio de a conduzir em sua companhia (...)”. ${ }^{29}$ Diante dessa suspeita, Diogo procurou a justiça e solicitou que a coartada fosse penhorada para que lhe fossem evitados maiores prejuízos. A justiça, acatando a petição do autor, citou a ré para a audiência de 31 de junho do mesmo ano, exigindo a apresentação de um fiador. Não conseguindo atender ao pedido da justiça, a ré acabou sendo presa, conforme certificação passada ao oficial de justiça Inácio Gonçalves de Souza, em 26 de julho de 1797:

(...) como ela não me deu dentro de seis horas, a segurei em um tronco, em casa de Domingos José Alves, e ele se obrigou a me dar conta dela dentro em vinte e quatro horas, para melhor procurar o seu Fiador, e dentro nas

\footnotetext{
${ }^{28}$ Duas dessas pessoas diziam ter presenciado a negociação, como Domingos Mendes de Souza e o Padre Francisco Paes Ferreira Coelho, que afirmou ter redigido o papel de coartação. O primeiro tinha 88 anos, vivia de minerar em Camargos; o segundo, com 71 anos, era morador de São Sebastião. Todas as testemunhas afirmavam que a ré "tratava sua vida como se fosse forra".

${ }^{29}$ ACSM, Ação Cível, Códice 359, Auto 9156, 1797.
} 
ditas horas me não entregou, e segurou-me que ela não se ausentava e a mandou para a cidade, e logo no mesmo dia a soltou (...).

Apesar de ter sido solta, Ana crioula não conseguiu se manter em liberdade: em 15 de fevereiro de 1799, foi condenada a voltar ao cativeiro. A acusação de fuga não foi novamente mencionada, mas sim acatada pela justiça a ponto de manter a ré sob uma das principais formas de coerção do cativeiro, o tronco.

A importância em cumprir as cláusulas de uma coartação, como vimos, não se restringiu apenas ao pagamento. Mais que uma determinação prática, a essas cláusulas era inerente a questão da dominação imposta pelo antigo senhor. Ana crioula permanecia afastada, sem cumprir com a quitação, mas, ao que tudo indica, debaixo de sua supervisão. A partir do momento em que houve risco de afastamento do lugar de alcance de seu domínio, o senhor tomou a atitude que reafirmava seu poder, algo que a maioria dos escravos temia: a sujeição ao tronco e conseqüentemente o retorno à escravidão.

Se maior parte das ações guarda relações com o prejuízo econômico por parte dos senhores, o temor em relação à perda de uma propriedade exigiu desses homens solicitações mais rigorosas à justiça. Satisfazer o pagamento do valor estipulado em um contrato não era a única imposição especificada por um senhor. Esses casos demonstram que outros tipos de transgressões, somados à falta de pagamento, certamente levariam escravos em processo de libertação de volta ao cativeiro, mesmo que ocorresse no período de vigência da quitação.

Embora a mobilidade espacial fosse um dos atributos da autonomia adquirida com a coartação, houve certa limitação quanto à sua extensão, que por vezes poderia se restringir apenas às adjacências de uma freguesia. ${ }^{30} \mathrm{~A}$ violação dessa condição associada à falta de pagamento mostrou-se também como um importante instrumento da autoridade senhorial para a anulação de uma manumissão.

Isabel de nação Angola foi coartada em acordo celebrado em $1^{\circ}$ de dezembro de 1788. ${ }^{31}$ As cláusulas especificavam que o pagamento de 110 oitavas de ouro fosse efetuado em parcelas mensais de duas oitavas num período de 6 anos consecutivos. Esse contrato determinava ainda que sua movimentação não estendesse às imediações das freguesias da Piranga, Sumidouro, São Sebastião, São Caetano e Furquim. Essas cláusulas mostram claramente a intenção de domínio que o senhor queria exercer sobre sua escrava, pois durante 6 anos ela teria que fazer pagamentos mensais, fato que certamente impediria o afastamento demasiado do local de cativeiro.

\footnotetext{
${ }^{30}$ GONÇALVES. As margens da liberdade, p. 155.

${ }^{31}$ ACSM, Ação Cível, Códice 262, Auto 6457, 1791.
} 
Passados 3 anos que o contrato havia sido firmado, Isabel estava vivendo no Taquaral, em Vila Rica, e, portanto, fora das imediações especificadas pelo senhor. Além disso, somente havia quitado a quantia de 17 oitavas e meia, referentes ao valor total estipulado, cujos recibos encontravam-se em seu poder, anexados à carta de corte.

Em decorrência do processo judicial, em 17 de agosto de 1793, as autoridades locais beneficiaram o antigo senhor, Domingos Ferreira da Silva, determinando que o coartamento, a partir daquele momento, não teria nenhum efeito por falta de cumprimento das cláusulas estabelecidas no contrato. Isabel então ficou sob o poder desse proprietário, mas não desistiu de sua liberdade. Em 3 de setembro de 1800, por meio do Capitão Leonel de Abrão de Lima, apresentou alguns documentos à justiça, dentre eles, duas petições, o papel de coartação e os dois recibos de pagamento mencionados no decorrer do processo. Ao ser ouvida em juízo, afirmou que seu senhor a matinha "em sua casa como escrava donde a pode privar de tratar do seu Direito”. Considerava injusta a atitude do mesmo por argumentar "haver-lhe pago não só com ouros as parcelas recebidas, por conta do coartamento, mas ainda os serviços e jornais (...) de anos".

O processo parece cessar a partir daquele momento, com um desfecho favorável à Isabel, pois consta nos autos que “(...) depois de pedida [a dita] vista passou o Autor carta de liberdade à Ré (...)”. ${ }^{32} \mathrm{O}$ desfecho desse processo não nos permite concluir os motivos que levaram o autor a conceder a libertação; apenas deixa transparecer que, mesmo diante da decisão judicial, Isabel, convicta de seus direitos, não desistiu de sua ação.

A maior parte dos coartados vivia distante de seus antigos senhores na vigência do processo de libertação, mas a liberdade plena somente ocorreria caso fossem cumpridas as ordens senhoriais. A alforria era vinculada a uma deliberação por parte do senhor, da mesma forma se procediam as condições que levariam à sua efetivação. Essas ordens pareciam muito particulares, ainda que houvesse algumas tendências em manter controle das atitudes e movimentos desses sujeitos. Um senhor sempre tinha um informante, alguém que "sabia por ver” ou "por ouvir dizer”, dos passos ou atitudes de seus escravos. No caso dos coartados, essa diligência parecia ainda mais eficaz. Essas escolhas tão particulares talvez tenham contribuído para que as definições se apresentem de maneiras divergentes na historiografia. Para alguns pesquisadores, os sujeitos assim definidos viviam em uma condição intermediária entre a escravidão e a liberdade, ou seja, o coartado não era escravo, mas também não era

\footnotetext{
${ }^{32}$ Pedir vista indicava obter os autor para vefiricação das informações nele contidas.
} 
liberto; essa situação se perpetuaria até a completa quitação do valor referente à sua libertação. $^{33}$

Eduardo França Paiva aproximou ainda a condição do coartado à do escravo de ganho, uma vez que ambos apresentavam certa mobilidade na sociedade a que pertenciam. Enquanto o coartado prestava serviços com o intuito de prover suas necessidades básicas e ainda adquirir pecúlio capaz de saldar as dívidas da alforria, o escravo de ganho simplesmente acumulava renda suficiente para que um dia pudesse adquirir sua liberdade. Algo que parecia positivo ao coartado e que o distanciava da condição de escravo era o fato de possuir pecúlio sem ter que prestar contas ao seu senhor. ${ }^{34}$

Mas ter autonomia para se deslocar e adquirir pecúlio nem sempre garantiu a consolidação da manumissão. É possível perceber que a falta de pagamento da coartação se deu pelas dificuldades que esses indivíduos enfrentaram a partir do momento que adquiriram nova condição. A árdua sobrevivência também poderia fazer parte da sua vida nesse momento, caso não conseguisse se fixar e trabalhar em um local. $\mathrm{O}$ ato de se estabelecer conjugava relações sociais e de trabalho. Não obstante, por vezes nem mesmo a profissão pôde garantir ao coartado a quitação do valor referente à sua liberdade.

Foi o que ocorreu com um oficial de sapateiro e outro oficial de alfaiate. Antônio Joaquim Lopes havia sido escravo de Ana Joaquina da Silva, moradora no Inficionado, e foi coartado em 64 oitavas de ouro em seu testamento. ${ }^{35}$ A quitação desse valor seria possível, “com a condição de trabalhar pelo ofício de sapateiro em companhia de José Lopes da Silva ou de Francisco de Paula”. O prazo para o pagamento era de parcelas anuais no período de 4 anos. Vencida a primeira parcela, Antônio pagou apenas parte da quantia. Segundo o testamenteiro da senhora falecida, esse escravo andava, "vadio, não se sujeitando ao trabalho determinado pela testadora”, informações confirmadas também pelas testemunhas do processo. Em contrapartida, o réu justificava em juízo as dificuldades de fazer sua defesa por motivo de ser “pobre e miserável”.

Domingos crioulo, oficial de alfaiate, também não conseguiu efetuar os pagamentos referentes à sua coartação, concedida em testamento de seu senhor, o Tenente Manoel Teixeira Ribeiro. ${ }^{36}$ Em abril de 1773 recebeu a Carta de Corte, mas parece ter ficado alheio ao cumprimento das cláusulas e depois à justiça, pois parecia estar ausente da cidade no decorrer do processo. Não há referências sobre o execício da profissão após a morte de seu senhor. O

\footnotetext{
33 SOUZA, Norma e conflito, p. 158. MONTI, O processo da alforria, p. 152. PAIVA, Escravos e libertos, p.77.

${ }^{34}$ GONÇALVES, “Coartações na Comarca de Ouro Preto.”, p. 156-157.

${ }^{35}$ ACSM, Ação Cível, Códice 250, Auto 6197, 1795.

${ }^{36}$ ACSM, Ação Cível, Códice 299, Auto 7209, 1774.
} 
único indício que temos é que, depois de receber sua Carta de Corte, ficou "tratando de sua vida”, sem cumprir com sua obrigação. Essa informação foi dada pelo testamenteiro de seu antigo senhor e por pessoas que testemunharam no processo. Depois das investidas do procurador, argumentando sobre a falta de compromisso daquele crioulo em um contrato firmado, em 23 de maio de 1774 a sentença favoreceu o Capitão Francisco Machado Magalhães, condenando Domingos a voltar para o cativeiro e ainda arcar com as custas do processo.

É importante salientar que a relativa ausência de normas legais metropolitanas quanto aos assuntos referentes à escravidão contribuíram de maneira decisiva para a adaptação e utilização de alguns artigos das Ordenações Filipinas no tratamento das ações de liberdade. Alguns deles foram utilizados pelo procurador do autor no caso demonstrado anteriormente e merecem destaque.

Para justificar a legalidade do pagamento em troca da obteção da liberdade, o procurador associou a alforria onerosa a uma compra efetuada a partir de um acordo entre o vendedor e comprador, na qual o senhor fazia o papel do primeiro e o escravo do segundo. Por esse prisma, a negociação parecia constituir-se de termos legais na medida em que fosse lida conforme o Título IV, do Livro IV das Ordenações Filipinas, que tratava da "compra e venda que fizerem, qualquer cautela, pacto e condição, em que ambos acordarem, contanto que seja honesta, e conforme a Direito”. ${ }^{37}$ Para que o acordo fosse válido, portanto, seria necessário que as partes cumprissem com todas as determinações firmadas. Caso isso não acontecesse, haveria todo um esforço em função de justificar a quebra do contrato por parte do autor, ainda no período de vigência do pagamento. ${ }^{38}$ Outros artigos são utilizados a partir desse momento; o primeiro diz:

É permitido nos contratos aos contraentes o estipularem neles as condições, e pactos em que acordarem, contanto que não sejam contra direito, e bons costumes. Mas uma das partes faltando ao cumprimento, não exige, portanto que a outra permaneça.

A partir desse ponto, o procurador argumentou que o autor não estaria obrigado a permanecer no Contrato do Coartamento, uma vez que o réu faltou ao cumprimento da principal condição, a quitação. Para justificar esse rompimento, se reportou ao Título XLIV, “Do contrato da Sociedade e Companhia”, que dizia: "E porque antes do tempo da

\footnotetext{
${ }^{37}$ ORDENAÇÕES FILIPINAS, Livro IV, p. 781-782.

38 Título 4 - Da venda de bens de raiz, feita com condição, que tornando-se até certo dia o preço, seja a venda desfeita; Título 44 - Do contrato da Sociedade e Companhia.
} 
Companhia ser acabado nenhum dos compradores se possa afastar dela, todavia em certos casos (...)”, sendo nessa situação, quando “(...) não é cumprida alguma condição, com a qual entrou na Companhia”. 39 Todos esses argumentos, mesmo não se referindo diretamente à questão da escravidão, foram empregados de maneira a impor ao coartado a antiga condição de escravidão.

Os casos analisados compõem um número reduzido de ações, mas, não obstante, mostram alguns traços comuns entre alforrias onerosas e coartação. Essa modalidade de alforria demonstrou ser suscetível a alterações no decorrer da libertação. Os conflitos entre senhores e coartados geralmente ocorriam nas circunstâncias em que a autoridade senhorial via-se “desafiada” por uma suposta ação negligente dos cativos que haviam adquirido certa autonomia com a coartação. Por um lado, houve clara motivação econômica, uma vez que os senhores se precaviam de um eventual prejuízo, indicando nos testamentos ou nas cartas de corte que, em falta do pagamento, os coartados não somente voltariam à condição de escravos, como igualmente teriam os valores até então pagos considerados como jornais e, portanto, jamais restituídos. Da mesma forma, o receio de dano por fugas os levou a estabelecer restrições no que se referia à mobilidade. Por outro lado, pode-se aventar que parte desses conflitos se associou às dificuldades de subsistência vivenciadas pelos coartados, fazendo com que contraíssem dívidas que acabavam impedindo a quitação do valor correspondente à libertação, levando-os assim de volta à antiga condição.

\subsection{A revogação de alforria por ingratidão}

Outro fator que determinou a anulação de contrato, ou de intenção de libertação, foi a ingratidão com relação ao senhor, pois receber uma doação implicava uma série de condutas à pessoa contemplada. Segundo Ordenações Filipinas, "se aqueles a que foram feitas forem ingratos contra os que lhas fizeram, com razão podem por eles as ditas doações ser revogadas por causa de ingratidão". ${ }^{40}$ Basicamente, as atitudes de ingratidão eram entendidas como agressões físicas, verbais ou negligência em relação a um senhor necessitado.

Manumissões concedidas em testamentos também foram alvos de anulações por ingratidão ao senhor, quando esse percebia o desrespeito à sua autoridade. Helena Moreira da Silva, preta forra natural da Costa da Mina, foi batizada na Igreja de Antônio Dias em Vila

\footnotetext{
${ }^{39}$ ORDENAÇÕES FILIPINAS, Livro IV, p. 829.

${ }^{40}$ ORDENAÇÕES FILIPINAS, Livro IV, p. 864.
} 
Rica, e, depois de alcançar sua liberdade pagando duas libras à sua ex-senhora, Rosa Maria preta forra, foi morar no arrraial da Passagem. Na ocasião da feitura de seu testamento, em 1774, declarava não ter filhos, mas um sobrinho chamado Antônio Moreira da Silva, filho de uma irmã que havia deixado em sua terra, o qual havia resgatado do cativeiro, pagando a seu proprietário, o Capitão João Ribeiro da Silva, morador de Congonhas, a quantia pedida. ${ }^{41}$

No curso da ação cível, Helena declarou não ter muitos bens, apenas possuir uma “morada de casas” e quatro escravos, dentre eles duas mães e seus respectivos filhos crioulos. Uma dessas escravas era Feliciana, a quem Helena afirmava ter criado como se fosse sua filha e por isso prometido livrá-la do cativeiro após sua morte. Mas a convivência entre ambas se mostrou conturbada após a escrava completar 12 anos, quando começou a se mostrar ingrata com sua senhora, descompondo-a e maltratando-a com pancadas. Esses foram os motivos que levaram Helena à instância judicial com intenção de reduzir sua escrava Feliciana crioula ao cativeiro. $^{42}$

Ao que tudo indica, por trás da intenção de anulação de uma libertação concedida havia a questão da honra e de reafirmação do poder senhorial suplantado pela ingratidão, pois essa situação poderia ter sido resolvida a partir da feitura de outro testamento, ou simplesmente de um codicilo.

A atitude de ingratidão da escrava se procedeu primeiramente pela frustrada tentativa de fuga com seu amásio, o crioulo forro Manoel de Souza. Feliciana foi capturada fora da Comarca e levada à casa de Domingos Soares, onde foi mantida sob correntes. Momentos mais tarde, sua senhora solicitou seus serviços quando convalescia de uma enfermidade em casa de Silvestre de Souza preto forro; mas não foi atendida pela escrava, que parecia viver "portas dentro" com o dito amásio, cuidando apenas de seus sustentos. Helena, contudo, não resistiu à doença que a acometeu, vindo a falecer antes mesmo da defesa da ré. A partir desse momento, seu sobrinho e herdeiro, Antônio Moreira da Silva, assumiu o caso.

Em resposta às acusações feitas pela autora, agora direcionadas ao seu sobrinho, a ré simplesmente as negou e argumentou que sempre tivera bom procedimento, jamais se ausentando do poder de sua senhora e a assistindo, principalmente, no momento de sua enfermidade. A acusação de concubinato também não procedia, pois suas relações com o crioulo Manoel de Souza eram restritas ao trabalho, e as de agressão à sua senhora era fruto do conluio de seus inimigos.

\footnotetext{
${ }^{41}$ ACSM, Testamento, Livro 51, 1774.

${ }^{42}$ ACSM, Ação Cível, Códice 290, Auto 7043, 1773.
} 
Diante desse impasse, restou à justiça solicitar testemunhas das partes interessadas no processo. Mas, a partir da nomeação, o procurador do autor contestou o juramento das testemunhas da ré, tecendo as redes de relações estabelecidas entre essas pessoas, que tenderiam a favorecê-la no julgamento da ação. O argumento que aparece repetidas vezes é o de que aquelas testemunhas eram "apaixonadas no vencimento da causa por parte da embargante”, a escrava Feliciana. O sentido “apaixonados” denota amizade e relações horizontais estabelecidas entre os mesmos. Simão José foi acusado de ser "casado com (...) Josefa da Silva, mulher parda que se trata com a embargada por comadre", por isso certamente tendia a favorecê-la. Joana da Silva, mulata, era “muito amiga da embargada (...)”. “Josefa da Silva, casada com Simão José Duarte, não só é comadre da embargada, como declarou ao costume, mas também muito sua amiga, (...) induzindo seu marido para também jurar a favor da embargada”.

Além da amizade, referências pessoais comprometedoras também foram citadas com o intuito de desmerecer algumas testemunhas, como "Clemência Fonseca é parda forra, e não deve prevalecer o seu juramento, pois é de tal qualidade, que sendo casada, largou o marido e está vivendo escandalosamente, e sendo comadre da embargada, o não declarou o costume”. E ainda "Manoel Moreira Guimarães foi amásio da testemunha Josefa da Silva, de quem teve dois filhos, e em respeito à mesma a quem ainda a favorece (...) e por isso juraria a favor da mesma, o que lhe insinuassem a dita, e a dita testemunha Josefa da Silva”.

Da mesma forma, o procurador da ré contestou as testemunhas do autor, mas com uma característica diferente das apresentadas anteriormente; algumas pessoas demonstravam malquerença com relação à Feliciana crioula por motivo de desavenças anteriores, mas não por sua má conduta e sim daqueles que a acusavam:

Ilário Ferreira Almada preto é inimigo capital da embargada, porque solicitando-a para atos desonestos, não quis condescender neles a embargada e por cujo motivo lhe concebeu um intratável ódio a dita testemunha, de sorte que por muitas vezes incitou a senhora que foi da embargada, para que a vendesse, só a fim de se vingar dela, e além disto, andou publicamente induzindo testemunhas para jurarem contra a embargada (...).

Outros, além de demonstrarem desafeto, foram acusados apenas de serem induzidos por pessoas mais próximas daqueles que queriam favorecer o autor: 
Ana Teixeira é uma preta, falta de verdade, e muito empenhada pelo autor (...) que a favor do mesmo, juraria tudo o que lhe insinuassem, por ser de fácil convenção, muito mais não se tratando com a embargada, por ser sua inimiga capital, e da mesma sorte da mão da mesma ré.

Jacinta Carvalha preta é inimiga declarada da embargada há vários tempos por pretender esta cobrar daquela certa quantia de uma obra que lhe mandou fazer, e, além disto, vive dependente do mesmo autor por morar em umas casas pertencentes ao dito, e para que este não lance fora, juraria tudo o que quisesse o embargante, por ser também a mesma testemunha falta de verdade, e muito capaz de jurar falso.

Alguns pareciam não ter relações diretas com Feliciana, mas com pessoas próximas a ela, e, portanto, passíveis de seram induzidas a jurar falso:

Joana Bandeira da Costa crioula é casada com Ilário Ferreira Almada, e foi induzida pelo dito seu marido a jurar falso contra a embargada (...).

(...) Maria Batista não podia jurar com verdade coisa alguma contra a embargada, por não saber do caso de que se trata, e só veio a jurar induzida pelo Autor embargante e o dito Ilário Ferreira.

(...) Antônio da Silva Correa preto foi induzido pelo Autor e o dito Almada para jurar contra a embargante, da qual é a mesma testemunha inimiga capital e com quem se não trata, pelo que é inatingível semelhante juramento.

Silvestre preto forro foi referido por ter sido favorecido pelo autor:

Silvestre de Souza preto sempre foi amigo particular do Autor embargante, e a que persuadiu à senhora que foi da embargada para que comprasse ao Autor e o tirasse do cativeiro em que se achava, e por isso, a favor deste juraria tudo que o mesmo quisesse, por ser seu empenhado, e pelo contrário inimigo declarado da embargada, com a qual se não trata.

Por fim, os motivos que fizeram todas essas pessoas jurarem contra a ré e a favor do autor, se reportava ao fato de serem "todas pretas, seus parciais, e da mesma facção com os quais come e bebe o mesmo Autor, e por ele induzidas para jurarem na presente causa, no que não há dúvida”.

Percebemos aqui que as pessoas indicadas pela ré foram caracterizadas pelo procurador do autor por serem de estrita relação de compadrio e amizade com a mesma; enquanto as do autor, não somente o poderiam favorecê-lo por motivo de retribuição a favores concedidos, como também eram consideradas inimigas da ré. Se o círculo de relações de Feliciana é composto basicamente por mulheres pardas, o de Antônio é formado por pretos 
que parecem interessados em ajudá-lo por motivo de retribuição de algum favor anteriormente recebido, ou seja, por redes de clientelismo montadas a partir de obediência e lealdade, que conseqüentemente asseguravam proteção e defesa. ${ }^{43}$ As testemunhas não foram alteradas, mas se acrescentaram outras para a inquirição dos conteúdos do libelo e desses embargos apresentados. A versão das partes foi confirmada por suas respectivas testemunhas, situação que provavelmente causou incertezas entre os responsáveis em julgar o processo; mas a ação parece ter cessado com a morte do Autor, quando a justiça liberou os autos "para [se tratar da habilitação]”.

Sabemos que os motivos que geraram esse processo, segundo os argumentos do autor, tenderiam a favorecê-lo perante a justiça, por se tratar de artigos definidos pela legislação, no Título LXIII, das Ordenações Filipinas. Entre elas, constam as injúrias proferidas em público, que causaram vergonha inicialmente à doadora; a agressão, que não causou ferimento, mas que pode ser entendida como uma intenção de injúria e desonra; e a negligência aos pedidos solicitados pela autora em momento de necessidade, quando a condição para ser alforriada era de que a servisse até o momento de sua morte. ${ }^{44}$ Mesmo se tratando de uma escrava, e não de uma liberta, como previa a legislação, acreditamos que maiores eram as razões jurídicas para que Felicina perdesse a oportunidade de se ver livre do cativeiro.

Mas a característica mais marcante desse processo é o momento da apresentação das testemunhas da ré e do autor, e conseqüentemente dos argumentos utilizados para tentar desmerecer o testemunho das pessoas que acreditavam poder favorecer a parte contrária. Em se tratando da ré, se por um lado fosse favorecida pelos testemunhos de pessoas com quem mantinha vínculos de compadrio e amizade, por outro, também seria prejudicada com a inquirição de pessoas tidas como suas “inimigas capitais”. Isso prova que, no período de cativeiro, as relações estabelecidas oscilavam entre conflito e concórdia. Ainda assim, percebemos que, na sociedade colonial, tanto escravos como libertos tenderiam a ter suas solicitações atendidas, desde que tivessem no seu círculo de relações pessoas de respaldo que pudessem favorecê-las.

Não foram somente os escravos que se viram em situação de perder os ganhos adquiridos com a negociação de sua libertação. As ações que envolviam a questão da liberdade, movidas por acusações de ingratidão, também estiveram associadas a casos de

\footnotetext{
${ }^{43}$ A concessão de alforrias era uma forma de obter clientes, pois estimulava o bom comportamento e promovia a lealdade e obediência do sujeito contemplado. GRAHAM, Richard. Clientelismo e política no Brasil do século XIX. Tradução de Celina Brandt. Rio de Janeiro: Editora UFRJ, 1997, p. 45.

${ }^{44}$ ORDENAÇÕES FILIPINAS, Livro IV, Respectivamente Parágrafos 1, 2, 4 e 8, p. 864-866.
} 
libertos ou pessoas que se intitulavam como tal. Esses foram acusados de injúria, constrangimento, incitação da desordem ou de forjamento de carta de libertação.

Os libertos envolvidos nas ações judiciais de redução ao cativeiro ou de liberdade eram basicamente pessoas que possuíam uma carta de alforria, mas cujos senhores pretendiam reavê-los por declarar que o documento havia sido passado não por "consentimento" e “aceitação”, conforme previa a legislação, ${ }^{45}$ mas sim sob alguma forma de coerção. Essa coerção geralmente partia de pessoas com quem tinham relações mais próximas, mas também de pessoas que exerciam certa influência na sociedade. Três casos envolveram esse tipo de situação, mas somente um pareceu apresentar decisão favorável a uma liberta.

Em janeiro de 1782, Luiza parda teve sua liberdade ameaçada a partir de um pedido de redução ao cativeiro feito por seu ex-senhor, o Alferes Antônio de Crasto Velloso, sob acusação de passar carta de liberdade sob pressão, seguida de ingratidão. ${ }^{46}$ Segundo o autor, a escrava iniciou uma série de requerimentos ao Sr. General D. Antônio de Noronha, sugeridos pelo Guarda Mor Bernardo Vieira Alpoim da Silva, e fundamentados em causas falsas, "a fim de ser liberta”. Esses requerimentos logo foram enviados ao Capitão Mor de Vila Rica, José Álvares Maciel, que, junto aos seus oficiais, constrangeram Antônio Velloso a passar carta de alforria à ré. O autor, portanto, "vendo-se consternado pelo mesmo Capitão e outros, e ameaçado deles, não teve mais remédio para evitar a violência, que com ele queriam praticar, e temor dela do que sujeitar-se, a mandar lavrar à Ré escritura em um dos Tabeliães de Vila Rica”.

Antônio Veloso também queria esclarecer à justiça que, ao invés de ser tratado com “reverência” e “respeito” por Luiza, era vítima de seus ultrajes e infâmias, pois ela andava acusando-o de ser "usurpador da fazenda de seu Tio, o defunto Sargento Mor Domingos Dias Veloso". Segundo o autor, Luiza, que tinha uma filha, também foi responsável pelo desaparecimento desta, além de incitar uma revolta de escravos ocorrida na Fazenda Paciência, que quase o matou.

Depois da contrariedade do libelo por parte da ré, foram ouvidas as testemunhas do autor. A partir da utilização dos termos "sabe por ouvir dizer”, "sabe pelo ver”, foram confirmadas todas as acusações feitas pelo autor à ré. Ao tratarem do ponto que se referia às pressões sobre Antônio Velloso por parte dos oficiais de Vila Rica, as testemunhas afirmaram

\footnotetext{
${ }^{45}$ Trata-se da abertura do Título LXIII, Das doações e alforrias que se podem revogar por causa de ingratidão, que diz: "as doações puras e simplesmente feitas sem alguma condição ou causa passada, presente, ou futura, tanto que são feitas por consentimento dos que as fazem e aceitação daqueles a que são feitas, ou do tabelião ou pessoa que por Direito em seu nome pode aceitar, logo são firmes e perfeitas, de maneira que em tempo algum não podem ser revogadas”. ORDENAÇÕES FILIPINAS, Livro IV, p. 863-864.

${ }^{46}$ ACSM, Ação Cível, Códice 318, Auto 7593, 1782.
} 
saber que o Guarda Mor Bernardo Vieira Alpoim fora o patrocinador dos requerimentos, vendo-se o autor "obrigado a passar carta de liberdade” para evitar uma ruína, "por temer a violência com que este ameaçava”. Outros dois depoimentos foram fundamentais para a hesitação quanto à veracidade desse artigo. O primeiro foi do Capitão José Pinto Madeira, de 41 anos, morador de Antônio Dias de Vila Rica, que, ao questionar o autor sobre o motivo que o levava àquela vila, ouviu o mesmo dizer que "era por respeito aos requerimentos que andava fazendo a ré (...)”. O segundo foi do Padre Antônio Ferreira de Araújo, de 43 anos, morador em Vila Rica, que dizia saber,

(...) por mostrar o Capitão José [Álvares] [Maciel] um requerimento da ré com um despacho do Excelentíssimo senhor Dom Antônio de Noronha, Governador que foi desta Capitania, para efeito de abrir preço à ré para sua liberdade, porém, não se lembra das [forças] para o dito despacho.

O Padre declarou ainda que,

(...) sabe pelo ver que indo ele testemunha como tutor à casa do dito Capitão Mor em uma noite a respeito da dita dependência da liberdade da Ré e aí, segundo sua lembrança, se achava o Guarda Mor Bernardo Vieira Alpoim protetor da Ré e com ele testemunha; e o tutor viram para casa do Tabelião José [Veríssimo] da Fonseca e aí passou [o autor] Carta de Liberdade a Ré pagando [ele] mesmo ao tabelião o emporte da dita carta e sabe ele testemunha que [o autor] por verdade do despacho do dito Excelentíssimo General é que passou a dita Carta à Ré, porém ignora as cláusulas do dito despacho.

(...) na ocasião em que ele testemunha foi em casa do Capitão Mor José Álvares Maciel [como tutor] não viu o dito Capitão Mor ameaçasse ao autor com prisões e só [sim] [o advertiu] prudentemente que abrisse preço para a Liberdade da Ré a que a dinheiro estava pronto ao que sempre repugnou o Autor dizendo que o preço não abria a sua escrava e que antes queria passar carta de liberdade gratuita visto ser violentado do que abri-lhe preço e como feito se passou a Carta do Tabelião José Veríssimo e passou a Carta de Liberdade gratuita do que ele testemunha como tal assinou segundo sua lembrança o que dele constara e mais não disse (...).

Diante desse depoimento, o procurador da ré, o Doutor Antônio da Silva e Souza, logo tratou de articular argumentos que pudessem reforçar o conteúdo dessas declarações. Afirmava ter a negociação, a princípio, a intenção de abrir valor referente à alforria, mas o autor concedeu gratuitamente "por se mostrar querer ser generoso" e assim, não recebeu dinheiro algum. No que diz respeito aos depoimentos sobre as injúrias e difamações da parte da ré, o procurador, além de negá-los, reportou-se ao artigo das Ordenações Filipinas, que dizia ser uma injúria grave e motivadora de vergonha a um doador aquela proferida em 
público, na presença ou ausência do mesmo, mas perante “alguns homens bons ${ }^{47}$. E quanto a isso não haveria provas, pois, “aonde está a infâmia, e injúria pública, os bons homens, que a presenciaram, a sua qualidade ofensiva, e vergonha do Autor, a prova legal (...). ${ }^{48}$

Em 30 de dezembro, a justiça proferiu sua sentença favorável à ré em virtude dos infundados argumentos de ameaças sofridas pelo autor, pois se tivesse ocorrido, o mesmo haveria de mostrar a "sua razão e justiça, com que o conseguiria todo o sossego". Outro fator de peso foram os testemunhos do Capitão José Pinto Madeira e do Padre Antônio Ferreira de Araújo, que provaram o autor não ter sido ameaçado, mas sim tratado com atenção e respeito pelo Capitão Mor. Perante a justiça, não haveria como se provar as acusações de injúria, uma vez que foram ditas pelas testemunhas em particular; em nenhuma das acusações houve mais de uma pessoa que as presenciasse. As palavras finais do Juiz de Fora Inácio José de Souza Rabelo foram: "julgo carecer o Autor de ação intentada, e pague o mesmo as custas dos autos”.

Diante da decisão judicial, o autor fez uma apelação ao Ouvidor Geral da Comarca e uma solicitação de citação da ré. Devido à ausência de informações, não sabemos o resultado das últimas solicitações. Mas, mais uma vez cabe ressaltar que o favorecimento do liberto se deu, por vezes, em função de boas relações sociais estabelecidas. Luiza somente adquiriu o status de liberta depois de receber a carta de liberdade, segundo o autor, passada sob pressão. Não se sabe se antes houve algum tipo de negociação ou promessa de libertação para que a mesma se julgasse como liberta, conforme também informou seu antigo senhor. O fato é que, na letra da lei, quando Luiza procurou seus intercessores, ainda era uma escrava, e que, por algum motivo desconhecido por nós, recebeu o auxílio desses terceiros.

Os indícios nos mostram que Luiza procurou pessoas que pertenciam ao círculo social de seu senhor, e que apresentavam certa autoridade sobre o mesmo, fazendo com que cedesse à manumissão. ${ }^{49}$ Isso fez com que o Capitão Mor Bernardo Vieira Alpoim fosse considerado como protetor e intermediador da sua libertação. Há aqui, portanto, forte indício de clientelismo que ultrapassa a relação senhor-escravo.

O mesmo ocorreu em outros casos, sem desfecho na instância local, mas que apresentam o envolvimento de pessoas vinculadas aos escravos favorecendo suas emancipações. Foi isso que ocorreu com o processo movido por Rita Maria Tavares, em

\footnotetext{
${ }^{47}$ ORDENAÇÕES FILIPINAS, Livro IV, p. 864.

${ }^{48}$ ACSM, Ação Cível, Códice 318, Auto 7593, folha 41.

49 Para Richard Graham, as redes de clientelismo ofereciam "proteção e garantia de favores a pessoas respeitáveis, (...) assegurando a lealdade de uma crescente clientela pela gratidão, quando não pela força”. GRAHAM, Clientelismo e política, p.40.
} 
outubro de 1771, querendo reduzir ao cativeiro a liberta Maria Angélica, com o propósito de se restituir os prejuízos gerados a partir da sua libertação ${ }^{50}$.

Rita Maria, estando ainda na Vila do Príncipe, lugar onde morava antes de se mudar para a cidade de Mariana, foi procurada pelo Padre José Antônio Pires, que tentou intermediar a libertação de Maria Angélica a pedido de seu pai, com a oferta de uma libra de ouro. Mas, acreditando na impossibilidade do pai dessa escrava levantar avultado valor "sem haver quem lhe emprestasse”, acabou não cedendo ao negócio, por temer o destino de uma escrava que,

(...) tinha criado com muito mimo, amor, e bom tratamento, e educando-a como se fora sua filha, e não a queria ver feita mulher dama, e ultrajada, por ser este o último fim, em que vem aparar semelhante qualidades de gentes depois de libertas.

Logo depois, procurada por outras pessoas “apaixonadas pela mãe” de Maria Angélica, a autora afirmou ter sido ameaçada e intimidada sob o argumento de que, não passando a liberdade de forma voluntária, “fariam com que por justiça fosse a Ré avaliada e pelo preço da avaliação Liberta”. Rita Maria Tavares temia ser o valor oferecido na negociação procedente do furto realizado pela mãe da ré, no período em que a mesma se encontrava guardando a casa do Tesoureiro dos Ausentes, o Sargento Mor Patrício da Silva Chaves.

A autora tímida e receosa, vivendo sem qualquer tipo de proteção, resolveu libertar Maria Angélica pelo valor oferecido de 200 mil réis, passando carta de liberdade em 24 de agosto de 1771, sob a condição de que a mesma deveria permanecer em seu poder até que seu pai, ou qualquer outra pessoa a seu pedido fosse buscá-la. Poucos dias depois, Rita Maria mudou-se para Mariana levando Maria Angélica, que logo deu início a uma série de atitudes de ingratidão e desobediência.

Depois de sair do poder da autora, carregando consigo todas as roupas pela mesma doadas, Maria Angélica, segundo a autora,

se portou com maior escândalo (...) nesta cidade, correndo às ruas dela de noite, procurando quantos homens topava, (...) e indo à casa de outros por modos de se lhe oferecer; dando por causa daquela saída, e dizendo o fazia porque a autora a maltratava com pancadas, tratando-a muito mal, e querendo que a Ré por força a servisse como sua escrava (...).

\footnotetext{
${ }^{50}$ ACSM, Ação Cível, Códice 303, Auto 7300, 1771.
} 
A autora se sentia injuriada por essas acusações e ainda por outras proferidas pela mãe da Ré, também sua escrava, que retirou suas roupas de casa e entregou a uma negra do Tenente Manoel da Costa Muniz com o intuito de fugir. Depois de informada sobre a tentativa de fuga, e de recuperados os pertences da escrava, Rita Maria mandou prendê-la em correntes, que não foram suficientes para detê-la. A escrava acabou fugindo na mesma noite, levando consigo o crioulo do Sargento Mor Patrício da Silva Chaves, que lhe servia de guarda. Na manhã seguinte, Maria Angélica procurou o Doutor Antônio da Silva e Souza para se queixar dos maus tratos sofridos pela sua mãe, que havia fugido do castigo e se encontrava com uma ferida nos olhos por ser tratada com pancadas.

Depois da fuga de sua escrava, Rita Maria permaneceu apenas com uma irmã da Ré, de pouco mais de 10 anos e um crioulinho de treze anos, tendo que executar por si mesma e por suas filhas, tarefas que jamais havia feito como cozinhar e lavar, e ainda recebendo de Maria Angélica “demonstrações de maior contentamento por ter posto a Autora e suas filhas naquela consternação”.

Por todos os motivos apresentados, a autora jurou a liberta de calúnia e seu o procurador solicitou à justiça que,

(...) nesses termos, conforme os de direito, deve a Ré ser condenada a servir à Autora como sua escrava, reduzindo-a para esse efeito ao cativeiro, à vista da desobediência, e ingratidão, e injúria que tem cometido contra a mesma Autora sua senhora com os fatos referidos e expressados no libelo e nas custas dos autos.

Esse processo termina com o depoimento de algumas testemunhas apresentadas pela autora, confirmando todas as acusações proferidas contra a Ré. ${ }^{51}$ Este também é um caso em que o senhor afirma ter passado carta de libertação por coação seguida de ingratidão; mas, o que mais chama a atenção é possibilidade de envolvimento de alguns membros da família na libertação da Maria Angélica.

A ausência do desfecho do processo não nos permite conhecer quem realmente foi o responsável por sua alforria, pois as informações dadas por Rita Maria se referem a um padre, José Antônio Pires, e ainda aos pais da mesma. Ou seja, trata-se de uma família, cujo pai não sabemos a condição social, a mãe tornou-se fugitiva do cativeiro no decorrer do processo, a filha mais velha Maria Angélica se libertou e a mais nova permaneceu como escrava na casa

\footnotetext{
${ }^{51}$ Esse caso também não tem desfecho, são apresentadas algumas inquirições das testemunhas da autora, confirmando sua versão sobre o caso; mas a partir da folha 14 aparecem testemunhos que não se referem a esse processo.
} 
de Rita Maria, conforme referências suas. A questão é: teriam realmente ocorrido libertações sob pressão tendendo a favorecer os escravos, e principalmente, os membros de uma família?

Segundo Kátia Mattoso, a experiência da alforria nunca foi uma experiência solitária, pois esse processo

Resulta de todo um tecido de solidariedades múltiplas e entrelaçadas, de mil confabulações, processos de compensações, promessas feitas e mantidas, preceitos, até mesmo de conveniência, reflexos e imagens mentais que constituem, no Brasil da escravidão, o quadro de uma sociedade que tem a sua própria concepção do "justo" e do "normal”. ${ }^{52}$

Diante da ausência de leis que garantissem a manutenção das famílias, impedindo, por exemplo, que os membros fossem vendidos ou libertados separadamente, é possível entender o esforço de terceiros nas negociações que tentavam favorecer essas pessoas. Mas essa idéia só pode ser levantada como hipótese devido à carência de informações quanto às relações existentes entre intermediários de uma alforria e o indivíduo a ser libertado.

É importante salientar que a intenção de favorecer alguém não necessariamente se basearia em relações como as de parentesco, pois a sociedade escravista colonial desenvolviase com base em relações assimétricas, nas quais as redes de clientelismo estabelecidas geravam subordinação e trocas mútuas entre desiguais. A circulação de informações sobre a vida alheia também era muito freqüente, conforme percebemos a partir de termos utilizados pelas testemunhas em seus depoimentos, como "sabe pelo ver”, "sabe por ouvir dizer”, "sabe por ser público e notório”. Dessa forma, os depoimentos das ações cíveis podem mostrar informações muito reveladoras sobre as relações desenvolvidas por libertos e seus antigos senhores, libertos e seus familiares, ou libertos e seus intercessores.

Carlo Monti fala de "relações vinculantes” ao tratar das modalidades de alforria em que havia certo distanciamento entre a concessão da liberdade e seu registro oficial. Nesse período surgia uma nova relação senhorial, caracterizada pela permanência do controle do senhor sobre o escravo a ser libertado, comprometendo a autonomia possivelmente adquirida com a manumissão. ${ }^{53}$ Para se tornar totalmente independente, era preciso se distanciar de seu antigo senhor.

Não sabemos se a liberta Josefa foi ou não favorecida por suas testemunhas, mas percebemos que sua circulação pela freguesia foi suficiente para que muitos a reconhecessem

\footnotetext{
${ }^{52}$ MATTOSO, Ser escravo no Brasil, p. 194.

${ }^{53}$ MONTI, O processo da alforria, p. 136. O autor cita um caso em que uma moradora do Inficionado alforriou sua escrava crioula gratuitamente em seu testamento, mas especificou que a mesma deveria viver agregada à sua casa.
} 
por tal condição, o que não impediu que tivesse sua liberdade contestada. Na audiência pública de 31 de agosto de 1761, proferida pelo Juiz de Fora Paulo de Souza de Magalhães, o advogado dos auditórios da cidade de Mariana, Domingos Gonçalves Fontes, solicitador de causas, entregou uma petição à justiça em nome de José de Morais de Sá, morador na Freguesia de Antônio Pereira. O autor solicitava que Josefa crioula fosse citada para falar de um libelo de redução ao cativeiro, por ter se ausentado da casa do autor "por meios duvidosos, falsos e menos verdadeiros”, ${ }^{54}$ se “intitulado como forra”.

José de Morais de Sá afirmava ter comprado Josefa crioula de João Batista Pereira, sem que houvesse nenhuma dúvida quanto ao seu direito de propriedade sobre a ré, mas a mesma "se ausentou de sua casa, e entrou a publicar que era forra sem na verdade o ser nem ter título que justo, ou válido seja de semelhante alforria”. Por meio de seu procurador, em 4 de setembro, José de Morais fez juramento de calúnia, mas a justiça não aceitou tal declaração e exigiu que o mesmo fosse feito pessoalmente, como efetivamente ocorreu no dia 15 do mesmo mês e ano.

Em primeiro de outubro, o procurador da ré, o Doutor João Dias Ladeira, ofereceu novas informações aos autos que contrariavam os argumentos do autor. Afirmava terem servido, Josefa e sua mãe, por muitos anos, em casa de José Dias como suas escravas, mas a ré se forrou depois de pagar ao mesmo a quantia de 239\$000, referente ao seu valor, “como consta de um papel que se acha lançado nas notas do Tabelião Manoel Varela, e reconhecido por ele”. O procurador ainda afirmava que Josefa não haveria de “articular o referido, se verdade não fosse e é rústica, e não havia de sair do cativeiro se o dito autor lhe não facultasse a liberdade que articulada fica, e ainda que presta, é de verdade e consciência”.

Sem delonga, no dia 2 de outubro, o procurador do autor respondeu às acusações, informando que José de Morais jamais recebeu ouro referente à libertação, nem mesmo passou carta de liberdade a Josefa. Afirmou ainda que o papel lançado nas notas era falso, e solicitou a apresentação desse documento à justiça, que logo foi acatada. A carta de alforria, apresentada, confirmava a libertação de Josefa em 26 de fevereiro de 1756, depois de pagar por sua coartação. Mas o autor reiterou que o documento era falso, pedindo exame para comprovação da veracidade da mesma. O auto de exame foi apresentado pelos tabeliães Manoel Varella da Fonseca e Custódio Pereira da Rocha, a partir da avaliação das assinaturas do autor que constavam na petição apresentada à justiça e na Carta de Liberdade, onde se constatou haver uma diferença muito grande entre as letras desses dois documentos.

\footnotetext{
${ }^{54}$ ACSM, Ação Cível, Códice 275, Auto 6760, 1761.
} 
A partir dessa afirmação, o procurador do autor entrou com uma série de argumentos para justificar a posição de seu cliente, como a afirmação de que não haveria como aquela carta ser verdadeira, uma vez que constava ser passada em 1756, período em que a ré se encontrava com apenas 13 anos de idade e, portanto, tratando-se de um momento em que ainda não tinha "agência, nem modo de adquirir a dita quantia”. Ao contrário, afirmava ser Josefa sua escrava, casada com outro escravo crioulo seu, com quem teve um filho chamado Manoel, nascido em dezembro de 1760 e depois abandonado pela mesma, mas logo assistido pelo autor que o levou à casa de Domingos Carvalho Rabelo, que o criava. Disse ainda ter cuidado da ré em suas doenças, "gastando avultada quantia nas curas”, sendo que não o faria se fosse liberta. Além disso, acusou a mesma de ser "ladina, esperta e inteligente”, e de ter fugido de sua casa de madrugada, atitude essa sem efeito se liberta fosse.

Mas o procurador da ré logo apresentou novos argumentos, justificando que o papel de liberdade era verdadeiro e passado pelo próprio punho do autor, depois de receber uma quantia em ouro, e de descontar os serviços prestados pela mãe de Josefa, como, por exemplo, a assistência despendida nos momentos de enfermidade do autor.

Diante desse impasse, a justiça procedeu ao pedido de apresentação das testemunhas das partes interessadas, gerando ainda mais conflitos entre as mesmas. Depois de apresentados os nomes, o procurador do autor, Domingos Gonçalves Fontes, contestou a autenticidade dos depoimentos das testemunhas apresentadas pela ré, por serem pessoas com relações muito estreitas, tendendo ao favorecimento da mesma no processo. Tratava-se de Manoel Martins de Sá, Sebastião da Costa Gusmão, João de Sá e João Pereira dos Banhos, considerados desejosos da vitória da ré sobre o autor. Os dois primeiros eram tidos como inimigos capitais de José de Morais de Sá, sendo o primeiro compadre da mãe da ré, e o segundo "novato na terra”, mas com dúvidas quanto ao recebimento das curas que foram feitas a Josefa em nome do autor. Além disso, fora vista por várias vezes freqüentando sua residência. João de Sá também apresentava favorecimento à embargada, mas João Pereira dos Banhos, “além de ser pardo e ter os defeitos que em direito são notórios, é par e amigo da embargada.”

Não há como sabermos mais a fundo que tipo de relações Josefa mantinha com as testemunhas por ela indicada, mas é certo que seus argumentos tenderiam a favorecê-la, como ocorreu na resposta às suas inquirições, e que levantaram informações antes não conhecidas sobre o caso. As testemunhas informaram que Josefa se libertou com a ajuda de sua mãe, que era forra, prestando serviços a José de Morais de Sá. Custódio Rodrigues Chaves revelou ter ouvido em uma conversa com o autor, nove meses antes daquela inquirição, “com suas 
próprias palavras”, que Josefa era liberta. O cirurgião Antônio Pires informou ter sido a mesma medicada por ele em 1759, período em que lhe havia mostrado a carta de alforria recebida pelo seu senhor depois de ser por ele molestada. Em decorrência disso, José e Josefa mantiveram tratos ilícitos, que se tornaram públicos, a ponto de serem advertidos pelo pároco da freguesia sobre a escandalosa relação. O casamento de Josefa com o escravo Inácio crioulo se deu, sobretudo, com o intuito de encobrir aquela situação. Mesmo depois do matrimônio, eles mantiveram tal ligação, sob a qual fora gerado um filho, que, segundo a ré, fora abandonado por orientação de José, temeroso das atitudes de seu escravo, caso constatasse não ser o pai da criança.

Infelizmente não contamos com a sentença final da justiça. As últimas informações do processo foram os depoimentos aqui comentados. Trata-se também de um caso em que o auxílio familiar contribuiu para a libertação. As divergências quanto ao reconhecimento da condição social de Josefa não passam pela questão da assimilação dessa informação pela sociedade, mas sim de formas de manipulação exercida pela pessoa com pretensão de ser favorecida. Apesar de nenhuma testemunha do autor mencionar os tratos ilícitos ocorridos entre o senhor e sua escrava, parece-nos certo o envolvimento de ambos. Isso talvez confirme o fato de Josefa não ter se ausentado do poder de seu antigo senhor, e, mesmo depois de liberta, ser sustentada e tratada por ele nos momentos de enfermidade.

É possível compreender a permanência de Josefa em seu local de cativeiro como uma dessas “relações vinculantes”, pois continuou usufruindo dos cuidados do seu antigo senhor. A partir do momento em que decidiu abandonar esse lugar, quebrando tais vínculos, passou a sofrer todos os tipos de acusação, como o de forjar sua carta de liberdade. Isso mostra que o rompimento de vínculos pode ter sido uma das causas que levou libertos a conhecerem a possibilidade de perder o reconhecimento de sua alforria. Se o envolvimento sexual representou uma forma de cativas se verem livres da escravidão, romper com essa relação poderia representar um risco à sua nova condição.

Alguns elementos eram imprescindíveis para a autoridade do senhor ou antigo senhor não ser contestada. Por um lado, era importante cumprir com as determinações econômicas por ele especificadas na negociação da manumissão, mas, por outro, era fundamental não romper com os vínculos criados. Mas o que nos parece ainda mais importante para assegurar a liberdade era a presença da carta de alforria, pois, uma vez produzida, reduziria as possibilidades de constestação. 


\subsection{A importância da carta de alforria.}

A dúvida sobre a condição social de uma pessoa negra, mulata ou parda na sociedade colonial mineira poderia gerar grandes transtornos e até o risco de ser reconhecida como escrava, conforme aconteceu com Josefa no caso supracitado. Também cabe lembrar de Francisco pardo forro, que foi tratado por escravo na ocasião da morte do seu pai em uma viagem a Portugal. Esse liberto foi alforriado em pia batismal e nunca dispôs de um documento que comprovasse seu verdadeiro status. Essa condição só era conhecida na cidade de Mariana por pessoas que o viram nascer e acompanharam seu crescimento, principalmente sua madrinha, uma das testemunhas que ajudou a comprovar esse fato na justiça. Apesar de ser considerado como tal, esse liberto não possuía um documento que indicasse sua verdadeira condição social. O mesmo pode ter ocorrido com outros escravos emancipados também no momento do batismo e que não dispunham de um registro de manumissão.

Conforme o princípio romano, a escravidão seguia o ventre; apenas no final do século XIX, com a Lei do Ventre Livre, foi concedida liberdade a todas as crianças nascidas de mães escravas. Antes desse período, somente seriam libertas caso o senhor as quisesse emancipar pela venda ou alforria gratuita. Em se tratando de uma mulher coartada, os indícios são de que o filho seria escravo, pois a libertação legítima ainda não havia sido alcançada, tal como demonstra o caso de Tereza de Faria Mota, que teve sua alforria ajustada por Gonçalo Gomes da Costa em março de $1748 .^{55} \mathrm{O}$ primeiro pagamento foi feito em 1749, mas Francisco da Silva Lira, seu senhor, não quis receber o segundo, argumentando estar a coartada "prenhe e que queria que o primeiro parisse", pois ainda não era forra e tinha a intenção de “cativar-lhe o filho”. Apesar de não termos conhecimento do que ocorreu com o filho de Tereza, é provável que tenha permanecido com seu antigo senhor, pois as condições que foram apresentadas lhe pareciam mais favoráveis. ${ }^{56}$

A princípio, os filhos de Vitória Cabra tiveram destinos diferentes do filho de Tereza. ${ }^{57} \mathrm{O}$ ajuste de sua liberdade foi feito por intermédio de Manoel Pereira dos Santos, intitulado como seu compadre, que também a ajudou a efetuar o último pagamento em agosto ou setembro de 1783. Acontece que esse ajuste foi feito em 1771 ou 1772, e, ainda que estivesse coartada, ela permaneceu sob o poder de seu proprietário, sendo assistida com tudo

\footnotetext{
${ }^{55}$ ACSM, Ação Cível, Códice 323, Auto 7699, 1751.

56 Mary Karasch afirmou que as crianças nascidas de mãe em liberdade condicional seriam consideradas escravas. O contrário somente ocorreria quando o senhor especificasse que a prole estaria isenta dessa condição ou quando registrasse a alforria. KARASCH, Mary Catherine. A vida dos escravos no Rio de Janeiro: 18081850. São Paulo: Companhia das Letras, 2000, p.462.

${ }^{57}$ ACSM, Ação Cível, Códice 279, Auto 6832, 1790.
} 
que lhe era necessário, sustento, medicamentos e parteiras para auxiliar o nascimento de seus quatro filhos: Fernando, Antônia, João e Ana. Depois de quitado o valor, portanto, Vitória queria seu documento de liberdade, mas também os de seus filhos, que foram batizados como escravos, conforme assentos de batismos registrados em 1774, 1777, 1779 e 1781, entregues à justiça.

Talvez em virtude de um pedido negado, Vitória procurou o General Luiz da Cunha de Meneses, que prendeu João Francisco e o obrigou a passar as ditas cartas de liberdade. Debaixo de prisão, foi levado por um Cabo dos Dragões chamado Manoel dos Santos Marques à casa de um tabelião de notas e,

(...) passando-se primeiramente carta de liberdade com algumas circunstâncias, para conservação da [justiça] do autor, não foi aprovada pelo dito Excelentíssimo General, e o mandou passar segunda sem cláusula alguma, com ameaças de perdição; e assim o praticou violentamente, contra a sua vontade, debaixo da mesma prisão, e acompanhado pelo sobredito cabo, mas sempre chamou e protestou o autor que nada fazia por sua vontade, mas sim obrigado pelo dito general, com quem não tinha partido algum, como dirão as testemunhas.

Diante do ocorrido, João Francisco recorreu à justiça em 1790 para tentar anular a liberdade concedida sob violência e pressão. Os filhos de Vitória encontravam-se com as seguintes idades: Fernando com 16 anos, Ana com 13 anos, Antônia com 11 anos e João com 9. Ao serem inquiridas as testemunhas apresentadas, essas confirmaram a versão do autor para os fatos, alguns alegando ainda que "sempre se queixou o autor pela violência e coação com que passou o dito Escritura”. Esse caso também trata de uma "relação vinculante” mantida depois de negociada a coartação, pois a versão dada pelo autor foi confirmada pelas testemunhas que queriam favorecê-lo no processo. Ao mesmo tempo, o caso denota o poder que o General Luiz da Cunha Meneses exerceu sobre João Francisco ao obrigá-lo a passar carta de liberdade a Vitória e seus filhos. Restaria apenas compreender quais foram os motivos que levaram um oficial das milícias de alto posto a favorecer uma coartada dessa forma.

Não dispomos de informações sobre a conclusão desse processo, mas a partir dele podemos pensar que essa situação tenderia a ser mais favorável aos filhos da coartada Vitória, uma vez que a possibilidade de anulação de uma escravidão seria muito mais remota quando a alforria deixava de ser uma promessa verbal ou redigida em testamento, e já se encontrava textualizada e registrada em cartório. Essas cartas não foram anexadas ao processo, mas 
sabemos que algumas das informações contidas nesse tipo de documento enunciavam a espontaneidade daquela atitude por parte dos senhores. Demonstravam também o desejo de que pessoa alguma, fosse testamenteiro ou herdeiro, pudesse desconsiderar aquela determinação, e que, a partir daquele momento, o manumitido faria o que quisesse de sua vida. $^{58}$

A liberdade recebida na infância e não registrada oficialmente gerava transtornos quando esses emancipados resolviam se afastar do local de onde tinham crescido. Anacleta crioula forra tinha tenra idade quando sua mãe se ausentou para a região de Minas Novas, ficando a mesma com uma irmã, que era escrava de Manoel Correa Rabelo e sua mulher. Anacleta cresceu na residência dos senhores de sua irmã, e depois de alguns anos resolveu se afastar de lá, quando esses passaram a publicar que sua liberdade era falsa, e que tinham a intenção de amarrá-la e castigá-la. Antes que o pior lhe acontecesse, Anacleta resolveu procurar a justiça para comprovar sua liberdade e ainda cobrar os jornais de seus serviços prestados a esse casal, no período em que ficou em seu poder. ${ }^{59}$

Francisca Maria do Sacramento, moradora em Furquim, nasceu em casa da proprietária de sua mãe, a liberta Graça de Barros preta forra. ${ }^{60}$ Era filha de Teresa de nação angola e João Dantas de Araújo. Ainda criança, Francisca foi trocada por outro escravo a mando de seu pai e depois levada em sua companhia, onde sempre fora tratada como liberta recebendo todos os cuidados e ensino. Depois de crescida e com filhos, João Dantas ameaçou vendê-los pelo valor de 500 mil réis, fato que a levou a Mariana para comprovar sua liberdade e evitar esse possível transtorno em sua vida.

Um ponto importante a ser observado é que muitos desses casos tratam de pessoas que passaram vários anos vivendo como libertos e somente depois de optarem pelo afastamento do local em que viviam, e conseqüentemente das pessoas a quem eram anteriormente subordinadas, tiveram sua liberdade contestada. Luiz Leite Pires era morador em São Sebastião e foi escravo de Domingos Leite, que fez venda de seus bens a Estevão Gonçalves Cruz. Esse senhor que o coartou parece ter logo falecido, deixando como herdeiro e testamenteiro José Martins Cruz. Nessa ocasião, Luiz ficou coartado em vinte oitavas de ouro, mas seguiu efetuando os depósitos especificados até que o herdeiro do seu antigo senhor se ausentou para Portugal. Luiz então passou a viver em sua liberdade por “oito ou nove” anos quando teve que comprovar sua condição na justiça. Isso se deu em virtude de uma denúncia

\footnotetext{
${ }^{58}$ ACSM, Cartas de liberdade anexadas às ações cíveis: Códice 244, Auto 6097 e Códice 340, Auto 8101.

${ }^{59}$ ACSM, Ação Cível, Códice 446, Auto 13962. Sem desfecho.

${ }^{60}$ ACSM, Ação Cível, Códice 274, Auto 6728. Sem desfecho.
} 
feita por um casal, Antônio Gonçalves e sua mulher, que argumentavam que o mesmo pertencia à herança de José Martins. Mas, ao que tudo indica, Luiz conseguiu manter sua liberdade, pois as acusações pareciam infundadas, uma vez que o antigo senhor não era falecido, e sim vivia casado na região para onde havia se ausentado. ${ }^{61}$

O fato de viver tantos anos em liberdade certamente contribuiu para que esses sujeitos recorressem à justiça para consumar o status adquirido. José Dias tinha sido escravo de Manoel João Dias, que o libertou em testamento, na condição de servir a seu irmão, José Dias Penido, enquanto fosse vivo. A escravidão assim procedeu por vários anos até que o irmão do falecido senhor disse que "o dava por forro, e que fosse tratar de sua vida para onde quisesse”. José Dias prosseguiu trabalhando e fazendo suas economias. Em certa ocasião, José Dias Penido solicitou uma quantia em dinheiro, que foi passada por sua mãe, pessoa a quem confiava o depósito de seu pecúlio. Depois de oito anos vivendo em liberdade, foi amarrado e castigado por José Dias Penido como se fosse seu escravo, sob as acusações de desobediência e de faltar com os serviços e jornais. Não sabemos se José Dias conseguiu provar sua liberdade, mas é importante ressaltar que foi ele quem procurou a justiça para tentar esclarecer o caso. Seria pouco provável que o fizesse sem que houvesse segurança para sustentar seu intento. $^{62}$

Mesmo que esses sujeitos passassem anos vivendo como libertos, não havia nenhuma lei que garantisse a permanência dessa condição perante a justiça. Se um senhor ou testamenteiro recorresse aos meios legais argumentando ter direito à posse de um ex-escravo, estavam dadas as circunstâncias para a abertura de um processo. ${ }^{63} \mathrm{~A}$ partir desses casos é possível perceber que a ausência de uma carta de alforria sempre denotou a incerteza sobre a verdadeira condição social de uma pessoa de cor na colônia. Ainda que fosse reconhecida como tal, isso não impediu que os vínculos criados com terceiros deixassem de expressar um caráter de subordinação e tentativa de dominação.

As tentativas de reescravização foram mais freqüentes com aqueles libertos que não tinham suas alforrias registradas em cartório. Em contrapartida, a presença de um registro de

\footnotetext{
${ }^{61}$ ACSM, Ação Cível, Códice 281, Auto 6876, 1795.

${ }^{62}$ ACSM, Ação Cível, Códice 262, Auto 6460, 1768.

${ }^{63}$ Por todo período colonial, somente o alvará de 10 de março de 1682 previa a prescrição da escravidão para um cativo que se encontrasse por 5 anos ou mais vivendo em liberdade incerta, mas ainda assim, se aplicava a escravos que viviam em quilombos, mais especificamente a Palmares. Trata-se da seguinte afirmação: “por não ser conveniente ao Governo político do dito meu Estado do Brasil, que, por mais do dito tempo, esteja incerta a liberdade nos que a possuem, não devendo o descuido ou negligência dele aproveitar os senhores”. GRINBERG, Keila. "Reescravização, direitos e justiças no Brasil do século XIX”. In: LARA, Sílvia Hunold e MENDONÇA, Joseli Maria Nunes. (Org.) Direitos e justiças no Brasil: ensaios de história social. Campinas, SP: Editora da Unicamp, 2006, p. 111. Cf. NEQUETE, Lenine. O escravo na jurisprudência brasileira: magistradura e ideologia no Segundo Reinado. Porto Alegre: Revista dos Tribunais, 1998.
} 
liberdade tampouco impediu esse tipo de situação. Mesmo estando em posse de uma carta de liberdade, alguns libertos tiveram problemas com herdeiros de seus antigos senhores que pretendiam conduzi-los ao cativeiro por insatisfação quanto à distribuição de heranças recebidas.

Apesar de se intitularem como libertos, Maria Mina, seus três filhos Antônio, Francisca e Ana, Maria Coelha crioula e seus três filhos Manoel, Ângela e João, foram acusados pelo herdeiro e testamenteiro do Capitão João Coelho Ferreira, então falecido, de possuírem "fantásticos títulos de Cartas de Liberdade”. ${ }^{64}$ O herdeiro em questão, o Reverendo Padre Manoel José Coelho, afirmava possuir escritura de compra de bens do falecido tio, entre os quais se incluíam esses ex-escravos, que foram apreendidos em primeiro de junho de 1799. Mas, ao que tudo indica, as afirmações do padre eram infundadas, pois todos aqueles escravos haviam recebido cartas de alforria do Capitão, e em seis delas fora declarada a dissimulação do reverendo na tentativa de induzi-lo a passar escritura de venda de seus bens. Essa afirmação, que merece destaque, contribuiu para que o procurador desses libertos na justiça afirmasse ser aquela escritura “nula e fabricada com notório dolo e malícia”.

\begin{abstract}
Declaro que por impertinência de meu sobrinho o Reverendo Padre Manoel José Coelho, lhe passei uma Escritura de todos os meus bens por me dizer que tinha vindo uma lei em que determinava os sobrinhos não poderem ser herdeiros e que assim, por minha morte iam os meus bens os ausentes e assim o fiz notando ele a Escritura como quis, sem considerar no mais e dizendo nela que eu recebera o importe de seis mil cruzados sem tal ser, e menos lho poder passar pela decrépita idade de mais de setenta e tantos anos e parecer a moléstia de vertigens e [poder ser em] prejuízo dos credores, e assim não poderá valer a coisa alguma sem embargo de ficar eu vocalmente senhor e possuidor dos ditos bens como estou a dispor deles como me parece enquanto for vivo, e por assim ser a mesma verdade (...).
\end{abstract}

A partir dessa declaração, esses libertos esperavam da justiça o reconhecimento de sua condição social, mas não contamos com o resultado desse processo. Seu final se dá com discussões que pretendiam definir a quem caberia arcar com a fiança e custas despendidas com a ação. O padre foi condenado pela instância local e pela Ouvidoria de Vila Rica, depois de recorrida. Por fim, fez agravo ao Tribunal da Relação do Rio de Janeiro, mas não sabemos qual foi o resultado.

O caso das pardas Margarida Martins Guedes e Rita Maria de Jesus ${ }^{65}$ também $^{2}$ iniciou com a execução dos herdeiros da antiga e falecida senhora, Ana Maria da Rocha, no

\footnotetext{
${ }^{64}$ ACSM, Ação Cível, Códice 340, Auto 8101.

${ }^{65}$ Ação Cível, Códice 244, Auto 6097, 1797.
} 
ano de 1784, por Francisco da Costa Guimarães. Essa senhora parecia ter contraído uma dívida de 232\$141 réis com Francisco, então cobrada em execução judicial do dia 13 de fevereiro de 1784. Nessa execução, houve a determinação de que na falta do pagamento, os bens da devedora deveriam ser penhorados, conforme parece ter ocorrido, e entre eles constavam as duas pardas.

Em 22 de abril de 1795 Rita e Margarida foram penhoradas, mas não sabemos qual foi o tratamento dispensado a elas depois do ocorrido. Naquela ocasião, Margarida Martins Guedes já se encontrava forra, pois fora vendida pela sua antiga senhora a seu pai, João Martins Guedes, com a obrigação libertá-la, conforme o fez em 04 de maio de 1778,

(...) sem constrangimento de pessoa alguma a forro por ser minha filha, fica sendo de hoje para todo sempre como se forra nascera da barriga de sua mãe, e não poderá em tempo algum duvidar, nem meus herdeiros, testamenteiros ou procuradores, e poderá a dita minha filha fazer o que seja seu gosto de hoje em diante, como forra que fica sendo (...).

Rita Maria se encontrava na condição de coartada desde julho de 1792, pagando em dia todas as prestações referentes à sua liberdade. $\mathrm{O}$ valor estipulado pela sua antiga senhora foi de 130 mil réis, para serem satisfeitos em 5 pagamentos iguais e anuais. Restava apenas um pagamento, mas Rita demonstrava estar pronta para fazê-lo por meio de fiadores, Maria Joaquina do Nascimento e Antônio Martins Guedes. Diante da justiça também foi necessária a apresentação de um fiador por parte das embargantes para que se pudesse dar prosseguimento ao processo e as mesmas pudessem manter a posse de suas liberdades. Para tanto, em 21 de julho de 1797, foi apresentado o Capitão Joaquim da Silva, morador no termo de Mariana, pessoa de conhecida abonação. Houve reconhecimento da libertação de Margarida, mas Rita continuou penhorada.

Esse caso mostra a situação embaraçosa em que muitos libertos e coartados se encontraram após a morte de seus antigos senhores. Era mais fácil reconhecer a liberdade daqueles que dispunham de uma carta de alforria, que, no entanto, não estavam isentos de reviver situações que cabiam apenas a um escravo, como castigos e prisões. Não bastava a posse de um documento de liberdade, ou a comprovação da legalidade de um processo de libertação, havia sempre pessoas empenhadas em reaver a liberdade daqueles que acreditavam que ainda lhes eram subordinados. Os principais interessados em fortunas deixadas pelos falecidos abastados criaram situações que levaram forros a reviver momentos que os aproximavam da escravidão. Até mesmo famílias inteiras estiveram envolvidas em ações judiciais com o intuito de comprovar a condição conquistada. 
A partir da análise dessas ações, percebemos que tanto os libertos sob condição como os forros vivenciaram a possibilidade de voltar à servidão. Os escravos que buscavam se libertar por meio de modalidades de alforria pagas, em especial as coartações, foram os mais sujeitos à ameaça de reescravização. Uma das razões para tanto foram as restrições sofridas por esses indivíduos a partir do momento que se afastavam do domínio do antigo senhor. A falta de pagamento foi o principal motivo para as ações de redução ao cativeiro, mas o descumprimento de alguma cláusula estabelecida pelo antigo senhor também representou um peso nos argumentos daqueles que moviam esse tipo de ação. A busca pela instância judicial se deu, em grande medida, como forma de tentar resolver os conflitos ocorridos a partir da autonomia adquirida pelo liberto sob condição. A legislação se mostrou restrita nesses casos, mas houve certa adaptação, por parte dos advogados, de artigos da legislação que não eram próprios ao assunto, no sentido de favorecerem os senhores temerosos de serem lesados a partir descumprimento de suas determinações.

Se as ações que envolviam falta de pagamento dificilmente eram derrotadas, por trazerem maiores garantias aos senhores, aquelas geradas por motivo de desrespeito se mostraram muito mais intricadas, mesmo diante de uma maior adequação à legislação. ${ }^{66}$ Nos poucos casos encontrados, a concessão da alforria e a sua manutenção eram pautadas pelo princípio “de fazer por merecer”, ou seja, pela constante reverência e respeito à figura do senhor. O comportamento deveria ser sempre de obediência, humildade, fidelidade e reverência, perpetuando-se para o resto da vida, principalmente para aqueles libertos que permaneciam nas proximidades do seu local de cativeiro.

Nos casos de conflitos, esses libertos foram acusados de injúria, agressão, falsificação de documento, mas também tiveram os intercessores da negociação de suas alforrias acusados de coerção. Os réus, enfim, recorrerem às pessoas que sabiam poder favorecê-los, como aqueles com quem tinham vínculos de sangue, compadrio, amizade, ou então relações ainda obscuras para nós. Apesar da manutenção do poder do senhor sobre o libertando ou até mesmo liberto ter sido uma realidade, essa autonomia poderia deixar de ser contestada na medida em que houvesse interferência de pessoas mais poderosas que o proprietário.

Os senhores marianenses, com base em relações costumeiras, concederam liberdade a seus escravos, mas não deixaram de apregoar sua autoridade. Os cativos e libertos, por sua

\footnotetext{
${ }^{66}$ Referimos-nos aqui ao Título LXIII das Ordenações Filipinas, Das doações e alforria que se podem revogar por causa de ingratidão. ORDENAÇÕES FILIPINAS, Livro IV, p. 863-864.
} 
vez, perceberam essa coerção, mas acima de tudo, compreenderam que, com a articulação de laços a partir de relações interpessoais, fossem elas hierárquicas ou não, alcançariam o maior objetivo que era o da manutenção da libertação e ainda de inserção naquela sociedade. 


\section{CONSIDERAÇÕES FINAIS}

As tranformações sócio-econômicas decorrentes da descoberta do ouro na Mariana colonial envolveu a ocupação da mão-de-obra de africanos e crioulos na mineração e também nas mais diversificadas funções de que necessitava aquela sociedade. A escravidão nessa cidade, assim como em outras regiões urbanas e auríferas, gerou condições que possibilitaram aos cativos a conquista da liberdade. Mesmo que o acesso à manumissão fosse restrito à maior parte dos escravos, isso não impediu que a população livre de cor tomasse proporções consideráveis ao longo do século XVIII.

A prática da alforria foi representativa na cidade e vários caminhos conduziram a tanto. Definir uma tendência para os motivos que impulsionavam as manumissões não nos parece adequado, pois as modalidades foram diversificadas, seguindo, por vezes, razões bem particulares. Foram associadas a fatores econômicos, a formas de se desfazer de um escravo incapacitado ou de crianças, mas também por gratidão e bons serviços prestados. Em síntese, tratava-se da vontade do senhor em dispor de um bem, fosse gratuitamente ou por meio de contrapartida onerosa. Salvo raras exceções em que esses tentavam reaver o cativo argumentando ter passado carta de liberdade por coação, a negociação de fato somente iniciaria e teria prosseguimento a partir do consentimento do proprietário.

Nesse sentido, a alforria nos parece mais um reforço do poder senhorial e conseqüentemente da escravidão, do que necessariamente uma negação da instituição. $O$ período entre os primeiros esforços de libertação e sua legitimação poderia durar anos e havia uma série de princípios reservados a quem estivesse sujeito a esse processo. Aqueles que tentavam se emancipar a partir das modalidades condicionais estavam mais propícios às investidas de reescravização quando alguma queixa lhes era direcionada. Mas alguns direitos e proteções também acompanhavam a trajetória de um emancipado.

A transição da escravidão para a liberdade representou um dos momentos de maior importância na trajetória de vida de um cativo, pois tratava da mudança de status social, da legitimação de um ideal construído no interior daquela sociedade e almejado pela maior parte dos escravos. Além disso, era o momento em que passavam a desfrutar de algumas concessões anteriormente interditadas, como as de mobilidade, direito pleno à família e propriedade. 
O escravo que tentava se emancipar a partir de alforria condicional tinha o acesso à mobilidade especificado pelo patrono, podendo haver ou não restrições quanto ao limite de deslocamento, dentre outras condições, conforme observamos nessa pesquisa. Mas ao liberto nenhuma condição era colocada. Ainda que optasse por permanecer no local onde vivera em cativeiro, ou mesmo como agregado, era de seu livre arbítrio a locomoção para onde e quando quisesse. Em uma sociedade escravista, qualquer pessoa negra ou mulata que se aventurasse por territórios alheios poderia ser confundida com um escravo, caso não dispusesse de uma carta de liberdade. Na Mariana colonial percebemos que, ainda que algumas pessoas fossem reconhecidas como forras, parecia sempre pairar uma dúvida com relação a outras.

A carta de alforria, então, era um documento fundamental a qualquer emancipado que pretendesse se afastar do local onde tinha sua condição social reconhecida. Vimos que os forros que tiveram sua trajetória social marcada pela possibilidade de retornar à escravidão viveram muito tempo em liberdade, mas sem um documento que comprovasse sua verdadeira condição. Os casos de contestação de uma carta se davam em ocasiões mais específicas como cobranças de herdeiros de senhores falecidos, ou por motivo de ingratidão e argumentação de ter passado o documento sob pressão. No entanto, a possibilidade de reescravização se tornava mais remota quando havia o registro que comprovasse a libertação.

É certo que quando não envolvesse questões de heranças, a contestação da liberdade teria maiores chances de ocorrer com um liberto que não possuísse residência fixa do que com aqueles estabelecidos na cidade, com moradias próprias e ocupação. Trabalhamos com informações de que escravos se libertaram e permaneceram na cidade até a morte, mas também há indícios de pessoas de outras localidades que acabaram se fixando e falecendo na região.

É possível perceber que a constituição de famílias para alguns libertos se deu ainda sob o jugo da escravidão, mas não faltaram esforços dos parentes emancipados para libertar suas esposas, seus maridos, filhos ou irmãos escravizados. Os forros também viveram sozinhos, sem qualquer referência a cônjuges ou familiares; outros, porém, casaram-se tardiamente e acabaram não gerando prole.

A experiência da liberdade foi marcada pela importância das relações interpessoais, pois o ambiente urbano encurtou ainda mais a distância entre pessoas de diferentes segmentos sociais. A constituição de família e as irmandades também funcionaram como espaços de agregação social, de conotações basicamente assistencialistas e espirituais. Mas foram as relações cotidianas que acabaram por inserir o liberto na hierarquização social e definir as 
diferentes experiências aqui analisadas. Nas ocasiões em que os libertos ou supostos alforriados se envolveram em demandas judiciais, as pessoas que por eles intercederam não necessariamente eram indivíduos da mesma categoria social, ou de identidades étnicas afins. Apesar de não serem claras as relações estabelecidas com aqueles que os favoreceram, é possível afirmar que parte delas foi configurada pelos vínculos clientelísticos presentes naquela sociedade hierarquizada.

A obtenção de propriedade foi uma realidade que os libertos conheceram em Mariana na segunda metade do século XVIII: eles valorizavam imóveis, trastes de casa, jóias, e, sobretudo, escravos. Tornar-se proprietário de escravos era uma forma de se afastar da experiência do cativeiro e de legitimar o status alcançado. Mas, se obtenção da liberdade era uma tarefa difícil, a compra de um cativo parecia ainda mais complexa. Se considerarmos a posse de escravos a partir das informações deixadas por libertos que legaram posses, tenderemos a pensar que a propriedade escrava foi muito disseminada entre as pessoas desse segmento social, mas, ao olharmos para os óbitos de escravos de pessoas que pertenciam a essa categoria social, percebemos que isso não foi a regra.

Ainda que os libertos tivessem acesso a bens, foi possível notar que seus legados se equiparavam aos das pessoas que possuíam posses mais modestas. As heranças mais avultadas ainda foram localizadas em registros de pessoas que viviam em freguesias pertencentes à cidade, e que tinham funções possivelmente voltadas para a mineração ou produção de bens de consumo. As demais se restringiam a peças de uso doméstico, vestuário e poucos escravos. Os objetos deixados evidenciam a adoção de práticas da classe dominante, mas também foi possível perceber a presença de artigos como jóias, que, além de servirem como adornos, tinham significados mais particulares de cunho religioso.

Adquirir posses não necessariamente guardou relações com bonança econômica, haja vista que não somente bens como imóveis ou escravos puderam ser adquiridos por meio do crédito. O principal ponto a ser observado é que os libertos estabeleceram negócios com as mais diferenciadas pessoas, fosse com o objetivo de garantir a sobrevivência, ou buscando investimentos diversos. Adquirir um bem, contudo, geralmente indicava endividamento, que por vezes poderia se acentuar a ponto de nem todas as transações comerciais serem efetivadas.

Não sabemos em quais momentos de suas vidas os libertos se viram diante da pobreza, pois não dispomos de informações de períodos diferenciados referentes a um mesmo sujeito, mas pudemos constatar mais precisamente esse fato no momento da morte. Por se tratar de um universo em que o endividamento era corriqueiro, levantamos a hipótese de que 
as dívidas contraídas poderiam levar um indivíduo à pobreza, pois não raro essas negociações acabavam nas instâncias judiciais e tendiam a desfavorecer o princípio ético da honra, tão caro a toda a população, mas principalmente aos egressos do cativeiro que buscavam se estabelecer na sociedade.

A condição de pobreza apresentou conotações diferenciadas, mas, de maneira geral, estava associada ao estado de nada possuir ou de viver do auxílio de terceiros, a partir da impossibilidade que alguns encontravam de assumir uma ocupação. Ainda que a historiografia tenha apontado para a desclassificação social dos libertos tendo em vista a privação de recursos, em nossos registros foram raros os casos em que eram tratados dessa forma; pelo contrário, eles se mostraram totalmente situados na dinâmica econômica e social na cidade de Mariana, ainda que apresentassem realidades econômicas diferenciadas.

A distinção econômica entre libertos foi um dos fatores que marcou suas trajetórias de vida na Mariana colonial. Adquirir posses, sem dúvida, demarcava uma posição social. No entanto, também foram constatadas situações de pobreza e a possibilidade de reescravização. Isso nos remete a pensar que o elemento definidor central das trajetórias sociais dos egressos do cativero não está associado à possibilidade de acúmulo de posses ou de ascensão econômica, mas sim à mudança de status. Em uma sociedade marcada pela cisão entre a escravidão e a liberdade, importava menos as restrições que enfrentariam com a manumissão: o objetivo principal era, sem sombra de dúvidas, o de alcançar a liberdade. 


\section{FONTES E BIBLIOGRAFIA}

1. Ações Cíveis - Redução ao Cativeiro, Ação de Liberdade e Outras $-1^{\circ}$ e $2^{\circ}$ Ofício (Arquivo da Casa Setecentista de Mariana).

Códice (Auto, Ano):

244 (6097, 1784), 250 (6210, 1758), 250 (6197, 1795), 250 (6203, 1759), 262 (6457, 1791), 262 (6460, 1768), 262 (6474, 1768), 264 (6531, 1757), 275 (6760, 1761), 276 (6779, 1755), 279 (6832, 1790), 281 (6876, 1795), 283 (6916, 1782), 290 (7043, 1773), 290 (7052, 1795), 299 (7209, 1774), 303 (7300, 1771), 303 (7305, 1766), 308 (7387, 1791), 308 (7394, 1756), 313 (7490, 1775), 316 (7550, 1768), 317 (7569, 1769), 318 (7593, 1782), 323 (7699, 1751), 335 (7969, 1766), 336 (7970, 1796), 337 (7994, 1766), 340 (8101, 1799), 354 (8883, 1799), 359 (9156, 1797), 365 (9510, 1754), 383 (8381, 1779), 396 (11110, 1800), 397 (11132, 1759), 397 (11141, 1758), 400 (8762, 1792), 433 (13236, 1778), 446 (13962, 1760), 453 (14337, 1751), 479 (10679, 1798), 510 (17728, 1789), 617 (23898, 1763).

\section{Ações Cíveis - Cobranças - $1^{\circ}$ e $2^{\circ}$ Ofício (Arquivo da Casa Setecentista de Mariana).}

\section{Códice (Auto, Ano):}

274 (6724, 1767), 296 (7145, 1752), 293 (7093, 1793), 301 (7255, 1782), 303 (7302, 765), 304 (7313, 1771), 328 (7806, 1771), 347 (8470, 1792), 362 (9285, 1764), 364 (09442, 1769), 367 (9585, 1798), 371 (9817, 1766), 381 (10284, 1758), 382 (10338, 1766), 385 (10447, 1791), 390 (8540, 1757), 393 (10911, 1752), 397 (8704, 1776), 397 (11145, 1759), 401 (11381, 1756), 412 (12000, 1760), 413 (8995, 1774), 413 (12079, 1762), 417 (12288, 1772), 425 (12748, 1778), 442 (13712, 1753), 444 (13865, 1758), 450 (9728, 1757), 452 (9791, 1750), 453 (14326, 1783), 454 (9850, 1778), 454 (9888, 1764), 460 (10095, 1763), 464 (10292, 1763), 465 (10308, 1769), 468 (10384, 1769), 469 (15261, 1752), 498 (16943, 1762), 503 (17259, 1767), 511 (17749, 1759), 528 (18720, 1791), 540 (19481, 1769), 553 (20290, 1783), 568 (21073, 1785), 579 (21643, 1751), 595 (22569, 1784), 600 (22881, 1783), 613 (23665, 1764), 621 (24139, 1758), 622 (24188, 1751).

3. Registros de óbitos (Arquivo Eclesiástico da Arquidiocese de Mariana) - 1719-1802. Prateleira Q, Volumes: 10-11, 13-18. 


\section{Testamentos (Arquivo da Casa Setecentista de Mariana).}

\section{Nome (Livro, Ano)}

Ana da Conceição $(41,1791)$

Ana Lopes (60, 1756)

Ana Maria Pinto $(57,1783)$

Ana Maria Pinto $(57,1779)$

Ana Moreira Silva (58, 1766)

Antonio Alves da Silva $(55,1769)$

Antonio da Costa Soares $(54,1778)$

Antonio Pereira da Silva $(69,1762)$

Antônio Pinto Homem $(46,1789)$

Antônio Teixeira da Costa $(51,1772)$

Catarina $(68,1765)$

Catarina Correia $(54,1777)$

Catarina da Costa $(56,1786)$

Catarina da Mata $(52,1776)$

Catarina da Silva $(59,1760)$

Domingos Dias Penido $(64,1754)$

Francisca da Conceição $(57,1782)$

Francisca Ferreira Machado $(46,1791)$

Francisco Alves Coutinho $(66,1789)$

Francisco Pinto $(57,1780)$

Helena Moreira da Silva (51, 1774)

Izabel Fernandes $(51,1773)$

Izabel Pereira $(59,1759)$

Joana Ferras $(71,1751)$

Joana Pais Pena $(50,1756)$

João Pereira da Cunha $(51,1771)$

José de Deus $(53,1760)$

José Gonçalves $(41,1791)$

José Luiz $(53,1760)$

Josefa da Mota $(58,1767)$

Josefa da Silva $(47,1783)$

Josefa de Oliveira $(60,1755)$

Josefa Lopes (51, 1773)

Josefa Maria da Silva $(57,1779)$

Josefa Martins $(67,1754)$

Josefa Rodrigues da Silva $(54,1778)$

Julião do Couto Ribeiro $(54,1776)$

Lauriana de Souza $(57,1782)$

Luiz Gonçalves $(61,1792)$

Luiza dos Santos $(69,1761)$

Luiza Ferreira Vale (55, 1769)

Luiza Maria $(45,1797)$

Luzia da Costa $(64,1754)$

Manoel Carvalho $(71,1751)$

Manoel da Silva $(56,1786)$

Manoel de Souza $(66,1788)$

Manoel Lopes $(52,1776)$ 
Marcela dos Reis $(64,1753)$

Maria da Costa $(67,1754)$

Maria da Silva $(71,1751)$

Maria de Meira $(71,1751)$

Maria Gomes Chaves (57, 1780)

Maria Pinto $(68,1764)$

Mariana da Silva $(60,1755)$

Miguel Rosalis $(55,1769)$

Natalia Ribeiro $(64,1753)$

Pedro Rodrigues da Costa $(66,1789)$

Quitéria Cardoso $(55,1769)$

Rosa da Silva $(64,1753)$

Rosa Gonçalves Soares $(51,1773)$

Rosa Maria Caldas $(71,1752)$

Rosa Maria de Carvalho (69, 1762)

Rosa Maria Teixeira $(57,1782)$

Tereza de Jesus $(47,1783)$

Tereza de Souza $(45,1796)$

Tereza dos Santos Gracia (58, 1767)

Tereza Loureira $(76,1750)$

Tereza Tavares $(64,1753)$

Ventura Alves da Costa $(68,1764)$

\section{Inventários $-1^{\circ}$ e $2^{\circ}$ Ofício (Arquivo da Casa Setecentista de Mariana).}

\section{Nome (Códice, Auto, Ano)}

Ana da Silva (44, 1018, 1781)

Ana Maria Gonçalves $(18,523,1766)$

Ana Teixeira Guimarães $(12,410,1798)$

Ângela de Souza Ferreira $(101,2105,1798)$

Antonia de Azevedo (56, 1231, 1777)

Antonia Fernandes (92, 1918, 1794)

Antonia Rodrigues Lima (101, 2104, 1776)

Antonio Alves da Silva (41, 950, 1762)

Antonio de Araújo (71, 1509, 1751)

Antonio Dias Martins (68, 1493, 1778)

Antonio Luiz (66, 1421, 1784)

Antonio Pinto Homem $(84,1815,1798)$

Arcângela do Vale $(12,419,1758)$

Catarina Correa (124, 2505, 1778)

Clara Gonçalves de Souza (76, 1619, 1783)

Diogo de Souza Coelho (103, 2141, 1774)

Esperança de Souza Barros $(120,2514,1784)$

Felipe de Godoy $(117,2336,1786)$

Joana da Costa de Meneses $(45,1018,1758)$

Joana de Carvalho da Silva $(80,1693,1774)$

Joana do Rosário (15, 465, 1750)

João de Souza Lobo $(49,1110,1771)$ 
Josefa Martins (106, 2183, 1754)

Josefa Vieira Aleluia $(80,1690,1785)$

Justa Maria Gonçalves $(82,1751,1790)$

Lourenço Fernandes, $(33,784,1788)$

Luiz Feraz Lima (33, 785, 1777)

Luiza Rodrigues (33, 773, 1763)

Manoel da Silva (94, 2024, 1759)

Manoel de Souza $(138,2792,1788)$

Mariana da Silva (122, 2456, 1755)

Nataria Ribeira Ferreira $(88,1907,1751)$

Quitéria da Costa (134, 2718, 1758)

Rita de Freitas (124, 2603, 1775)

Rosa Maria da Costa, $(92,1987,1753)$

Rosa Rodrigues dos Santos (92, 1990, 1760)

Sebastião de Queiroz Madureira (146, 3055, 1795)

Tereza Gomes de Abreu (135, 2731, 1782)

Tereza Loureiro (123, 2562, 1766)

Tereza Maria de Jesus (122, 2541, 1790)

Tereza Mina (123, 2560, 1764) 


\section{Bibliografia:}

\section{Fontes primárias impressas:}

ANTONIL, André João. Cultura e Opulência no Brasil. $3^{\mathrm{a}}$ ed. Belo Horizonte: Itatiaia; São Paulo: Edusp, 1982.

COSTA, Joaquim Ribeiro. Toponímia de Minas Gerais. Belo Horizonte: Imprensa Oficial do Estado, 1970.

CONSTITUIÇÕES primeiras do acerbispado da Bahia, feitas e ordenadas pelo ilustríssimo e reverendíssimo senhor Sebastião Monteiro da Vide bispo do dito arcesbispado, e do Conselho de sua magestade, propostas e aceitas em o synodo diocesano que o dito senhor celebrou em 12 de junho do anno 1707. São Paulo: Typografia, 2 de dezembro, 1853. Livro I, Título XIV.

LIMA JR., Augusto de. A Capitania das Minas Gerais: origens e formação. $3^{\mathrm{a}}$ Edição. Belo Horizonte: Edição do Instituto de História, Letras e Arte, 1965.

MATOS, Raimundo José da Cunha. Corografia histórica da província de Minas Gerais. Belo Horizonte: Itatiaia, 1981.

ORDENAÇÕES FILIPINAS, ordenações e leis do reino de Portugal recopiladas por mandato d'el Rei D. Felipe, o primeiro, editado por Cândido H. Mendes de Almeida. 5 vol. São Paulo: Edição Saraiva, 1960.

SILVA, Antônio de Morais e. Dicionário da Língua Portuguesa: recopilado dos vocábulos impressos até agora. Lisboa: Tipografia Lacerdina, 1813, 2 volumes.

\section{Livros, teses e artigos:}

AGUIAR, Marcos Magalhães de. “A coartação: uma singularidade mineira no sistema de alforria colonial?” Revista da SBPH, Curitiba, n. 18, 2000, p. 77-91.

- Vila Rica dos Confrades: A sociabilidade confrarial entre negros e mulatos do século XVIII. Dissertação de Mestrado, FFLCH/USP, 1993.

. Negras Minas Gerais: uma história da diáspora africana no Brasil colonial. Tese de Doutorado, FFLCH/USP, São Paulo, 1999.

ALENCASTRO, Luiz Felipe de. O trato dos viventes. Formação do Brasil no Altântico Sul. Séculos XVI e XVII. São Paulo: Companhia das Letras, 2000.

ALGRANTI, Leila Mezan. O feitor ausente; estudo sobre a escravidão urbana no Rio de Janeiro de 1808 a 1822. Petrópolis: Vozes, 1988.

ALMEIDA, Carla Maria Carvalho de. Alterações nas atividades produtivas mineiras, Mariana, 1750 a 1800. Dissertação de Mestrado, ICHF/UFF, Niterói, 1994. 
Homens ricos, homens bons: produção e hierarquização social em Minas Colonial: 1750-1822. Tese de Doutorado, ICHF/UFF, Niterói, 2001.

ANASTASIA, Carla Maria Junho e SILVA, Flávio Marcus da. "Levantamentos setecentistas mineiros”. In: FURTADO, Júnia Ferreira (org.). Diálogos Oceânicos: Minas Gerais e as novas abordagens para uma história do Império Ultramarino Português. Belo Horizonte: Editora UFMG, 2001, p.307-332.

ANDRADE, Francisco Eduardo de. Poder local e herança colonial em Mariana: faces da revolta dos “Ano da Fumaça” (1833). Termo de Mariana. Mariana: Imprensa Universitária da UFOP, 1998, p.113-125.

BACELLAR, Carlos Almeida Prado. “A escravidão miúda em São Paulo colonial”. In: SILVA, Maria Beatriz Nizza da (org.). Brasil: colonização e escravidão. Rio de Janeiro: Nova Fronteira, 1999, p.239-254.

“Agregados em casa, agregados na roça: uma discussão”. In: SILVA, Maria Beatriz Nizza da. (Org.). Sexualidade, família e religião na colonização do Brasil. Lisboa: Livros Horizonte, 2001, 187-199.

BARICKMAN, B.J. As cores do escravismo: escravistas "pretos”, "pardos”, e “cabras” no Recôncavo baiano, 1835. Revista CEDHAL (População e família), №2, 1999, p.7-59.

BARTH, Fredrik. Os grupos étnicos e suas fronteiras. In: O guru e o iniciador e outras variações antropológicas. Rio de Janeiro: Contra Capa, 2000.

BELLINI, Ligia. "Por amor e por interesse: a relação senhor-escravo em cartas de alforria". In: Reis, J. J. (org.), A escravidão e a invenção da liberdade: estudos sobre o negro no Brasil, São Paulo: Brasiliense, 1988, p.73-96.

BERBEL, Márcia Regina; MARQUESE, Rafael de Bivar. A ausência da raça: cidadania e ideologia pró-escravista nas Cortes de Lisboa e na Assembléia Constituinte do Rio de Janeito (1821-1824). Artigo originalmente apresentado à Conferência "Slavery, Engightenment, and Revolution in Colonial Brazil and Spanish América”, organizado pela Fordham University, New York, 2006.

A escravidão nas experiências constitucionais ibéricas, 1810-1824. Artigo originalmente apresentado ao Seminário Internacional "Brasil: de um Império a Outro (1750-1850)”, organizado pelo Projeto Temático Fapesp “A fundação do Estado e da Nação: Brasil c.1780-1850” no Departamento de História da FFLCH/USP em setembro de 2005.

BERGAD, Laird W. "Depois do boom: aspectos demográficos e econômicos da escravidão em Mariana, 1750-1800”. Estudos Econômicos, 24(3), Dez.1994.p. 495-525.

Escravidão e história econômica: demografia de Minas Gerais, 1720-1888. Tradução de Beatriz Sidou. Bauru, São Paulo: Edusc, 2004. 
BLACKBURN, Robin. A queda do escravismo colonial: 1776-1848. Tradução: Maria Beatriz Medina. Rio de Janeiro: Record, 2002.

BORGES, Célia Maia. Escravos e libertos nas Irmandades do Rosário: devoção e solidariedade em Minas Gerais, séculos XVIII e XIX. Juiz de Fora: Editora da UFJF, 2005.

BORREGO, Maria Aparecida de Menezes. A Teia Mercantil: negócios e poderes em São Paulo colonial (1711-1765). Tese de Doutorado, FFLCH/USP, 2006.

BOSCHI, Caio César. Os leigos e o poder. Irmandades leigas e política colonizadora em Minas Gerais. São Paulo: Ática, 1986.

BOXER, Charles R.. A Idade do Ouro no Brasil: dores de crescimento de uma sociedade colonial. Tradução de Nair Lacerda. $3^{a}$ Edição. Rio de Janeiro: Nova Fronteira, 2000.

CAMPOS, Adalgisa Arantes. “Considerações sobre a pompa fúnebre na capitania das Minas - o século XVIII”. Revista do Departamento de História, FAFICH/UFMG, nº4, 1987, p.3-24.

CANABRAVA, Alice. "Uma economia de decadência: os níveis de riqueza na capitania de São Paulo, 1765-67”. Revista Brasileira de economia, v. 26, nº4, out-dez, 1972, p.95-123.

CARRARA, Ângelo Alves. Agricultura e pecuária na Capitania de Minas Gerais, (16741807). Tese de Doutorado, UFRJ, Rio de Janeiro, 1997.

CASTRO, Hebe Maria Matos de. Das cores do silêncio: Os significados da liberdade no sudeste escravista. Rio de Janeiro: Nova Fronteira, 1998.

CHAVES, Cláudia Maria das Graças. Perfeitos Negociantes: mercadores das minas setecentistas. São Paulo: Annablume, 1999.

COSTA, Emília Viotti da. Da senzala à colônia. São Paulo: UNESP, 1966.

COSTA, Iraci del Nero da; LUNA, F. V. Vila Rica: população(1719-1826). São Paulo: IPE/USP, 1979, p. 230-238.

CUNHA, Manoela Carneiro da. "Sobre os silêncios da lei: lei costumeira e positiva nas alforrias de escravos no Brasil do século XIX”. Antropologia do Brasil: mito, história, etnicidade. São Paulo: Brasiliense, 1986.

Negros, estrangeiros: os escravos libertos e sua volta à África, São Paulo: Brasiliense, 1985.

DIAS, Maria Odila Leite da Silva. Quotidiano e poder em São Paulo no século XIX. 2a ed., São Paulo: Brasiliense, 1995.

EISENBERG, Peter L. Homens Esquecidos: escravos e trabalhadores livres no Brasil Séculos XVIII e XIX, Campinas: Editora da UNICAMP, 1989. 
ESPÍRITO SANTO, Cláudia Coimbra do. Economia da palavra: ações de almas nas Minas Setecentistas. Dissertação de Mestrado, FFLCH/USP, São Paulo, 2003.

FALCI, Miridan Britto Knox. “Alforrias de escravos: um estudo de relações sociais”. Revista da SBPH, Curitiba, n. 10, 1995, p.63-69.

FAORO, Raimundo. Os Donos do Poder: formação do patronato político brasileiro. $2^{\mathrm{a}}$ Ed., Porto Alegre: Ed. Globo; São Paulo, Ed. da Universidade de São Paulo, 1975.

FARIA, Sheila de Castro. A colônia em movimento: fortuna e família no cotidiano colonial. Rio de Janeiro: Nova Fronteira, 1998.

"Sinhás pretas: acumulação de pecúlio e transmissão de bens de mulheres forras no sudeste escravista (séc. XVIII-XIX)”. In: FRAGOSO, João (Org.). Escrito sobre História e Educação: uma homenagem a Maria Ieda Linhares. Rio de Janeiro: Mauad/SAPERJ, 2001, p.289-329.

“Mulheres forras - riqueza e estigma social”. Tempo, Rio de Janeiro, nº, p. 65-92.

FIGUEIREDO, Luciano Raposo. O avesso da memória: cotidiano e trabalho da mulher em Minas Gerais no século XVIII. Rio de Janeiro: José Olympio; Brasília, DF: Ednub, 1993.

FLORENTINO, Manolo Garcia Em costas negras: uma história do tráfico atlântico de escravos entre a África e o Rio de Janeiro: séculos XVIII e XIX São Paulo: Companhia das Letras, 1997.

"Alforrias e etnicidade no Rio de Janeiro oitocentista: notas sobre pesquisa". Topoi. Revista de História. Rio de Janeiro: Programa de Pós-Graduação em História Social da UFRJ/7 Letras, setembro 2002, n.5, p.9-40.

. "Sobre minas, crioulos e a liberdade costumeira no Rio de Janeiro, 1789-1871". In: FLORENTINO, Manolo (org.) Tráfico, cativeiro e liberdade. Rio de Janeiro, séculos VVII-XIX. Rio de Janeiro: Civilização Brasileira, p.338-366.

FONSECA, Cláudia Damasceno. Mariana, gênese e transformação de uma paisagem cultural. Dissertação (Mestrado em Geografia e Organização Humana do Espaço), Universidade Federal de Minas Gerais, Instituto de Geociências, 1995.

Des Terres Aux Villes de L'Or: Pouvoirs et territoires urbains au Minas Gerais (Brésil, XVIII ${ }^{e}$ siècle). Paris: Fundação Calouste Gulbenkian, 2003.

FRAGOSO, João Luís Ribeiro. Homens de grossa aventura: acumulação e hierarquia na praça mercantil do Rio de Janeiro (1790-1830). Rio de Janeiro: Arquivo Nacional, 1992.

FRAGOSO, João Luís Ribeiro; FLORENTINO, Manolo G. O arcaísmo como projeto: mercado atlântico, sociedade agrária e elite mercantil no Rio de Janeiro, c.1790-c.1840. Rio de Janeiro: Diadorim, 1993. 
FRANCO, M. S. de Carvalho. Homens livres na ordem escravocrata. $2^{\text {a }}$ edição. São Paulo: Editora Ática, 1977.

FURTADO, Celso. Formação econômica do Brasil. 15ª ed. São Paulo: Ed. Nacional, 1977.

FURTADO, Júnia Ferreira. Homens de Negócio: a interiorização da metrópole e do comércio nas Minas setecentistas. São Paulo: Hucitec, 1999.

Chica da Silva e o contratador de diamantes. O outro lado do mito. São Paulo: Companhia das Letras, 2003.

GEREMEK, Bronislaw. A piedade e a força: história da miséria e da caridade na Europa. Lisboa: Terramar, 1987.

GONÇALVES, Andréa Lisly. “As margens da liberdade: Alforrias em Minas do século XIX”. Revista de História LPH, n6, 1996, p.200-208.

161.

. “Coartações na Comarca de Ouro Preto”. Pós-História, Assis, V.6, 1998, p.149-

. As margens da liberdade: estudo sobre a prática de alforrias em Minas Gerais colonial e provincial. Tese de Doutorado, São Paulo, FFLCH/USP, 1999.

. "O Mapa dos negros que se capitaram e a população forra em Minas Gerais (17351750)”. Varia História, n²1, julho de 1999, p.142-155.

GORENDER, Jacob. O escravismo colonial. São Paulo: Ática, 1980.

A escravidão reabilitada. 2a Edição. São Paulo: Editora Ática, 1991.

GRAHAM, Richard. Clientelismo e política no Brasil do século XIX. Tradução de Celina Brandt. Rio de Janeiro: Editora UFRJ, 1997.

GRINBERG, Keila. Liberata: a lei da ambigüidade: as ações de liberdade na Corte de Apelação do Rio de Janeiro, século XIX. Rio de Janeiro: Relume-Dumará, 1994.

. "Reescravização, direitos e justiças no Brasil do século XIX”. In: LARA, Sílvia Hunold e MENDONÇA, Joseli Maria Nunes. (Org.) Direitos e justiças no Brasil: ensaios de história social. Campinas, SP: Editora da Unicamp, 2006, p.101-128.

GUIMARÃES, Carlos Magno; REIS, Liana Maria. “Agricultura e escravidão em Minas Gerais (1700/1750)”. Revista do Departamento de História. BH, FAFICH/UFMG, n², jun. 1986, p.7-36.

HENRY, Louis. "O levantamento dos registros paroquiais e a técnica de reconstituição de famílias”. In: MARCÍLIO, Maria Luiza. Demografia Histórica: orientações técnicas e metodológicas. São Paulo: Pioneira, 1977, (Coleção Novos Umbrais), p.41-63. 
HESPANHA, Antônio Manuel; XAVIER, Ângela. “As redes clientelares”. In: MATTOSO, José (Org). História de Portugal; o antigo regime. V4. Lisboa: Editorial Estampa, 1993, p.339-349.

HIGGINS, Kathleen J. 'Gender and the manumission of slaves in Colonial Brazil: the prospects for freedon in Sabará, Minas Gerais, 1710-1809'. Slavery and Abolition, 18:2 (agosto de 1997), p.1-29.

. "Licentious liberty" in a Brasilian gold-mining region: slavery, gender, and social control in eighteenth-century Sabará, Minas Gerais. University Park: The Pennsylvania State University Press, 1999.

HOLANDA, Sérgio Buarque de. "Metais e pedras preciosas". In: História Geral da Civilização Brasileira, A Época Colonial, Administração, Economia, Sociedade. $1^{\mathrm{a}}$ Edição. São Paulo: Difel, 1973, Tomo 1, Vol.2, p.259-310.

KARASCH, Mary Catherine. Vida do escravo no Rio de Janeiro: 1808-1850. São Paulo: Companhia das Letras, 2000.

KLEIN, Herbert S. “A demografia do tráfico atlântico de escravos para o Brasil”. Estudos Econômicos. São Paulo, 17 (2):129-149, maio/ago. 1987, p.129-149 .

LARA, Sílvia Hunold. Campos de violência: escravos e senhores na Capitania do Rio de Janeiro, 1750-1808. Rio de Janeiro: Paz e Terra, 1988.

. "Sedas, panos e balangandãs: o traje de senhoras e escravas nas cidades do Rio de Janeiro e de Salvador (século XVIII)”. In: SILVA, Maria Beatriz Nizza da (Org). Brasil: colonização e escravidão. Rio de Janeiro: Nova Fronteira, 2000, p. 177-191.

Fragmentos setecentistas: escravidão, cultura e poder na América Portuguesa. Campinas: Instituto de Filosofia e Ciências Humanas/Unicamp, Tese de Livre-Docência, 2004.

LE GOFF, Jacques. A história Nova. São Paulo: Martins Fontes, 1995.

LEWCOWICZ, Ida. "Herança e relações familiares: os pretos forros nas Minas Gerais do século XVIII”. Revista Brasileira de História. V. 9, n¹7, set.88/fev.89, p. 101-114.

LEWKOWICZ, Ida. Vida em família: caminhos da igualdade em Minas Gerais (séculos XVIII e XIX). Tese de Doutorado, FFLCH/USP, São Paulo, 1992.

LIBBY, Douglas Cole. "Novas considerações sobre a protoindustrialização mineira dos séculos XVIII e XIX”. Revista do Departamento de História. BH, FAFICH/UFMG, n9, 1989, p. 149-160.

LIMA, Lana Lage da Gama, VENÂNCIO, Renato P. “Alforrias de crianças escravas no Rio de Janeiro do século XIX”. Revista Resgate, n²2, 1991, p.26-34. 
LUNA, Francisco Vidal; COSTA, Iraci Del Nero da. A presença do elemento forro no conjunto de proprietários de escravos. Ciência e Cultura, 32: 1980, p.836-841.

LUNA, Francisco Vidal. Minas Gerais: escravos e senhores - análise da estrutura populacional e econômica de alguns centros mineratórios (1718-1804). São Paulo: Publicado para o Instituto de Pesquisas Econômicas, 1981.

MAGALHÃES, Sônia Maria de. A mesa de Mariana: produção e consumo de alimentos em Minas Gerais (1750-1850). São Paulo: Anablume/Fapesp, 2004.

MAIA, Moacir Rodrigo de Castro. 'À moda de sua terra': identidade étnica e parentesco espiritual entre escravos couranos na Mariana setecentista (1715-1750). Anais do XII Seminário sobre Economia Mineira, 2006.

MARANHO, Milena Fernandes. A opulência relativizada: significados econômicos e sociais dos níveis de vida dos habitantes da região do Planalto de Piratininga 1648-1682; Campinas, Dissertação de Mestrado, 2000.

MARQUESE, Rafael de Bivar. A dinâmica da escravidão no Brasil. Resistência, tráfico negreiro e alforrias, séculos XVII a XIX. Texto originalmente apresentado ao I Encontro entre Historiadores Colombianos e Brasileiros, promovido pelo Ibraco em Bogotá, Colômbia, em agosto de 2005.

MATTOSO, Kátia de Queirós. Ser escravo no Brasil. 3 ${ }^{a}$ Edição, São Paulo: Brasiliense, 1990.

“A propósito de cartas de alforria na Bahia, 1779-1850”. Anais de História, Marília, 4, 1972, p. 109-35.

MAUSS, Marcel. "Ensaio sobre a dádiva”. In: Sociologia e antropologia. Tradução de Paulo Neves. São Paulo: Cosac \& Naify, 2003.

MESGRAVIS, Laima. “Os aspectos estamentais da estrutura social do Brasil colônia”. Estudos Econômicos, n¹3, 1983, p. 799-811.

MÓL, Cláudia Cristina. "Entre sedas e baetas: o vestuário das mulheres alforriadas em Vila Rica”. Varia História, n³2, julho, 2004, p.176-189.

Mulheres forras: cotidiano e cultura material em Vila Rica (1750-1800). Dissertação de Mestrado, FAFICH/UFMG, Belo Horizonte, 2002.

MONTI, Carlo G. O processo da alforria; Mariana (1750-1779). Dissertação de Mestrado, História, FFLCH/USP, São Paulo, 2001.

MOTT, Luiz. “Cautelas de alforria de duas escravas na Província do Pará (1829-1846)”. Revista de História, São Paulo, 29 (I), 1976, p.263-268.

OLIVEIRA, Maria Inês Côrtes de. O liberto: o seu mundo e os outros, Salvador, 1790-1890. São Paulo: Corrupio, 1988. 
. "Viver e morrer no meio dos seus. Nações e comunidades africanas na Bahia do século XIX”. Revista USP, São Paulo (28), dez/fev. 95/96, p.175-193.

. “Quem eram os “negros da guiné”? A origem dos africanos na Bahia”. Afro-Ásia, 19/20, (1997), p. 37-73.

OLIVEIRA, Maria Luiza Ferreira de. Entre a casa e o armazém: relações sociais e experiência da urbanização. São Paulo, 1850-1900. São Paulo: Alameda, 2005.

PAIVA, Eduardo França. “Os inventários mineiros: fontes para a história colonial”. Cadernos de Filosofia e Ciências Humanas, Ano I, Nº1, outubro/93, p.26-29.

_2001. Escravidão e universo cultural na colônia - 1716-1789. Belo Horizonte: UFMG,

. Escravos e libertos nas Minas Gerais do século XVIII; estratégias de resistência através de testamentos. São Paulo: Annablume, 1995.

. Libertos no Brasil: africanos e mestiços nas Minas Gerais do século XVIII. Disponível em: http://geocities.yahoo.com.br/silvanifanni/EduardoFPaivaTextoLibertosnoBrasil.pdf.

PEDREIRA, Jorge M. "Brasil, fronteira de Portugal. Negócio, emigração e mobilidade social (séculos XVII e XVIII)”. Anais Universidade de Évora, no 8 e 9, dezembro 1998/1999.

PINHEIRO, Fernanda Aparecida Domingos Pinheiro. Confrades do Rosário: sociabilidade e identidade étnica em Mariana - Minas Gerais (1745-1820). Dissertação de Mestrado, ICHF/UFF, Niterói, 2006.

PINTO, Virgílio Noya. O ouro brasileiro e o comércio anglo-português: uma contribuição aos estudos da economia atlântica no século XVIII. São Paulo: Ed. Nacional, 1979.

PRADO JÚNIOR, Caio. Formação do Brasil contemporâneo. São Paulo: Brasiliense, 1942.

REGINALDO, Lucilene. Os Rosários dos Angolas: irmandades negras, experiências escravas e identidades africanas na Bahia setecentista. Tese de doutorado, . IFCH/Unicamp, Campinas, 2005.

REIS, João José. Identidade e diversidade étnicas nas irmandades negras no tempo da escravidão. Tempo, vol. 2, n³, 1996, p. 7-33.

RIBEIRO, Núbia Braga. Cotidiano e liberdade: um estudo sobre os alforriados em Minas no século XVIII. 208p. Dissertação de Mestrado, FFLCH/USP, São Paulo, 1996.

RUSSELL-WOOD, A. J R. “Através de um prisma africano: uma nova abordagem ao estudo da diáspora africana no Brasil colonial”. Tempo, 12, 2001, p. 11-50. 
'Acts of Grace': Portuguese Monarchs and Their Subjacts of African Descent in Eighteenth-Century Brazil. Journal of Latin América Studies, Vol. 32, No.2, Maio 2000. p. 307-332.

.. "O Governo Local na América Portuguesa: um estudo de divergência cultural”. Revista de História, São Paulo, nº109, v.50, 1997, 25-79.

2005.

Escravos e libertos no Brasil colonial. Rio de Janeiro: Civilização Brasileira,

SAMPAIO, Antônio Carlos Jucá de. "Crédito e circulação monetária na colônia: o caso fluminense, 1650-1750”. Anais do V Congresso Brasileiro de História Econômica. Belo Horizonte, ABPHE, 2003.

. Na encruzilhada do império: hierarquias sociais e conjunturas econômicas no Rio de Janeiro (c.1650-c.1750). Rio de Janeiro: Arquivo Nacional, 2003.

SANTOS, Raphael Freitas. "Devo que pagarei”: sociedade, mercado e práticas creditícias na Comarca do Rio das Velhas - 1713-1773. Dissertação de Mestrado, FAFICH/UFMG, Belo Horizonte, 2005.

SCARANO, Julita. Devoção e escravidão. A Irmandade de Nossa Senhora do Rosário dos Pretos no Distrito Diamantino no século XVIII. São Paulo: Nacional-Coleção Brasiliana, 1976.

SCHWARTZ, Stuart B. Burocracia e sociedade no Brasil colonial. São Paulo: Ed. Perspectiva, 1979.

Escravos, roceiros e rebeldes. Tradução: Jussara Simões. Bauru, São Paulo: EDUSC, 2001.

SILVA, Flávio Marcus da. "Estratégias de mercado e abastecimento alimentar em Minas Gerais no século XVIII”. Anais do IX Seminário de Economia Mineira 2000.

SILVA, Luiz Geraldo. "Da festa à sedição. Sociabilidades, etnia e controle social na América Portuguesa (1776-1814)”. In: JANCSÓ, István; KANTOR, Íris (orgs.). Festa: Cultura \& Sociabilidade na América Portuguesa. São Paulo: Hucitec: Editora da Universidade de São Paulo: Fapesp: Imprensa Oficial, volume I, 2001, p.313-335.

SILVA, Maria Beatriz Nizza da. “A luta pela alforria”. In: SILVA, Maria Beatriz Nizza da. (Org.). Brasil: colonização e escravidão. Rio de Janeiro: Nova Fronteira, 1999, p.296-307.

"Pobreza feminina no Brasil colonial”. Revista de Ciências Históricas, Universidade Portucalense, Vol. XI, 1996, p.91-100.

SILVA, Marilda Santana da. Dignidade e transgressão: mulheres no Tribunal Eclesiástico em Minas Gerais (1748-1830). Campinas: Editora da Unicamp, 2001.

SILVA, Marilene Rosa Nogueira. Negro na rua. São Paulo: Hucitec, 1988. 
SILVEIRA, Marco Antônio. O universo do indistinto. Estado e sociedade nas Minas Setecentistas (1735-1808). São Paulo: Hucitec, 1997.

SIMONSEN, Roberto C. História Econômica do Brasil. 1500-1820. São Paulo: Companhia Editora Nacional, Coleção Brasiliana, 1969.

SOARES, Carlos Eugênio Líbano. Capoeira escrava e outras tradições rebeldes no Rio de Janeiro (1808-1850). Unicamp: Ed. Da Unicamp, 2001.

SOARES, Lucas Jannoni. Presença dos homens livres pobres na sociedade colonial na América Portuguesa, São Paulo (1765-1775). Dissertação de Mestrado, FFLCH/USP, São Paulo, 2005.

SOARES, Márcio de Sousa. A remissão do cativeiro: alforrias e liberdades nos Campos dos Goitacazes, c.1750 - c.1830. Doutorado em História, ICHF/UFF, Niterói, 2006.

SOARES, Márcio de Souza. "A dádiva da alforria e o governo dos escravos no Brasil colonial (Campos dos Goitacazes, c. 1750 - c. 1830)”. LPH - Revista de História. V.01, n.1. Mariana: Departamento de História, UFOP, 2004-2005, p.11-34.

SOARES, Mariza de Carvalho. “A 'nação' que se tem e a 'terra' de onde se vem: categorias de inserção social de africanos no Império português, século XVIII”. Estudos AfroAsiáticos, Ano 26, n²6, 2004, p.303-330.

. “Descobrindo a Guiné no Brasil colonial”. RIHGB, Rio de Janeiro, 161(407) 7194, abr./jun. 2000, p. 71-94.

SOUZA, Elizabeth Valéria Rouwe de; SOUZA, Marcos Aurélio Rouwe de. "Reconhecimento dos autos de exames de cadáveres”. In: GONÇALVES, Andréa Lisly, OLIVEIRA, Ronald Polito. (Org.). Termo de Mariana: história e documentação. Mariana: Imprensa Universitária da UFOP, Volume II, 2004, p.189-191.

SOUZA, Laura de Mello e. Desclassificados do ouro: a pobreza mineira no século XVIII. Rio de Janeiro: Graal, 1982.

. Norma e conflito: aspectos da História de Minas no século XVIII. Belo Horizonte: Editora UFMG, 1999.

"Coartação - problemática e episódios referentes a Minas Gerais no século XVIII”. In: SILVA, Maria Beatriz Nizza da. (Org.). Brasil: colonização e escravidão. Rio de Janeiro: Nova Fronteira, 1999, p.275-295.

VENÂNCIO, Renato Pinto. "Estrutura do Senado da Câmara”. Termo de Mariana: história e documentação. Mariana: Imprensa Universitária da UFOP, 1998, p 139-141.

“Pobreza carioca: uma proposta de avaliação quantitativa, 1750-1808”. Comunicação apresentada no II Seminário de História Quantitativa e Serial, IPEA/PUC/NEASPOC, Belo Horizonte, 2001. 
WEHLING, Arno; WEHLING, Maria José. Direito e Justiça no Brasil Colonial: O Tribunal da Relação do Rio de Janeiro (1751-1808). Rio de Janeiro: Renovar, 2004.

ZEMELLA, Mafalda P. O abastecimento da capitania das Minas Gerais no século XVIII. $2^{a}$ ed. São Paulo: Hucitec: Editora da Universidade de São Paulo, 1999. 